\author{
UNIVERSIDADE DE SÃO PAULO \\ ESCOLA DE COMUNICAÇÕES E ARTES \\ DEPARTAMENTO DE COMUNICAÇÕES E ARTES
}

Linguagens da Comunicação: jornalismo e publicidade no Ensino Fundamental de Barueri/SP

ELISANGELA RODRIGUES DA COSTA

São Paulo

Agosto - 2012 


\section{Linguagens da Comunicação: jornalismo e publicidade no Ensino Fundamental de Barueri/SP}

Dissertação apresentada ao Programa de PósGraduação em Ciências da Comunicação, área de concentração Interfaces Sociais da Comunicação, linha de pesquisa Comunicação e Educação, da Escola de Comunicações e Artes da Universidade de São Paulo, como exigência para a obtenção do título de Mestre em Ciências da Comunicação, sob a orientação do Prof. Dr. Adilson Odair Citelli.

São Paulo

Agosto - 2012 
Autorizo a reprodução e divulgação total ou parcial deste trabalho, por qualquer meio, convencional ou eletrônico, para fins de estudo e pesquisa desde que citada a fonte.

\section{Catalogação na publicação \\ Serviço de Biblioteca e Documentação Escola de Comunicações e Artes da Universidade de São Paulo}

Costa, Elisangela Rodrigues da

Linguagens da comunicação: jornalismo e publicidade no ensino fundamental de Barueri/SP - São Paulo: E.R. Costa, 2012.

$207 \mathrm{p}$.

Dissertação (Mestrado) -- Escola de Comunicações e Artes / Universidade São Paulo.

Orientadora: Adilson Odoir Citelli

1. Comunicação. 2. Linguagem. 3. Meditação. 4. Professor. 5. Educação

I. Citeli, Adilson Odair. I. Título

CDD 21.ed. - 
A dissertação Linguagens da Comunicação: jornalismo e publicidade no Ensino Fundamental de Barueri/SP realizada por Elisangela Rodrigues da Costa, mestranda do Programa de Pós-Graduação em Ciências da Comunicação da Escola de Comunicações e Artes da Universidade de São Paulo, foi em exame de Defesa realizada no dia de de 2012, pela banca composta por:

Prof.(a) Dr.(a):

Instituição: Assinatura:

Prof.(a) Dr.(a):

Instituição: Assinatura:

Prof.(a) Dr.(a):

Instituição: Assinatura: 


\section{AGRADECIMENTOS}

Ao que chamarei de meu eterno orientador, professor Dr. Adilson Odair Citelli, pelos direcionamentos fundamentais durante todo o processo de pesquisa, pela paciência e confiança em meu projeto. Um professor e pesquisador na acepção das palavras, por quem nutro profunda admiração.

Aos professores de Língua Portuguesa e gestores do Ensino Fundamental da rede municipal de Barueri, pelas valiosas contribuições e acolhimento da pesquisa.

À Coordenadora do Ensino Fundamental do município de Barueri, Flávia Cristina Moreno, amiga, chefe, que compreendeu os meandros do Mestrado.

Às supervisoras de ensino da rede municipal de Barueri Tânia Zicardi Nardini, Gênia Miekusz, Rosália Martins Ribeiro, pelo entendimento e reconhecimento da importância do pesquisador na rede de ensino.

Aos meus pais Maria José e José Maria, pelo incentivo e apoio constante em minha vida acadêmica.

À minha única irmã, Eliana, e ao meu cunhado, Luiz Henrique, pela compreensão nos momentos de distanciamento.

Aos queridos colegas Rogério Pelizzari e Cláudio Messias, pelo incentivo, acolhida e torcida pela entrada no Mestrado.

Aos meus colegas e amigos que formam o nosso grupo de estudos: Eliana Nagamini, Ana Luísa Zaniboni Gomes, Maria do Carmo Souza Almeida, Michel Carvalho, Sandra Pereira Falcão e Helena Corazza.

Aos meus colegas de trabalho: Flávia Garcia Teodorelli Campos, Quitéria Aluoiso Pinheiro, Mariana Fernandes Alves, José Fábio da Silva, que por diversos momentos compartilharam de minhas angústias e desafios. 
Ao professor Dr. Belarmino César Guimarães Costa, sempre me acompanhando e contribuindo para minhas indagações e pesquisas, um excelente professor e amigo.

À professora Dra. Maria Immacolata Vassallo de Lopes, a quem admiro e respeito, pelo esforço em nos mostrar o caminho da pesquisa e, sobretudo, o papel do pesquisador.

À minha amiga irmã Aparecida Pennacchioni, pelo apoio, paciência e entendimento do significado do Mestrado em minha vida.

Ao meu amigo, irmão, Ricardo Nascimento, pelo incentivo de realizar a pesquisa.

À amiga Sônia Aparecida Bruno, coordenadora pedagógica da EMEF Armando Cavazza.

Ao professor Dr. Ismar de Oliveira Soares, pelos apontamentos e análises acerca da Educomunicação e por ampliar meu entendimento da área.

À revisora desta dissertação, Ana Paula Hachich de Souza, pelos fins de semana e noites afora em prol das correções textuais da pesquisa. 


\section{RESUMO}

COSTA, E. R. Linguagens da Comunicação: jornalismo e publicidade no Ensino Fundamental de Barueri/SP. 2012. 207 f. Dissertação (Mestrado) - Escola de Comunicações e Artes, Universidade de São Paulo, São Paulo, 2012.

A diversidade de linguagens, em consonância com os recursos tecnológicos disponíveis atualmente, marca a primeira década do século XXI. Em decorrência deste processo, houve mudanças nos modos de emissão e recepção de mensagens, que foram para além da Comunicação e adentraram a Educação. Sendo assim, no cenário contemporâneo a escola é o local que reflete as idiossincrasias sociais quanto à utilização dos aparatos midiáticos.

A incorporação das linguagens comunicacionais no referido contexto torna-se, cada vez mais, um processo naturalizado, no qual o docente tem uma importante função, sobretudo o especialista em Língua Portuguesa. Afinal, cabe a este profissional a execução de ações pedagógicas voltadas à aquisição das habilidades de leitura e escrita e, consequentemente, das capacidades de argumentar e interpretar, competências imprescindíveis para os alunos como forma de garantir a autonomia destes cidadãos em todos os aspectos da vida profissional e pessoal.

O papel de mediação que os meios de comunicação, os dispositivos e, principalmente, os educadores adquirem neste processo é fundamental para a orientação dos jovens incorporados ao mundo digital. Por admitir a relevância destes profissionais, determinamos como foco da investigação a opinião do educador especialista de Língua Portuguesa sobre o entendimento quanto à utilização de instâncias midiáticas no ambiente escolar.

Com este fundamento, verificamos como os professores de Língua Portuguesa do município de Barueri, região metropolitana de São Paulo, utilizam as linguagens do jornalismo e da publicidade, como compreendem a inter-relação comunicação e educação perante as exigências do atendimento do aluno adolescente dos anos finais ( $8^{\circ}$ e $9^{\circ}$ anos) do Ensino Fundamental.

Diante de tais questionamentos, a pesquisa examina o seguinte problema: como as linguagens da comunicação das esferas jornalística e publicitária são legitimadas na prática dos docentes de Língua Portuguesa de Barueri nos anos finais do Ensino Fundamental?

As reflexões teóricas fundamentadas na perspectiva dos Estudos Culturais perpassam aspectos conceituais que, em diálogos com o objeto empírico, consideram o processo da interface entre Comunicação e Educação. O modelo metodológico adotado é o proposto por Maria 
Immacolata Vassallo de Lopes, com base na reflexão, por meio das seguintes técnicas: observação indireta, questionários e entrevistas.

PALAVRAS-CHAVE: Comunicação; Linguagem; Mediação; Professor; Educação. 


\begin{abstract}
COSTA, E. R. Languages of communication: journalism and advertising in elementary education in Barueri/SP. 2012. 207 f. Dissertação (Mestrado) - Escola de Comunicações e Artes, Universidade de São Paulo, São Paulo, 2012.
\end{abstract}

The diversity of languages, in line with the technological resources available today, marks the first decade of this century. As a result of this process, there were changes in the modes of transmission and reception of messages, which were beyond entered the Communication and Education. Thus, in the contemporary scene is the local school, which reflects the idiosyncrasies in the use of social media apparatuses.

The incorporation of language communication in that context becomes, increasingly, a natural process in which the teacher has an important function, especially the specialist in Portuguese. After all, it's up to the execution of this professional pedagogical actions aimed at acquiring the skills of reading and writing and, consequently, the ability of interpretation and argumentation skills essential for students in order to guarantee the autonomy of citizens in all aspects of life professional and personal.

The important role of mediation that the media, devices, and especially educators acquire in this process is critical to guiding young people incorporated into the digital world. By admitting the relevance of these professionals, we determined the focus of investigation to understand the educator expert in the area into consideration and use of media bodies in the school environment.

With this foundation, we examine how teachers of Portuguese in the city of Barueri, metropolitan region of São Paulo, using the language of journalism and advertising, as they understand the interrelationship communication and education to the demands of the student's attendance of teen final cycles (8 and 9 years) Elementary School.

Given these questions, the research examines the following problem: how languages of communication in journalism and advertising spheres are legitimized the practice of teachers of Portuguese Barueri in the final years of elementary school?

The theoretical reflections based on the perspective of cultural studies conceptual issues that underlie, in dialogue with the empirical object, consider the process of interface between communication and education. The methodological model adopted is that proposed by Maria Immacolata Vassallo de Lopes, based on reflection, through the following techniques: indirect observation, questionnaires and interviews. 
KEYWORDS: Communication, Language, Mediation, Professor, Education. 


\section{SUMÁRIO}

INTRODUÇÃO ...................................................................................................................... 14

1 A DEFINIÇÃO DO OBJETO ......................................................................................................18

1.1 A construção do objeto ..................................................................................................................19

1.2 Justificativa da escolha do tema ..............................................................................................21

1.3 Formulação do problema ...............................................................................................................29

1.4 Objetivos da pesquisa..................................................................................................30

2 QUADRO TEÓRICO DE REFERÊNCIA _.........................................................................32

2.1 As teorias sustentadoras: da Cultura à interface comunicação/educação .....................32

2.2 Estudos Culturais: diálogos com a Comunicação..............................................................33

2.3 As configurações do contexto (pós) moderno .........................................................................36

2.4 A condição comunicativa contemporânea ..............................................................................38

2.5 As mediações no processo comunicacional........................................................................41

2.5.1 Mediação tecnológica: as novas alfabetizações...................................................................44

2.5.2 Mediações sociais: dos nativos aos imigrantes digitais......................................................46

2.5.3 Das mediações ao estudo da língua .......................................................................................48

2.6 Língua Portuguesa: redefinição dos Parâmetros Curriculares Nacionais....................49

2.6.1 Linguagem e gênero: conceitos direcionadores ................................................................50

2.6.2 Os gêneros na escola ......................................................................................................................53

2.6.3. Os gêneros digitais...........................................................................................................57

2.7 Comunicação: do mundo da notícia ao universo imagético da publicidade ..................58

2.7.1. Na escola: dos gêneros à produção jornalística ................................................................66

2.7.2. Composição, códigos e imagens na linguagem publicitária em sala de aula............71

2.8 Mídia e modelo escolar: em tempos de convergência............................................................75

2.9 A prática pedagógica emancipadora ......................................................................................... 78 
2.10 Comunicação e Educação: da interface à educomunicação no contexto escolar.......83

2.11 A ordem discursiva: hierarquia, coerção e exclusão .......................................................89

2.12 O encaminhar da pesquisa: contextos de Barueri ........................................................93

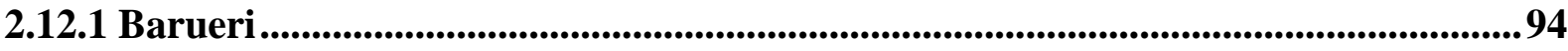

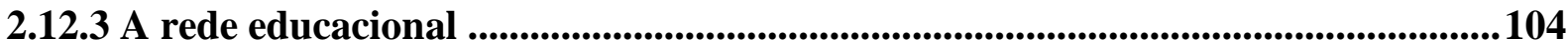

2.12.4 O docente de Língua Portuguesa ....................................................................105

2.12.5 Os conteúdos e planos da área .....................................................................................................106

2.12.6 Proposta Curricular no Ensino Fundamental .....................................................106

2.12.7 As novas tecnologias na escola na Proposta Curricular de Língua Portuguesa (LP)

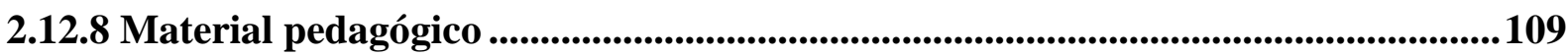

2.12.9 A avaliação externa como quesito de qualidade .......................................................110

2.12.10 A avaliação mensal in loco ..................................................................................110

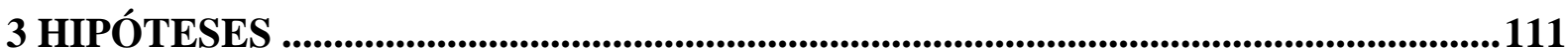

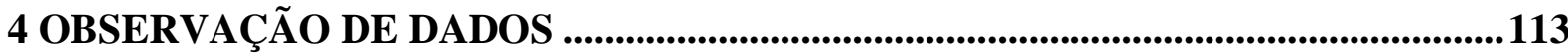

4.1. Observação ..........................................................................................................................113

4.1.1 A amostragem .............................................................................................................113

4.2. As técnicas de coleta de dados ........................................................................................115

4.3. Relato sobre a coleta de dados......................................................................................117

5 A DESCRIÇÃO DE DADOS.....................................................................................119

6 A INTERPRETAÇÃO DOS DADOS ....................................................................139

6.1 Linguagens da comunicação e adolescentes: os desafios da docência ........................141

6.2 O jornalismo e a publicidade em Língua Portuguesa ...............................................145

6.3 Os porquês da comunicação no uso pedagógico ......................................................... 150

6.4 As implicações do material pedagógico no uso dos gêneros midiáticos.....................153

6.5 Infraestrutura e recursos tecnológicos .............................................................................157

6.6 Interface, formação continuada e currículo ........................................................161 


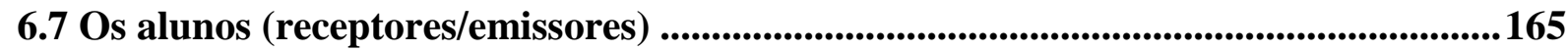

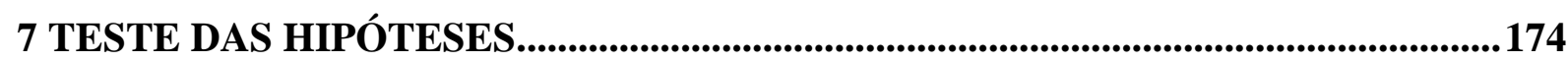

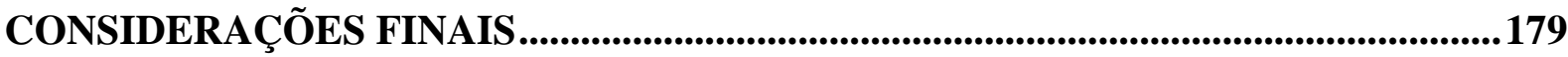

REFERÊNCIAS BIBLIOGRÁFICAS ........................................................................... 185

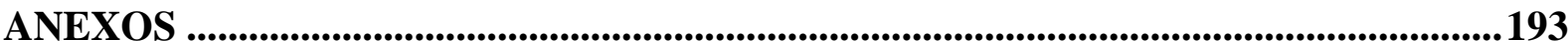


A tradição dos oprimidos nos ensina que o estado de exceção em que vivemos é na verdade regra geral. Precisamos construir um conceito de história que corresponda a essa verdade. Nesse momento, perceberemos que nossa tarefa é criar um verdadeiro estado de emergência.

Walter Benjamin 


\section{INTRODUÇÃO}

O novo valor atribuído ao transitório, ao fugidio $e$ ao efêmero, a própria celebração do dinamismo, revela um anseio por um presente estável, imaculado e não corrompido.

(Jürgen Habermas apud Harvey 1989)

Esta dissertação de Mestrado abarca uma parcela do trabalho realizado ao longo do curso de Pós-graduação em Ciências da Comunicação, sendo formada também pelas experiências construídas a partir de trocas com os colegas e professores e em consonância com a pesquisa feita in loco. O texto produzido representa a "ponta do iceberg", no sentido de algo que aparenta ser de simples compreensão, mas, se melhor analisado, apresenta complexidade que demanda inúmeras atenções, se comparadas às iniciais evidentes. Neste sentido, o trabalho que apresentamos a seguir configura os conhecimentos acumulados durante a estadia acadêmica: da vivência em sala de aula, perpassando congressos e discussões grupais, até a elaboração de conteúdo para a publicação desta dissertação.

Em nossa jornada discente, o Mestrado, sem dúvida, foi uma das experiências mais ricas e importantes, um verdadeiro trabalho na acepção da palavra. No entanto, é válido salientar, um caminho árduo marcado por exercícios de paciência, leituras, dúvidas, reflexões e aprendizados. Fato que não invalida a gratificação de tê-lo percorrido, embora, intimamente, persista a sensação de que poderíamos ter feito mais do que fizemos.

O adentrar no universo da pesquisa, tanto por meio do embasamento teórico quanto da fixação de uma organização pessoal, permitiu-nos a compreensão de que um estudo científico é muito maior que teorias e métodos; neste ínterim, acreditamos ser impossível o não envolvimento com o objeto de pesquisa. Ainda que em determinados momentos recorrêssemos ao distanciamento para a visualização do todo, este procedimento não impediu nossa aproximação, obviamente mantendo o rigor epistemológico e metodológico necessário.

A racionalidade atribuída às ciências encontra-se, de certo modo, com a fragilidade humana durante o processo construtivo da pesquisa, impedindo que se ignore a sensibilidade e os sentimentos. Neste aspecto, os meios de comunicação aproximam as pessoas, sobretudo as mais jovens, porque facilitam o estabelecimento das relações sociais e são determinantes em suas ações cotidianas.

A entrada das tecnologias em espaços de educação formal e o desenvolvimento das mídias resultaram em novas maneiras de produção, mediação e recepção do conhecimento. 
Neste contexto, os meios de comunicação são estratégicos nas reconfigurações sociais, "obrigando" a incorporação de suas linguagens no espaço escolar, também como alternativa de aproximação com os alunos, para auxiliá-los no processo de articulação dos conteúdos informacionais de diferentes fluxos.

Então, propomo-nos, nesta pesquisa, a analisar como se constrói a inter-relação dos campos da comunicação e educação, sob a perspectiva comunicacional. Neste direcionamento, durante a elaboração de nosso conteúdo teórico, defendemos que a produção de sentido está, cada vez mais, sendo alterada na atual organização social - com base no paradigma da convergência, dos variados suportes, ambientes, e, ainda, na amplitude do mundo digital.

A condição contemporânea exige a adoção dos processos comunicacionais em espaços diversos, na medida em que não é mais possível pensar em sociedade sem a incorporação de recursos tecnológicos; com isto, locais que antes priorizavam apenas uma característica são invadidos por dispositivos e informações que circulam por meio de uma infinidade de mediações, alterando a sua finalidade inicial, caso da escola.

$\mathrm{Na}$ referida instituição, os textos do jornalismo e publicidade materializam as características desta época com mensagens fortemente marcadas por símbolos, imagens, fontes audiovisuais, em uma sincronia que concorre com os saberes ditos institucionais.

O caráter sócio-histórico revela que as práticas escolares assumiram diversos papéis ao longo do tempo. Atualmente, os maiores desafios se encontram na relação entre o ensino formal, público, e a comunicação, implicando em ações didático-pedagógicas complexas e conflituosas, ancoradas, dependentes dos sujeitos mediadores deste processo: os professores.

Defendemos que tanto a linguagem jornalística como a publicitária reúnem o minimalismo em relação ao uso da escrita, representação do real, intervenções iconográficas, marcantes no perfil das novas gerações, sobretudo dos adolescentes dos anos finais do Ensino Fundamental.

Desta maneira, a incorporação destas no contexto educacional torna-se imprescindível e o especialista de Língua Portuguesa, sujeito de nossa pesquisa, assume função importante, justificando a seleção destes docentes em nossa investigação, analisados por meio das técnicas de questionários e entrevistas.

Entendemos que o contexto é relevante para a investigação, pois é parte do universo no qual os sujeitos pesquisados estão inseridos, o que justifica a referência ao município no título da dissertação. Situado na região metropolitana da Grande São Paulo, a 26 km da 
capital, Barueri tem uma economia baseada na arrecadação de impostos, em especial o proveniente da prestação de serviços (ISS).

A Federação das Indústrias do Rio de Janeiro (FIRJAN) divulgou uma pesquisa sobre desenvolvimento de municípios, edição 2011, na qual classifica Barueri em primeiro lugar entre 5.564 municípios brasileiros analisados. O chamado Índice Firjan de Desenvolvimento Municipal (IFDM) é determinado pela análise de três áreas: Educação, Saúde e Emprego e Renda. De acordo com o site oficial da FIRJAN, "os dados revelam que a cidade possui um histórico de desenvolvimento que a classifica, desde a primeira edição do índice em 2005, entre as dez melhores do país"1.

O município é conhecido por abrigar o bairro de Alphaville, nos limites entre Barueri e Santana do Parnaíba. Segundo dados do IBGE de $2010^{2}$, sua população é de 240 mil habitantes e, destes, cerca de 50 mil residem no referido bairro, que possui 12 condomínios residenciais fechados de alto padrão e é sede de escritórios de multinacionais (Centros Comerciais e Empresariais) geradores de impostos que subsidiam em grande parte o município.

Com a explanação introdutória, consideramos importante o acréscimo do percurso desta investigação, que está dividida em sete capítulos e direcionada na orientação metodológica proposta por Maria Immacolata Vassallo de Lopes.

No capítulo I, definimos o objeto, desde o processo construtivo, justificativa da escolha do tema, formulação e definição do problema e os objetivos propostos. Em seguida, no capítulo II, expomos as bases teóricas que sustentam a pesquisa, estabelecendo diálogos com os autores que embasam nosso estudo, principalmente Adilson Citelli, Guillermo Orozco Gómez, Jésus Martín-Barbero, Moacir Gadotti, Paulo Freire, Mikhail Bakhtin, Helena Brandão, Maria Aparecida Baccega e Mauro Wilton de Sousa. Iniciamos este tópico apresentando o entendimento da condição comunicativa contemporânea, considerando os contextos sócio-históricos, as relações entre as linguagens do jornalismo e publicidade no ambiente de educação formal pública municipal e os sujeitos destes processos - os professores e alunos, e os encontros com um ensino que priorize a autonomia dos indivíduos. Trilhamos um caminho a partir da Comunicação até sua interface com a Educação.

\footnotetext{
${ }^{1}$ Federação das Indústrias do Rio de Janeiro. Análise Especial - São Paulo IDFM/Ano 4. Edição 2011 - Ano base 2009. p. 3.

Disponível em: 〈http://www.firjan.org.br/IFDM/download/IFDM2009_Analise_Especial_SP.pdf〉. Acesso em 30 de maio de 2012.

${ }^{2}$ Censo 2010 (IBGE). Disponível em: <http://www.censo2010.ibge.gov.br/sinopse/index.php?uf=35\&dados=0>. Acesso em 30 de maio de 2012.
} 
Para o capítulo III, definimos o sistema de hipóteses, as afirmações com a intenção de orientar a pesquisa, as quais podem ser confirmadas ou rejeitadas ao término da investigação. No capítulo IV, ocorre o processo de observação de dados, onde apresentamos a amostragem, as técnicas de coleta e nossos relatos sobre o fato de irmos a campo, propriamente dito. $\mathrm{O}$ capítulo V, por sua vez, apresenta a descrição dos dados e as tabulações acerca da prática docente com os textos jornalísticos e publicitários no Ensino Fundamental. E a fase mais importante da investigação, o capítulo VI, a interpretação dos dados, o momento em que o objeto teórico e empírico se unem, proporcionando a análise em condição científica. Com ela, procedemos aos testes das hipóteses, capítulo VII, para então finalizarmos o trabalho. 


\section{A DEFINIÇÃO DO OBJETO}

Realizamos uma pesquisa empírica acerca da interface entre comunicação e educação, verificando como as linguagens da comunicação - jornalística e publicitária - estão atreladas à prática pedagógica dos docentes de Língua Portuguesa frente a discentes com idades aproximadas de 13 a 15 anos matriculados nos últimos anos do ciclo final do Ensino Fundamental em Barueri.

O processo investigativo se pautou, entre outros itens, nas relações deste professor com as mídias, sua percepção diante do contexto local quanto à inter-relação entre comunicação e educação, bem como na sua interpretação das novas formas de construção dos sentidos, proporcionadas pelos diálogos entre essas linguagens.

A proposta metodológica utilizada é de Maria Immacolata Vassallo de Lopes, exposta em Pesquisa em Comunicação (2005), cujas referências primordiais são: a reflexão do método, em parceria com o processo investigativo, com vistas ao despertar de uma atitude crítica do pesquisador. A opção pela aplicação deste modelo foi feita pelo dinamismo que apresenta, tanto do ponto de vista estrutural quanto do processo em si, permitindo configurações do tipo "vertical” (níveis, instâncias - como discurso científico) e "horizontal" (fases da investigação - prática).

De acordo com Lopes, a metodologia propriamente dita é uma construção estruturada em níveis e fases, tecida concomitantemente à prática do trabalho, pressupondo, assim, a inexistência de fórmulas prontas e fixas para o percurso da pesquisa. Para a autora, o caminho não é dado de imediato; pelo contrário, ele se constrói e reconstrói, justificando o prérequisito de uma visão linear, e não automática, das operações como fundamento importante. Visto dessa maneira, o campo investigativo permite interpenetrações de diversas instâncias do objeto e voltas constantes entre as dinâmicas envolvidas em suas etapas.

Lopes demonstra ainda os equívocos que podem ser evitados com a adoção dessa concepção metodológica: "uma discussão formal e abstrata das questões epistemológicas, teóricas, metódicas e técnicas (...) e uma visão linear da pesquisa, responsável pela redução desta a um processo estandartizado e automático de operações” (2005:98). 


\subsection{A construção do objeto}

A assertiva de que numa pesquisa o objeto é "construído, conquistado e comprovado", de Gaston Bachelard, legitimada por Pierre Bourdieu e por Lopes, ratifica a noção da elaboração processual e diligente. É neste sentido que: “defender juntamente com Bachelard que o fato científico é conquistado, construído e constatado é recusar, ao mesmo tempo, o empirismo que reduz o ato científico a uma constatação e o convencionalismo que lhe opõe somente condições prévias da construção" (BOURDIEU, 1999:22).

No pensamento de Bourdieu, a conquista ocorre por rupturas nas quais o pesquisador, por meio de observações, transpassa a visão do senso comum e inicia a construção do seu objeto, a partir da organização de conceitos e da busca por comprovação, obtida por meio de testes, para fomentar o conhecimento.

A partir deste ponto, iniciamos a chamada vigilância epistemológica, que inclui a concepção de um investigador crítico, questionador, com foco em seu problema. O conceito em si, da forma proposta por Bachelard, traduz, em seu raciocínio, o rompimento do estudo com o saber imediato, de sentido superficial, além de também desfazer as chamadas "noções prévias".

Lopes, ao abordar a questão da problemática, afirma em outra obra que "aqui se coloca a indagação sobre a já mencionada relevância social do objeto de estudo" e vai adiante sobre a preocupação com a pesquisa de comunicação, em países latinos, refletindo sobre "quais as perguntas que devem ser feitas, quanto à pesquisa, em nossos países latino-americanos?"; a autora mesma sugere: "aquelas que a ciência não pode responder, porque são valorativas, dependentes de uma concepção de mundo do pesquisador” (2004:28).

Neste momento, em breve relato discorro sobre o processo construtivo de meu objeto ${ }^{3}$. Em 1996, ainda residente em Tatuí, no interior de São Paulo, no último ano do curso de Magistério (Ensino Médio), que me habilitou à docência na Educação Infantil e no primeiro ciclo (hoje, o Ensino Fundamental I é composto de cinco anos, do $1^{\circ}$ ao $5^{\circ}$ ) do Ensino Fundamental, prestei vestibular e ingressei na Universidade Metodista de Piracicaba, no curso de Comunicação Social - habilitação em Jornalismo. Para custear a graduação, consegui algumas aulas de Língua Portuguesa na rede estadual de São Paulo e concomitantemente trabalhava para alguns jornais impressos da região.

\footnotetext{
${ }^{3} \mathrm{O}$ relato da justificativa de escolha do objeto, nesta primeira parte, será na $1^{\mathrm{a}}$ pessoa do singular para dar o destaque necessário aos motivos que direcionaram a construção da pesquisa.
} 
Em 2000, assim que conclui o Ensino Superior, mudei para o município de Barueri e fiz uma especialização em Sociologia e Política na Fundação de Sociologia e Política de São Paulo (FSPSP) - tradicional pelo método americano da Escola de Chicago e pelos estudos de Florestan Fernandes.

Em seguida, em 2002, consegui emprego em um jornal especializado em Educação. Após três meses de atuação, recebi uma proposta para coordenar pedagogicamente uma escola da rede municipal e prossegui paralelamente como freelancer no jornalismo.

Passados três anos na escola, recebi outra proposta, desta vez para elaborar material pedagógico de Língua Portuguesa na rede municipal de Barueri aos alunos do Ensino Fundamental II. Durante quatro anos, trabalhei em uma equipe de autores destes conteúdos dentre os quais era a única jornalista - os demais eram professores especialistas da área.

Começaram, então, os meus questionamentos, pois, apesar de ter sido Coordenadora Pedagógica, era vista pelo grupo como "comunicadora"; principalmente em virtude das propostas que eu defendia, sempre relacionadas à comunicação, esse era o olhar que prevalecia sobre o meu trabalho, o de "jornalista". Mas, o que ainda me incomodava eram os desafios para discutir e incluir as linguagens da comunicação na composição deste material. Naquele grupo de elaboradores, as linguagens comunicacionais não eram consideradas tão importantes para um trabalho sistemático. Na ótica dos especialistas do grupo, elas eram entendidas como "instrumentos" e "acessórios" para a prática em sala de aula, de caráter opcional.

Diante dessas constatações, percebi que era necessário ingressar em uma nova graduação e, por já estar envolvida na área, escolhi o curso de Pedagogia. Foi justamente neste momento, ao aprofundar minha observação sobre a educação, que vislumbrei a necessidade de interface entre as duas áreas. Também foi quando encontrei as referências dos livros do professor Adilson Odair Citelli acerca do assunto.

A partir desse momento, em 2008, resolvi ser "aluna ouvinte" do professor Adilson Citelli e em 2009 me tornei "aluna especial", ano em que assumi outra função na Secretaria Municipal de Educação de Barueri, agora de Coordenadora dos Cursos de Formação Continuada, a serviço do Centro de Aperfeiçoamento de Professores (CAP).

Ingressei no mestrado em 2010, na linha de pesquisa Comunicação e Educação, como orientanda do professor Doutor Adilson Odair Citelli, com a proposta de desenvolver uma pesquisa empírica acerca das linguagens da comunicação junto aos professores de Língua Portuguesa nos anos finais ( $8^{\circ}$ e $9^{\circ}$ anos) do Ensino Fundamental do município de Barueri. 
No projeto inicial, a pesquisa se restringia aos docentes do último ano do Ensino Fundamental e sua relação com o jornalismo; no entanto, à medida que a investigação era realizada, observei a necessidade de incluir os professores de mais um ano ( $8^{\circ}$ ano). Ainda, por tratar-se de um público receptor adolescente, resolvi acrescentar também a publicidade, pelo uso de imagens, ícones e marcas tão presentes no cotidiano destes jovens. Apresentei a ideia ao orientador que concordou com a proposta e direcionou o meu enfoque às linguagens da comunicação.

\subsection{Justificativa da escolha do tema ${ }^{4}$}

Sou jornalista e pedagoga por formação e sempre tive interesse pelas duas áreas ${ }^{5}$. Por várias vezes, questionei se não existiria uma forma de interligá-las: do lado da Comunicação, notava como o pensar educativo era necessário; do outro lado, também, afinal, para a Educação, a Comunicação renova e incorpora diálogos imprescindíveis para a melhoria da qualidade do ensino.

As graduações me trouxeram teorias e linhas de pensamento, mas as práticas exigiram um repensar com o cuidado de não privilegiar uma área determinada. Atualmente, apesar de estar mais envolvida no contexto educacional, o ingresso na pós-graduação, na referida linha de pesquisa, me fez compreender a Educação a partir da Comunicação: um grande desafio. Confesso que essa perspectiva provocou uma análise sobre as diferenças entre os campos, suas divergências, aproximações e singularidades. E foram essas observações que ampliaram o respeito e a vigilância necessária, sob o meu ponto de vista, entre as áreas, e me colocaram no papel de investigadora, de alguém que, apesar de estar envolvida com o lado educacional e ter parâmetros reais do lado da comunicação, busca uma nova compreensão: a da interface.

Ressalto que a posição aproximada com o universo educacional e o acesso aos professores da rede municipal de Barueri não possibilitaram, como possa parecer, um trabalho de campo com facilidades, já que o projeto não estava finalizado, foi sendo construído ao longo do tempo. Assim, exigiu o repensar das etapas da pesquisa, pois, pela função exercida no sistema, precisei de redobrada atenção sobre os caminhos a serem percorridos e as técnicas a serem utilizadas. Apesar das afinidades com as áreas, a importância teórica e a social

\footnotetext{
${ }^{4}$ Em aula de Metodologia de Pesquisa em Comunicação, com a professora Maria Immacolata Vassallo de Lopes, em junho de 2011 na Escola de Comunicações e Artes (ECA/USP).

${ }^{5} \mathrm{O}$ relato da justificativa de escolha do tema, nesta primeira parte, será na $1^{a}$ pessoa do singular para dar o destaque necessário aos motivos que direcionaram a construção da pesquisa. Na segunda parte, prevalece a $1^{\mathrm{a}}$ pessoa do plural até o final.
} 
pesaram, consideravelmente, em minha investigação, sendo esta última de grande relevância por tratar-se não apenas do universo de uma unidade escolar, mas de todo o município.

Além das afinidades descritas, outro fator que me motivou no processo construtivo deste trabalho foi abordar a prática docente, como revelado na pesquisa, de profissionais com faixa etária de 39 a 49 anos, média de 15 anos de exercício no magistério, inseridos num modelo escolar formal, que, de acordo com Maria da Glória Gohn, é aquele formado pela instituição normatizada e oficial.

A autora aponta, além da educação formal, a existência de outras duas instâncias educacionais: a não-formal, constituída pelos processos educativos das organizações e movimentos sociais, e a informal, decorrente do convívio com a família, amigos e meios de comunicação. Sendo assim, os conteúdos veiculados pela mídia situam-se neste terreno, no qual não há intenção de formação específica. "O que diferencia a educação não-formal da informal é que na primeira existe a intencionalidade de dados, dos sujeitos em criar ou buscar determinadas qualidades e/ou objetivos" (GOHN, 2008:100).

Nossa pesquisa versa, portanto, sobre professores que lecionam em instituições de ensino formais junto a adolescentes entre 13 e 15 anos de idade que cursavam os últimos anos do Ensino Fundamental. Ressaltamos que os adolescentes já nasceram em época de expansão da internet, que, para Manuel Castells, "não é simplesmente uma tecnologia; é o meio de comunicação que constitui a forma organizativa de nossas sociedades" e continua "a Internet é o coração de um novo paradigma sociotécnico que constitui na realidade a base material de nossas vidas e de nossas formas de relação, de trabalho e de comunicação" (2003:287).

Hoje, na perspectiva deste autor, o que se observa é o ingresso na escola de um "novo aluno", que olha, ouve, sente, sonha, percebe, fala de forma articulada, fragmentada e totalmente dependente das tecnologias: celulares, PPads $^{6}$, computadores e redes sociais (Twitter ${ }^{7}$, Facebook $^{8}$, Orkut $^{9}$, YouTube $^{10}$, Messenger $\left.^{11}\right)$.

\footnotetext{
${ }^{6}$ iPad: dispositivo em formato tablete (tablet) da empresa Apple.

${ }^{7}$ Twitter: rede social que permite aos usuários enviar e receber atualizações pessoais em textos de até 140 caracteres.

${ }^{8}$ Facebook: rede social lançada em 2004. Nela, os usuários criam perfis que contêm fotos e listas de interesses pessoais, trocam mensagens privadas e públicas entre si e participam de grupo de amigos.

${ }^{9}$ Orkut: rede social filiada ao Google, com o objetivo de ajudar seus membros a conhecer pessoas e manter relacionamentos.

${ }_{11}^{10}$ YouTube: site que permite que seus usuários carreguem e compartilhem vídeos em formato digital.

11 MSN Messenger é um programa de mensagens instantâneas criado pela Microsoft Corporation. O serviço permite falar com uma pessoa através de conversas instantâneas pela Internet em tempo real.
} 
A pesquisa "A Geração Interativa na Ibero-América: crianças e adolescentes diante das telas"12 apresenta uma constatação disso; realizada pela Fundação Telefônica em parceria com a Universidade de Navarra (Espanha), revela dados importantes sobre a procura dos adolescentes por novas linguagens e formas de leitura e escrita.

A amostragem no Brasil, concentrada no Estado de São Paulo, abrangeu 4.205 alunos de escolas públicas e privadas: 790 com idade entre 6 e 9 anos e 3.145 entre 10 e 18 anos. A investigação apontou que, em nosso país, os jovens buscam caminhos próprios de comunicação, com destaque para o uso da internet com criação de blogs e participação em redes sociais.

Os resultados também indicaram que o ensino precisa cada vez mais se encontrar, adquirir sentido no contexto juvenil, pois o que se observa na escola, sobretudo da esfera pública, é a predominância da cultura escrita em detrimento dos recursos audiovisuais e digitais. Neste aspecto, as linguagens da comunicação, tanto da esfera jornalística como da publicitária, só que do suporte impresso, são constantemente utilizadas como formas de avaliação pelos sistemas educacionais, no que tange à produção textual em Língua Portuguesa, em todas as esferas governamentais: municipal, estadual e federal.

O questionamento sobre as habilidades mínimas para que um educando adquira a competência $^{13}$ leitora e escritora e consiga concluir o Ensino Fundamental (nove anos) apto a prosseguir no Ensino Médio permeia discussões entre educadores, governos e meios de comunicação. Os conteúdos curriculares das disciplinas de Língua Portuguesa e Matemática são permanentemente exigidos nas diversas avaliações oficiais externas, às quais os adolescentes do $8^{\circ}$ e $9^{\circ}$ anos (antigas $7^{\mathrm{a}}$ e $8^{\mathrm{a}}$ séries) do Ensino Fundamental são submetidos.

Como exemplo, no Estado de São Paulo, temos o Saresp ${ }^{14}$ (Sistema de Avaliação do Rendimento Escolar do Estado de São Paulo), passando pela Prova Brasil ${ }^{15}$ e Saeb (Sistema Nacional de Avaliação da Educação Básica), realizados pelo Instituto Nacional de Estudos e Pesquisas Educacionais Anísio Teixeira (Inep) e Ministério da Educação (MEC). Além

\footnotetext{
${ }^{12}$ A pesquisa, de março de 2009, foi realizada no Brasil, Argentina, Chile, Colômbia, México, Peru e Venezuela.

13 A competência, de acordo com Philippe Perrenoud (2002), é formada por três características: tomada de decisão, mobilização de recursos e saber agir, quanto à construção, coordenação e articulação de pensamento.

${ }^{14}$ Matrizes de Referência para Avaliação: Saresp. Documento básico/Secretaria da Educação. Coordenação Geral: Maria Inês Fini. São Paulo: SEE, 2009.

${ }^{15}$ A Prova Brasil e o Sistema Nacional de Avaliação da Educação Básica (Saeb) são avaliações para diagnóstico, em larga escala, desenvolvidas pelo Instituto Nacional de Estudos e Pesquisas Educacionais Anísio Teixeira (Inep/MEC). Avaliam o sistema de ensino educacional brasileiro. Os testes são aplicados em alunos do quinto e nono anos do Ensino Fundamental em Língua Portuguesa e Matemática. Professores, gestores e escolas são avaliados e as médias de desempenho no Saeb e Prova Brasil servem de subsídios para o cálculo do Índice de Desenvolvimento da Educação Básica (Ideb).
} 
destas, em Barueri, semestralmente é aplicada a avaliação externa no Ensino Fundamental, colaborando com o extenso percurso de verificações de aprendizagens.

Nas matrizes de referência para a avaliação do Saresp, em Língua Portuguesa, em situações de leitura de gêneros escritos não literários ${ }^{16}$ para os estudantes do $9^{\circ}$ ano, estão competências como: "interpretar textos relacionando com seu contexto; considerando fatores como gênero, assunto, suporte original; identificar os elementos constitutivos da organização interna dos gêneros escritos não literários; estabelecer relações entre imagens (fotos, ilustrações), gráficos, tabelas, infográficos e o corpo do texto", que demonstram o quanto cabe o uso das linguagens comunicacionais do jornalismo e da publicidade em sala de aula.

Na produção textual do referido ano, o Saresp solicitou aos estudantes a elaboração de um gênero jornalístico, no caso, um artigo de opinião, com base em uma proposta que estabeleceu: tema, linguagem, finalidade e interlocutores. O estabelecimento de relações entre texto, imagens (fotos, ilustrações), produção, interpretação, e sua relação com os contextos, são algumas das inúmeras habilidades ${ }^{17}$ requeridas em testes que podem ser obtidas com o uso dessas linguagens.

Nesses tipos de provas governamentais, os gêneros das esferas comunicacionais predominantes ainda são do suporte do impresso. Em certo sentido, isso reflete o distanciamento entre as gerações. De um lado, um professor que não nasceu com a internet e está "obrigatoriamente" passando pelo processo de "inclusão"; de outro, um adolescente que fica desmotivado porque compreende e convive com os recursos audiovisuais e digitais e se sente incomodado e "excluído" da aula deste professor, centralizado na prática com a linguagem verbal e nas exigências das provas oficiais.

Mauro Wilton de Sousa (2006) resgata os diversos sentidos que as práticas escolares vêm assumindo no contexto sócio-histórico com o passar do tempo. O autor propõe que atualmente há pelo menos três direções que marcam essas modificações, destacando o papel das mediações socioculturais da contemporaneidade. Aponta: a mudança do modelo de sociedade derivado da modernidade capitalista que caracterizava a sociedade até meados do século XX; as novas relações que a sociedade estabelece com a tecnologia, de onde resulta a hegemonia do entretenimento sobre o saber e da imagem e do som sobre a escrita,

${ }^{16}$ Matrizes de Referência para Avaliação: Saresp. Documento básico/Secretaria da Educação. Coordenação Geral: Maria Inês Fini. São Paulo: SEE, 2009. p. 30. Na classificação de gêneros não literários no Saresp estão: propagandas institucionais, regulamentos, notícias, cartazes informativos, artigos de opinião, entrevistas, resenhas, resumos, tabelas, legendas, gráficos etc.

${ }^{17}$ PERRENOUD, P. Construir as competências desde a escola. Porto Alegre: Artmed, 1999. Por habilidade, Perrenoud entende uma “'inteligência capitalizada', uma sequência de modos operatórios, de analogias, de intuições, de induções, de deduções, de transposições dominadas, de funcionamentos heurísticos rotinizados que se tornaram esquemas mentais de alto nível ou tramas que ganham tempo, que ‘inserem' a decisão”. p. 30. 
configurando novos modos de ver a vida e o mundo, de se posicionar quanto às instituições formadoras, representadas social e culturalmente por família, igreja, escola, partidos etc.; a transformação da relação entre a escola e a comunicação ao longo da história recente, implicando atitudes pedagógicas muitas vezes complexas e conflituosas.

$\mathrm{Na}$ visão de Sousa, são essas mediações que atuam na ressignificação do lugar da escola, professores, alunos e "das práticas e estratégias didático-pedagógicas, em um processo de lenta negociação e que já se torna perceptível em seus traços nos diversos conflitos que vemos emergir no ambiente escolar" (2006:122).

A escola é vista pelo autor (SOUSA, 2006:131) como um local de manifestação desses conflitos:

\begin{abstract}
Nesse contexto, a escola passou a ser o agente da hegemonia da escrita, do saber, da razão e também, por outro lado, começou, paulatinamente, a ser um espaço de rejeição às outras formas de aquisição do conhecimento. A imagem e outras maneiras mais lúdicas e intuitivas de apreensão do saber foram as que mais sofreram por essa descaracterização (...). Nesse sentido podemos dizer que a escola foi um dos agentes mais importantes da hegemonia da escrita e da exclusão do que chamamos atualmente de audiovisual (escrita+imagem+som) como espaço de aprendizado.
\end{abstract}

Concordamos com Sousa quanto à incorporação de fazeres pedagógicos que dialoguem mais com o contexto da época, ou melhor, de ações que amenizem os conflitos entre epistemes ${ }^{18}$ e de estratégias para fazer do universo escolar um lugar de comunicação, troca de sentidos, construção de identidades, considerando as diferenças e as intervenções que se apresentam como hegemônicas no período.

Sendo assim, ainda que os educadores possam se sentir muitas vezes "invadidos" e "ameaçados" pelos meios de comunicação atuais e pelas tecnologias no que tange ao ensino e aprendizagem, eles possuem um papel importante no processo de mediação do conhecimento, o que não é novidade.

A relação professor, meios de comunicação e discursos suscita investigações desde a década de 90. Em pesquisas realizadas nos anos 1992 e 1993, especificamente no Projeto

${ }^{18} \mathrm{O}$ conceito de episteme utilizado por Sousa é de Michel Foucault. Para Foucault, em cada época há um conjunto de ideias e comportamentos dominantes, ou hegemônicos, que determina aquilo que é aceito socialmente como a conduta padrão ou normal. 
Integrado de Pesquisas “A circulação de textos na escola”, Adilson Citelli (1997:21) tratou de uma das crises vividas pela escola:

O descompasso existente entre o estrito discurso didático-pedagógico e as linguagens não institucionais escolares. Um formalizando as ações na sala de aula, constituindo a natureza "única e diferenciada" do discurso escolar; outra pressionando "de fora", existindo na fala dos alunos, tomando boa parte do seu tempo circulando de forma subterrânea.

Tal como postula o pesquisador, o "discurso subterrâneo" existente na instituição escolar, local onde as linguagens da mídia e as novas tecnologias circulam livremente, confronta-se com as respostas dos professores pesquisados na época quanto à ausência quase completa das "linguagens institucionais não escolares".

Em continuidade à temática, ou seja, como os docentes se inserem no interior das relações comunicativas, entre 2006 e 2008 Citelli realizou novas e amplas pesquisas, agora abarcando os docentes na faixa etária de 30 anos. O objetivo era analisar como os educadores (pelo fato de terem acompanhado o advento da internet) haveriam de modificar suas metodologias em relação à cultura midiática.

Os resultados revelaram que "as práticas em sala de aula não parecem ter mudado substancialmente pelo fato de os jovens docentes estarem mais integrados aos circuitos da comunicação" (CITELLI, 2010a:23). Em outras palavras, mostraram que, apesar da idade e contato com novos meios e recursos, eles não trouxeram para o cotidiano da sala de aula modificações significativas, apesar da amplitude de acesso a elas.

Outra publicação sobre o universo educacional no Brasil, "Ser professor: uma pesquisa sobre o que pensa o docente das principais capitais brasileiras", elaborada pelo Instituto Brasileiro de Opinião Pública (IBOPE) ${ }^{19}$, divulgou dados relevantes sobre as ações didáticopedagógicas, incluindo desde o planejamento dos conteúdos até os recursos utilizados em sala de aula. De acordo com o levantamento, entre os materiais preferidos pelos professores o livro didático é o primeiro da lista para 79\%, seguido de revistas para 57\%, jornais para 53\% e internet para 49\%. Nesta perspectiva, em relação aos suportes estão os livros (68\%), DVDs $(54 \%)$ e televisores $(52 \%)$.

\footnotetext{
${ }^{19}$ A pesquisa foi realizada em 2007 pelo IBOPE e pelo Instituto Paulo Montenegro sob encomenda da Fundação Victor Civita. O material foi publicado no livro: Estudos e Pesquisas Educacionais, ${ }^{\circ}{ }^{0}$. São Paulo: mai/2010.
} 
O estudo destacou a função desses materiais em sala: debates, trabalhos em grupo, análise e interpretação de textos. Os números indicam que, apesar do advento da tecnologia, o texto impresso ainda é hegemônico na preparação das aulas. Sobre as temáticas mais abordadas, os pesquisados responderam: "reportagens sobre violência, política, esporte e outras atualidades, bem como matérias sobre saúde e meio ambiente, além de propagandas".

Nas informações obtidas, os gêneros jornalísticos notícia e reportagem e os publicitários anúncio e slogan são citados como os mais usados na escola. Independentemente do meio de comunicação, verificamos que suas linguagens estão atreladas à ação pedagógica dos professores, pois os resultados apontaram que as informações da mídia são incorporadas como material de apoio por $92 \%$ deles. Entre os principais aparatos midiáticos, encontram-se, na seguinte ordem: jornais, revistas, televisão, internet, rádio e filme.

Os diversos estudos apresentados validam nosso pressuposto, pois revelam que o professor está diretamente em contato e se apropriando de informações pautadas pela mídia, ainda que as transposições didáticas perpassem o objetivo da informação veiculada e as peculiaridades em sala e área de conhecimento possibilitem outras formas de leitura e trabalho. Sendo assim, é fato que as linguagens das esferas jornalística e publicitária circulam e estão, em certa medida, presentes no cotidiano do ambiente escolar.

Embora a circulação desses textos neste espaço não garanta um aprendizado de qualidade, ao menos possibilita o despertar e o contato dos sujeitos envolvidos com novas visões de mundo.

O educador Paulo Freire (1992), ao abordar o papel do docente exigente, crítico e coerente, descreve um profissional que, no exercício de sua reflexão compreende o agir educativo em sua totalidade. Acreditamos, como Freire, que não é possível, na atitude democrática, que os docentes "imponham aos alunos sua leitura de mundo, em cujo marco situa o ensino do conteúdo" (1992:112). Contudo, compreendemos, como ele, que não existem neutralidades no trabalho em sala de aula. Nesse aspecto, a chamada relação dialógica é de grande valia, ou seja, as discussões de ideias não devem ser reduzidas a um mero "batepapo", desobrigado, que marche ao acaso; Freire destaca a importância do "diálogo pedagógico", que gira não apenas em torno do objeto, conteúdo, exposição, mas do todo dessa relação. Nas palavras do autor (1992:119):

O mal, na verdade, não está na aula expositiva, na explicação que o professor ou professora faz. Não é isso que caracteriza o que critiquei como prática bancária. Critiquei e continuo criticando aquele tipo de relação 
educador-educando em que o educador se considera o exclusivo educador do educando.

Nesta linha de pensamento, enxergamos o professor como mediador do conhecimento, com condições de possibilitar aos alunos novas e diversificadas "leituras de mundo", na acepção freiriana do termo, por meio do trabalho com as linguagens da mídia, percebendo os meios como mais uma fonte mediadora de saberes. Daí a importância deste profissional reconhecer que existem outras formas de interpretação, diferentes da sua e até mesmo antagônicas a ela, caso, muitas vezes, que pelo não reconhecimento propaga tensões.

Em relação a Freire, retomamos o seu conceito de "leitura de mundo", tão propalada em A importância do ato de ler. Para o educador brasileiro, a leitura de mundo "precede a leitura da palavra, linguagem e realidade se prendem dinamicamente. A compreensão do texto a ser alcançado por sua leitura crítica implica a percepção da relação entre texto e contexto" (FREIRE, 2000:12).

Outro pedagogo progressista, o francês Georges Snyders, em sua obra Alunos Felizes, com prefácio de Paulo Freire na edição brasileira, defende a utilização dos textos comunicacionais no ambiente escolar e um ensino prazeroso e alegre. O educador (1991) postula a incorporação pela instituição escolar do universo cultural veiculado pelos meios de comunicação e legitima a possibilidade de que a escola formal inclua em seu currículo estes textos ditos "não-literários".

Para Snyders, com a integração destes aos conteúdos curriculares, é possível dar-lhes um tratamento crítico adequado, o que significa proporcionar abertura aos jovens, aprofundar o que for superficial e extinguir o que houver de generalização e preconceito.

O autor explana sobre a possibilidade de encontro da educação (escolar, sistematizada) com a cultura comunicacional para que ambas, apesar de dicotômicas, possam ser tratadas de maneira que se equilibrem no que possuem em comum. Afirma, assim, ser necessário que os professores considerem o contexto social no qual o aluno está inserido, gostos, preferências, comportamentos e até mesmo referências quanto à leitura, linguagens e aparatos tecnológicos, para que essa confluência das "culturas" da mídia e escolar possa fazer sentido para as novas gerações. Por isso a crítica ao excesso de apego ao passado no ensino:

Arcaísmo: os professores (e também os pais) tendem a apresentar aos jovens as ideias e os livros que lhe agradavam antigamente, quando tinham a mesma idade que eles. $\mathrm{O}$ círculo fechado da escola parece muito propício a 
tal passadismo, diante do que toda a geração reclama o direito à originalidade, vive a novidade do seu mundo e reivindica ser diferente - e é disso que ela espera sua alegria (SNYDERS, 1991:121).

O francês aponta para a distância entre a escola - leia-se também professores, e o cotidiano dos alunos, que, na visão dele, corresponde ao mundo autêntico; "daí o emprego pejorativo do termo escolar para denunciar o que não tem relação com a vivência real" (1991:120). O pedagogo critica o modelo escolar "tradicional" pelas dificuldades em se adaptar aos requisitos da sociedade contemporânea, marcada por novos modos de leitura e sensibilidades, enfim, por essa estrutura educacional não colaborar com as reais necessidades do aluno atual.

\subsection{Formulação do problema}

O objeto de nossa pesquisa são as linguagens do jornalismo e da publicidade inseridas nas escolas da rede municipal de Barueri. Os sujeitos são os docentes de Língua Portuguesa dos anos finais $\left(8^{\circ}\right.$ e $9^{\circ}$ anos $)$ do Ensino Fundamental.

Fizemos a opção pelas referidas linguagens e educadores com vistas a compreender como os circuitos midiáticos são usados no cotidiano pedagógico destes profissionais e, consequentemente, como são recepcionados pelos alunos.

De acordo com Lopes, o problema de pesquisa situa-se num conjunto mais amplo, que é o assunto ou tema: o primeiro é constituído e o segundo é escolhido pelo investigador (2005:138). O engajamento teórico, o comprometimento social e as condições institucionais são fatores intervenientes na escolha e direcionam os caminhos teóricos e práticos.

Uma vez que o assunto traz em si uma problemática sempre vinculada a um modelo teórico, é mediante um procedimento quase sempre dedutivo que se chega a especificar o problema da pesquisa. Costuma-se partir de um problema abrangente até se conseguir a "pergunta-chave" que a pesquisa deve responder. (LOPES, 2005:138) 
Nesta perspectiva, pretendemos verificar diversos conteúdos: como as linguagens comunicacionais das esferas jornalística e publicitária estão inseridas na prática pedagógica do professor de Língua Portuguesa dos últimos anos do ciclo final do Ensino Fundamental; se o docente tem consciência das relações entre comunicação e educação e seus significados; quais linguagens do universo delimitado são mais utilizadas pelos educadores, bem como os motivos pela opção de uma em detrimento de outra; a percepção do professor quanto às necessidades dos adolescentes contemporâneos; se as linguagens elencadas pelos docentes são mais utilizadas em decorrência da organização dos planejamentos oficiais da rede municipal; em que medida os alunos correspondem às expectativas dos conteúdos propostos com o uso do jornalismo e da publicidade.

Assim, com base no modelo metodológico adotado e mediante o exposto, o problema que permeará nossa pesquisa é: Como as linguagens da comunicação das esferas jornalística e publicitária são legitimadas na prática pedagógica dos docentes de Língua Portuguesa dos anos finais do Ensino Fundamental em Barueri?

\subsection{Objetivos da pesquisa}

Os objetivos da pesquisa também decorrem da formulação do problema. "Fixados nessa primeira fase, eles devem ser exequíveis e podem conjugar várias ordens: empírica (verificar determinado fenômeno da realidade), teórica (contribuir para o estudo da teoria sobre o problema) e prática (intervir na existência do fenômeno).” (LOPES, 2005:139)

Ao elencarmos em nosso estudo os pontos que o direcionam, primeiramente consideramos dois aspectos fundamentais: o tempo e os recursos disponíveis para sua realização. Por tratar-se de uma pesquisa de Mestrado com tempo bastante reduzido, definimos nossas metas com vistas ao prazo estabelecido, de forma a elaborar um planejamento coerente sem extrapolarmos os limites propostos. Quanto à disponibilidade de materiais para as coletas e idas a campo, coube a organização do pesquisador e apoio da instituição investigada.

Com vistas a melhorar a visualização e encaminhamento da pesquisa, os objetivos estão divididos em gerais e específicos, conforme apresentamos a seguir: 


\section{Gerais}

- Identificar os hábitos midiáticos do professor;

- Identificar a percepção que o professor tem da recepção do aluno no trabalho com as linguagens;

- Verificar se o sistema de ensino influencia e até interfere, mesmo que indiretamente, no processo de utilização das linguagens da comunicação no universo da sala de aula.

\section{Específicos}

- Investigar a apropriação que o docente de Língua Portuguesa faz das linguagens da comunicação em sua ação pedagógica;

- Verificar as linguagens comunicacionais preferidas pelos docentes e os motivos que legitimam essas escolhas;

- Identificar as principais dificuldades que o docente encontra no trabalho com essas linguagens;

- Verificar como o docente se relaciona com as linguagens das esferas jornalística e publicitária diante do ensino de Língua Portuguesa;

- Identificar a relação do professor com os alunos nas atividades propostas em sala de aula quanto a estes tipos de linguagens.

Para o cumprimento dos objetivos relacionados, faz-se necessária a compreensão teórica dos fenômenos verificados, que será possibilitada por um aprofundamento do Quadro Teórico de Referência proposto a seguir, com base nas orientações de leituras e referências da banca de qualificação e, sobretudo, nas considerações e discussões com o orientador. 


\section{QUADRO TEÓRICO DE REFERÊNCIA}

\subsection{As teorias sustentadoras: da Cultura à interface comunicação/educação}

Discutiremos, neste capítulo, a interface comunicação-educação no contexto escolar do Ensino Fundamental de Barueri e as relações entre professores e alunos. Baseamo-nos no pressuposto de que, na sociedade contemporânea, os novos modos de produzir e circular o conhecimento requisitam, cada vez mais, a aquisição de novas habilidades e competências, o que exige do ambiente formal de ensino e aprendizagem, ou seja, da escola, o repensar de práticas pedagógicas e estratégias que perpassam o conteúdo curricular estabelecido. As colocações apresentadas suscitam tensões não apenas na relação docente/discente, mas em toda forma de organização de ensino.

Em nossa reflexão, buscaremos trilhar um caminho que parte da Comunicação, transita pela Educação e eclode na integração entre os campos, sem desconsiderar que todo o processo de transmissão da mensagem depende muito de elementos mediativos e da construção de sentidos que ocorre justamente nas trocas de ideias.

A admissão da existência do diálogo entre as duas áreas significa, como ressalta Adilson Citelli, “constatar que não se aprende/apreende mais como ocorria em tempos dominados por ciclos do conhecimento constituídos, apenas, em torno da oralidade primária ou da escrita" (2006:163). Neste aspecto, é assumir a existência de novas atitudes e objetivos, com a inserção do audiovisual e da esfera digital que obrigam a incorporação de outras linguagens, além da verbal na escola.

Nossa proposta de discussão - o Quadro Teórico de Referência (QTR) - começa com reflexões acerca da perspectiva dos Estudos Culturais, por nós entendida como apropriada para a compreensão da pesquisa, pois abrange resgates conceituais que dialogam com o objeto empírico, tais como: os gêneros, a construção de sentidos, as mediações, a interface e as ações educomunicativas. Na perspectiva educacional, abordamos a visão do conceito de autonomia, por diversos autores, no entendimento da relação educador/educando e a rede educativa em questão.

A interligação comunicativa no espaço escolar produz práticas, com vistas à integração e ao fortalecimento de vínculos, valorizando atitudes democráticas, que colaboram para um estudo mais amplo e contínuo quanto aos meios comunicacionais. 
Acreditamos que as sociedades modernas são, portanto, por definição, sociedades em mutação permanente, como argumenta Anthony Giddens (1991:37-38), modelos de organização nos quais "as práticas sociais são constantemente examinadas e reformadas à luz das informações recebidas sobre aquelas próprias práticas, alterando, assim, constitutivamente, seu caráter”.

Seguindo esta tendência, as linguagens do jornalismo e da publicidade conquistam espaços cada vez maiores e interferem na dinâmica social. Além disso, refletem na sala de aula e atuam diretamente na ação docente, recepção discente e uso dos aparatos tecnológicos. Ao discutirmos nossa temática de pesquisa, apoiaremo-nos no pressuposto que postula que Comunicação, Educação e Cultura se convergem.

\subsection{Estudos Culturais: diálogos com a Comunicação}

As perspectivas dos chamados Estudos Culturais são abordadas em nosso trabalho a partir da Comunicação. Ressaltamos que seria um erro reduzir essa linha de pensamento a um "modelo" para a área, considerando que essa tradição ultrapassa o campo comunicacional e transita por outros. Por isto, elaboramos um breve recorte histórico com conceitos e autores que corroboram na construção de um quadro, o qual, posteriormente, fará diálogos com tópicos de nossa investigação.

Em 1964, Richard Hoggart funda o Centre for Contemporary Cultural Studies (CCCS) e origina de forma organizada os Estudos Culturais britânicos, inspirado em sua pesquisa The Uses of Literacy de 1957. O centro surge em parceria com o English Departament da Universidade de Birmingham e se firma como seu centro de pós-graduação. Neste local, aspectos da cultura contemporânea e o relacionamento com as práticas e instituições serão os focos de análise.

Na leitura de Ana Carolina Escosteguy (2001:158), “os estudos culturais britânicos devem ser vistos tanto do ponto de vista político, na tentativa de constituição de um projeto político, como do ponto de vista teórico, na tentativa de construir um novo campo de estudo".

Para Escosteguy (2001:152), três textos do final da década de 50 são identificados como as fontes desta corrente: o já citado The Uses of Literacy de Richard Hoggart (1957), em parte autobiográfico e em parte história cultural da metade do século XX; Culture and Society (1958), de Raymond Williams, no qual o autor apresenta um histórico do conceito de 
cultura "em comum e ordinária", que pode ser entendida com um modo de vida em condições de igualdade - o que se observa é uma crítica de Williams à dicotomia entre cultura e sociedade, e The making of the english working class (1963), de Edward Palmer Thompson, uma obra que reconstrói uma parte da trajetória da sociedade inglesa de um ponto de vista da "história dos de baixo".

Williams é um autor fundamental na construção dos percursos deste grupo. O teórico acredita que a questão cultural é a categoria-chave entre análise literária e investigação social. Em outra obra, The Long Revolution (1961), discorre sobre a relação contemporânea e o impacto dos meios de comunicação, aproveitando para demonstrar seu pessimismo, tanto com relação aos meios, quanto no que se refere à própria cultura popular.

Atualmente, o conceito de cultura é tratado na convergência de aspectos das duas principais correntes: a materialista e a idealista. Segundo Williams (1992:12), o tratamento materialista mantém seu enfoque em "uma ordem social global no seio da qual uma cultura específica, quanto aos estilos de arte, tipos de trabalho intelectual, é considerada produto direto ou indireto de uma ordem primordialmente constituída por outras atividades sociais" (cultura como produto). No pertinente à análise idealista, Maria Luiza Mendonça (2006) ressalta que a ênfase é dada à cultura enquanto "espírito formador", àqueles grandes relatos nacionais que englobam tendências artísticas e intelectuais, os quais permeiam todo o conjunto das atividades especificamente - a linguagem, as artes e o pensamento (cultura como produtora).

A convergência a que Raymond Williams se refere permite um entendimento da existência de relações dialógicas entre itens culturais e organização mundial; sendo assim, as experiências da sociedade possuem papel determinante quanto à diversidade de práticas em seu contexto, as quais também são influenciadas pelos padrões da época. Sob esse viés, requisitam a inclusão de orientações em um sistema simbólico e de esquemas de significados que atribuem sentido às relações e ações dos indivíduos.

O teórico critica o determinismo tecnológico ao tratar sobre as mídias e em cada uma de suas análises estuda o caráter histórico que os meios comunicacionais: televisão, imprensa e publicidade, acabam assumindo perante uma dada realidade.

Os quatro textos citados de Hoggart, Thompson e Williams tornaram-se importantes para a configuração dos Estudos Culturais. Entretanto: 
impulso intrínseco. Quer fossem históricos ou contemporâneos em seu foco, tais textos eram eles próprios, focalizados pelas impressões imediatas do tempo e da sociedade na qual foram escritos, organizados através delas, além de serem elementos constituintes de respostas a essas pressões. (HALL, 1996:32)

Embora não seja citado entre os membros fundadores dos Estudos Culturais britânicos, o jamaicano Stuart Hall, cuja contribuição será exposta posteriormente, tem sua participação unanimamente reconhecida.

A partir da década de 70, a importância dos meios de comunicação de massa, vistos não apenas como opção de lazer, mas também como aparelhos ideológicos do Estado, começa a ser verificada. $\mathrm{O}$ foco passa a ser a análise da estrutura ideológica da cobertura jornalística. Hall nominou essa fase de "redescoberta da ideologia", sendo um dos pressupostos a ideia de que os efeitos dos meios poderiam ser deduzidos das análises das mensagens que veiculam.

Os pesquisadores de Birminghan (CCCS), a partir da divulgação do texto Ecoding and decoding in the television discourse, de Stuart Hall, publicado pela primeira vez em 1973, passam a observar a temática da recepção e do consumo. Após um período de análises textuais, os estudos sobre os processos receptivos tiveram início. Nesta obra, Hall examina o processo de comunicação da televisão em quatro momentos: produção; circulação; distribuição/consumo; reprodução, que, apesar de apresentarem suas formas e caminhos existenciais, articulam-se entre si devido às relações de poder institucional.

A partir dos anos 80, os Estudos Culturais são descentralizados da Grã-Bretanha e se direcionam com ênfase para a investigação das audiências, área de pesquisa que se torna própria desta corrente. Nesse momento, ocorre a incorporação do modelo de codificação e decodificação também proposto pelo jamaicano.

A partir do final da década de 90, a reflexão sobre a função dos veículos comunicacionais na constituição identitária é o campo de atuação desta perspectiva de estudo que se espalhou sobre diversas partes do mundo, inclusive para a América Latina. É fato que o entendimento do conceito de identidade no sentido mais tradicional tem relação direta com o momento histórico e valores de uma dada sociedade. Considerando que, a partir da segunda metade do século XX, esses padrões ou lugares sociais modificaram-se rapidamente.

Hall denomina este novo cenário como sendo o da centralidade da cultura: "a expansão de tudo o que está associado a ela e ao seu papel constitutivo, hoje, em todos os aspectos da vida social" (1997:17-18). Neste sentido, a cultura penetra em cada recanto da 
vida, mediando tudo: está presente nas vozes, imagens e símbolos que nos interpelam nas telas, revistas, jornais, outdoor etc. Segundo o autor, a importância das revoluções culturais está situada na abrangência de seu impacto e em seu teor democrático e popular.

Para ele (1997), é na contemporaneidade que ocorre o rompimento com as noções de uma fixação identitária. Isto significa que na atualidade a centralização está justamente na flexibilidade deste aspecto, ou seja, em seus fragmentados e deslocados papéis em relação ao tempo e tradições.

Acrescenta ainda que essas transformações mudaram "nossas identidades pessoais, abalando a ideia que temos de nós próprios como sujeitos integrados. Essa perda de um sentido de si estável é chamada de descentração do sujeito" (HALL, 1997:9). Esta é a descrição dada pelo autor ao chamado indivíduo pós-moderno, um indivíduo que é definido historicamente e não biologicamente e, por isto, assume funções diferentes de acordo com o momento em que vive.

\subsection{As configurações do contexto (pós) moderno}

A compreensão da estrutura societária e das configurações do período histórico atual é essencial para o entendimento de nossa pesquisa, afinal, os profissionais envolvidos e as relações estabelecidas com o nosso objeto encontram-se inseridos neste contexto.

As modificações sociais, a partir da segunda metade do século XX, proporcionaram análises de especialistas dos mais diversos campos: de historiadores, psicólogos, sociólogos, filósofos e antropólogos, os quais discutem as consequências dessas transformações que vigoram até hoje.

Muitos destes estudos resultaram em concepções que possibilitam mensurar, em certa medida, este momento. Entre os vocábulos, um em especial abre espaço para linhas de pensamento divergentes: por isto, acrescentamos os parênteses à ideia de (pós) modernidade, com vistas a dialogar, de um lado, com autores que não acreditam no fim da Modernidade e, de outro, com os que afirmam que ela acabou e já vivemos em outra época.

Este último é o caso do filósofo italiano Gianni Vattimo, para quem o sentido do termo pós-moderno está ligado ao fato de vivermos em uma sociedade de comunicação generalizada, a sociedade do mass media, e é por este viés que ele faz sua leitura. Para Vattimo, abordar este conceito significa admitir que, em seus aspectos essenciais, a 
modernidade acabou. "Na hipótese que proponho, termina quando - por múltiplas razões - já não parece possível falar de história como qualquer coisa de unitário" (1992:8).

O filósofo postula que a Sociedade Transparente, termo que intitula sua obra, é uma sociedade na qual os meios de comunicação têm papéis determinantes e são os responsáveis por caracterizá-la como tal; sob seu ponto de vista, é uma estrutura mais consciente de si. Apesar desta suposta transparência, esta organização é mais complexa e caótica que as anteriores e é justamente nesta 'confusão' que residem as esperanças de emancipação.

Este modelo social está fundamentado na diversidade, as fragmentações são reflexos do desgaste do princípio de realidade que, por sinal é "o resultado do cruzamento, da ‘contaminação' (no sentido latino) das múltiplas imagens, interpretações, reconstruções que, em concorrência entre si, seja como for, sem qualquer coordenação central, os media distribuem"(VATTIMO, 1992:13).

$\mathrm{Na}$ leitura do italiano existe uma desorganização do real no modelo societário que vivemos devido a proliferação imagética e mercadológica que os meios comunicacionais perpetuam constantemente em suas mensagens, as quais parecem prender os indivíduos. A pergunta seria como ocorreria uma possível capacidade de libertação neste universo midiático?

O próprio Vattimo (1992:14-15) responde:

Aqui a emancipação consiste mais no desraizamento, que é também, e ao mesmo tempo, libertação das diferenças, dos elementos locais, daquilo que poderíamos chamar, globalmente, o dialecto. Derrubada a ideia de uma realidade central da história, o mundo da comunicação generalizada explode como uma multiplicidade de racionalidades locais [...].

E nesta pluralidade de culturas, no pensamento do autor, viver significa:

uma experiência da liberdade como oscilação entre pertença e desraizamento é uma liberdade problemática, não só porque este efeito dos media não é garantido (...); mas também porque nós mesmos não sabemos ainda muito bem que aspecto tem - custa-nos a conceber esta oscilação como liberdade: a nostalgia dos horizontes fechados, ameaçadores e tranquilizadores ao mesmo tempo, continua ainda radicada em nós, como indivíduos e como sociedade. (1992:16-17) 
De Stuart Hall a Gianni Vattimo, a questão é a confirmação das grandes mudanças relacionadas ao indivíduo, ao mundo em que este vive, à fragmentação da noção de identidade, assumindo que os meios de comunicação são influenciados e, principalmente, possuem influências determinantes nestas alterações, bem como na reorganização do espaço e do tempo.

\subsection{A condição comunicativa contemporânea}

A sensação da existência de uma condição comunicativa, determinante, ou de um conjunto delas, vem ocupando cada vez mais espaço na vida das pessoas. De acordo com o John B. Thompson (2011), a comunicação é um tipo de atividade social que envolve a produção, transmissão e recepção de símbolos e implica na utilização de vários recursos.

Em A Mídia e a Modernidade, Thompson enfatiza a importância de se pensar nos meios em relação aos contextos práticos, nos quais os indivíduos produzem as formas simbólicas. Ele sustenta que o desenvolvimento da mídia transformou a constituição espacial e temporal da vida, criando novas maneiras de ação e interação, não mais ligadas ao compartilhar de um lugar comum.

Thompson defende como argumento principal de sua teoria que:

os meios de comunicação estão inextricavelmente ligados às formas de ação e interação que os indivíduos criam e das quais participam ao usar esses meios e nada ilustra esse ponto mais claramente que as formas múltiplas da ação e interação que foram criadas, ou expandidas e amplificadas, pela comunicação mediada pelo computador online. (2011:10)

A proposta do sociólogo mostra que a evolução dos meios - desde as mais remotas formas de impressão até os mais recentes tipos de comunicação eletrônica - foi uma parte integral do surgimento das sociedades modernas. Este caminhar midiático "se entrelaçou de maneira complexa com um número de outros processos de desenvolvimento que, considerados em sua totalidade, se constituíram naquilo que hoje chamamos de modernidade" (THOMPSON, 2011:24). 
Em sua visão, para compreendermos o impacto das redes comunicacionais e o fluxo de informações, é preciso abandonar a ideia de que os veículos midiáticos servem para transmitir informação e conteúdo simbólico a indivíduos cujas relações com os outros permanecem inalteradas.

Thompson sinaliza para as mudanças contemporâneas na forma de se informar e formar. Para ele, das interações face a face que prevaleciam anteriormente, hoje temos as relações mediadas que, segundo ele, provocam o fenômeno interessante de levar os seres humanos a preferirem, cada vez mais, "buscar informações e conteúdo simbólico em outras fontes [referindo-se à mídia] do que nas pessoas com quem interagem diretamente no dia-adia" (2004:82).

O autor aponta que, além do chamado "boca a boca", outros dois tipos de ligação são produzidos pelo uso da mídia: o que ele chama de "interação mediada", quando usamos um meio técnico para interagir, e a "quase mediada", estabelecida pelo uso de outros como livros, jornais, rádio e televisão. As duas maneiras diferem significativamente do face a face, que constitui grande parte da vida cotidiana.

Além dos tipos definidos, é importante o acréscimo do universo digital, em especial a internet e as redes sociais. Thompson (2011:10) expõe:

quando eu escrevia The Media and Modernity no começo da década de 90, a internet ainda estava engatinhando; se eu estivesse escrevendo o livro hoje, a proliferação das formas de comunicação com base na internet - desde os $e$ mails até o YouTube, o Twitter, o Facebook e toda pletora de outras redes e sites online iria ocupar um lugar proeminente em minha explicação.

O relato do autor no prefácio da $12^{\mathrm{a}}$ edição de A Mídia e a Modernidade demonstra que é importante considerar a revolução tecnológica nas comunicações, que "nenhum estudioso sério da mídia pode ignorar" (2011:10). No entanto, reconhece que a obra, devido à época em que foi escrita, não capta de maneira adequada as características e formas advindas com a rede mundial de computadores.

A questão das relações de poder e sobre como se concentram, não é esquecida pelo teórico que neste sentido dialoga com quatro aspectos: econômico, político, coercitivo e simbólico. Dentre estes poderes, o último, é compreendido como parte cultural, pois nasce das atividades de produção, transmissão e recepção de significados, característica fundamental da 
vida dos indivíduos contemporâneos, que se ocupam com ações de expressão de si mesmos, por meio de imagens/ícones, utilizadas pelos outros.

Thompson ressalta ainda a grande variedade de instituições que assumem um papel historicamente importante na acumulação da informação e dos meios de comunicação. Cita:

instituições religiosas, que se dedicam essencialmente à produção e difusão das formas simbólicas ligadas à salvação, aos valores espirituais e crenças transcendentais; instituições educacionais, que se ocupam com a transmissão de conteúdos simbólicos adquiridos (o conhecimento) e com o treinamento de habilidades e competências; e instituições de mídia, que se orientam para a produção em larga escala e a difusão generalizada de formas simbólicas no espaço e tempo. (2011:43)

Em outra abordagem, Manuel Castells defende que, para situar a questão da condição comunicativa contemporânea, é imprescindível falar de internet, pois "é o tecido de nossas vidas neste momento. Não é futuro. É presente. Internet é um meio para tudo" (2003:255).

Castells chama o atual modelo social de "a sociedade em rede", justamente por acreditar que "ela é - e será ainda mais - o meio de comunicação e de relação essencial sobre o qual se baseia uma nova forma de sociedade que nós já vivemos" (2003:256). Para ele, o momento é caracterizado pela revolução tecnológica, centrada nos espaços digitais, com uma estrutura societária em rede em todos os âmbitos de atividade e com interdependência global.

Em plena era informacional, Castells descreve as características de um sistema em que a realidade em si (ou seja, a existência material/simbólica das pessoas) está imersa por completo em um ambiente de imagens virtuais, no mundo do "faz-de-conta", em que os símbolos não são apenas metáforas, mas contemplam a experiência real, o que ele denomina de Cultura da virtualidade real.

A delimitação deste tipo de sociedade descrita pelo sociólogo como caracterizadora desta época e responsável pelo novo momento da comunicação, aliada às teses de Thompson e Vattimo sobre a função determinante dos meios e sua interferência nas relações e comportamento dos indivíduos, afeta diretamente as instituições consolidadas e tradicionais, caso da escola e as instâncias mediativas. 


\subsection{As mediações no processo comunicacional}

As relações socioculturais contribuem, atualmente, para a proliferação de uma variedade de signos e linguagens que se deparam com o discurso dos media, o que exige, para a compreensão das mensagens veiculadas, inúmeras interações do ser humano, como já descrito por Thompson. A comunicação se torna, portanto, um processo simultâneo e dependente das formações culturais e a mediação, conceito fundamental, atua como coordenadora dessas manifestações.

Dada a extensão e variedade dos Estudos Culturais, identificamos marcas desta perspectiva na obra de Jesús Martín-Barbero, nas elaborações conceituais de Raymond Williams e, em menor medida, na pesquisa clássica de Richard Hoggart, dois autores já citados anteriormente na descrição histórica desta corrente.

Para Martín-Barbero, os processos comunicacionais devem ser analisados sob o contexto sócio-histórico, em uma dialogicidade que conflui para a negociação de sentido, algo que vai se construindo nas relações.

$\mathrm{Na}$ introdução de Dos meios às mediações: Comunicação, Cultura e Hegemonia (1997), afirma que "a comunicação se tornou mais uma questão de mediação, questão de cultura e, portanto, não só de conhecimento, mas, de re-conhecimento" (1997:16).

Essa orientação conduz a um processo comunicativo estreitamente vinculado a práticas cotidianas da vida social, com um deslocamento de olhar que analisa todo o processo e não apenas o emissor ou o receptor da mensagem.

Segundo o autor, os meios de comunicação são deslocados do centro da análise, pois não são mais estudados na orientação funcionalista, como produtores de um sentido unidirecional, capaz de provocar a apatia das massas e com "superpoderes" de manipulação, cujas forças seriam capazes de transformar a cultura em reprodução da indústria cultural.

A expressão indústria cultural, elaborada por Theodor Adorno e Max Horkheimer, pensadores da Escola de Frankfurt, refere-se, de forma sintetizada, à conversão da cultura em mercadoria, ao processo de subordinação da consciência à racionalidade capitalista ocorrido nas primeiras décadas do século XX.

O referido conceito trata do uso de técnicas de comunicação e não dos meios em si. Em outras palavras, significa uma prática social na qual a produção de bens culturais e intelectuais ocorre de acordo com o consumo mercadológico. 
Os cientistas sociais envolvidos nesta corrente de pensamento possuíam um projeto coletivo - em termos filosóficos e políticos, buscavam elaborar uma ampla teoria crítica, além de terem sido responsáveis pela crescente importância dos fenômenos da mídia e da cultura de mercado na formação do modo de vida da atual sociedade.

Por isto, a análise de Martín-Barbero é oposta à visão da Escola de Frankfurt, pois, se para o autor os meios de comunicação e a indústria cultural apresentam uma proposta da qual o público dispõe de forma diversificada, os frankfurtianos os definiram como uma ferramenta de controle e manipulação das massas.

Na concepção barberiana, a recepção midiática é compreendida como um processo de interação, no qual entre o emissor e o receptor existe um espaço de caráter simbólico e representativo preenchido pela mensagem. A comunicação é elaborada por meio de múltiplos fatores e essa diversidade factual interfere em sua recepção.

Postula o autor que "a verdadeira proposta do processo de comunicação e do meio não está nas mensagens, mas nos modos de interação que o próprio meio - como muitos dos aparatos que compramos e trazem consigo seu manual de uso - transmite ao receptor" (2002:55).

A indicação do autor para analisar os processos comunicacionais a partir da cultura pressupõe não centralizar as observações unicamente nos meios, mas ampliar a análise para as mediações. Justamente neste aspecto, ao considerarmos a instância escolar como uma mediadora institucional e o professor como um agente mediador entre o conhecimento e o aluno, estabelecemos a importância da produção de significados e troca de sentidos.

Nesta direção, pontua Martín-Barbero (1996:19):

Os meios de comunicação e as tecnologias da informação significam para a escola em primeiro lugar isto: um desafio cultural, que torna visível a distância cada dia maior entre a cultura ensinada pelos professores e aquela outra aprendida pelos alunos. Pois os meios não só descentram as formas de transmissão e circulação do saber como também constituem um decisivo âmbito de socialização através dos mecanismos de identificação/projeção de estilos de vida, comportamentos, padrões de gosto. E apenas a partir da compreensão da tecnicidade mediática como dimensão estratégica da cultura que a escola pode inserir-se nos processos de mudança que atravessam a nossa sociedade. 
A consideração dos meios como estratégicos no ambiente cultural e a necessidade de um ajustamento das realidades entre os diferentes modos de aprender e apreender em nossa sociedade são fundamentais, sobretudo no jogo dialógico que as linguagens midiáticas estabelecem com os indivíduos e a sala de aula, local propício para a sua manifestação.

Ao revisitar sua obra, Jesús Martín-Barbero (2009:151-152) expõe que as mediações ocorrem em vias práticas e concretas. Ao que chama "mediações comunicativas da cultura", ele destaca quatro que acredita serem fundamentais para o entendimento dessas ações: a tecnicidade, relacionada às tecnologias da informação e comunicação; a institucionalidade, crescente dos meios como instituições sociais e não apenas aparatos; a socialidade, que se refere às atitudes cotidianas de todos os sujeitos sociais em negociações; as novas ritualidades, que estão vinculadas aos novos formatos industriais advindos da tecnicidade.

$\mathrm{O}$ autor reflete sobre a institucionalidade na releitura de sua obra resgatando Jürgen Habermas ${ }^{20}$ no que concerne às transformações dos laços sociais, pensadas em termos de identidade sociocultural, de um novo modo de relação.

Ao tratar do conceito de socialidade, Martín-Barbero também recorre ao modelo frankfurtiano, ao afirmar que vivemos em uma sociedade que não tem centro porque as identidades que eram centralizadoras do sujeito também deixaram de sê-lo. A importante mudança foi reconhecer que a comunicação estava mediando todos os aspectos da vida cultural e social dos povos.

A presença da tecnologia é fundamental neste contexto, entretanto, o diferencial são as relações originadas de sua presença e as novas configurações geradas por ela, como já apontado por Thompson. Nas palavras de Gianni Vattimo (1992), não é o espaço do consenso, mas do conflito, não é o espaço do comum, mas do oscilante, instável e mutável.

\footnotetext{
${ }^{20}$ A defesa da crítica e a argumentação são características centrais do pensamento do alemão Jürgen Habermas. Para o filósofo da segunda geração da Escola de Frankfurt (Teoria Crítica), a razão necessita de um entendimento que promova a interação social e a emancipação humana.
} 
2.5.1 Mediação tecnológica: as novas alfabetizações

Na visão de Guillermo Orozco Gómez, a “mediação tecnológica” impacta tudo aquilo que toca: "não se trata de negar nem de diminuir ou simplesmente relativizar esse impacto. Trata-se de vê-lo como um impacto importante, mas que necessariamente compete com outros" (2006:86). Neste sentido, Orozco ressalta o abandono da noção de que as mediações vêm só dos meios ou são de certa maneira sua extensão. $\mathrm{O}$ autor as compreende como processos estruturantes advindos de inúmeras fontes e incidindo nos processos de comunicação.

Orozco enfatiza duas tendências crescentes na condição comunicativa contemporânea, que são interdependentes e paralelas: a "mediatização" e "audienciação".

A primeira é resultado da expansão dos meios de comunicação e tecnologias de informação, chamada por ele de dependência mediática múltipla, envolvendo tipos cognitivos, emocionais e práticos como fator distintivo das sociedades atuais em relação às anteriores. A mediatização se apresenta como um desafio da vida cotidiana, em todos os aspectos, do público ao privado, tornando uma ação irreversível para as relações.

O autor cita como exemplo o estudo sobre a televisão, que é caracterizada de maneira particular em cada país; para tanto, propõe reflexões sobre como usar o que temos, enfim, o que nos é ofertado pelos meios, de maneira inteligente, produtiva, crítica e independente que contribua para o desenvolvimento das audiências, as quais constituem o segundo aspecto: a "audienciação"

Para o estudioso, esse fenômeno é fruto da crescente centralização dos meios como referências dos indivíduos e a mediação é um processo estruturante que orienta a interação das audiências (na origem do termo, está ligada ao universo jurídico e indica receber e emitir informações) as quais passam a dar sentido aos referentes midiáticos.

As novas telas (termo usado pelo autor para designar novos aparatos tecnológicos, como o computador e celular) permite que o receptor se torne também produtor, ou melhor, usuário. O transitar do receptor ao receptor-emissor, fruto da convergência, multiplica formatos, linguagens e estética nestes meios comunicacionais.

Como "uma nova produção cultural": é assim que Orozco chama o produto do intercâmbio entre novas telas, audiências e usuários. "Dicho de outra manera, cada vez más los referentes claves del intercambio social contemporâneo son productos audiovisuales, mediados y tecnificados a los cuales se accede desde alguna pantalla y suporte tecnológico" (2009:6). 
Essa produção não parte do ponto zero; ela vem de contextos anteriores formados por meios tradicionais, porém não é manifesta por estas fontes clássicas. O autor justifica, assim, com base no surgimento de novos aparatos e tecnologias, a necessidade de novas alfabetizações.

[...] las nuevas alfabetizaciones, que de hecho tienen lugar aunque de manera fortuita o no cosnciente, demandan com urgência de "nuevas educaciones", entendidas como otras estratégias para ubicar de manera más adecuada a todos em este intercambio múltiple, cresciente y a veces caótico em el que nos encontramos. (OROZCO, 2009:7)

O termo "usuário", utilizado por Orozco, é criticado por Hugo Assmann (2000) já que, para este estudioso, a palavra não expressa adequadamente a relação entre humanos e máquinas, por isto prefere utilizar em seu lugar o conceito de sociedade aprendente ${ }^{21}$. Assmann enfatiza que a espécie humana alcançou hoje uma fase evolutiva inédita na qual os aspectos "cognitivo e relacional" da convivência se "metamorfoseiam" com rapidez nunca antes experimentada.

O autor explana sobre a metamorfose do processo de aprendizado e afirma que a instrumentalização e a reflexão não são alternativas contrapostas, mas racionalidades conjugáveis e complementares. Pressupõe que a resistência de muitos professores a usar livremente as novas tecnologias na pesquisa pessoal e na sala de aula "tem muito a ver com a insegurança derivada do falso receio de estar sendo superado, no plano cognitivo, pelos recursos informáticos" (2000:8).

Quanto à crítica à razão instrumental, o autor ressalta ser um desafio permanente, porém, para evitar mal-entendidos, esclarece (2000:10):

Nada de redução do Lógos à Techné. Mas, doravante, já não haverá instituição do Lógos sem a cooperação da Techné. As duas coisas se tornaram inseparáveis em muitas das instâncias - não em todas, é claro - do que chamamos aprender e conhecer. Estamos desafiados a assumir um novo enfoque do fenômeno técnico. Na medida em que se tornou co-estruturador de nossos modos de organizar e configurar linguagens, penetrou também nas formas do nosso conhecimento.

\footnotetext{
${ }^{21}$ Cf. ASSMANN, Hugo. Reencantar a Educação - Rumo à Sociedade Aprendente. Petrópolis: Vozes, 1998. $4^{\mathrm{a}}$ ed. 2000.
} 
Em resumo, o autor defende que as novas tecnologias têm um papel ativo e estruturante nas formas de aprendizagem e conhecimento, daí a importância de aproveitá-las ao máximo, mas sem desconsiderar as implicações antropológicas e epistemológicas da relação entre seres humanos e maquinário.

Retomando Jesús Martín-Barbero, "a tecnologia remete, hoje, não a alguns aparelhos, mas sim a novos modos de percepção e de linguagem, a novas sensibilidades e escritas" (2006:54).

Orozco (1994:20), apoiado em filósofos da educação, aponta que as influências da mediação dos meios comunicacionais seguem ao menos em três direções:

Habilidades, conhecimentos e crenças. As habilidades implicam um saber prático, o saber fazer. O conhecimento implica um saber mais conceitual, um saber o quê. E as crenças fundamentalmente significam crer em algo que possa ser independentemente do saber acerca desse algo ou de saber fazê-lo.

Em nossa perspectiva de discussão, ao trazermos as reflexões de Martín-Barbero, Orozco Gómez e Hugo Assmann desejamos elucidar a visão dialógica dos processos comunicacionais, considerando as mediações tecnológicas, em um movimento que interfere e re-configura, a cada instante, as mensagens e resulta em novos modelos de interpelação do sujeito.

Enfim, como ressalta Mauro Wilton de Sousa (1999), talvez a influência da postura funcionalista em comunicação na atividade educacional, além da resistência provocada diante do significado do uso dos meios, esteja na própria definição de como diferentes formas de saber podem ou não concorrer com a comunicação midiática na relação ensino/aprendizagem.

Entretanto, se estamos tratando de novos sujeitos inseridos em um novo modelo social, a distância das gerações na relação docente/discente também precisa ser considerada.

2.5.2 Mediações sociais: dos nativos aos imigrantes digitais

A presença das tecnologias na primeira década do século XXI foi condição sine qua non para o desenvolvimento de diversas áreas. A metáfora que envolve os conceitos de nativos e imigrantes digitais representa as preocupações do americano Marc Prensky quanto ao processo de aprendizagem de crianças e jovens. 
No primeiro grupo, de acordo com Prensky, estão os jovens que nasceram no período em que a internet já existia, que aprendem sozinhos com as tecnologias e as fazem uma verdadeira extensão de si mesmos. O segundo grupo é formado pelos imigrantes, ou seja, indivíduos que não nasceram no mundo digital e que em determinada altura se sentiram atraídos por ele.

Para estes, serão necessárias a adaptação ao ambiente e a aquisição de novas aprendizagens, situação contrária à dos nativos digitais, para quem a evolução tecnológica fará sempre parte do processo natural de desenvolvimento.

Prensky destaca a distância entre gerações, afinal, "nativos e imigrantes digitais são termos que explicam as diferenças culturais entre os que cresceram com a era digital ou não" (2010:39). A noção de que os jovens vivem na manifesta $e$-life é apontada pelo americano como um dos grandes desafios da escola formal na medida em que os alunos que se naturalizaram com as novas tecnologias se transformaram em verdadeiros "especialistas".

Além de processarem com maior rapidez as informações, os nativos dão primazia às imagens, enquanto os imigrantes ao texto. A inserção de suportes tecnológicos no ambiente educacional, como lousas digitais e laboratórios de informática, não é garantia de sucesso na prática pedagógica, destaca Marc Prensky (2010:42):

Introduzir novas tecnologias na sala de aula não melhora o aprendizado
automaticamente, porque a tecnologia dá apoio à pedagogia, e não vice-
versa. Infelizmente, a tecnologia não serve de apoio para a velha aula
expositiva, a não ser da forma mais trivial, como passar fotos e filmes. Para
que a tecnologia tenha efeito positivo no aprendizado, os professores
precisam primeiro mudar o jeito de dar aula. No meu livro, uso o termo
"Pedagogia de Parceria" para definir esse novo método, no qual a
responsabilidade pelo uso da tecnologia é do aluno - e não do professor.

Não se colocando como apocalíptico e anunciado o fim da escola formal, o autor acredita que a sala de aula sim, como a conhecemos hoje, não servirá para ensinar.

O que o pensamento de Prensky nos apresenta é a exigência constante de ressignificação para esses imigrantes digitais, em termos de ensino/aprendizagem, de suas metodologias em sala de aula, para se ambientarem junto aos novos alunos. É admissível que os professores estejam inclusos entre os imigrantes ou em via de passagem a nativo, dependendo de sua faixa etária, por isso a necessidade de rever as ações no universo escolar. 


\subsubsection{Das mediações ao estudo da língua}

Após o entendimento do papel das mediações (tecnológicas e sociais) no processo comunicacional, do conceito de Jesús Martín-Barbero, perpassando as novas alfabetizações de Guillermo Orozco Gómez, eclodindo nas distinções entre nativos e imigrantes digitais de Marc Prensky, voltamo-nos neste momento ao termo que nomeia esta dissertação, a linguagem.

O cenário contemporâneo, quanto ao complexo aparato tecnológico, convergente e interativo, parece recorrer cada vez mais às novas maneiras de compreender os desafios linguareiros, desdobramentos e estratégias que compõem a ampla composição de sentidos, ratificando a assertiva de que a base da comunicação é fundamentalmente linguagem sob diversas configurações de códigos e signos.

Mikhail Bakhtin (1895-1975) propôs um entendimento radical desses processos, de caráter sócio-histórico: ele afirma que o significado é formado devido às múltiplas interações entre indivíduo, cultura e história. Explica que a interação não pode ser lida como uma simples tradução de ligações comunicativas entre os sujeitos: "A interação verbal constitui a realidade fundamental da linguagem" (BAKHTIN, 1989:109).

Em nosso trabalho com jornalismo e publicidade, este conceito é necessário para o direcionamento das estruturas teóricas e ocorrências práticas de pesquisa. Utilizamos a concepção de Bakhtin, ou do Círculo de Bakhtin, como ficou conhecido o seu grupo, para quem a linguagem consiste em um constante processo de interação mediado pelo diálogo - e não apenas como um sistema autônomo.

As fundamentações teóricas deste trabalho se baseiam na assertiva de que a linguagem está no centro do processo comunicacional, levando em consideração as dinâmicas sistêmicas, mercadológicas e das organizações midiáticas. O entendimento é de que, a partir dela, linguagem, em suas formas simbólicas, os chamados contratos comunicacionais são firmados aos receptores/emissores envolvidos pelo discurso da mídia. Em circulação, estas formações discursivas moldadas com arranjos, diálogos múltiplos e (des) ajustes garantem legitimidade aos contornos sociais por onde passam.

Como a disciplina dos docentes (sujeitos) analisados é a Língua Portuguesa, consideramos necessário pontuar brevemente importantes mudanças ocorridas no Brasil em relação ao trabalho com a língua, a partir da publicação de documentos norteadores. 


\subsection{Língua Portuguesa: redefinição dos Parâmetros Curriculares Nacionais}

As inúmeras alterações no contexto sócio-histórico brasileiro, na segunda metade do século XX, solicitaram redefiniçõoes de metodologias pedagógicas, sobretudo no tratamento da linguagem. Essas mudanças aconteceram a partir da década de 80 no ensino de Língua Portuguesa e, posteriormente, na década de 90 com a implantação dos Parâmetros Curriculares Nacionais (PCNs), material norteador do ensino nacional e dos docentes de todas as disciplinas.

A publicação das orientações para a referida disciplina escolar, em relação aos conteúdos, trouxe conceitos acerca da adoção do texto como unidade de sentido. Essas observações culminaram em aberturas no espaço educativo e no agir pedagógico dos professores e também em pesquisas sobre as aplicações das diversidades textuais.

Uma vez que as práticas de linguagem são uma totalidade e que o sujeito expande sua capacidade de uso da linguagem e de reflexão sobre ela em situações significativas de interlocução, as propostas didáticas de ensino de Língua Portuguesa devem organizar-se tomando o texto (oral ou escrito) como unidade básica de trabalho, considerando a diversidade de textos que circulam socialmente. Propõe-se que as atividades planejadas sejam organizadas de maneira a tornar possível a análise crítica dos discursos para que o aluno possa identificar pontos de vista e eventuais preconceitos neles veiculados. (BRASIL, 1998:58-59)

Considerar as inúmeras mensagens que circulam na sociedade e estabelecer situações significativas de interlocução em sala de aula se tornaram atitudes primordiais para o processo educacional, ainda mais em uma sociedade caracterizada pela presença das tecnologias e multimeios.

Em nossa investigação, o objeto, ou seja, as linguagens da comunicação inseridas no ambiente formal de ensino/aprendizagem, e os sujeitos (docentes de Língua Portuguesa) encontram-se envolvidos com o estudo dos processos linguajeiros. Sendo assim, a compreensão textual, tal como proposta pelos PCNs, requisita a retomada de conceitos fundamentais entre os professores da área nos diálogos com os discentes. 
É o caso da compreensão de gêneros que, nesta dissertação, são lidos como uma espécie de "agrupamento" de textos com algumas características comuns, embora heterogêneos.

Para Helena Nagamine Brandão, a classificação do discurso em gêneros é necessária para fins de organização, isto é, "em meio à heterogeneidade dos textos que nos defrontamos no campo da linguagem, é necessário identificá-los, organizá-los, ordená-los na tentativa de melhor compreendê-los” (2003:19). A autora expõe que, no campo da didática da língua, aqueles que trabalham necessariamente com textos e têm por objeto natural de reflexão "os discursos dos alunos, das mídias, da literatura, têm sido obrigados a se colocarem questões relativas às classificações desses textos e discursos" (2003:22).

Brandão (2003) nomeia estas organizações textuais de tipologização e aponta quatro tipos: a) a tipologia funcional - estudo das funções do discurso, na perspectiva de Roman Jakobson; b) a enunciativa, que trata da influência das condições de enunciação (interlocutores, lugar e tempo) sobre a organização do tempo, nas perspectivas de Émile Benveniste e Jean Paul Bronckart; c) a cognitiva, que se refere à organização cognitiva, prélinguística, certa sequência narrativa, descritiva etc. (neste grupo estaria o modelo de análise textual do discurso de Jean Michel Adam); d) a sociointeracionista, para a qual a visão de Mikhail Bakhtin é apropriada.

\subsubsection{Linguagem e gênero: conceitos direcionadores}

Ao tratar da enunciação, importante apontar que, para Mikhail Bakhtin, a natureza dialógica é um produto da relação entre dois indivíduos organizados socialmente e que, portanto, ocorre em um contexto socioideológico.

Sendo assim, o sentido não está localizado na palavra, no sujeito ou nos interlocutores - ele é resultado da ligação entre locutor e receptor, produzido por meio de signos. Na visão do autor russo, "a verdadeira substância da língua não é constituída por um sistema abstrato de formas linguísticas, nem pela enunciação monológica isolada, nem pelo ato psicofisiológico de sua produção, mas pelo fenômeno social da interação verbal realizada através da enunciação" (1992:123).

O caráter de diálogo reflete correntes interlocutivas que se compõem e decompõem numa dimensão social complexa. Não existe uma instância fundadora: toda linguagem é derivada de outra numa espécie de retroalimentação. Para o autor, é nela que a comunicação social aparece mais clara, pois a palavra é o modo mais puro de relação. 
A palavra é o fenômeno ideológico por excelência. A realidade toda da palavra é absorvida por sua noção de signo. A palavra não comporta nada que não esteja ligado a esta função, nada que não tenha sido gerado por ela. A palavra é o modo mais puro e sensível de relação social. (BAKHTIN, 1992:36)

A noção de constituição dos sentidos não se refere apenas à capacidade nomeadora, mas também às interfaces históricas e sociais. Neste momento, é oportuno resgatarmos o filósofo Ludwig Wittgenstein, membro da corrente de tradição pragmática da filosofia analítica inglesa, apenas para reforçar o conceito utilizado, segundo o qual o importante é a superação do olhar metafísico da linguagem como instância nominativa e a adoção da ideia de jogo entre emissor e receptor.

Para Wittgenstein, o sentido não se constitui no "cá", na capacidade puramente nomeadora das palavras, nem no "lá", no plano da natureza, e sim no jogo entre o lugar da linguagem e a organização da sociedade. As significações nascem no movimento entre o "cá" e o "lá" em função de contextos e usos. "Todo signo, sozinho, parece morto. O que lhe confere vida? - Ele está vivo no uso" (2005:173). De acordo com o filósofo, a linguagem não é um mecanismo fixo, fechado, ela está em permanente mudança, "podemos dizer, novos tipos de linguagens, novos jogos de linguagem, surgem, outros são esquecidos. A expressão ‘jogo de linguagem’ deve salientar que falar uma língua é parte de uma atividade” (2005:27).

$\mathrm{Na}$ visão do autor, a própria língua apresenta inúmeras variações, que seriam sublinguagens. Elas permitem a elaboração de consensos comunicacionais, ou seja, a possibilidade de transição de conceitos, palavras e ideias. $\mathrm{O}$ autor entende o consenso como algo provisório, que pode se abalar a qualquer momento.

Os “jogos” de Wittgenstein e o dialogismo de Bakhtin são conceitos direcionadores da pesquisa, principalmente por estarem ligados aos processos do jornalismo e publicidade no fazer em sala de aula.

Antes de verificar a dimensão das ações pedagógicas no contexto escolar em relação às referidas linguagens, resgatamos a noção histórica de gênero, conceito já explicitado anteriormente por Helena Brandão e que, desde os gregos Platão e Aristóteles, é uma constante preocupação. A distinção de lírico, dramático e épico, na concepção platônica, como as três formas fundamentais da Literatura é uma classificação válida até os dias atuais. 
Eles seriam formados, respectivamente, por obras em que: somente o autor fala; a fala se restringe aos personagens; ambos têm direito ao uso da palavra.

A retórica antiga também classificou três tipos discursivos, de acordo com as circunstâncias em que são pronunciados: deliberativo, judiciário e epidítico. O primeiro, dirigido a uma espécie de auditório, assemelha-se ao discurso político; no judiciário, o orador acusa ou defende uma ideia; o último é uma mensagem de elogio ou repreensão às atitudes dos cidadãos.

Bakhtin em sua obra Estética da Criação Verbal, expõe a oposição entre a concepção da língua e os meios.

Para o autor, qualquer enunciado (oral ou escrito) considerado isoladamente é individual, mas cada esfera de utilização da língua elabora seus tipos relativamente estáveis de enunciados, sendo isso o que denomina gêneros do discurso. Segundo o russo, estes devem ser compreendidos como um modo de conceber a vida, formados por três importantes componentes: conteúdo temático, estilo e construção composicional, diretamente ligados aos valores e funções sociais do processo de comunicação.

O querer dizer do locutor se realiza acima de tudo na escolha de um gênero do discurso. Essa escolha é determinada em função da especificidade de uma dada esfera da comunicação verbal, das necessidades de uma temática (do objeto de sentido), do conjunto constituído de parceiros. (BAKHTIN, 2000:231)

Valendo-nos da ótica bakhtiniana, é possível afirmar que, apesar de um conhecimento abrangente da língua, alguns indivíduos acabam desamparados em certas situações comunicacionais por não exercerem o domínio, na prática, de determinados gêneros em uma dada esfera.

Bakhtin distingue os gêneros do discurso em dois tipos. Os primários ele define como "simples": podem ser exemplificados como diálogo, carta, situações de interação face a face, e são constituídos em contextos de comunicação ligados ao cotidiano. Dos secundários, que ele considera mais "complexos", podemos citar como exemplos: o romance, o teatro, o discurso científico, o discurso ideológico; a complexidade aparece em circunstâncias de uma comunicação cultural, relativamente mais evoluída, principalmente escrita; acrescenta: “durante o processo de formação esses gêneros absorvem e transmutam os gêneros primários" (2000:281). 
Em outras palavras, a conceituação bakhtiniana acerca da questão genérica é de grande valia para os diálogos com a pesquisa. No entanto, incluímos pensadores contemporâneos que analisam o assunto na instância escolar caso da professora Helena Nagamine Brandão e dos agrupamentos propostos pelos teóricos de Genebra. Estes estudiosos, por sua vez, fundamentados em Bakhtin, elaboram diversificadas organizações e modos de leitura da prática pedagógica quanto à tipologização dos gêneros na escola.

\subsubsection{Os gêneros na escola}

Aprofundaremos nosso estudo com relação às especificidades destes textos no ambiente escolar baseando-nos também em dois pesquisadores da chamada "Escola de Genebra": Joaquim Dolz e Bernard Schneuwly. Os fatores determinantes para a escolha foram: a utilização desta perspectiva teórica na Proposta Curricular de Língua Portuguesa do município de Barueri; a Olimpíada de Língua Portuguesa (OLP), iniciativa do Ministério da Educação (MEC), inclusa entre as ações do Plano de Desenvolvimento da Educação (PDE), valer-se dos aportes de Dolz e Schneuwly.

Quanto às habilidades leitora e escritora no ambiente educacional, resgatamos Helena Nagamine Brandão para quem o professor não pode perder de vista a dimensão heterogênea que a noção conceitual implica. Ela recorre a Bakhtin nos quesitos produção e leitura textual, considerando o que o pensador russo chama de forças centrípetas e forças centrífugas:

Enquanto traços marcados pela regularidade, pela repetibilidade, o gênero é relativamente 'estável', mas essa estabilidade é constantemente marcada por pontos de fuga, por forças que atuam sobre as coerções genéricas. Em determinados gêneros, essa tensão se faz marcar de maneira mais acentuada, em outros, não. Por exemplo, uma notícia $X$ e um texto literário, em que a primeira, a quase fixidez dos seus elementos constitutivos torna esse gênero mais estável: há quase que se ter sempre um quem, o quê, o como, o por quê, o quando, o onde. $\mathrm{O}$ professor tem que estar atento a essa dupla face que o gênero apresenta: forças de concentração atuando ao lado de forças de expansão. (BRANDÃO, 2003:38)

Brandão trabalha com o pressuposto interacionista, segundo o qual a atividade com a língua possui o objetivo de desenvolver a competência comunicativa do educando. Sob este 
entendimento, o aluno é exposto a diferentes tipos discursivos para aprender suas especificidades, identificá-los e incluí-los em sua prática social.

Em Gêneros orais e escritos na escola (2004), Joaquim Dolz e Bernard Schneuwly os descrevem, do ponto de vista do uso e aprendizagem, como mega-instrumentos fornecedores de suportes para atividades nas situações de comunicação. Entretanto, essa metáfora abre espaço para questionamentos: o risco da noção instrumental de língua. Por isto, os teóricos discorrem que a particularidade da inclusão destes textos no ambiente escolar é pelo fato deles sofrerem um desdobramento, no qual deixam de ser apenas instrumento comunicacional e passam também a ser objeto de ensino.

Dolz e Schneuwly postulam que os "gêneros escolares", como nomeiam, são verdadeiros "produtos culturais da escola, elaborados como instrumentos para o desenvolvimento e avaliação da escrita dos alunos" (2004:66). Recorrem também a Bakhtin quanto às três dimensões essenciais formadoras do gênero: 1) os conteúdos que se tornam dizíveis por meio dele; 2) a estrutura (comunicativa) particular dos textos pertencentes a ele; 3) as configurações específicas das unidades de linguagem.

Nesta proposta de ensino, a escola é concebida como uma espécie de lugar da comunicação e as atividades geradas neste espaço são vistas como momentos de produção/recepção textuais. "A situação de comunicação é vista como geradora quase automática do gênero, que não é descrito, nem ensinado, mas aprendido pela prática da linguagem escolar, por meio de parâmetros próprios às situações e às interações com os outros" (DOLZ e SCHNEUWLY, 2004:83).

Os professores de Genebra associam as práticas linguajeiras às aquisições acumuladas pelos grupos sociais. As estratégias de ensino tornam-se, então, fundamentais e devem ser compreendidas como intervenções que favorecem a progressão dos alunos em diversas situações. Essas atividades passam a ser realizadas em "cenários comunicativos" que os autores denominam de "tipos ideais", formas de representação da realidade, ou seja, verdadeiros simulacros que não dependem das ações sociais, mas da própria realidade.

Quanto às atividades pedagógicas, Dolz e Schneuwly elaboraram uma progressão organizada que chamam de "agrupamentos dos gêneros orais e escritos", totalizando cinco classificações da ordem do narrar, relatar, argumentar, expor e descrever (ver quadro 2). E definem uma sequência didática para a inserção do trabalho com os gêneros no ambiente escolar por meio de módulo, situação inicial e produção final (ver quadro a seguir). 


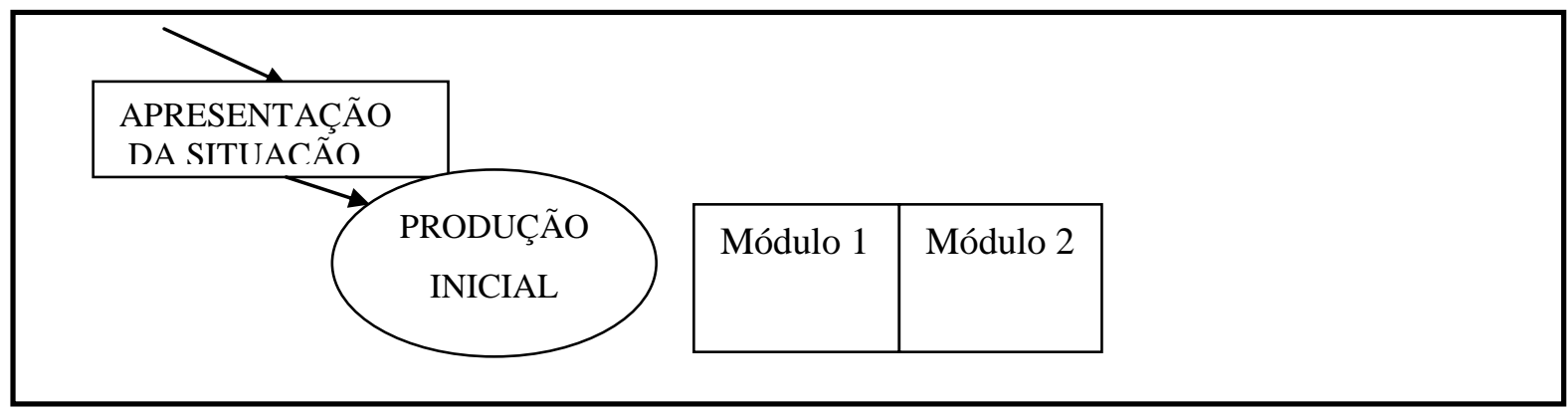


Agrupamento provisório de gêneros proposto por Dolz e Schneuwly (Quadro 2)

Domínios sociais de Comunicação

Aspectos tipológicos

Exemplos de Gêneros Escritos e Orais

Capacidades de Linguagem

Dominantes

Cultura literária ficcional

Narrar

Mimese da ação através da criação da intriga no domínio verossímil

Documentação e memorização das ações humanas

Relatar

Representação pelo discurso de experiências vividas, situadas no tempo

Discussão de problemas sociais controversos

Argumentar

Sustentação, refutação e negociação de tomada de posição

Transmissão e construção de saberes Expor

Apresentação textual de diferentes formas dos saberes

Instruções e prescrições

Descrever ações

Regulação mútua de comportamento
Conto maravilhoso; Conto de fadas; Fábula; Lenda; Narrativa de aventura; Narrativa de ficção científica; Narrativa de enigma; Narrativa mítica; Sketch ou história engraçada; Biografia romanceada; Novela fantástica; Conto; Crônica Literária; Adivinha; Piada.

Relato de experiência vivida; Relato de uma viagem; Diário íntimo; Testemunho; Anedota ou caso; Autobiografia; Curriculum vitae; Notícia; Reportagem; Crônica social; Crônica esportiva

Histórico; Relato histórico; Ensaio ou perfil biográfico; Biografia.

Textos de opinião; Diálogo argumentativo; Carta de leitor; Carta de reclamação; Carta de solicitação; Deliberação informal; Debate regrado; Assembleia; Discurso de defesa (Advocacia); Discurso de acusação (Advocacia); Resenha crítica; Artigos de opinião ou assinados; Editorial; Ensaio.

Texto expositivo (em livro didático); Exposição oral; Seminário; Conferência; Comunicação oral; Palestra; Entrevista de especialista; Verbete; Artigo enciclopédico; Texto explicativo; Tomada de notas; Resumo de textos expositivos e explicativos; Resenha; Relatório científico; Relatório oral de experiência.

Instruções de montagem; Receita; Regulamento; Regras de jogo; Instruções de uso; Comandos diversos; Textos prescritivos. 


\subsubsection{Os gêneros digitais}

O modelo social contemporâneo exige a adoção de gêneros textuais emergentes no contexto da tecnologia digital, por uma questão de interação do indivíduo com esta nova condição comunicativa da sociedade. Em Hipertexto e gêneros digitais (2005), o professor Luiz Antônio Marcuschi trata de uma série de textos que surgiram com a internet e que interferem na maneira de se comunicar dos cidadãos do século XXI.

Marcuschi (2005:14) aponta três aspectos que considera fundamentais para a análise destes tipos de texto: 1) o seu desenvolvimento e uso cada vez mais generalizado; 2) suas peculiaridades formais e funcionais, não obstante terem eles contrapartes em gêneros prévios; 3) a possibilidade que oferecem de se rever conceitos tradicionais, permitindo repensar nossa relação com a oralidade e escrita. Assim, esse "discurso eletrônico", como o autor nomeia, permite analisar o efeito das tecnologias na linguagem e vice-versa.

Neste estudo, são classificados 12 tipos textuais que circulam no mundo virtual, entre eles: o bate-papo (em programas tipo MSN Messenger), vídeo-conferência interativa, o $e$ mail, o endereço eletrônico (seja o pessoal ou para a home page, portal, página, cada um tem características típicas) e o weblog (blogs, diários virtuais).

Marcuschi, com base em Davi Cristal em Linguagem e a Internet, sobre o uso destes gêneros, destaca algumas características: 1) do ponto de vista dos usos da linguagem: temos uma pontuação minimalista, uma ortografia um tanto bizarra, abundância de siglas, abreviaturas convencionais, estruturas frasais e uma escrita semi-alfabética; 2) do ponto de vista da natureza enunciativa dessa linguagem: integram-se mais semioses do que usualmente, tendo em vista a natureza do meio com participação mais intensa e menos pessoal; 3) do ponto de vista dos gêneros realizados: a internet transmuta de maneira bastante complexa com os já existentes, desenvolve alguns realmente novos e mescla vários outros.

O fato inconteste é que a internet e todos os gêneros a ela ligados são eventos textuais fundamentalmente baseados na escrita. Na internet, a escrita continua essencial apesar da integração de imagens e sons. Por outro lado, a ideia que hoje prolifera quanto a haver uma "fala por escrito" deve ser vista com cautela, pois o que se nota é um hibridismo mais acentuado, algo nunca visto antes, inclusive com o acúmulo de representações semióticas. (MARCUSCHI, 2005:19) 
Ainda em relação à escrita no espaço digital, não podemos deixar de mencionar a importância que o hipertexto adquiriu, de acordo com Pierre Lévy (1993:33), que o define a partir de duas perspectivas: a técnica e a funcional. “[...] tecnicamente, é um conjunto de nós ligados por conexões. Os nós podem ser palavras, páginas, imagens, gráficos ou partes de gráficos, sequências sonoras, documentos complexos que podem eles mesmos ser hipertextos".

Neste aspecto, a afirmação de que é possível ler o mundo por meio dele faz sentido. Retomando o conceito de Paulo Freire, apresentado no capítulo 1, com o hipertexto, a chamada "leitura de mundo" tornou-se virtualmente possível. Na realidade que circunscreve o leitor de Freire, ocorre uma ampliação. Se para ler/entender a palavra, é necessário saber fazêlo com o mundo, conforme apregoava o educador, o hipertexto consolida este processo na medida em que viabiliza a compreensão do leitor pela exploração de informações muitas vezes inacessíveis sem os recursos da internet.

\subsection{Comunicação: do mundo da notícia ao universo imagético da publicidade}

A partir das definições conceituais de linguagem, gêneros e de suas incursões no ambiente de ensino, trataremos especificamente, neste tópico, da explanação do objeto de pesquisa propriamente dito: as linguagens jornalísticas e publicitárias.

Defendemos a assertiva de que, na sociedade globalizada do século XXI, a comunicação desempenha papel fundamental na vida dos indivíduos, como destaca Maria Aparecida Baccega (1998:116): “a comunicação exerce hoje o papel central para onde convergem os conflitos que, ali trabalhados, 'espetacularizados', ressignificados etc., acabam por fazer dos meios de comunicação uma importante instituição que 'leva a pensar', 'que educa"'.

Para a autora, a função básica de transmitir informação, creditada aos meios, cede espaço também à elaboração do conhecimento e disseminação dos saberes, abarcando, a ideia de transitar "do mundo editado à construção do mundo" (2011:11). Seguindo este pensamento, a edição é um processo que necessita ser considerado: 
O mundo é editado, ou seja, ele é redesenhado num trajeto que passa por centenas, às vezes, milhares de mediações, até que se manifeste no rádio, na televisão, no jornal, na cibercultura. Ou na fala do vizinho e conversa dos alunos. As instituições e pessoas deste trajeto selecionam o que vamos ouvir, ver ou ler; fazem a montagem do mundo que conhecemos. (2011:11)

Assim, o saber em sua aquisição e expressão é mediado e, como anteriormente destacado, editado por formas e veículos comunicacionais. Nas palavras de Mauro Wilton de Sousa (1999:11):

Essa hegemonia contemporânea da comunicação. Através de diferentes suportes da imagem eletrônica, e ante a expansão lenta e socialmente desigual das condições de acesso à comunicação pela escrita, acaba sendo fonte de novos conflitos, não só de veículos de comunicação mediados pela imagem eletrônica ou escrita, mas na caracterização e legitimação das diferentes formas do saber social advindos da presença mediadora desses mesmos veículos de comunicação.

Entre os "editores da realidade", cabe ao jornalismo, mais do que a qualquer outro formato de produção midiática, o caráter de produção de saber, pois, ao mostrar o acontecimento factual ao público por meio de contextualizações e problematizações, acaba por dispor a possibilidade do pensar sobre o noticiado.

Eugênio Bucci e Maria Rita Kehl, em Videologias: ensaios sobre a televisão, pensam o jornalismo como uma comunicação voltada à emancipação:

uma comunicação voltada à informação, para a formação e educação do povo para a cidadania, função essa bastante cara aos filósofos do século das luzes, inventores da ideia de opinião pública. O jornalismo é concebido como uma função mediadora do espaço público, como veículo de argumentos mais ou menos racionais, isto é, que dialoguem entre si a partir dos pressupostos da razão. (2004:135)

Bucci, o entende como a função humana de narrar a própria aventura aos outros, ou seja, "é sempre um discurso de um sujeito sobre um segundo sujeito (sua fonte ou seu personagem) para um terceiro sujeito, o público" (2004:135). 
O autor, no trato da ética da informação objetiva, fundada na verdade dos fatos e/ou da busca por ela, expõe que estamos diante de grandes desafios e destaca: "a produção do público enquanto massa e o entrelaçamento do relato factual às técnicas de ficção, quer dizer, a fusão da reportagem com o entretenimento" (2004:136).

$\mathrm{Na}$ visão dele, esta fusão entre o acontecimento e o ato de entreter na produção jornalística provoca um distanciamento dos seus primeiros objetivos funcionais, dos séculos XVIII e XIX, fortemente influenciados pela narrativa literária. Segundo o autor, neste período, o próprio espaço público recebia influências dos saraus literários. Contudo, esse movimento era uma expressão dos cidadãos reunidos com direito à informação e com vistas a uma educação emancipatória.

Ao abordar a dualidade entre real e ficcional, o autor resgata o conceito marxista de mercadoria, sobretudo em relação ao público/receptor:

\footnotetext{
À medida que o público se revela ele mesmo mercadoria, passível de ser vendido ao anunciante, o que será decisivo para a transformação do jornalismo em indústria, os meios de comunicação se dedicam mais e mais a ampliar o seu público, não mais como cidadãos reunidos, mas cada vez mais como cidadãos anônimos, dispersos de si, mas, compactados enquanto massa. (BUCCI, 2004:136)
}

A sustentação da ideia de que o jornalismo resiste e traz em seu discurso a pretensão de conter, sistematizar e representar, de forma neutra, a objetividade dos fatos é descartada com a televisão. "Como se essa neutralidade fosse possível”, afirmou Eugênio Bucci: “A ilusão do discurso jornalístico é descrever a realidade sem nela interferir. Foi assim que encontrou na tela da TV um lugar para inserir sua autoridade" (2004:30).

Ainda sobre a definição do jornalismo, Luiz Beltrão (1992) descreve-o como informação de fatos correntes, "devidamente interpretados e transmitidos periodicamente à sociedade, com o objetivo de difundir conhecimentos e orientar a opinião pública, no sentido de promover o bem comum" (1992:67).

Beltrão propôs a primeira classificação dos gêneros no Brasil em relação ao impresso, no final da década de 60. Sua divisão, de caráter funcionalista, indicou três categorias: informativa, interpretativa e opinativa. 


\begin{tabular}{|l|l|}
\hline \multicolumn{1}{|c|}{ QUADRO 1 } & \multicolumn{1}{|c|}{ CLASSIFICAÇãO - Luiz Beltrão } \\
\hline & a) Notícia \\
1. Jornalismo informativo & b) Reportagem \\
& c) História de interesse humano \\
& d) Informação pela imagem \\
\hline & a) Editorial \\
2. Jornalismo opinativo & b) Artigo \\
& c) Crônica \\
& d) Opinião ilustrada \\
& e) Opinião do leitor \\
\hline 3. Jornalismo interpretativo & a) Reportagem em profundidade. \\
\hline
\end{tabular}

José Marques de Melo (2003), em seu livro Jornalismo Opinativo, trata apenas de dois gêneros - informativo e opinativo, mas, em revisão de sua proposta (2010), com Francisco de Assis, em Gêneros jornalísticos no Brasil acrescenta mais três: interpretativo, utilitário e diversional.

\begin{tabular}{|l|l|}
\hline QUADRO 2 & CLASSIFICAÇÃO-Marques de Melo \\
\hline \multirow{4}{*}{ 1. Gênero informativo } & a) Nota \\
& b) Notícia \\
& c) Reportagem \\
& d) Entrevista \\
\hline \multirow{5}{*}{ 2. Gênero opinativo } & a) Editorial \\
& b) Comentário \\
& c) Artigo \\
& d) Resenha \\
& e) Coluna \\
& f) Crônica \\
& g) Caricatura \\
& h) Carta \\
\hline
\end{tabular}




\begin{tabular}{|c|l|}
\hline QUADRO 3 & \multicolumn{1}{|c|}{$\begin{array}{c}\text { NOVA CLASSIFICAÇÃO - } \\
\text { Marques de Melo }\end{array}$} \\
\hline \multirow{3}{*}{ 1. Gênero informativo } & $\begin{array}{l}\text { a) Nota } \\
\text { b) Notícia } \\
\text { c) Reportagem } \\
\text { d) Entrevista }\end{array}$ \\
\hline \multirow{4}{*}{ 2. Gênero opinativo } & a) Editorial \\
& b) Comentário \\
& c) Artigo \\
& d) Resenha \\
& e) Coluna \\
& f) Crônica \\
& g) Caricatura \\
& h) Carta \\
\hline \multirow{3}{*}{ 3. Gênero interpretativo } & a) Dossiê \\
& b) Perfil \\
& c) Enquete \\
& d) Cronologia \\
\hline \multirow{3}{*}{ 4. Gênero utilitário } & a) Indicador \\
& b) Cotação \\
& c) Serviço \\
\hline \multirow{5}{*}{ Gênero diversional } & a) História de interesse humano \\
& b) História colorida \\
\hline
\end{tabular}

Diante destas divisões, é válida a observação de que, em décadas anteriores, um arquivo fotográfico e uma biblioteca constituíam o setor de pesquisa de um jornal. Hoje, na era tecnológica, a investigação é facilitada e ampliada, sem a necessidade de que o repórter esteja in loco. Verifica-se, com isto, a tendência ao interpretativo em substituição à objetividade noticiosa e ao caráter competitivo entre os meios tradicionais (impresso, rádio e televisão) e o digital.

Em relação aos gêneros, a notícia continua sendo o diferencial. Em $O$ Capital da Notícia, Ciro Marcondes Filho revela que, da forma que ela se apresenta, como um fragmento da realidade, de onde é extraído somente o fato específico que a originou e com disposição múltipla no jornal (impresso), rádio, cinema e televisão, "atua no receptor participando de um jogo psíquico: ora desencadeia processos de preocupação, ora atua trazendo alívio e descontração" (1986:14).

No entanto, é sobre o caráter de mercadoria, a ser apresentado por Nilson Lage, já mencionado por Bucci, atribuído às notícias que Marcondes Filho discorre: "elas não são apenas produtos, como supõe a acepção mais ingênua, mas mercadorias" (1986:25). Em sua análise, são produzidas para um determinado mercado com incumbência à sua dupla dimensão: o uso e a troca. 
Neste pensamento sob orientação marxista uma informação pura e simples não tem essa missão mercadológica, pois, é necessário que ela seja transformada no gênero para adquirir este sentido.

Um acidente só vira notícia se nele estiver envolvido alguém, que o jornal pretenda destacar, conforme suas intenções, positiva ou negativamente. $\mathrm{O}$ jornal, então, cria a partir da matéria-prima informação, a mercadoria notícia, expondo-a à venda (por meio de manchete) de forma atraente. Sem esses artifícios a mercadoria não vende, seu valor de troca não se realiza. (MARCONDES FILHO, 1986:25)

Após, o tratamento valorativo e a inserção da ficção, em relação à linguagem, Nilson Lage (2003) aponta que as mensagens do universo jornalístico tem como referencial o "mundo de fora" ao emissor, receptor e processo de comunicação em si, o que impõe, de certa maneira, o uso da terceira pessoa da conjugação e estabelece o domínio capaz de diferenciar esta linguagem de outras.

Lage afirma que "o texto jornalístico procura conter informação conceitual, o que significa suprimir usos linguísticos pobres de valores referenciais" (2003:36) e defende que sua função é "processar a informação para o consumo imediato" (2003:35). Explana também sobre o caráter mercantil da comunicação, abordado anteriormente.

As habilidades de informar, opinar e interpretar são essenciais na produção, leitura e estruturação destes gêneros, bem como a relação entre o caráter mercadológico e os aspectos ideológicos e políticos vertentes de estudos possíveis com as linguagens comunicacionais.

Ainda mais nesta pesquisa que trata da recepção de jovens alunos dos anos finais do Ensino Fundamental, os nativos digitais - termo de Marc Prensky já abordado, que estão submersos neste universo e usufruem constantemente os recursos imagéticos, o que os torna cada vez mais o público-alvo (leiam-se consumidores).

Ao contrário da mensagem jornalística, a publicitária cria e exibe um mundo perfeito e ideal, por vezes surreal. Entre suas características está a necessidade de seduzir e convencer o receptor, sem transparecer as verdadeiras intenções, por meio de uma infinidade de recursos linguísticos, estilísticos, persuasivos e ordenativos.

Em relação aos conceitos, autores como Patrick Charaudeau (1984:1) consideram a propaganda mais abrangente que a publicidade: a primeira estaria relacionada aos conteúdos político, religioso, institucional e comercial; já a segunda limitar-se-ia aos comerciais. 
Dito de outra forma, por Nelly Carvalho (1996:162):

O paradoxo da propaganda é que, sem outro objetivo senão agir, ela atinge seus fins utilizando o que a linguagem tem de mais gratuito e gratificante: o jogo, a imaginação, a poesia. A função poética fixa a atenção na forma da mensagem, desviando-a do que é dito. A função da publicidade é o oposto: se nos fixarmos na forma, não compraremos o produto. Daí ela ser achado verbal, mas não uma poesia; um achado verbal que consiste em usar algo extraordinário para falar de coisas banais. A criação não é um ato livre; é um auxílio de vendas, em que o artista tem consciência de sua sujeição à sociedade de consumo.

Diante das perspectivas apresentadas, observamos que, se por um lado existe o destaque à consciência do indivíduo mediante apelos do discurso publicitário, por outro há obstáculos na interpretação de aspectos conotativos e denotativos, além de estratégias linguísticas acopladas às marcas, ou seja, aos símbolos divulgados na mídia. Destaca-se a crença, disseminada com o auxílio dos meios comunicacionais, segundo a qual existe, por parte da publicidade, uma capacidade de manipulação gigantesca, capaz de direcionar os indivíduos ao consumo desenfreado e inconsciente.

Nesse sentido, Nelly Carvalho reforça que o texto publicitário, qualquer que seja a imagem implícita, "é o testemunho de uma sociedade de consumo e conduz a uma representação da cultura a que pertence, permitindo estabelecer uma relação pessoal com a realidade particular" (1996:106).

Isleide Fontenelle, em $O$ nome da marca: McDonald's, fetichismo e cultura descartável, trata com profundidade a construção imagética da citada rede de fast food multinacional, tese de seu doutorado. Em capítulo específico, ressalta o jogo do "faz-deconta" entre a linguagem publicitária e a marca em si, no que chama de sociedade midiática. Para citar um exemplo, o boneco Ronald se tornou a "personalidade de marca" do McDonald’s (objeto de pesquisa), uma espécie de personificação feita por meio de associações: "se essa marca fosse uma pessoa, ela seria alegre, divertida e amigável".

A autora apresenta questionamentos sobre a manipulação da propaganda: "se não se trata do 'lugar' e, nem mesmo, de o consumidor acreditar, racionalmente, nas imagens de marca veiculadas pela propaganda, de que experiência se trata, então? Que prazer real a marca oferece ao sujeito para que lhe corresponda?” (2002:258) 
Fontenelle relata que estrategistas de marketing descrevem a necessidade de entender a mente do consumidor para que se possa prever o comportamento no ato da compra do produto. De acordo com especialistas no assunto, "ao ser escalado para participar de um grupo de pesquisa o sujeito vira um personagem, abandona sua espontaneidade, intuição, caprichos e excentricidade" (2002:258).

Eis o paradoxo:

O desejo da marca, que é, no final das contas, o do próprio capital, é criar um estado de absoluta dependência do sujeito que, do ponto de vista de 'um tipo ideal', constituiria o mesmo que acontece com a toxicomania: o fato de que existe um objeto, um objeto fabricado, suscetível de anular todo gozo outro que não aquele que ele oferece, suscetível, por outro lado, de provocar o que se chama 'esse estado de dependência' que faz com que não seja mais possível prescindir dele isso é muito exatamente o ideal [...] (FONTENELLE, 2002:259).

A autora declara, entretanto, não pertencer nem ao grupo dos apocalípticos nem ao dos integrados, e sim parte do pressuposto de que não é na imagem dos sonhos que uma marca se sustenta, mas a partir de seu nome. Esta é a forma pela qual é encaminhado o processo ideológico contemporâneo, em relação ao denominado "império das imagens", que seria formado pela própria cultura. Ao nos mostrar um mundo sem formas, provoca sentimentos de desagregação, base das teorias pós-modernas sobre o sujeito fragmentado, sobre a perda de significado; portanto, sobre a impossibilidade de representação (2002:260).

Fontenelle traz à discussão a simbiose entre publicidade e cultura e conclui, que o descartável se configura como condição necessária para a reprodução veloz do capitalismo de imagens, apoiada em estudos de Theodor Adorno e Max Horkheimer sobre "indústria cultural" e no trabalho de Frederic Jameson a respeito da estética.

Ainda, destaca que a dimensão imagética perpassa a característica visual, tornando-se uma "ilusão de forma"; daí o entendimento da chamada "forma publicidade" de Jean Baudrillard, "da transparência superficial de todas as coisas, da sua superficialidade absoluta e da qual, a publicidade profissional é apenas uma forma episódica” (1991:114).

Para Gilles Lipovetsky, a evolução da propaganda nas últimas décadas revela "uma lógica do absurdo, o jogo do sentido e do não sentido" e "um tom humorístico vazio e ligeiro nos antípodas da ironia mordaz", ou seja, uma mensagem que não quer dizer nada. Neste aspecto, sedução, publicidade e pós-modernidade, vocábulos inseridos em uma e por uma 
sociedade consumista, causam estranheza aos intelectuais "politicamente corretos", como ele ressalta

O autor afirma que essa tríade pode, sim, emitir conteúdo emancipador e critica os teóricos apocalípticos - acredita que atacam estes conceitos por atribuírem a eles a responsabilidade por de boa parte dos males do capitalismo contemporâneo.

Tenho dito que não me incomoda nem um pouco legitimar a sociedade de consumo. Sou favorável a ela. Critico, em contrapartida, o fato de a sociedade de consumo não conseguir incluir todos os indivíduos na sua esteira. O problema é a exclusão, não o consumo. Dito de outra forma, criticável não é a extensão da sociedade de consumo, mas o seu déficit (LIPOVETSKY, 2000:7).

Ele defende (2000) que o desejo não é derivado da manipulação publicitária, pois o consumidor não é enganado, mas encantado por ela. Nenhum anúncio publicitário, por mais sedutor que seja, convencerá os consumidores pós-modernos a abdicarem da liberdade de escolha que arduamente conquistaram. $\mathrm{Na}$ análise que apresenta, é a predisposição que leva alguém a ser seduzido, afinal, há um limite para a persuasão e a tirania dos modelos de conduta, principalmente entre os mais jovens na sociedade contemporânea.

\subsubsection{Na escola: dos gêneros à produção jornalística}

Os gêneros notícia, entrevista, reportagem (incluindo gráfico e tabela), editorial, debate, carta argumentativa, crônica, resenha, sinopse, cartum, charge, biografia e caricatura estão elencados no Plano de Ensino Anual de Língua Portuguesa do $8^{\circ}$ ano do Ensino Fundamental de Barueri (ver anexo A).

Nos quatros bimestres que compõem o ano letivo, os textos jornalísticos são hegemônicos. Eles são divididos de acordo com os quatro blocos de conteúdos da disciplina estabelecidos pelos Parâmetros Curriculares Nacionais (PCNs): Língua Oral; Língua Escrita: prática de leitura; Língua Escrita: produção de texto; Análise e reflexão sobre a língua. Para ilustrar, recortamos os gêneros do Plano de Ensino Anual fornecido pela Secretaria Municipal de Educação de Barueri apenas o $1^{\circ}$ bimestre (meses de março e abril) durante o qual devem ser abordados na prática pedagógica em Língua Portuguesa: notícias, entrevistas, reportagens, gráficos e tabelas. 
Em cada bloco, são orientadas habilidades para o uso específico de acordo com o texto. Ao professor, cabe discorrer sobre a justificativa da disciplina, objetivos gerais, metodologia de ensino, recursos e referencial teórico. A seguir, um recorte do $1^{\circ}$ Bimestre letivo do referido ano de ensino.

\section{LÍNGUA PORTUGUESA - $8^{\circ}$ ANO - $1^{\circ}$ BIMESTRE}

\begin{tabular}{|c|c|c|}
\hline $\begin{array}{l}\text { Bloco de } \\
\text { conteúdo }\end{array}$ & Habilidades & Conteúdos \\
\hline 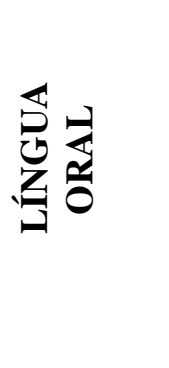 & $\begin{array}{l}\text { 1.1 Ler e comparar textos para conclusões e exposições } \\
\text { de ideias. } \\
1.2 \text { Analisar e inferir informações nos textos para troca } \\
\text { de opiniões. } \\
\text { 1.3 Identificar elementos que caracterizam e diferenciam } \\
\text { os gêneros. } \\
\text { 1.4 Tirar conclusões e fazer comentários a partir de } \\
\text { dados apresentados. }\end{array}$ & $\begin{array}{l}\text { 1. Notícias, entrevistas, } \\
\text { reportagens, gráficos e } \\
\text { tabelas. }\end{array}$ \\
\hline \multirow{4}{*}{ 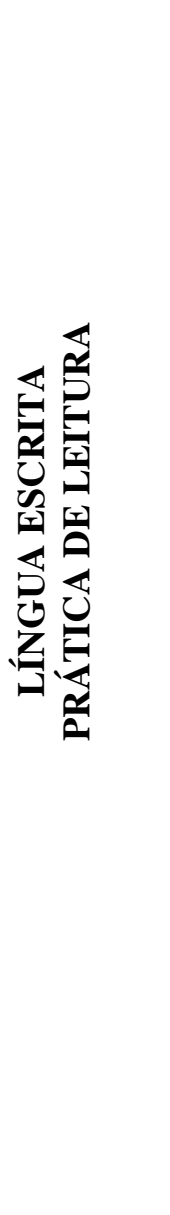 } & $\begin{array}{l}\text { 2.1 Reconhecer traços característicos do gênero e da } \\
\text { estrutura notícia. } \\
\text { 2.2 Reconhecer diferenças e semelhanças entre gêneros } \\
\text { da mesma tipologia. } \\
\text { 2.3 Identificar valores culturais e sociais em notícias de } \\
\text { jornais. } \\
\text { 2.4 Analisar e comparar diferentes notícias sobre o } \\
\text { mesmo assunto em diferentes suportes de circulação. }\end{array}$ & $\begin{array}{l}\text { 2. Notícias de diferentes } \\
\text { revistas e jornais. }\end{array}$ \\
\hline & $\begin{array}{l}\text { 3.1 Reconhecer traços característicos do gênero } \\
\text { entrevista. } \\
\begin{array}{l}3.2 \text { Estabelecer relações entre o texto e os } \\
\text { conhecimentos prévios. }\end{array}\end{array}$ & $\begin{array}{l}\text { 3. Entrevistas de diferentes } \\
\text { revistas e jornais. }\end{array}$ \\
\hline & $\begin{array}{l}\text { 4.1 Reconhecer elementos organizacionais e estruturais } \\
\text { característicos do gênero. } \\
4.2 \text { Identificar diferentes suportes de circulação de uma } \\
\text { mesma reportagem. } \\
4.3 \text { Compreender critérios de organização das } \\
\text { informações distribuídas em parágrafos. } \\
4.4 \text { Diferenciar os gêneros notícia, entrevista e } \\
\text { reportagem e suas estruturas. }\end{array}$ & 4. Reportagens. \\
\hline & $\begin{array}{l}\text { 5.1 Reconhecer informações a partir de gráficos e } \\
\text { tabelas. } \\
5.2 \text { Tirar conclusões de dados parciais a partir de dados } \\
\text { observados e analisados em pesquisas. }\end{array}$ & 5. Gráficos e tabelas. \\
\hline
\end{tabular}




\begin{tabular}{|c|c|c|}
\hline \multirow{2}{*}{ 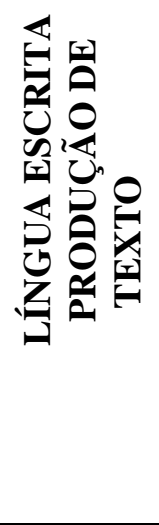 } & $\begin{array}{l}\text { 6.1 Construir tabelas e gráficos a partir de informações } \\
\text { coletadas. } \\
6.2 \text { Transformar dados em textos coerentes e coesos. }\end{array}$ & $\begin{array}{l}\text { 6. Construção de gráficos e } \\
\text { tabelas. }\end{array}$ \\
\hline & $\begin{array}{l}\text { 7.1 Produzir texto fazendo uso dos mecanismos de } \\
\text { coerência e coesão. } \\
7.2 \text { Escrever parágrafos organizados, utilizando } \\
\text { conhecimentos adquiridos de acordo com o contexto e a } \\
\text { situação de comunicação. } \\
7.3 \text { Revisar e reescrever o texto de acordo com os } \\
\text { conteúdos linguísticos estudados. }\end{array}$ & $\begin{array}{l}\text { 7. Notícias, entrevistas e } \\
\text { reportagens. }\end{array}$ \\
\hline \multirow{5}{*}{ 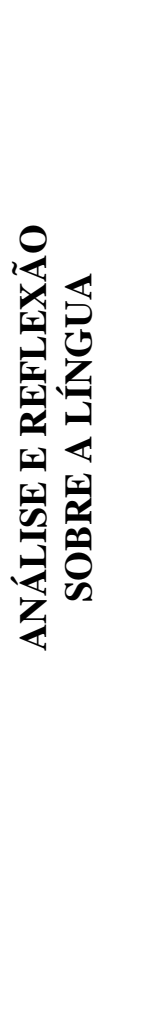 } & $\begin{array}{l}8.1 \text { Utilizar corretamente o hífen nas palavras } \\
\text { compostas. }\end{array}$ & 8. Fonética - uso do hífen. \\
\hline & $\begin{array}{l}\text { 9.1 Revisar os conceitos gerais das classes gramaticais: } \\
\text { verbo, substantivo, adjetivo, numeral, pronome, } \\
\text { preposição, interjeição e artigo. }\end{array}$ & $\begin{array}{l}\text { 9. Morfologia - revisão das } \\
\text { classes gramaticais - verbo, } \\
\text { substantivo, adjetivo, numeral, } \\
\text { pronome, preposição, } \\
\text { interjeição e artigo. }\end{array}$ \\
\hline & $\begin{array}{l}\text { 10.1 Identificar o sujeito da oração e sua relação de } \\
\text { sentido com o predicado. } \\
10.2 \text { Identificar os verbos de ligação e sua função na } \\
\text { oração. } \\
\text { 10.3 Reconhecer os tipos de predicado. } \\
\text { 10.4 Reconhecer e estabelecer relações entre o } \\
\text { predicativo do sujeito e o sujeito da oração. }\end{array}$ & $\begin{array}{l}\text { 10. Sintaxe - sujeito - conceito } \\
\text { geral e tipos de sujeito; verbo } \\
\text { de ligação; predicado - } \\
\text { conceito geral e tipos de } \\
\text { predicado; predicativo do } \\
\text { sujeito. }\end{array}$ \\
\hline & $\begin{array}{l}11.1 \text { Grafar corretamente as palavras com sons iguais ou } \\
\text { parecidos. }\end{array}$ & $\begin{array}{l}\text { 11. Ortografia - uso de U e L; } \\
\text { C, Ç e SS; E e I; Z e S; U e O; } \\
\text { X. }\end{array}$ \\
\hline & 12.1 Revisar e reescrever textos. & $\begin{array}{l}\text { 12. Revisão e reescrita de } \\
\text { textos. }\end{array}$ \\
\hline
\end{tabular}

O quadro acima estabelece os objetivos do currículo na referida disciplina em relação ao trabalho com os gêneros jornalísticos. De acordo com Maria Alice Faria (2011), autora de O jornal em sala de aula e Como usar o jornal em sala de aula, algumas habilidades importantes são adquiridas com o uso do jornal na escola, tais como: identificar, isolar, relacionar, combinar, comparar, selecionar, classificar, ordenar e deduzir.

Enquanto recurso pedagógico Faria elenca uma série de atividades para a produção jornalística, ordenadas da seguinte forma: no primeiro momento, o aluno entra em contato com o jornal, depois o conhece, visita-o e aprofunda o estudo com sua análise. A autora 
destaca ainda a importância de ações pedagógicas com este tipo de texto que considerem a tríade: texto, imagem e diagramação.

Entretanto, o discurso jornalístico, permite estratégias de persuasão e compreensão diversificadas da tradição escolar e possibilita novas leituras, alternativas de escrita e construções discursivas, como destaca Adilson Citelli (2006:41-42):

Ao movimentar o mundo das palavras, os veículos de comunicação fazem mais do que lançar mão de um mediador técnico capaz de apresentar pensamentos ou embelezar ideias. Trata-se, antes de tudo, de criar alternativas e escolhas facultadas por este ou aquele termo, esta ou aquela maneira de elaborar o enunciado, e, por decorrência, a informação, o conhecimento, em caso limite, o saber. Parte destes procedimentos poucos afeitos à ingenuidade de identificar na palavra apenas um nomeador de coisas são estratégias de persuasão e convencimento que darão suporte à elaboração, manutenção, reformulação de entendimentos e compreensões, crenças e valores, jogos de revelação e ofuscamento de ideologias, mecanismos que acentuam ou obscurecem interesses, compromissos com grupos e classes: num termo, a inocência recebe de presente um sonoro grito de adeus.

Citelli observa o texto jornalístico na escola para além da estruturação textual e interpretação da informação, considerando os recursos ideológicos, persuasivos. Com caráter normativo, em $O$ dispositivo pedagógico da mídia: modos de educar na (e pela) TV (2002), que a pesquisadora Rosa Maria Bueno Fischer, atribui aos meios comunicacionais, como a televisão, a noção de "dispositivo pedagógico da mídia”, com base no pensamento de Michel Foucault. Considera:

Um aparato discursivo (já que nele se produzem saberes, discursos) e ao mesmo tempo não discursivo (uma vez que está em jogo nesse aparato uma complexa trama de práticas, de produzir, veicular e consumir TV, rádio, revistas, jornais, numa determinada sociedade e num certo cenário social e político) a partir da qual haveria uma incitação ao discurso sobre "si mesmo". (FISCHER, 2002:155) 
Fischer centraliza sua investigação nas estratégias da TV para se firmar como um local especial de "educar", da "verdade", ao realizar a apuração dos fatos (violências, crimes), e sobre a constante atribuição do concreto a TV, ou seja, o "ensinar como fazer" acerca das tarefas cotidianas. Em Mídias, máquinas de imagens e práticas pedagógicas (2007), ressalta a urgência de incluir os materiais midiáticos e suas relações com o social e o cultural nos debates sobre didática e prática de ensino; recorre ao inglês Roger Silverstone e sua obra Por que estudar a mídia? para observar que:

[...] é impossível pensar as relações entre mídia e educação sem pensar em lutas de poder, em estratégias de controle globalizadas, em batalhas pelo controle das grandes redes de comunicação e, ao mesmo tempo, em lutas de grupos e indivíduos para terem acesso e participação quanto à informação e ao direito de voz e de expressão (FISCHER, 2007:293).

Não obstante essas profundas reflexões, no material pedagógico os "Cadernos de Apoio Pedagógicos" de Língua Portuguesa, do $8^{\circ}$ ano do Ensino Fundamental, distribuído aos alunos de Barueri, o texto jornalístico permanece reduzido às estratégias de escrita e estruturação.

Para escrever notícias ou relatar fatos você não precisa ser, necessariamente, um jornalista. Muitas vezes na escola, você é colocado em situações de escrita e levado a escrever textos jornalísticos. Os textos jornalísticos podem ser de diferentes formas e estilos de acordo com o tema tratado. Eles também podem ser informativos (notícia, reportagem e entrevista) ou opinativos (editorial, artigo, coluna e crônica) ${ }^{22}$.

Quanto à estrutura das unidades de estudo ( $8^{\circ}$ ano), notamos que, à apresentação do gênero notícia, abraço etapas de trabalho com atividades de vocabulário, interpretação de texto, estudo do texto, gramática, ortografia e produção textual de acordo com a temática exposta no próprio gênero.

\footnotetext{
${ }^{22}$ BARUERI, Prefeitura Municipal de. Material Didático do Ensino Fundamental. Cadernos de Apoio. $8^{\circ}$ ano $/ 7^{\mathrm{a}}$ série: $1^{\circ}$ semestre 2011.
} 
Durante todo o ano letivo os professores atuam com ações didáticas pedagógicas voltadas à linguagem jornalística que atendem à organização proposta no documento norteador: notícia, reportagem, reportagem com gráficos e tabelas ( $1^{\circ}$ bimestre); editorial, carta do leitor ( $2^{\circ}$ bimestre); crônica, sinopse, resenha de filmes ( $3^{\circ}$ bimestre); cartum, charge, biografia e caricatura ( $4^{\circ}$ bimestre). Os textos publicitários, pela proposta do documento, não são sugeridos no plano de ensino do $8^{\circ}$ ano do Ensino Fundamental.

2.7.2. Composição, códigos e imagens na linguagem publicitária em sala de aula

De acordo com Manuel Castells, anunciado anteriormente, os adolescentes contemporâneos estão inseridos na cultura da virtualidade real. Em um mundo movido por ícones, sons, ideias que se mesclam, que se inter-relacionam, apresentam-se as mais diversas possibilidades de uma comunicação híbrida e volátil. O que antes era "estático" se desmancha em novas formas, cores e relações linguísticas.

Neste sentido, o texto publicitário na escola possibilita o uso de uma tríade relevante para a prática pedagógica, direcionada sobretudo às jovens gerações: o trabalho com imagens, tecnologia e audiovisual. A questão da manipulação de códigos objetos, ideias, consumo, legitimam ações didáticas com estes tipos de mensagens em sala de aula.

Para Eliana Nagamini (2000), a publicidade constrói seus discursos através deste universo iconográfico que irá resgatar aspectos do individual no coletivo. Ela representa sujeitos com sonhos e desejos comuns, já que o grau de identificação pode determinar a circulação do produto no mercado consumidor.

Analisar os mecanismos de construção discursiva é importante para a compreensão dos valores e comportamentos aceitos pela sociedade e enraizados em nossa cultura. Na visão da autora (2000:77):

Estudar, na sala de aula, as estratégias linguísticas utilizadas na construção do discurso publicitário contribuirá para um melhor entendimento das potencialidades de uso da língua, nos diferentes meios de comunicação. Essa atividade pode apresentar desafios tanto para o aluno como para o professor que, ao exercer o seu papel de mediador, terá de ser também um 'leitor crítico' para elaborar a sua pesquisa e buscar novas metodologias. 
O pensamento de Nagamini encontra vozes entre autores que criticam a "resistência" dos professores para a utilização das linguagens não-verbais. Jesús Martín-Barbero e Gérman Rey, na obra Os exercícios do ver: hegemonia audiovisual e ficção televisiva, destacam que "a escola ainda prolonga, como nenhuma outra instituição, o regime do saber que o texto impresso instituiu" (2001:56). Outra crítica que Barbero e Rey apontam é a forma de utilização, atribuindo à desconfiança da escola que, na visão dos autores, parece tentar exercer um controle sobre o uso da imagem de duas formas típicas: uma subordinando-a a mera ilustração do texto escrito e outra acrescentando uma legenda, ou seja, impondo o significado de sua leitura.

No Plano de Ensino Anual de Língua Portuguesa do $9^{\circ}$ ano do Ensino Fundamental de Barueri (ver anexo $B$ ), o texto publicitário é sugerido no $2^{\circ}$ bimestre letivo, sem especificações dos tipos de texto conforme demonstrado na tabela abaixo. Quanto à leitura, os educadores possuem liberdade de escolha das ações didáticas.

\section{LÍNGUA PORTUGUESA - 9 ANO}

\begin{tabular}{|c|c|c|}
\hline $\begin{array}{l}\text { Bloco de } \\
\text { conteúdo }\end{array}$ & Habilidades & Conteúdos \\
\hline \multirow{2}{*}{ 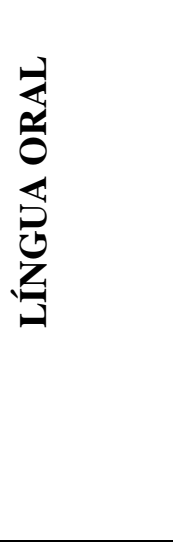 } & $\begin{array}{l}\text { 1.1 Comparar textos e expressar opiniões. } \\
1.2 \text { Expressar opinião, expor argumentos pertinentes } \\
\text { ao gênero e defender oralmente seu ponto de vista. }\end{array}$ & $\begin{array}{l}\text { 1. Carta argumentativa - } \\
\text { estrutura e elementos } \\
\text { constituintes do gênero; } \\
\text { elementos da comunicação: } \\
\text { emissor, restinatário, } \\
\text { mensagem, canal, contexto. } \\
\end{array}$ \\
\hline & $\begin{array}{l}\text { 2.1 Perceber a intenção do texto publicitário. } \\
\text { 2.2 Reconhecer a linguagem e os recursos persuasivos } \\
\text { do gênero. } \\
\text { 2.3 Realizar apresentação oral adequada à situação de } \\
\text { interlocução. }\end{array}$ & $\begin{array}{l}\text { 2. Texto publicitário }- \\
\text { elementos constituintes do } \\
\text { gênero; objetivos e recursos da } \\
\text { linguagem. }\end{array}$ \\
\hline 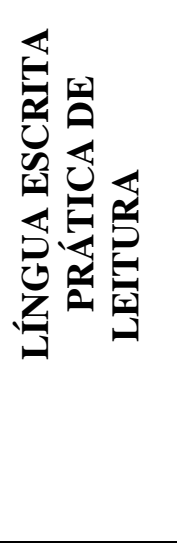 & $\begin{array}{l}\text { 3.1 Identificar as características do gênero. } \\
\text { 3.2 Identificar elementos internos específicos do } \\
\text { gênero: introdução com a tese, apresentação de dados, } \\
\text { nova tese com opinião do autor. } \\
\text { 3.3 Relacionar o texto ao seu contexto de produção e } \\
\text { suporte de circulação original. } \\
\text { 3.4 Estabelecer relações entre o texto e seus } \\
\text { conhecimentos prévios. } \\
\text { 3.5 Interpretar a posição do autor em relação ao texto. } \\
\text { 3.6 Observar e analisar as características da situação de } \\
\text { argumentação descrevendo-as. } \\
\text { 3.7 Inferir informações implícitas. }\end{array}$ & $\begin{array}{l}\text { 3. Carta argumentativa - } \\
\text { estrutura e r elementos } \\
\text { constituintes do gênero; } \\
\text { elementos da comunicação: } \\
\text { emissor, } \\
\text { mensagem, canal, contexto. }\end{array}$ \\
\hline
\end{tabular}




\begin{tabular}{|c|c|c|}
\hline & $\begin{array}{l}\text { 4.1 Relacionar o texto ao seu contexto de produção e } \\
\text { suporte de circulação original; } \\
\text { 4.2 Estabelecer relações entre o texto escrito (verbal) e } \\
\text { os recursos gráficos (visuais). } \\
\text { 4.3 Identificar a posição e intenção do autor em relação } \\
\text { ao texto. } \\
\text { 4.4 Analisar criticamente os conteúdos das mensagens } \\
\text { identificando os valores e as conotações que veiculam. }\end{array}$ & $\begin{array}{l}\text { 4. Texto publicitário }- \\
\text { elementos constituintes do } \\
\text { gênero; objetivos e recursos da } \\
\text { linguagem. }\end{array}$ \\
\hline \multirow{2}{*}{ 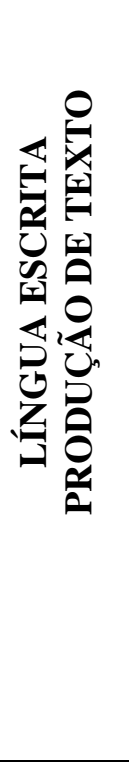 } & $\begin{array}{l}\text { 5.1 Planejar o texto a partir de informações e opiniões. } \\
\text { 5.2 Produzir texto estruturando-o de acordo com o } \\
\text { gênero. } \\
5.3 \text { Expressar sua opinião através da escrita e defender } \\
\text { seu ponto de vista com argumentos persuasivos. } \\
\text { 5.4 Reconhecer a clareza no texto e utilizar } \\
\text { articuladores sintáticos adequados ao contexto da } \\
\text { situação comunicativa. }\end{array}$ & $\begin{array}{l}\text { 5. Produção de carta } \\
\text { opinativa. }\end{array}$ \\
\hline & $\begin{array}{l}\text { 6.1 Compreender o sentido e a intencionalidade do } \\
\text { texto. } \\
6.2 \text { Produzir mensagens próprias, interagindo com o } \\
\text { meio. } \\
6.3 \text { Construir estratégias publicitárias e utilizá-las } \\
\text { como recursos persuasivos na construção do texto. } \\
6.4 \text { Produzir o texto fazendo uso da coerência e de } \\
\text { mecanismos de coesão próprios do gênero. }\end{array}$ & $\begin{array}{l}\text { 6. Produção de textos } \\
\text { publicitários. }\end{array}$ \\
\hline \multirow{5}{*}{ 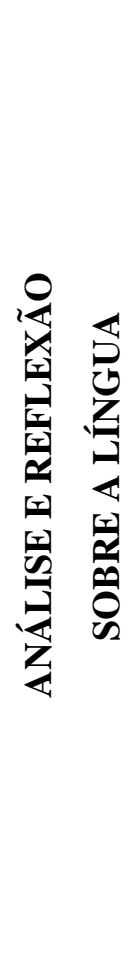 } & $\begin{array}{l}\text { 7.1 Refletir sobre o uso da linguagem, utilizar } \\
\text { adequadamente os conceitos adquiridos e estabelecer } \\
\text { diferenças entre palavras e ideias parecidas. }\end{array}$ & $\begin{array}{l}\text { 7. Semântica - uso dos porquês; } \\
\text { onde/aonde. }\end{array}$ \\
\hline & $\begin{array}{l}\text { 8.1 Examinar e utilizar corretamente as formas } \\
\text { nominais e o modo imperativo de acordo com a } \\
\text { intenção do texto. } \\
8.2 \text { Identificar as conjunções subordinadas e suas } \\
\text { funções dentro da oração. }\end{array}$ & $\begin{array}{l}\text { 8. Morfologia - verbos: tempos, } \\
\text { modos e formas nominais } \\
\text { (imperativo); conjunções. }\end{array}$ \\
\hline & $\begin{array}{l}\text { 9.1 Fazer a concordância nominal e verbal de acordo } \\
\text { com a norma culta da língua. } \\
9.2 \text { Construir conceitos referentes ao período composto } \\
\text { por subordinação. } \\
9.3 \text { Classificar as orações subordinadas estabelecendo } \\
\text { relação de sentido entre os períodos. }\end{array}$ & $\begin{array}{l}\text { 9. Sintaxe - concordância } \\
\text { nominal e concordância verbal; } \\
\text { período composto por } \\
\text { subordinação; orações } \\
\text { subordinadas substantivas. }\end{array}$ \\
\hline & 10.1 Grafar corretamente as palavras & $\begin{array}{l}\text { 10. Ortografia - uso de G e J; S, } \\
\text { SS, SC, X e XC. }\end{array}$ \\
\hline & 11.1 Revisar e reescrever textos. & $\begin{array}{l}\text { 11. Revisão e reescrita de } \\
\text { textos. }\end{array}$ \\
\hline
\end{tabular}


Na Unidade 2 do material pedagógico de apoio de Língua Portuguesa do referido ano, a apresentação do texto publicitário aos alunos ocorre da seguinte forma:

\begin{abstract}
Você, provavelmente, já passou por alguma situação em que ao observar um anúncio publicitário não entendeu exatamente a intenção da mensagem veiculada e somente quando alguém apresentou algum detalhe é que entendeu o sentido. Isso ocorre porque a compreensão de uma mensagem publicitária, seja por imagem ou texto, requer que o leitor/consumidor esteja atento e seja crítico, já que alguns textos publicitários não oferecem todos os elementos para uma compreensão imediata ${ }^{23}$.
\end{abstract}

Observamos, no enunciado proposto, a decodificação no processo imagético deste tipo de texto. Slogans, folhetos, anúncios (TV, revista, outdoor, busdoor) e logotipos são os gêneros apresentados nesta unidade de estudo.

A relação apontada entre o visual e a habilidade de interpretação corrobora a proposta do espanhol Fernando Hernández em Cultura Visual, Mudança Educativa e Projeto de Trabalho (2000). A obra de Hernández, apesar de direcionada à implantação da cultura visual em Artes nos currículos, como projeto de trabalho versa o uso da imagem para além do prazer e consumo. O autor postula que "um estudo sistemático sobre a cultura visual pode proporcionar uma compreensão crítica de seu papel e de suas funções sociais e das relações de poder às quais se vincula, além de mera apreciação ou de prazer que proporcionam" (2000:135).

Hernández reforça que esta linguagem exerce a função metafórica da "ponte", medida que permite conectar e relacionar para compreender e aprender, para transformar o universo de fora da escola (o aparelho de vídeo, os videoclipes, as capas de CD, a publicidade, a moda e o ciberespaço etc.), com a utilização de estratégias para decodificá-lo e reinterpretá-lo, no ambiente educativo.

\footnotetext{
${ }^{23}$ BARUERI, Prefeitura Municipal de. Material Didático do Ensino Fundamental. Cadernos de Apoio. $9^{\circ}$ ano $/ 8^{\mathrm{a}}$ série: $1^{\circ}$ semestre 2011.
} 


\subsection{Mídia e modelo escolar: em tempos de convergência}

As relações advindas da tríade universo escolar, mídia e cultura são estudadas pela argentina Beatriz Sarlo. A pedagoga, filósofa, estabelece um conceito de Cultura (com C maiúsculo) resultante da confluência destes três campos: 1) a popular, entendida como instrumentos culturais dos diferentes grupos sociais que compõem a sociedade; 2) a letrada; 3) a da mídia, isto é, a cultura dos meios de comunicação.

Sarlo reconhece que havia uma hierarquia tradicional atribuída a estas três dimensões, pelo pressuposto de que a cultura letrada organizava as "subculturas" (popular e midiática). Para a autora, atualmente esse modelo perdeu a legitimidade e as outras duas acabaram não conseguiram se impor de forma hegemônica; ouve uma quebra das dicotomias e ambas estão em constante retroalimentação.

A argentina aponta a desigualdade social como um fator importante na dificuldade de acesso àquele tipo letrado e aos bens culturais que ela legitima, em sobreposição aos bens produzidos pelas classes populares, que são considerados "desqualificados". Em sua opinião, a livre manifestação dos diferentes níveis de uma sociedade exige "a garantia de um acesso democrático aos armazéns onde estão guardadas as ferramentas: forte escolaridade e amplas possibilidades de opção entre diferentes ofertas audiovisuais que concorram com a repetida oferta dos meios capitalistas, tão iguais a si próprios quanto às mercadorias que produzem" (SARLO, 1997:22).

Neste ínterim, expõe que o acesso à elas é função da escola: espera-se dessa instituição um espaço de diálogo permanente e não hierarquizado, o que significa não desconsiderar outras formas culturais no currículo.

A postura dialógica, de espaços livres e não hierarquizados, propostos por Beatriz Sarlo, enfrenta os desafios da convivência com um paradigma institucional que é reflexo do Iluminismo, marca da Idade Moderna, segundo o qual os saberes estão alicerçados na racionalidade científica, na orientação curricular organizada em etapas e nos conteúdos divididos em matérias escolares de forma progressiva.

Essa fragmentação do saber em disciplinas é alvo da crítica que Edgar Morin faz em defesa da interligação de todos os conhecimentos, propondo o que chamou de reforma do pensamento. No aspecto educativo, Morin mantém a ideia de sua teoria da complexidade ao olhar a sala de aula como um sistema complexo, um espaço heterogêneo, no qual a reforma do pensamento é possível. Na visão do autor, a instituição escolar precisa fazer sentido para o 
estudante. No tocante às ações pedagógicas dos professores junto aos adolescentes, objetos de nosso estudo, em sua análise sobre o chamado "ensino secundário" francês (correspondente ao nosso Ensino Fundamental II), ele defende que os docentes "têm por dever educar-se sobre o mundo e a cultura dos adolescentes" (MORIN, 2002:79).

Assim como Morin, pensamos que o conhecimento precisa estar interligado e que, o estudo no contexto escolar das linguagens da comunicação, é necessário não só para a compreensão dos produtos multiformes de industrialização e supercomercialização, mas também quanto às aspirações e obsessões próprias ao "espírito da época", que são traduzidas e atraídas pela temática.

Morin explana sobre a chamada "ecologização" das disciplinas - leva em consideração o contexto nos aspectos cultural e social ao analisar "em que meio elas nascem, levantam problemas, ficam esclerosadas e transformam-se" (2002:115). Acrescenta (2002:115): "não se pode demolir o que as disciplinas criaram; não se pode romper todo o fechamento: há o problema da disciplina, o problema da ciência, bem como o problema da vida; é preciso ao mesmo tempo que a disciplina seja aberta e fechada".

$\mathrm{Na}$ linha do pensador francês, defendemos também a necessidade de conhecer as particularidades dos sujeitos na construção de nossa pesquisa, o que requisitou observações sobre as necessidades dos professores em suas práticas pedagógicas, sem desconsiderarmos os alunos que convivem "extramuro" escolar com a comunicação e, portanto, buscam outros recursos e novas possibilidades de interação com as linguagens midiáticas e tecnologias.

Para explicar o conceito de "metadisciplina", o autor recorre ao imperativo de Blaise Pascal: "uma vez que todas as coisas são causadas e causadoras, ajudadas e ajudantes, mediatas e imediatas, e todas estão presas por um elo natural e imperceptível, que liga as mais distantes e as mais diferentes, considero impossível conhecer as partes sem conhecer o todo, tanto quanto conhecer o todo sem conhecer, particularmente, as partes" (MORIN, 2002:116).

Em outras palavras, não se pode negar que as transformações são captadas, reforçadas e geradas pelos meios comunicacionais. Tampouco é possível negar a existência da intencionalidade e acreditar que os significados produzidos são neutros. Entretanto, é preciso ir além da visão apocalíptica, como bem lembra Mauro Wilton de Sousa (1997:51):

se de um lado não se inocenta a emissão, nem tampouco os compromissos ideológicos e mercadológicos presentes em sua ação, busca-se um outro olhar, um outro ângulo do mesmo processo; busca-se o receptor em suas circunstâncias, sob o olhar das práticas sociais onde se insere. 
Há tempos busca-se um consenso, através de diversos estudos e paradigmas, acerca das influências da mídia nas relações sociais. Com a ideia de identidades fluidas e moldadas, não é mais possível deixar as experiências dos indivíduos com o mundo da comunicação de fora das instâncias de educação formal.

As linguagens da mídia inseridas no fazer cotidiano dos adolescentes contemporâneos concorrem, no ambiente formal de aprendizagem, com metodologias, recursos humanos e materiais e infraestruturas ofertados pelos sistemas. A ação didática docente, o contexto, o perfil dos estudantes e os aparatos tecnológicos são bombardeados pela proliferação de outra cultura: a chamada convergente.

O foco atualmente esteia-se na reação dos professores e alunos frente aos processos de transformação dos media e à interferência que estes provocam no ensino e na aprendizagem.

Henry Jenkins, em A cultura da convergência, a define como "o fluxo de conteúdos por meio de múltiplos suportes midiáticos, à cooperação entre inúmeros mercados e ao comportamento migratório dos públicos dos meios de comunicação" (2009:29).

Sob a perspectiva de Jenkins, é possível a compreensão de que os velhos meios comunicacionais não estão sendo substituídos pelos novos, como se pensava; o que ocorre, em sua visão, é a mudança nas funções com a introdução de tecnologias.

$\mathrm{O}$ autor explica que a convergência não deve ser compreendida apenas como um processo tecnológico que une várias funções dentro dos mesmos aparelhos já que representa uma transformação cultural, à medida que consumidores são incentivados a procurar novas informações e fazer conexões em meio a conteúdos midiáticos dispersos (2009:30).

Ao pensarmos na sala de aula como um local propício para a manifestação dessas transformações, depreendemos que o professor tem a função de orientador na medida em que os conteúdos dos meios tornam-se "invasores" desse universo - assim, a questão do acesso passa a não ser a única preocupação, como anteriormente. Neste momento histórico, a relação em torno do consumo com esses meios, ou seja, o impacto que eles provocam no comportamento da juventude, resulta na lacuna entre os nativos e os imigrantes digitais, como já explicitado anteriormente com base na teoria de Marc Prensky. Por isto, a defesa da independência, cada vez maior, do estudante perante o educador se prolifera levantando reflexões acerca de metodologias em sala. 


\subsection{A prática pedagógica emancipadora}

Em tempos de discussão sobre a abordagem mais adequada na escola para contemplar as necessidades dos indivíduos contemporâneos, os argumentos recaem sobre as ações didáticas com vistas à autonomia. Na perspectiva educacional, existem tendências que postulam a construção de uma pedagogia que atenda ao perfil desse "novo aluno" e possibilite o reconhecimento dos múltiplos discursos sociais existentes e as formas manifestas em que são legitimados.

Vários pesquisadores e especialistas em educação afirmam que o entendimento do "sujeito da educação", como postulado pela chamada "pedagogia crítica", está em crise. A premissa básica dessa corrente de pensamento, que é "formar a consciência crítica" do discente para que seja capaz de transformar e unificar a sociedade na qual está inserido, para muitos teóricos e pedagogos parece quase impossível no modelo social de hoje, transformando-se em utopia.

Sendo assim, alguns questionamentos são pertinentes: o vislumbrar de um aluno crítico, autônomo ou emancipado não é mais possível? Ou é o entendimento de "autonomia do sujeito" que não é mais o mesmo? Então, para que tipo de sociedade se está educando? A partir dessas indagações, clarifica-se que o pressuposto de sujeito tal como proposto pelas teorias pedagógicas é questionável.

Acreditamos que o grande desafio do modelo escolar "iluminista" ainda é reconhecer, em sua constituição, as necessidades da atual forma de organização do conhecimento e, consequentemente, admitir que o professor na contemporaneidade é mais um dos mediadores desse processo, o que demandaria o repensar de todo o processo educativo. À escola formal de aprendizagem fica o papel de compreensão e ressignificação desses fenômenos provocados também pela inserção dos meios de comunicação e novas tecnologias no contexto atual, os quais alteraram consideravelmente a produção de sentidos.

Para o professor Moacir Gadotti, um dos diretores do Instituto Paulo Freire, há consenso quando se afirma que a profissão docente deve abandonar a concepção predominante no século XIX de mera transmissão do saber escolar. Em sua visão, "o professor não pode ser um mero executor do currículo oficial e a educação já não é mais propriedade da escola, mas de toda a comunidade. O professor, a professora precisam assumir uma postura mais relacional, dialógica, cultural, contextual e comunitária" (2003:26). 
Segundo o autor, a mudança de mentalidade do profissional da educação quanto aos sistemas de ensino é o maior desafio da profissão. Gadotti acrescenta que a noção de qualidade precisa de profundas mudanças: "a competência profisssional deve ser medida muito mais pela capacidade do docente estabelecer relações com seus alunos e pares, pelo exercício da liderança profissional e pela atuação comunitária, do que na sua capacidade de 'passar conteúdo'.” (2003:26)

Nessa perspectiva, uma nova cultura profissional implica uma redefinição dos sistemas de ensino e das instituições escolares, mas essa transformação não ocorre em função do ou pelo sistema - "deve partir do próprio professor e de uma nova concepção do seu papel" (GADOTTI, 2003:26).

O pedagogo apresenta duas concepções opostas da profissão: a neoliberal e a emancipadora. A primeira entende o professor como um profissional lecionador, avaliado individualmente; a segunda considera o docente como um organizador da aprendizagem (visão social). Sob o olhar emancipador, o compromisso é com a emancipação de pessoas, não é uma profissão técnica, e, portanto, sendo assim, a competência deste profissional não é medida pela capacidade de ensinar ou "lecionar", mas pela abertura de possibilidades para uma aprendizagem e convivência melhor entre os seres humanos.

O autor ressalta que o universo educacional adotou uma espécie de "modismo" quanto à aquisição de "novas competências" (2003:26), disseminadas em certa medida no Brasil pelo francês Philippe Perrenoud, para quem essa concepção está relacionada a uma visão sistêmica.

Perrenoud aponta a necessidade do desenvolvimento de práticas pedagógicas com focos reflexivos, para que o educador possa estimular o desenvolvimento de competências (ler, escrever, interpretar, calcular, comparar, inferir etc.) em seus alunos. Gadotti critica o enfoque por "competências" por lembrar "um pouco o debate da década de 80 entre competência técnica e compromisso político" (2003:40) e recorre a Paulo Freire, que tratava dos "saberes necessários à prática educativa". Na concepção freiriana, o bom professor é o que consegue, enquanto fala, trazer o educando até a intimidade do movimento de seu pensamento. Sua aula é, assim, um desafio e não uma "canção de ninar", seus alunos cansam, mas não dormem. "Cansam porque acompanham as idas e vindas de seu pensamento, surpreendem suas pausas, suas dúvidas, suas incertezas.” (FREIRE, 1996:25)

A metáfora da "canção de ninar" utilizada por Freire para demonstrar a falta de sentido para o discente, tanto do conteúdo como da metodologia utilizados pelo docente, é a grande problemática dessa relação. Este problema nos remete a outra metáfora, a da "escrivaninha", 
proposta por Walter Benjamin em Infância berlinense por volta de 1900. Neste livro, Benjamin apresenta um quadro em que a formação da criança ocorre essencialmente fora do âmbito escolar. Trata-se do "tableau", no qual "a escrivaninha" (Das Pult) que dá título à obra, localizada no apartamento do menino, torna-se uma paródia da carteira escolar e uma espécie de cúmplice da criança na luta por uma aprendizagem de vida:

Assim, aquela escrivaninha guardava, sem dúvida, certa semelhança ao banco escolar, mas sua vantagem era que nela eu ficava protegido e dispunha de espaço para esconder coisas de que ele não deveria saber. A escrivaninha e eu éramos solidários frente a ele. (BOLLE apud BENJAMIN, 1987:120)

A criança enxerga no que seria um simples mobiliário proteção e a possibilidade de uma espécie de aprendizagem diferente - o que, para autores como Willi Bolle, corresponde à "aprendizagem paralela", sobre a qual questiona: em que consiste a diferença e o que se aprende nessa escola paralela? O próprio autor explica que o diferencial é que a escrivaninha é um espaço "lúdico", que vai ao encontro do modo de ser da criança, ao passo que na escola o espírito lúdico foi substituído pelo “dever”. Afirma (1997:10): “a criança protagonista se vale da astúcia da mimese para desarmar o poder da instituição de ensino. Representando o espírito 'lúdico', a escrivaninha, como simulacro da carteira escolar, consegue desmontar o austero 'dever' desta”.

Um local que permite olhar com distanciamento crítico, assim é a escrivaninha - uma espécie de confessionário - com a leveza e o caráter lúdico que o banco escolar não permite. Walter Benjamin questiona o legado e o valor da cultura livresca em um mundo dominado pela mídia e a reprodutibilidade técnica, mas afirma que eles se encontram registrados na criança, que passa a rever seus velhos cadernos escolares (BOLLE, 1997:10).

Cadernos escolares, livros didáticos e apostilas são materiais ofertados como "apoio" ao trabalho pedagógico do educador, mas que se tornam, pela prescrição de uso do próprio sistema de ensino, uma espécie de "obrigação".

Acreditamos na busca de sentido na relação ensino e aprendizagem, ou seja, que este processo não é neutro. Retomando Moacir Gadotti, o novo profissional da educação deve se perguntar: por que aprender, para quê, contra quê, contra quem, e refletir sobre a sua tomada de posição, sobre a falta de propósito quanto ao que está ensinando e, consequentemente, sobre a falta de sentindo que está proporcionando ao aluno. Essa percepção de um professor 
"construtor de sentidos" permite o reconhecimento de seu papel de mediador do conhecimento, na medida em que o aluno é o sujeito de sua própria formação.

Neste momento, buscamos o entendimento da concepção do alemão Theodor Adorno, já citado em outro tópico, agora tratando da noção de emancipação. Adorno, Max Horkheimer, Erich Fromm, Walter Benjamin, Herbert Marcuse, entre outros, a partir da análise da economia do mercado, formaram a chamada Escola de Frankfurt, corrente da Teoria Crítica em Comunicação

O conceito de indústria cultural elaborado por Adorno e Horkheimer, tratado neste trabalho em mediações do processo comunicacional, é um marco para a análise dos meios. Na visão desses autores, os meios de comunicação, ao invés de aproximar as pessoas, acabam por afastá-las, ampliando cada vez mais as "barreiras".

$\mathrm{Na}$ perspectiva educacional, Adorno defende a autonomia do educando. Apesar do fator temporal, aproxima-se das ideias dos educadores brasileiros Moacir Gadotti e Paulo Freire.

A concepção adorniana preconiza, sobretudo, o processo emancipatório por meio de uma formação qualificada e crítica. Influenciado pelo contexto histórico-político que a Alemanha havia atravessado em sua época, ele aborda com veemência uma educação para liberdade e seu pensamento é refletido na afirmativa "a exigência de que Auschwitz não se repita é a primeira de todas para a educação" (1995:119).

No atual contexto social, a questão educacional é tema de plataformas políticas e ideológicas e questionada pela própria classe profissional que a representa. Entretanto, esta é uma indagação que há décadas acompanha os estudiosos, o próprio Adorno já fazia no debate nomeado de "Educação para quê?" na Rádio Hessenem, na década de 60, e explica seu questionamento afirmando:

a intenção não era discutir para que fins a educação ainda seria necessária, mas sim: para onde a educação deve conduzir? A intenção era tomar a questão do objetivo educacional em um objetivo fundamental, ou seja, que uma tal discussão geral acerca do objetivo da educação tivesse preponderância frente à discussão dos diversos campos e veículos da educação. (ADORNO, 1995:139)

É notável que Adorno explicite em seu questionamento que esse "para quê", no quesito Educação, como ele mesmo salienta, não é mais compreensível por si mesmo. Em 
outras palavras, esse ato de questionar em si já contém certas inseguranças e requisita reflexões complexas. Concordamos com a opinião adorniana de que, uma vez perdido esse questionamento, não basta apenas a "boa vontade" para restituí-lo.

Ainda nessa temática, o francês Jacques Rancière, em sua obra $O$ mestre ignorante: cinco lições sobre a emancipação intelectual, aborda a metodologia de ensino desenvolvido pelo pedagogo Joseph Jacotot e sua "Educação Universal". Ele difunde a noção de que todos os homens possuem igual inteligência, ou seja, não existe um indivíduo com capacidades maiores que outros, é a desigualdade que acaba favorecendo uns em detrimentos de outros.

Em sua visão, as instituições escolares não conseguem adotar o método emancipador porque estão firmadas em valores, normas e intenções ao "formatar" esse homem e, assim, ignoram o aprendiz em seu contexto de vida e saberes adquiridos em outros ambientes. Retrata uma "sociedade pedagogizada" na medida em que ela atribui à escola o poder fantasmático de realizar a igualdade social ou, ao menos, reduzir a "fratura social". É possível estabelecermos pontos de convergência entre Rancière e o brasileiro Paulo Freire - quanto à desigualdade, o francês (2002:12) afirma que:

A lógica da escola Republicana de condição da igualdade pela distribuição do universal, do saber, faz-se sempre, ela própria, prisioneira do paradigma pedagógico que reconstitui indefinidamente a desigualdade que pretende suprimir. A pedagogia tradicional da transmissão neutra do saber, tanto quanto as pedagogias modernistas do saber adaptado do estado da sociedade mantêm-se do mesmo lado (...) as duas tomam a igualdade como objetivo, isto é, tomam a desigualdade como ponto de partida.

Para Freire, a educação não deve disseminar o predomínio de uns sobre os outros, isto é, a desumanização. Deve, sim, estar a serviço de um processo libertador e gerador de uma relação dialógica entre os homens. Neste sentido, dizer a palavra é transformação do mundo, direito de todos, e não privilégio de alguns:

[...] o diálogo é este encontro dos homens, mediatizados pelo mundo, para pronunciá-lo, não se esgotando, portanto, na relação eu-tu. [...] Por isto, o diálogo é uma exigência existencial. $\mathrm{E}$, se ele é o encontro em que se solidarizam o refletir e o agir de seus sujeitos endereçados ao mundo a ser transformado e humanizado, não pode reduzir-se a um ato de depositar 
ideias de um sujeito no outro, nem tampouco tornar-se simples troca de ideias a serem consumidas pelos permutantes [...]. (FREIRE, 1987:78-79)

Tal como postulam Rancière e Freire, o português Boaventura Souza Santos, em $A$ gramática do tempo: para uma nova cultura política do tempo (2006), enfatiza que o atual sistema político dissemina o desigual e a exclusão como consequência de uma espécie de hierarquização sistêmica, ou seja, a desigualdade é fundamentada porque hierarquiza os indivíduos. A hierarquização, sobretudo de conteúdos na escola, é tema de importantes questionamentos, por isso a busca por práticas pedagógicas que exercitem o trabalho em torno do todo e não das particularidades, como proposto por Morin, e por ações que se guiem pela interface entre Comunicação e Educação.

\subsection{Comunicação e Educação: da interface à educomunicação no contexto escolar}

Nosso estudo sobre linguagens jornalística e publicitária nos anos finais do Ensino Fundamental, especificamente na disciplina de Língua Portuguesa, modalidade pública formal, ratifica a importância desta linha de pesquisa que investiga a interligação entre as áreas da Comunicação e Educação. Neste documento, estão incluídas também as ações do professor por meio do uso didático do jornalismo e da publicidade no atendimento aos jovens dos referidos anos.

A escola, representada pela sala de aula, e os meios comunicacionais vivem um embate permanente pela hegemonia na formação dos valores destes indivíduos. Alimenta, assim, uma espécie de corrida pela preferência e o destaque na configuração dos sentidos sociais. Como explicita Maria Aparecida Baccega (2011:33), é a disputa entre as chamadas agências de socialização - mídia versus escola e família:

Com o objetivo de revestir de significados os signos em circulação: ou seja, cada agência considera-se, ela própria, a única capaz e correta nesse processo de atribuição de sentidos. E há permanentemente a tentativa impossível, ainda bem - de tornar o signo monossêmico, ou seja, de pretender que o sentido atribuído à palavra por uma das agências, por exemplo, é o único e será interpretado apenas daquele modo por todos. 
Para a autora (2011), o êxito no complexo campo comunicação/educação deriva da superação de dez desafios; destacamos três: o reconhecimento dos meios como outro lugar do saber, atuando com a instituição escolar e outras, com vistas a socializar; o cuidado para não reduzir a intersecção das áreas a fragmentos na discussão sobre a utilização dos aparatos tecnológicos no âmbito educativo; a consideração sobre como os sujeitos interpretam (em todos os âmbitos) as práticas midiáticas.

Estes itens estão diretamente relacionados ao que já foi discutido, nesta pesquisa: o fato de o contexto contemporâneo gerar novos modos de ser, estar e interpretar o mundo, movimento que culmina em um conjunto de preocupações diretamente relacionadas a esta interface. $\mathrm{O}$ alvo é uma atitude, também pedagógica, que vislumbre a autonomia do indivíduo.

Ao tratarmos, no ambiente educacional, da presença e diálogo com as mensagens manifestas dos dispositivos da mídia, referimo-nos também às relações entre docente, discente e comunidade, além da análise, construção e produção dos formatos comunicacionais pelos envolvidos no processo.

Após ultrapassar os pontos conflituosos, a comunicação/educação estará apta a proporcionar aos alunos "uma produção que valorize aspectos da cultura em que se vive, que abra discussões sobre a dinâmica da sociedade, numa nova linguagem audiovisual, num novo mundo" (BACCEGA, 2011:41).

Reforçando a proposta de Baccega, Adilson Citelli destaca várias maneiras de trabalhar os vínculos da referida interface, ao tratar do plano epistemológico, “com vistas a indagar acerca de possível novo campo reflexivo e interventivo resultante dos encontros, desencontros, tensões, entre os processos comunicacionais e educação" (2010b:59).

Relativos à junção das duas áreas, Citelli arrola alguns obstáculos, já que, para o autor, não basta que os meios estejam na sala de aula, deve-se atentar aos seguintes aspectos: ajuste de projeto, sujeito na história, políticas nas áreas, lugar das tecnologias, dimensões discursivas e formação docente.

Trata-se de indagar de modo mais decisivo acerca de um sistema que, ao ser legitimado pela escola, nela se legitimará. Logo a constatação rasa de que a televisão, o rádio, a internet necessitam fazer parte das paisagens de sala de aula, afora, ser óbvia, até mesmo porque tais dispositivos já estão completamente integrados à vida dos discentes e docentes, traz consigo a ingenuidade dos crentes que confiam a salvação da alma ao pastor espertalhão. (CITELLI, 2010b:78) 
Para o autor, a simples constatação da necessidade de uso e inserção dos veículos comunicacionais no ambiente de aprendizagem não funciona porque é uma constatação óbvia, de acordo com seu ponto de vista questionamentos do tipo o que são, o que fazem, como são estruturados são fundamentais para o trabalhos em sala.

Na visão de Citelli, quanto às tecnologias no contexto educativo, o problema não é estreitar a proximidade entre as dinâmicas comunicativo-tecnológicas, mas realizar esta ligação sob um enfoque não instrumental, observação feita, anteriormente, por Raymond Williams acerca dos perigos do determinismo tecnológico. Com isto:

O lugar das tecnologias na escola - e mesmo para o chamado ensino a distância - deve ser aquele voltado para o interesse de uma educação anteriormente definida como emancipadora, capaz de facultar autonomia de pesquisa, e, sobretudo, reconhecimento do sujeito no mundo. (CITELLI, 2010b:80)

Concordamos novamente com Citelli quando considera a linguagem como elemento fundamental na composição dos processos comunicativos. Dos discursos verbais aos não verbais, perpassando a interconectividade e a hipertextualidade, existe, sim, a possibilidade da construção de valores, e este caráter, chamado pelo autor de multidimensional, pode ser encontrado no telefone celular, computador, internet ou na convergência deles.

Ainda segundo ele (2010), as telas do cinema ou televisão, a página do jornal, o programa de rádio, o visor do celular, constituem mecanismos discursivos e estratégias linguajeiras que necessitam de reconhecimento sistemático dos processos de ensinoaprendizagem que ocorrem nos espaços educativos formais.

$\mathrm{O}$ autor esclarece que os textos colocados em circulação pelos meios comunicacionais possuem uma série de intencionalidades, entre elas: informação, sedução, persuasão e convencimento.

Ao abordar a Comunicação e Educação sob a perspectiva digital, sobre as novas plataformas midiáticas e a universalização dos padrões mercadológicos da indústria cultural, Belarmino César Guimarães da Costa ressalta (2010:91):

A ação mimética, que compreende certa naturalização da técnica, é reforçada pela forma como os meios de comunicação utilizam os recursos da repetição e de engajamento dos produtos culturais, do design, da moda, da informação 
jornalística, dos modelos exibidos pela publicidade, enfim, a uma condição que ultrapassa os limites do consumo: e atua na esfera da administração das pulsões e do empobrecimento da linguagem.

Costa destaca que as novas gerações, já adaptadas aos ícones e códigos da internet, possuem potencial imensurável em relação à reconfiguração da realidade por meio da computação gráfica. Por isto, quanto à tecnologia, alerta (2010:93):

não desvelar o caráter formativo presente na tecnologia, que atua no controle e na adaptação dos sentidos, e muitas vezes na condição de isolamento do indivíduo, mesmo que conectado em redes sociais e em processos de comunicação descentrados, significa observar os fenômenos midiáticos de forma parcial, quando o que é considerado passa pelo imediatamente percebido, sem que sejam significadas as conexões de causalidade e de totalidade da relação entre a tecnologia, as necessidades humanas e a formação das habilidades.

A respeito dos suportes digitais, o autor enfatiza que, o uso "não subleva, em si, a capacidade narrativa e de expressão, em que, paralelamente, haja formação do sujeito dependente de outros fatores para se autodeterminar, como a capacidade de, no processo educativo, superar a sua adaptação ao mundo" (2010:101).

De Baccega a Citelli e Costa, o que fica nítido é o caráter formativo que não deve estar dissociado da Comunicação e Educação e/ou da utilização das novas tecnologias nestes processos. Nesta conjuntura, um termo ganha cada vez mais espaço: a educomunicação, uma nova área que trabalha na interface e, considera que, desde a produção, circulação e recepção da informação e conhecimento, a comunicação possui função central.

Entendemos que nossa pesquisa, apesar de se situar na interligação entre as áreas, compreende também ações educomunicativas, sob a perspectiva do conceito proposto pelo Núcleo de Comunicação e Educação da Escola de Comunicações e Artes da Universidade de São Paulo (NCE/ECA/USP) e pelo coordenador do NCE, Ismar de Oliveira Soares.

Para Soares, a educomunicação é um campo de ação emergente na interface entre as áreas de Comunicação e Educação. Neste sentido, aponta que o eixo das relações comunicacionais entre pessoas e grupos humanos se converte no habitat natural da nova área: 
Sua função é de qualificar tais relações a partir do grau de interação que for capaz de produzir. Conceitos como democracia, dialogicidade, expressão comunicativa, gestão compartilhada dos recursos de informação fazem parte do vocabulário. Está presente onde práticas de comunicação se manifestam com consequência para a vida em sociedade: na família, na escola, na empresa, na própria mídia. (SOARES, 2011:18)

O coordenador do NCE defende não apenas a aproximação, mas, sobretudo, a contextualização das interfaces em processos politicamente, marcados pela busca da reforma da sociedade e pela força da expansão dos sujeitos sociais.

A construção do perfil de um novo profissional, o educomunicador, é, em sua visão, cada vez mais necessária. Desde 2011 a Universidade de São Paulo oferece Licenciatura em Educomunicação, com vistas a esta formação. As práticas estão inseridas no que Soares chama de áreas de intervenção ${ }^{24}$, que totalizam seis: 1. Educação para a comunicação; 2. Expressão comunicativa através das artes; 3. Mediação tecnológica dos espaços educativos; 4. Pedagogia da comunicação; 5. Gestão da comunicação; 6. Reflexão epistemológica (SOARES, 2011:47).

O coordenador lembra que a proposta visa a cumprir o que solicitam os Parâmetros Curriculares Nacionais (PCNs) quanto à observação de como os meios agem na sociedade, além de buscar formas de colaborar com os alunos para que estes convivam com estes aparatos midiáticos de forma positiva. Entre os objetivos do campo, estão: o despertar do espírito crítico dos usuários dos meios e, na prática educativa, o uso adequado dos recursos comunicativos e tecnológicos.

Os temas transversais também são focos, pois ressaltam o conhecimento no todo e não em fragmentos. As tecnologias possuem papel importante no processo e não são entendidas apenas como "ferramentas" de auxílio ao docente; ao contrário, devem ser utilizadas para a melhoria educacional de todos os participantes da instância escolar e inclusive de seu entorno, como já exposto anteriormente.

A área da Pedagogia da comunicação é a que aborda a educação formal (o ensino escolar), pensando-a como um todo. Mantém-se atenta ao cotidiano da didática e prevê a multiplicação da ação dos agentes educativos (o professor e o aluno trabalhando juntos), optando, quando conveniente, pela ação através de projetos.

\footnotetext{
${ }^{24}$ O termo "intervenção" significa novo. Nesta linha, de acordo com Soares, pode ser incluído todo o esforço dos gestores e dos docentes no sentido de implementar projetos comunicativos com especificidades próprias, que emprestem razões para o aluno gostar da formação recebida, criando nele o desejo de vê-la difundida e multiplicada.
} 
O ensino por meio de projetos de trabalho é a proposta do espanhol Fernando Hernández, já citado em nossa referência teórica quanto ao uso da cultura visual na escola. Hernández preconiza um ensino no qual a escola é geradora de cultura e não só de aprendizagem de conteúdos. O espanhol defende a organização do currículo escolar não por disciplinas acadêmicas, mas por temas e problemas com os quais os estudantes se sintam envolvidos e aprendam a pesquisar.

Para o autor, "é necessário propor inicialmente uma problemática para depois selecioná-la, ordená-la e torná-la pública” (1998:19). É nesse sentido que as ações do campo proposto por Ismar Soares se aproximam da proposta de Hernández (exposta abaixo) quanto à pedagogia de projetos.

\section{Quadro de acordo com a proposta de Hernández para a Pedagogia de Projeto}

\begin{tabular}{|c|c|}
\hline Centralização nas matérias & Centralização nos projetos \\
\hline Conceitos disciplinares & Temas ou problemas \\
\hline Objetivos e metas curriculares & Perguntas e pesquisas \\
\hline Conhecimento canônico & Conhecimento construído \\
\hline $\begin{array}{l}\text { Unidades centradas em } \\
\text { conceitos disciplinares }\end{array}$ & $\begin{array}{l}\text { Unidades centradas em } \\
\text { temas ou problemas }\end{array}$ \\
\hline Lições & Projetos \\
\hline Estudo individual & Grupos pequenos que trabalham por projetos \\
\hline Livros-textos & Diversas fontes \\
\hline Centrado na escola & Centrado no mundo real e na comunidade \\
\hline O conhecimento tem sentido por si mesmo & O conhecimento em função da pesquisa \\
\hline Avaliação mediante provas & Avaliação contínua e autoavaliação \\
\hline O professor como especialista & O professor como facilitador \\
\hline
\end{tabular}

A pedagogia de Hernández reforça a concepção do conhecimento construído, do trabalho com projetos em pequenos grupos, de respostas a partir dos questionamentos e da centralização de ações educativas na realidade do aprendiz, considerando também o entorno do espaço escolar com vistas a uma transformação social. 
É neste ponto, da mobilização societária, que se encontra com a proposta de Soares: "estamos falando da pedagogia de projetos, que permite que mesmo ambientes rígidos e fechados possam ser beneficiados pela brisa educomunicativa”. No entanto, o pesquisador brasileiro faz uma ressalva; segundo ele, para que a efetivação desse modelo na escola seja possível, é importante que "docentes e agentes culturais eficientes e bem treinados se disponham a mobilizar colegas e estudantes em torno de determinadas zonas de interesse" (SOARES, 2011:49).

O aspecto democrático do paradigma proposto por Soares é a possibilidade de escolha da área de intervenção de acordo com as necessidades predominantes, os objetivos, espaços e sujeitos considerados na adoção das ações e suas produções.

\footnotetext{
Quanto mais áreas de intervenção estiverem sendo cobertas simultaneamente - pelos projetos em desenvolvimento numa escola, mais pessoas - professores, alunos e membros da comunidade - estarão envolvidas no processo, permitindo que a educomunicação se torne visível, notada especialmente por seus efeitos benéficos. (SOARES, 2011:50)
}

Entretanto, para a inserção de ações emancipadoras no espaço formal de aprendizagem, sobretudo da esfera pública, faz-se necessária a compreensão do funcionamento de determinados "ordenamentos" no sistema educacional, que facilitam ou dificultam, por vezes até impedem, a implantação, por parte dos professores, desse tipo de prática. Sendo assim, estes procedimentos de controle contribuem para a elaboração de um caminho que sacraliza a instituição e o seu discurso, uma espécie de proteção de "perturbações extramuros".

As atitudes pedagógicas neste espaço refletem, na maioria das vezes, os conflitos ideológicos, políticos, metodológicos, discursivos, sociais, resultantes das relações de poder estabelecidas pelos sistemas educativos, item que aprofundaremos no próximo tópico.

\subsection{A ordem discursiva: hierarquia, coerção e exclusão}

Os confrontos em sala de aula entre professor e aluno são iniciados, principalmente, por mecanismos (currículo, método, conteúdo disciplinar, normas, leis) que atuam (in) 
diretamente no fazer didático. Ainda que a opção metodológica seja por um modelo orientado à emancipação dos sujeitos envolvidos. O educador se vê inserido em uma teia formada de processos hierárquicos, coercitivos e excludentes que determinam o que é permitido ou não no contexto escolar. Em outras palavras, muitas vezes o docente se sente obrigado a aceitar direcionamentos que legitimam este "engessamento".

Para refletir sobre este processo, recorremos à ordem discursiva de Michel Foucault (2008), autor que apresenta a hipótese, segundo a qual o discurso utiliza determinados mecanismos de controle, legitimando a noção de que "a produção do discurso é ao mesmo tempo controlada, selecionada, organizada e redistribuída por certo número de procedimentos que tem por função conjurar poderes e perigos, dominar seus acontecimentos aleatórios" (FOUCAULT, 2008:8-9).

Para Foucault, os relatos são práticas que compõem a realidade, ou seja, determinam hierarquias, distinções e estabelecem o que "pode" ou "não pode" ser dito. O autor, em $A$ ordem do discurso, introduz o estudo do poder como instrumento de análise ao tratar da explicitação dos saberes. Enfim, sua investigação está centralizada nas relações entre as atitudes discursivas e os poderes que as atravessam.

Há que se considerar o ordenamento linguajeiro no âmbito do complexo administrativo que fiscaliza as instituições escolares, que por meio de programas educativos estabelece situações pedagógicas e planos de ensino. O francês (2008:44-45) entende que o sistema educacional já é uma maneira de manter ou modificar a apropriação de dizeres, com os saberes e poderes que trazem consigo.

O que é afinal um sistema de ensino senão uma ritualização da palavra; senão uma qualificação e uma fixação dos papeis para os sujeitos que falam; senão a constituição de um grupo doutrinário ao menos difuso; senão uma distribuição e uma apropriação do discurso com seus poderes e seus saberes?

O entendimento da escola como espaço mediativo intercruzado por novas linguagens e modos de comportamento e a noção de que os modelos educacionais formais são constituídos por três eixos básicos: hierarquia, coerção e exclusão, são tópicos que Adilson Citelli apresenta em Comunicação e Educação: a linguagem em movimento.

$\mathrm{Na}$ pesquisa, Citelli aponta a necessidade de análises mais aprofundadas acerca da organização de conteúdos, no caso: Parâmetros Curriculares Nacionais (PCNs), e planos de ensino estabelecidos, o pesquisador reflete sobre como os documentos oficiais se tornam 
manuais pelo fato de discorrerem objetivos, competências e avaliações, além de definirem estratégias com exigências por meio de metas e mensuração de resultados.

Pela via da estrutura escolar, considerando sua lógica institucional presente, parece não existir outra forma de aprender senão tendo em mira os conteúdos como finalidades em si e que aliados a outros postos na mesma série terminariam por legitimar as unidades (de conhecimento) chamadas de disciplinas. (CITELLI, 2004:109)

Em relação à Língua Portuguesa enquanto componente curricular, as mudanças históricas ocorridas, citadas anteriormente, e a publicação dos PCN’s foram orientadores que legitimaram a inserção de inúmeras mensagens sociais circulantes.

Quanto ao documento, Citelli lembra que tem também entre seus objetivos a descentralização dos programas escolares. Entretanto, acrescenta (2004:85), nas instituições formais:

a tendência nesse tipo de escola, foi de elaborar programas educativos fechados em que não se ajustam comportamentos que possam levar à quebra das sequências hierárquicas justificadas pela lógica da melhor escolha de conteúdos e pela autoridade de quem as selecionou.

Para o autor, "neste caso, os critérios de valor e importância respondem, sobretudo, aos gestos de perpetuação e manutenção de tópicos que o discurso escolar apresenta como únicos merecedores de crédito" (2004:87-88). Em sua análise, há equívocos em determinadas linhas pedagógicas quanto a uma suposta unicidade na qual o docente assume o papel de "dono da palavra", restando ao aluno o passivo papel de receptor.

Neste sentindo, “o sintagma 'ser dono da palavra' requisita a compreensão mais aprofundada desses mecanismos, pois, ao entrar no jogo parafrásico, o professor, ele próprio, torna-se instância de reprodução discursiva". (CITELLI, 2004:91).

A seguir, um mapa conceitual ${ }^{25}$ :

${ }^{25}$ O mapa foi elaborado por Eliana Ozores em aula da disciplina Linguagem, Comunicação e Educação, ECA/USP, ministrada em outubro de 2008 por Adilson Citelli. 


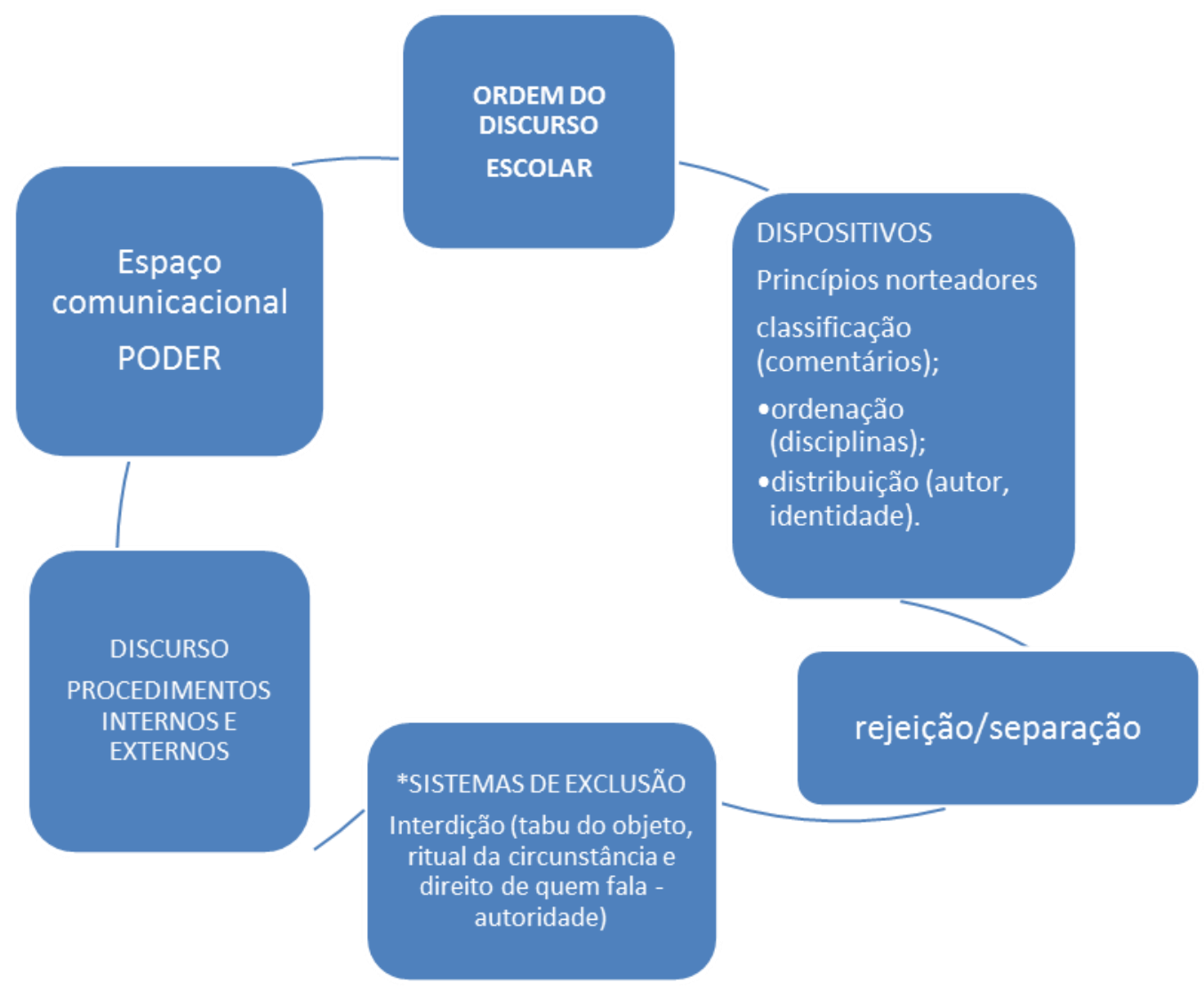

Na proposta acima, acrescentamos que nos chamados sistemas de exclusão, ou melhor, o procedimento de interdição em si, "o mais familiar", como Foucault descreve, apresenta-se composto por três tipos, formando uma espécie de jogo entre o tabu do objeto, que é a palavra proibida, o ritual da circunstância, isto é, a adequação ao sistema, e o direito de quem fala, ou seja, a "palavra de autoridade".

Este último, por sua vez, aproxima-se do conceito de "discurso competente" desenvolvido pela filósofa Marilena Chauí, para quem "tal discurso se confunde com a linguagem institucionalmente permitida ou autorizada, isto é, com uma fala na qual os interlocutores já foram, previamente, reconhecidos como tendo o direito de falar ou ouvir" (1981:7). É uma mensagem que tem o poder de fazer com que as supostas verdades da instituição, no caso do sistema de ensino, sejam expressão da verdade de todos.

Retomamos o pensamento de Citelli, pois acreditamos que, em relação aos processos de coerção, é preciso considerar a permanência dos mecanismos tradicionais no ambiente escolar. Sendo assim, por mais que a busca de consenso entre professor e aluno seja um pensamento frequente entre pesquisadores e nas teorias pedagógicas, ainda é possível 
observar, na ação didática, verdadeiros monólogos, exemplificados na obra de Chauí e constatados nas relações: coordenador-professor, diretor-coordenador e Secretaria de Educação-gestor.

Em analogia à proposta foucaultiana, pensamos em uma "ordem do discurso escolar", reconhecendo uma voz em instância superior na "pirâmide hierárquica social", iniciada na orientação instituída pela rede educacional.

\subsection{O encaminhar da pesquisa: contextos de Barueri}

Entendemos que o processo investigativo do objeto requisita a análise de algumas variáveis: o município, o sistema educacional (a rede municipal), os sujeitos (docentes de Língua Portuguesa), perpassando as estruturas curriculares, material pedagógico e índices avaliativos.

$\mathrm{Na}$ perspectiva foucaultiana, a observação destes itens, dadas as circunstâncias, estabelece indicadores quanto às possíveis práticas de controle constituídas. Desde a instância máxima, no caso a administração municipal, perpassando a unidade escolar, ou seja, os docentes e discentes em sala.

A seguir, apresentamos um organograma com estes pontos: espaço comunicacional, dispositivos, procedimentos discursivos, sistemas de exclusão etc. 


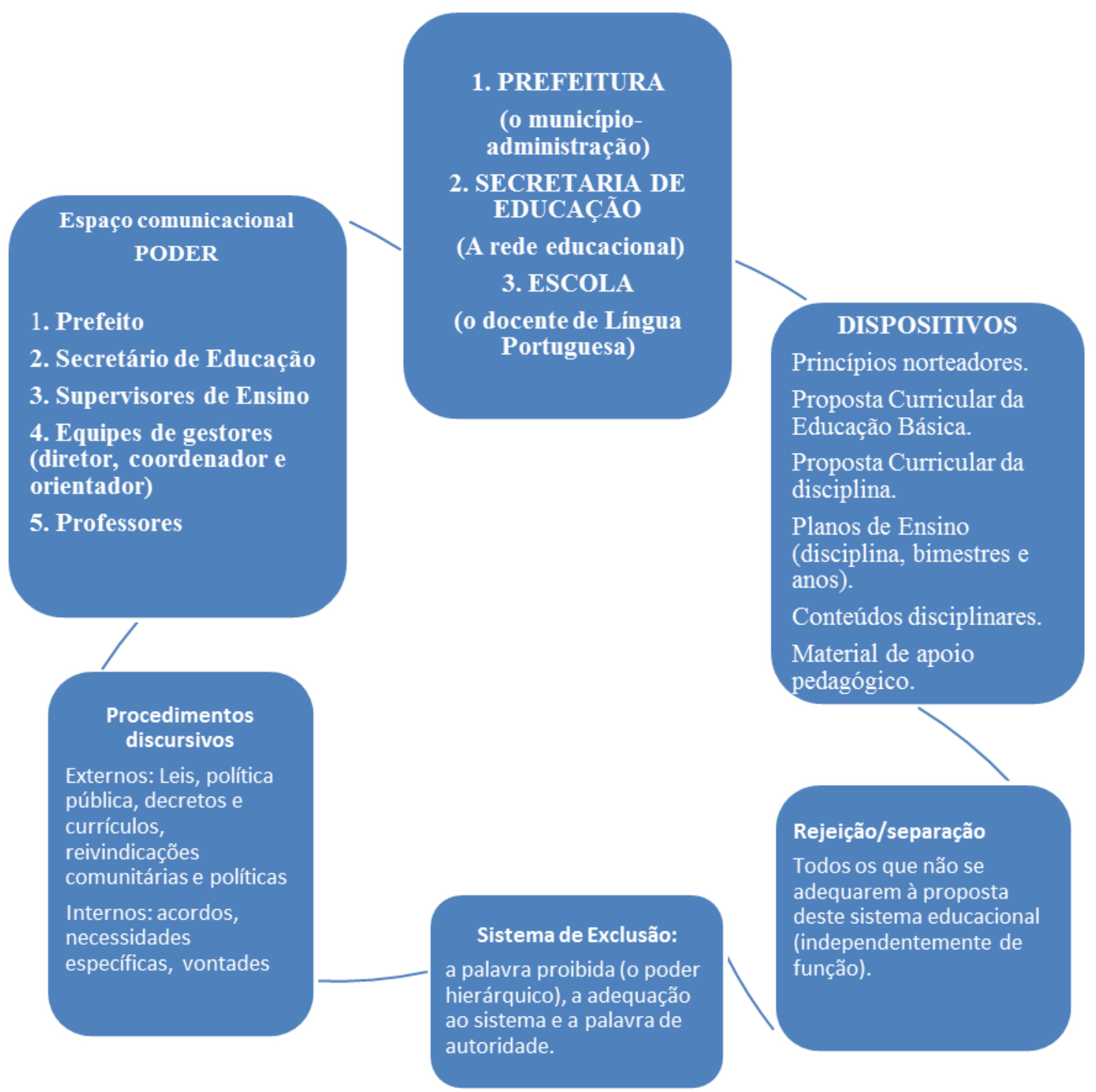

A fim de alcançarmos nosso objetivo, apresentaremos as três instâncias e os poderes constituídos: o município (a Prefeitura), a rede educacional (Secretaria de Educação) e o docente de Língua Portuguesa (a escola); em seguida, os chamados dispositivos utilizados pelo sistema: conteúdo, plano de ensino da área, proposta curricular e material de apoio pedagógico; na sequência, os procedimentos avaliativos.

\subsubsection{Barueri}

Como citado na introdução desta dissertação, o município está localizado na região oeste da grande São Paulo e possui uma população de 240.656 habitantes, de acordo com o 
Instituto Brasileiro de Geografia e Estatística (IBGE) ${ }^{26}$ censo de 2010. Faz divisa territorial com cinco municípios: ao norte, Santana de Parnaíba; ao sul, Carapicuíba; a leste, Osasco; a oeste, Jandira e Itapevi.

\section{Localização geográfica de Barueri ${ }^{27}$}

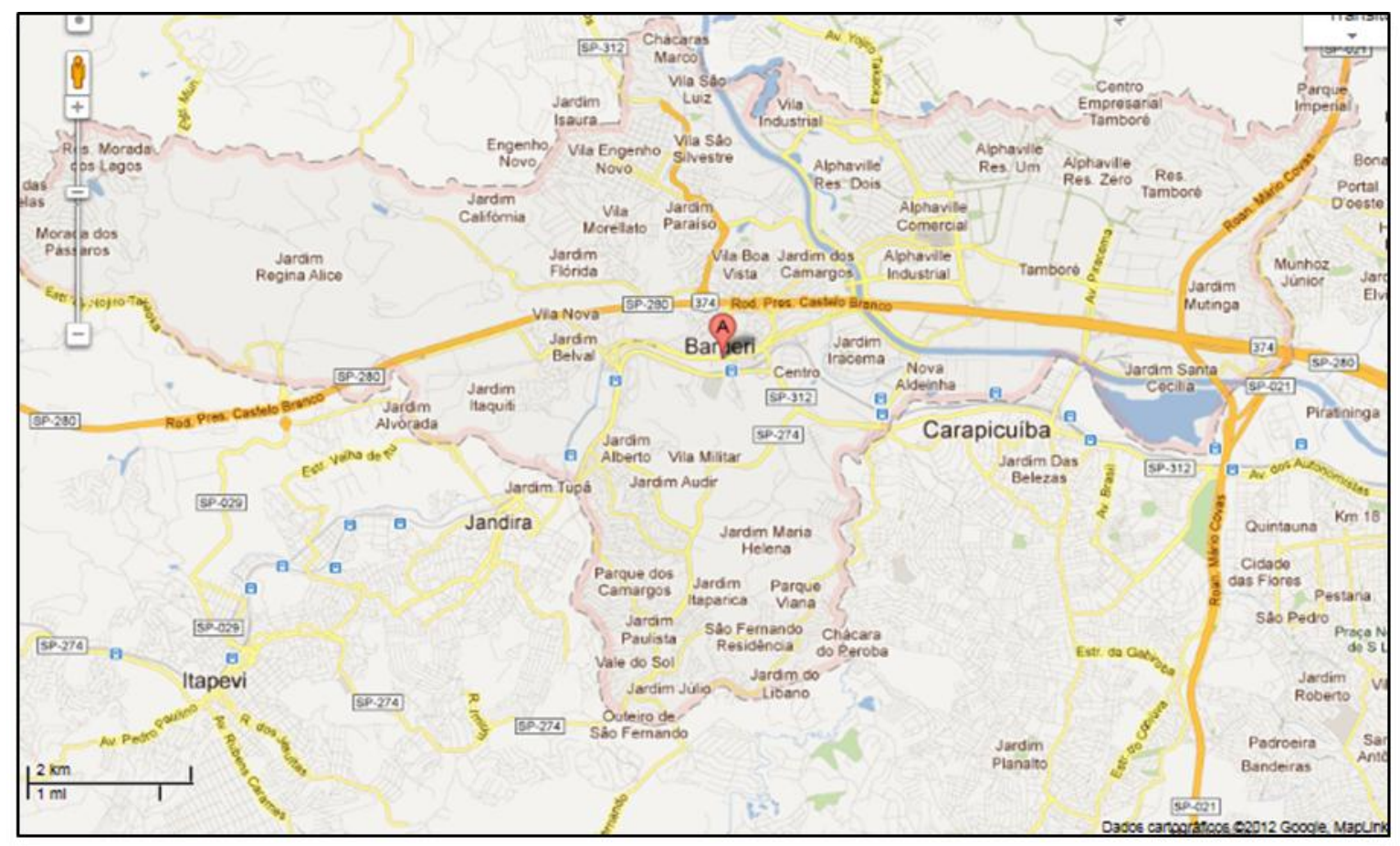

2.12.2 Caminhos desiguais: PIB, IDH e tratamento de esgoto

Barueri está incluso na chamada microrregião de Osasco, composta por oito municípios (ver tabela) e que teve população estimada em 2010 pelo IBGE em 1.775.058 habitantes.

\begin{tabular}{|l|c|c|c|}
\hline \multicolumn{1}{|c|}{ CIDADES } & POPULAÇ̃̃O (2010) & PIB R\$ (2009) & IDH (2000) \\
\hline 1) Barueri & 240.656 & $26.994 .699,700$ & 0,826 (elevado) $44^{\circ}$ \\
\hline 2) Cajamar & 64.113 & $3.764 .609,233$ & 0,786 (médio) \\
\hline 3) Carapicuíba & 369.908 & $2.672 .669,555$ & 0,793 (médio) \\
\hline 4) Itapevi & 200.874 & $2.731 .108,624$ & 0,759 (médio) \\
\hline 5) Jandira & 108.436 & $1.411 .533,399$ & 0,801 (elevado) \\
\hline 6) Osasco & 666.469 & $30.024 .366,200$ & 0,818 (elevado) \\
\hline 7) Pirapora do Bom Jesus & 15.727 & $148.772,825$ & 0,767 (médio) \\
\hline 8) Santana de Parnaíba & 108.875 & $3.068 .714,481$ & 0,853 (elevado) $7^{\circ}$ \\
\hline
\end{tabular}

${ }^{26}$ Disponível em http://www.ibge.gov.br/home/presidencia/noticias/imprensa/ppts/0000000237.pdf. Acesso em 23 de jul. de 2012.

${ }^{27}$ Imagem do município pelo Google maps. 
$\mathrm{Na}$ análise dos dados, foram considerados dois indicadores: o Produto Interno Bruto (PIB), que mensura a atividade econômica e representa a soma (valores monetários) de todos os bens e serviços finais produzidos numa determinada região (quer sejam países, estados ou cidades), e o Índice de Desenvolvimento Humano $(\text { IDH })^{28}$, que, além de renda (PIB per capita), leva em conta saúde (expectativa de vida ao nascer), educação da população e questões ambientais.

O IDH varia de zero a 1, sendo considerado: baixo, entre 0 e 0,499; médio, de 0,500 a 0,799; elevado, de 0,800 a 0,899; muito elevado, quando maior ou igual a 0,900.

Em relação a Barueri, observamos um PIB aproximado ao de Osasco (que possui quase três vezes sua população), contudo, na comparação com o IDH-M de todos os municípios de São Paulo, está na 44ª posição, distante da colocação de Santana de Parnaíba, que ocupa a sétima posição no rankig classificatório paulista e supera todas as cidades da microrregião.

Oficialmente, Barueri está dividido em 16 bairros (observar mapa). A cada um pertencem vários loteamentos. Nos limites com outras cidades existe a formação de comunidades periféricas com sérios problemas de saneamento básico e crescimento urbano desordenado, com centralização populacional em determinados bairros: Jardim Mutinga (divisa com Osasco), Belval (centro/acesso à Rodovia Castello Branco), Estrada dos Altos, Engenho Novo (divisa com Santana de Parnaíba) e Jardim Silveira (divisas com Jandira e Itapevi). Em outra ponta às margens da rodovia Castello Branco, os luxuosos residenciais com condomínios fechados, caso de Aldeia da Serra e Alphaville/Tamboré, descritos na introdução deste trabalho; sobre este último, haverá uma retomada em análises de emprego e renda.

${ }^{28}$ O Programa das Nações Unidas para o Desenvolvimento (PNUD), o Instituto de Pesquisa Econômica Aplicada (IPEA) e a Fundação João Pinheiro elaboraram e divulgaram o Índice de Desenvolvimento Humano Municipal (IDH-M) para os municípios brasileiros, numa nova edição do Atlas de Desenvolvimento Humano no Brasil para o ano 2000 (IPEA, 2003). O IDH-M é elaborado com base nos indicadores. 


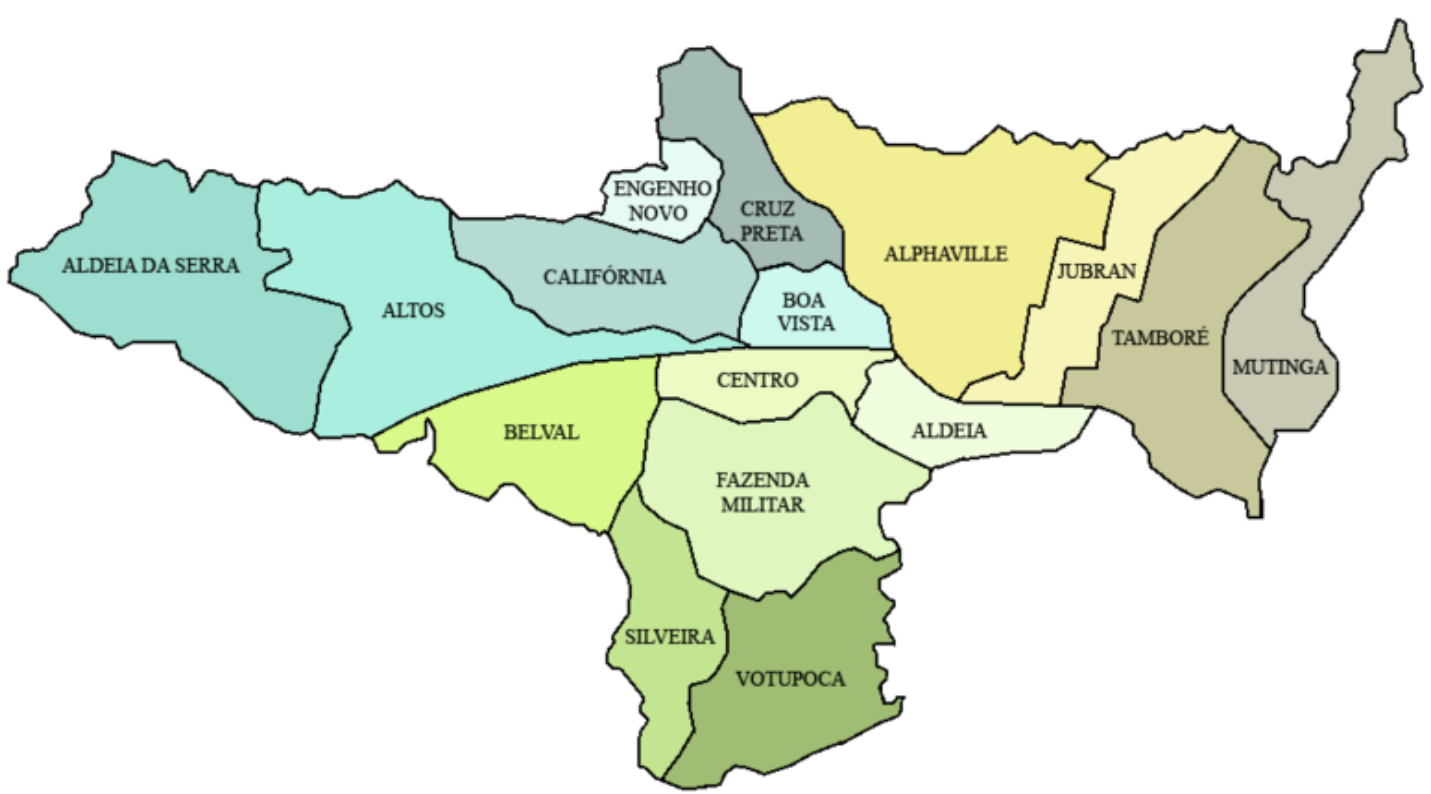

Disponível em: 〈http://www.barueri.sp.gov.br>. Acesso em 23 de jul. de 2012.

O problema da falta de tratamento do esgoto foi destaque em 2009 na imprensa local e regional, pois uma série de reportagens exibidas no telejornal "SPTV" da emissora Rede Globo de Televisão que em parceria com o Instituto de Pesquisas Tecnológicas do Estado (IPT), responsável pelo aparelho chamado de flutuador para medir o nível de poluição do Rio $\operatorname{Tietê}^{29} \cdot$, mostrou que, na época, Barueri coletava $54 \%$ do esgoto, mas não tratava nada. Apontando uma incoerência para um local que abriga a maior estação de tratamento da Companhia de Saneamento Básico do Estado de São Paulo Sabesp da região metropolitana. O referido objeto registrou no município o nível de $0,01 \mathrm{mg} / \mathrm{l}$ de oxigênio no rio Tietê, índice considerado péssimo, o que gerou vários questionamentos e entrevistas com as autoridades locais nestes programas de telejornalismo. Contudo, de acordo com dados Sabesp, até o final de 2011 eram tratados $50 \%$ do esgoto da cidade.

Em nossas breves análises com o objetivo de apresentar a realidade na qual os sujeitos estão inseridos, observamos que naturalmente problemas a serem resolvidos existem, entretanto, houve dificuldades no encontro de dados de fontes oficiais sobre o município. Por outro lado, os dados "positivos" são encontrados com maior facilidade. Sendo assim, selecionamos um indicador que tomou como parâmetro a somatória de três fatores relevantes: Educação, Saúde e Emprego e Renda. Por acompanhar anualmente o desenvolvimento

29 Dado obtido por meio de um equipamento que mede a qualidade da água em toda a extensão do rio. O flutuador, nome usado para o equipamento, iniciativa da Rede Globo com o IPT (Instituto de Pesquisas Tecnológicas do Estado), fazia parte do projeto "Rios de São Paulo", iniciado em abril de 2009. Durante todo o percurso, o flutuador foi acompanhado pelo "ecoesportista" Dan Robson, que ficava ao lado do equipamento em um caiaque. 
socioeconômico de 5.564 cidades brasileiras com base em estatísticas públicas oficiais, utilizamos como parâmetro o Índice da Federação das Indústrias do Rio de Janeiro (FIRJAN) de Desenvolvimento Municipal (IFDM). A seguir, o gráfico com a classificação dos 11 primeiros municípios no ranking nacional e estadual.

\begin{tabular}{|c|c|c|c|c|c|c|c|}
\hline \multicolumn{2}{|c|}{ Ranking IFDM } & UF & $\begin{array}{c}\text { Ranking IFDM } \\
\text { Municípios Brasileiros - } \\
\text { Ano } 2009\end{array}$ & IFDM & $\begin{array}{c}\text { Emprego \& } \\
\text { Renda }\end{array}$ & Educação & Saúde \\
\hline $1^{\circ}$ & $1^{\circ}$ & SP & Barueri & 0,9303 & 0,9184 & 0,9206 & 0,9518 \\
\hline $2^{\circ}$ & $2^{\circ}$ & SP & Paulínia & 0,9290 & 0,8954 & 0,9675 & 0,9240 \\
\hline $3^{\circ}$ & $3^{\circ}$ & $\mathrm{SP}$ & Araraquara & 0,9281 & 0,9035 & 0,9600 & 0,9207 \\
\hline $4^{\circ}$ & $4^{\circ}$ & SP & Ribeirão Preto & 0,9239 & 0,9299 & 0,9213 & 0,9207 \\
\hline $5^{\circ}$ & $5^{\circ}$ & SP & São José do Rio Preto & 0,9202 & 0,8704 & 0,9546 & 0,9356 \\
\hline $6^{\circ}$ & $6^{\circ}$ & SP & Indaiatuba & 0,9164 & 0,8631 & 0,9393 & 0,9469 \\
\hline $7^{\circ}$ & $7^{\circ}$ & SP & Marília & 0,9125 & 0,8463 & 0,9615 & 0,9297 \\
\hline $8^{\circ}$ & $1^{\circ}$ & MT & Lucas do Rio Verde & 0,9046 & 0,8849 & 0,8650 & 0,9640 \\
\hline $9^{\circ}$ & $8^{\circ}$ & SP & Taubaté & 0,8985 & 0,9013 & 0,8951 & 0,8992 \\
\hline $10^{\circ}$ & $9^{\circ}$ & SP & Itupeva & 0,8942 & 0,8979 & 0,8921 & 0,8925 \\
\hline $11^{\circ}$ & $10^{\circ}$ & SP & São Paulo & 0,8930 & 0,8799 & 0,9121 & 0,8870 \\
\hline
\end{tabular}

Disponível em: < http://www.firjan.org.br/IFDM>. Acesso em 28 nov.2011.

O indicador foi escolhido por acompanhar anualmente o desenvolvimento socioeconômico de 5.564 cidades brasileiras em três grandes áreas: Emprego e Renda, Educação e Saúde, e por se basear em estatísticas públicas oficiais disponibilizadas pelos ministérios do Trabalho, Educação e Saúde.

O documento aponta que "o município de Barueri ficou com o primeiro lugar geral no ranking paulista e também do Brasil". De acordo com o relatório, “com um histórico alto de desenvolvimento desde a primeira edição, a cidade figura entre os dez melhores resultados do país desde 2005" (FIRJAN, 2011:3).

A leitura do índice sofre variação de 0 a 1 . Quanto mais próximo do 1 , maior é o desenvolvimento da localidade. Além disso, de acordo com a metodologia, é possível determinar se a melhora relativa ocorrida em determinado município decorre da adoção de políticas específicas ou se o resultado obtido é apenas reflexo da queda dos demais municípios.

O gráfico a seguir apresenta o chamado índice consolidado de Barueri $(0,9303)$, resultante dos três fatores mencionados: Educação $(0,9206)$, Saúde $(0,9518)$ e Emprego e Renda $(0,9184)$. 


\section{BARUERI - SP (Ano 2009): IFDM 0.9303}

\section{BARUERI - SP (2009)}

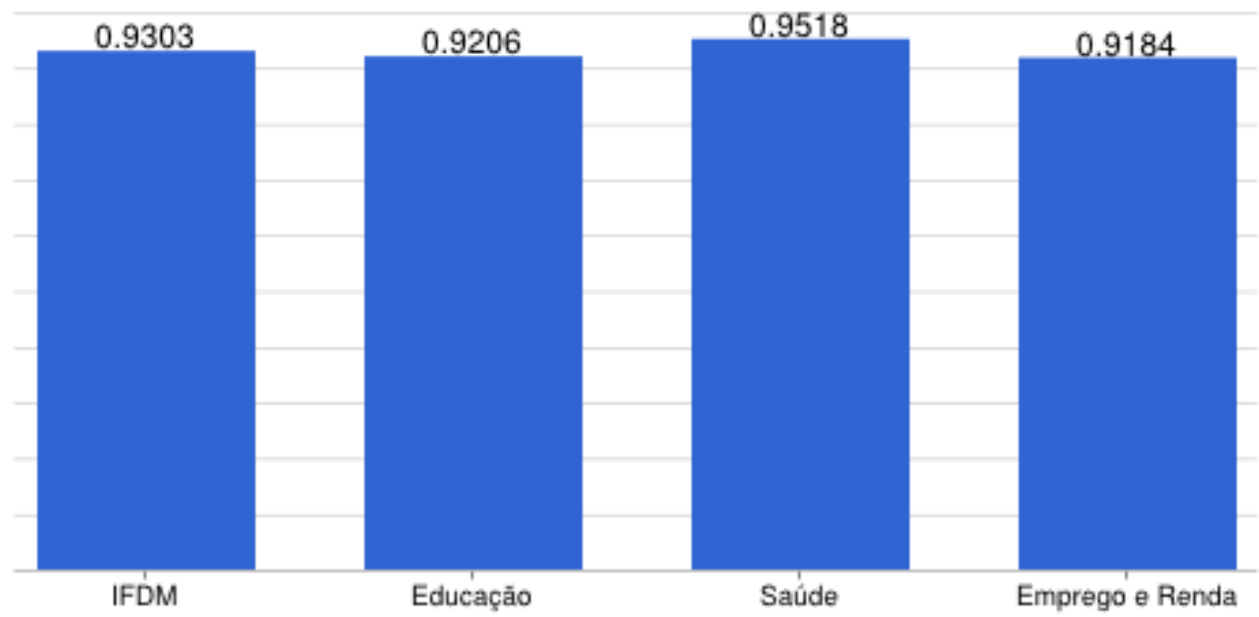

Com base nos dados apresentados acima, é possível observar que o tópico da Saúde foi o que apresentou um indice maior. Quanto à Educação, na formulação da média, o FIRJAN considerou as seguintes variáveis: taxa de matrícula na educação infantil; taxa de abandono; taxa de distorção idade-série; percentual de docentes com ensino superior; média de horas-aula diárias; resultado do Índice de Desenvolvimento da Educação Básica (IDEB) conforme dados do MEC.

O Ideb ${ }^{30}$, criado em 2007, é hoje um dos mais citados indicadores, numa escala de zero a dez, dos objetivos e mensuração da qualidade da educação brasileira. O índice, elaborado pelo Instituto Nacional de Estudos e Pesquisas Educacionais Anísio Teixeira (Inep/MEC), mostra as condições de ensino no Brasil. A partir dos resultados, o Ministério da Educação estabeleceu metas de desempenho bianuais para cada escola e cada rede até 2022.

Com o referido indicador, os sistemas municipais, estaduais e federal de ensino têm propostas a atingir. De acordo com o Ministério da Educação $(\mathrm{MEC})^{31}$, a fixação da média

\footnotetext{
${ }^{30}$ BRASIL, Ministério da Educação. IDEB. Informações disponíveis em: <http://portal.mec.gov.br/index.php?option=com_content\&view=article\&id=180\&Itemid=337>. Acesso em 12 jun. 2011.

${ }^{31}$ BRASIL, Ministério da Educação. IDEB. Informações disponíveis em:
} 
seis a ser alcançada considerou os resultados obtidos pelos países da Organização para a Cooperação e o Desenvolvimento Econômico (OCDE), conforme descrito no Saiba Mais, portal do MEC acerca do Ideb.

Com a aplicação da metodologia citada, a seguir, o índice observado e as metas projetadas para o Ensino Fundamental de Barueri.

\section{$4^{\mathrm{a}}$ série $/ 5^{\circ}$ ano}

\begin{tabular}{|c|c|c|c|c|c|c|c|c|c|c|c|}
\hline & \multicolumn{3}{|c|}{ Ideb Observado } & \multicolumn{10}{c|}{ Metas Projetadas } \\
\hline Município & 2005 & 2007 & 2009 & 2007 & 2009 & 2011 & 2013 & 2015 & 2017 & 2019 & 2021 \\
\hline BARUERI & 4.5 & 5.2 & 5.4 & 4.6 & 4.9 & 5.3 & 5.6 & 5.8 & 6.1 & 6.3 & 6.6 \\
\hline
\end{tabular}

\section{$8^{\mathrm{a}}$ série $/ 9^{\circ}$ ano}

\begin{tabular}{|l|c|c|c|c|c|c|c|c|c|c|c|}
\hline & \multicolumn{3}{|c|}{ Ideb Observado } & \multicolumn{10}{c|}{ Metas Projetadas } \\
\hline Município & 2005 & 2007 & 2009 & 2007 & 2009 & 2011 & 2013 & 2015 & 2017 & 2019 & 2021 \\
\hline BARUERI & 4.2 & 4.4 & 4.7 & 4.2 & 4.4 & 4.6 & 5.0 & 5.4 & 5.6 & 5.9 & 6.1 \\
\hline
\end{tabular}

A partir da análise dos indicadores o Ministério distribui apoio técnico e/ou financeiro aos municípios com índices insuficientes. $\mathrm{O}$ aporte de recursos foi instituído a partir da adesão dos municípios ao Compromisso "Todos pela Educação" e da elaboração do Plano de Ações Articuladas (PAR). Em Barueri ${ }^{32}$, a observação dos últimos anos de cada ciclo - Ensino Fundamental I ( $5^{\circ}$ ano) e II ( $9^{\circ}$ ano) - demonstra que as maiores defasagens estão localizadas nos anos finais do Fundamental.

Segundo o registro do MEC e o quadro de projeções da Secretaria Municipal de Educação de Barueri $^{33}$ a ser apresentado a seguir, tanto nos anos iniciais quanto nos finais do Ensino Fundamental as metas previstas para o Ideb do ano de 2011 foram atingidas em 2009.

<http://portal.mec.gov.br/index.php?option=com_content\&view=article\&id=180\&Itemid=337>. Acesso em 12 jun. 2011.

${ }^{32}$ BRASIL, Ministério da Educação. IDEB. Dados disponíveis em: <http://sistemasideb.inep.gov.br/resultados >. Acesso em 12 jun. 2011.

${ }^{33}$ BARUERI, Departamento de Planejamento. Secretaria Municipal de Educação. Dados estimados em maio de 2011. 


\section{Quadro de Projeções - IDEB municipal}

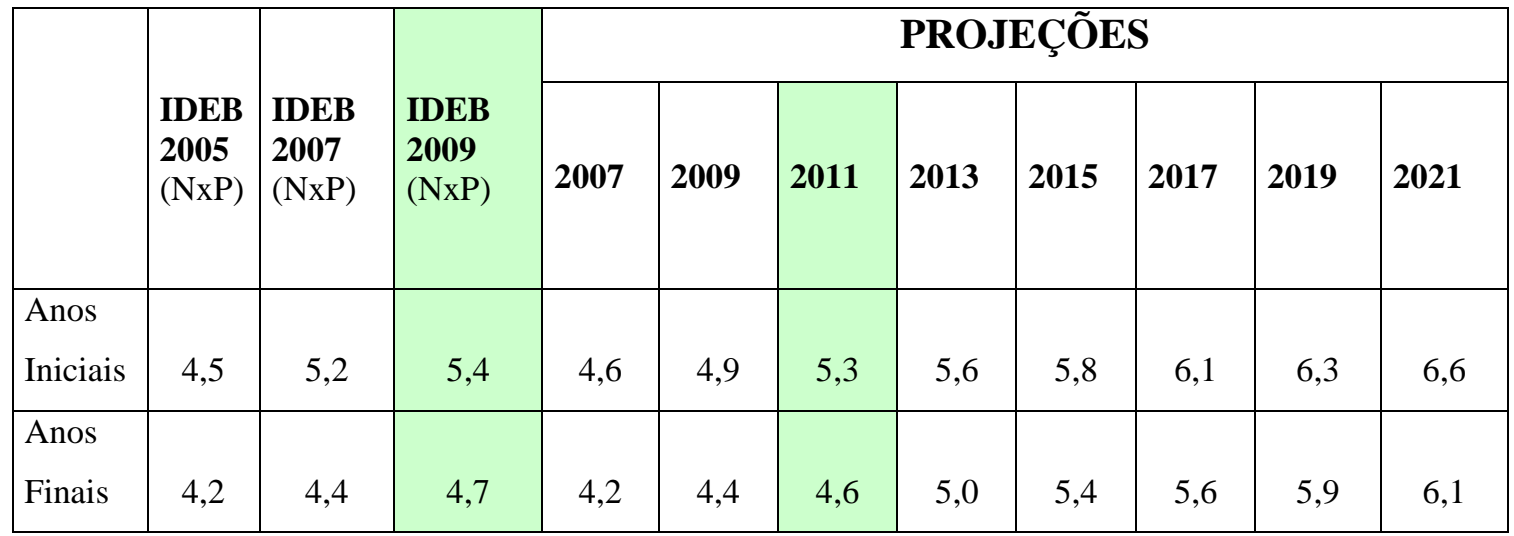

A previsão do índice (MEC) para o ano era de 4,6\% para o Fundamental I - o município atingiu 5,4\%, e para o Ensino Fundamental II era de 4,0\% - atingiu 4,7\%.

A aprovação e a média de desempenho dos estudantes em Língua Portuguesa e Matemática sintetizam o resultado, importante na visão do Ministério da Educação (MEC) quanto à qualidade de ensino avaliada pelo Ideb.

Lembramos que o indicador é calculado a partir dos dados sobre aprovação escolar, obtidos no Censo Escolar, médias de desempenho no Sistema Nacional de Avaliação da Educação Básica (Saeb) e Prova Brasil, mencionados no início de nosso trabalho.

O Instituto Nacional de Estudos e Pesquisas Educacionais Anísio Teixeira (Inep) e o MEC explicam, em página oficial, que “a Prova Brasil e o Saeb são construídos metodologicamente para avaliarem os sistemas de ensino e não os alunos ou professor" ${ }^{34}$, de acordo com o texto constante na homepage do MEC na apresentação destas avaliações ao professor.

Afinal, como já abordamos, há de se considerar a "ordem discursiva" existente acerca de metas, qualidade e, sobretudo, do sistema educacional no qual o docente está inserido.

Retomando a caracterização do índice da FIRJAN, abaixo, a trajetória do IFDM na área da Educação de Barueri e sua evolução desde 2000.

\footnotetext{
${ }^{34}$ Documento disponível em: http://provabrasil.inep.gov.br/apresentacao-professor. Acesso em 25 jun. 2011.
} 


\section{SYLLCLOANUAL - DE 2000A200S}

\section{Educação}

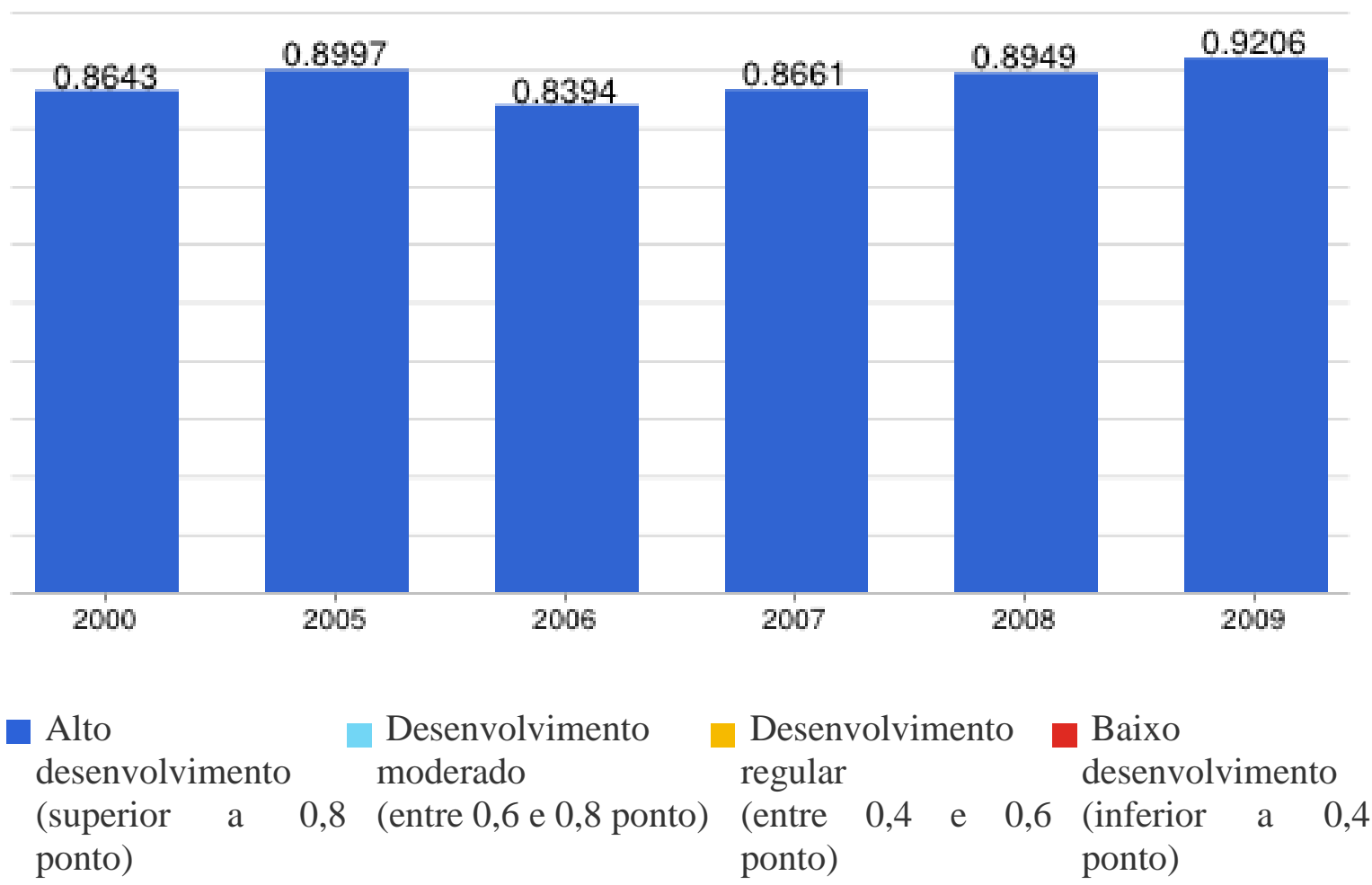

Na comparação dos seis anos analisados, verificamos as oscilações dos índices e a elevação até 2009. Ressaltamos que o mesmo indicador estabelece uma classificação para cada área. Das três investigadas, Barueri ficou em 159 lugar no tópico Educação em 2009.

Com base no índice de Emprego e Renda, entretanto, a classificação individual coloca o município em $2^{\circ}$ lugar, o que comprova sua força econômica, que se sobrepõe aos outros dois aspectos. São variáveis deste indicador: geração e estoque de emprego formal, além de salários médios. Na sequência, as variações de emprego e renda do ano 2000 até 2009. 
EYOLCLIO ANUAL - DE 2000 A200:

\section{Emprego e Renda}

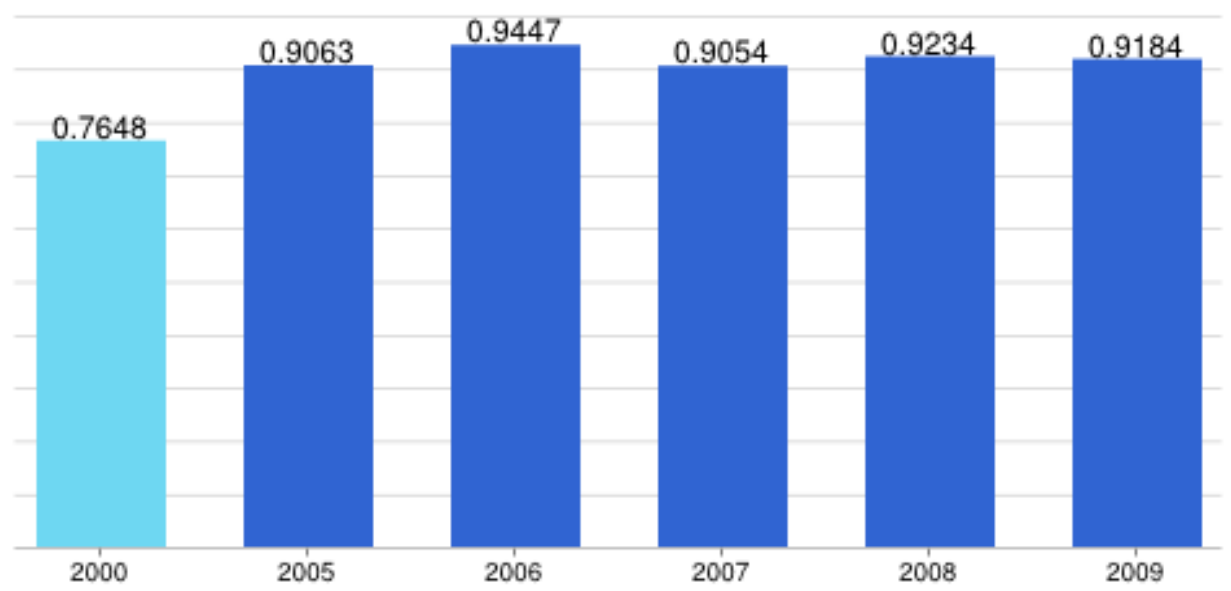

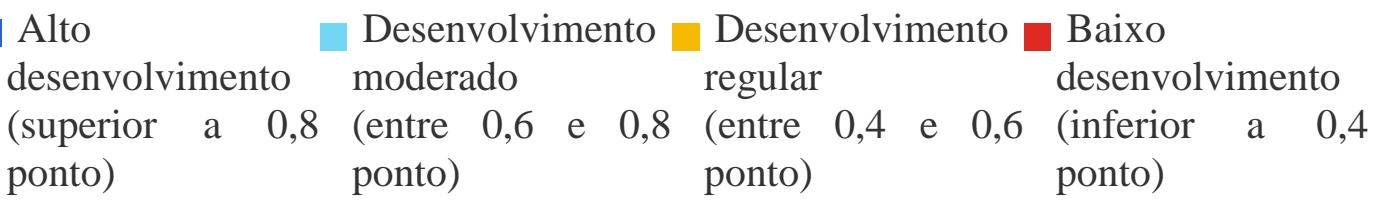

Ao tratarmos dos aspectos econômicos, é necessária a retomada da história da cidade, sobretudo do bairro de Alphaville, um complexo urbanístico idealizado e construído há 35 anos pelos engenheiros Renato Alburquerque e Yojiro Takaoka, colegas da Escola Politécnica de São Paulo (USP). De acordo com o jornal Folha de Alphaville, o bairro comporta aproximadamente 50 mil habitantes, sem contar o público flutuante de 150 mil pessoas por dia.

Como já destacado em nossa introdução, o local possui 12 condomínios residenciais fechados de alto padrão e é sede de escritórios de multinacionais (Centros Comerciais e Empresariais) geradores de impostos que subsidiam em grande parte o município.

Finalizando os indicativos das análises, de acordo com o IFDM: o ranking no aspecto Saúde classifica Barueri como o $21^{\circ}$ município do país. Segundo os dados, houve queda de 2007 a 2009, verificada no gráfico abaixo. 


\section{EVOLUCAO ANUAL - DE 2000 A $200 E$}

\section{Saúde}

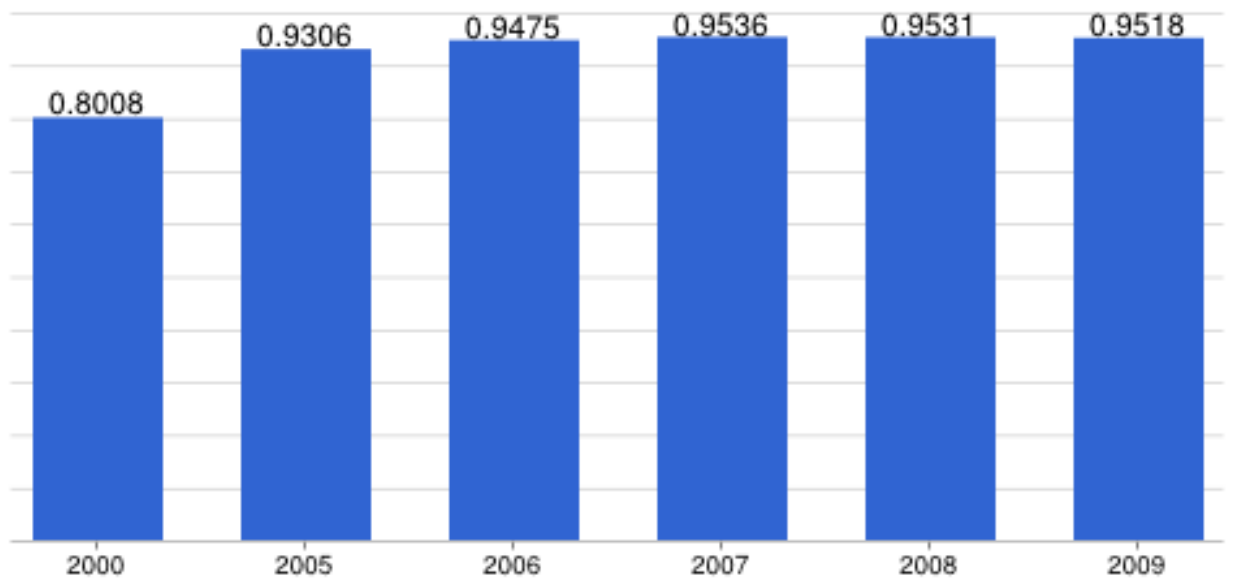

\begin{tabular}{|c|c|c|c|c|}
\hline $\begin{array}{l}\text { Alto } \\
\text { desenvolvimento }\end{array}$ & $\begin{array}{l}\text { Desenvolvimento } \\
\text { moderado }\end{array}$ & $\begin{array}{l}\text { Desenvolvimentc } \\
\text { regular }\end{array}$ & & $\begin{array}{l}\text { Baixo } \\
\text { desenvolvimento }\end{array}$ \\
\hline $\begin{array}{l}\text { uperior a } \\
\text { nto) }\end{array}$ & $\begin{array}{l}\text { (entre } 0,6 \text { e } 0,8 \\
\text { ponto) }\end{array}$ & $\begin{array}{l}\text { (entre } 0,4 \text { e } \\
\text { ponto) }\end{array}$ & & $\begin{array}{l}\text { (inferior a } \\
\text { ponto) }\end{array}$ \\
\hline
\end{tabular}

Em síntese, o município se destaca na média dos três indicadores, contudo, sua economia, no aspecto Emprego e Renda, o mantém em primeiro lugar no ranking da FIRJAN.

Após breve relato caracterizador das condições de Barueri em três grandes áreas, abordaremos a seguir, especificamente, o sistema municipal de ensino, organização na qual os sujeitos de nossa pesquisa estão inseridos.

\subsubsection{A rede educacional}

O sistema de ensino municipal abrange a Educação Infantil, Ensino Fundamental e Ensino Técnico Profissionalizante. O Ensino Médio é administrado pela Secretaria Estadual de Educação, bem como a unidade do Serviço Nacional de Aprendizagem Industrial (SENAI), a unidade da Escola Técnica Estadual (ETEC) e a Faculdade Técnica Estadual (FATEC) são administradas em parceria entre o governo estadual e o município - este último cede os prédios e funcionários para estas instituições. 
Em relação ao ensino técnico municipal, com seis unidades, é mantido pela prefeitura por meio da Fundação Instituto de Educação de Barueri (Fieb), que administra a Escola de Ensino Fundamental, Médio e Técnico Maria Theodora Pereira de Freitas, localizada no bairro de Alphaville.

Quadro de alunos por segmento educacional do município ${ }^{35}$

\begin{tabular}{|l|r|r|}
\hline \multicolumn{1}{|c|}{ Modalidade } & \multicolumn{1}{c|}{ Classes } & \multicolumn{2}{c|}{ Alunos } \\
\hline EMM & 320 & 5876 \\
\hline EMEI & 169 & 8640 \\
\hline EMEF / EMEIEF & 1456 & 46161 \\
\hline TOTAL & $\mathbf{1 9 4 5}$ & $\mathbf{6 0 6 7 7}$ \\
\hline
\end{tabular}

\begin{tabular}{|l|l|c|c|c|}
\hline \multicolumn{2}{|c|}{ SECRETARIA DE EDUCAÇÃo } & $\begin{array}{c}\text { No de } \\
\text { Escolas }\end{array}$ & $\begin{array}{c}\text { No de } \\
\text { Alunos }\end{array}$ & \multirow{2}{*}{ TOTAL } \\
\hline \multirow{2}{*}{ Educação Infantil } & Maternal & 24 & 5876 & \\
\cline { 2 - 4 } & EMEI & 18 & 8640 & \multirow{2}{*}{$\mathbf{1 4 . 5 1 6}$} \\
\hline \multirow{2}{*}{$\begin{array}{l}\text { Eunsino } \\
\text { Fundamental }\end{array}$} & EMEIEF & 07 & \multicolumn{2}{|c|}{} \\
\cline { 2 - 4 } & EMEF & 49 & 46.161 & \multirow{4}{*}{$\mathbf{4 6 . 1 6 1}$} \\
\cline { 2 - 4 } & EMEF Integral & 04 & 1973 & \\
\hline Total & & $\mathbf{1 0 2}$ & Geral & $\mathbf{6 0 . 6 7 7}$ \\
\hline
\end{tabular}

\subsubsection{O docente de Língua Portuguesa}

A rede municipal possui 195 professores especialistas de Língua Portuguesa ativos que lecionam do $6^{\circ}$ ao $9^{\circ}$ ano do Ensino Fundamental. Estes docentes são obrigatoriamente concursados e licenciados em Letras - a maioria em Inglês/Português e alguns em Espanhol/

\footnotetext{
${ }^{35}$ BARUERI, Depto de Planejamento. Secretaria Municipal de Educação. Dados estimados em maio de 2012.
} 
Português. Estes atuam nos Institutos Técnicos de Barueri (ITBs) e em escolas de tempo integral, pois a grade curricular destas instituições (ver anexo) contempla a Língua Espanhola. Em 2011, especificamente no $1^{\circ}$ semestre, os professores realizaram o Horário de Trabalho Coletivo (HAC), semanalmente, no Centro de Aperfeiçoamento de Professores (CAP), espaço destinado a cursos de formação docente, localizado na Secretaria Municipal de Educação. Os cursos consistiram em encontros com palestrantes sobre três temáticas propostas: planejamento, abordagem pedagógica e projetos de trabalho. No $2^{\circ}$ semestre, houve uma reformulação, a pedido dos professores ao Secretário Municipal de Educação, e os docentes foram divididos por áreas (Língua Portuguesa, Matemática, Ciências etc.) e segmentos do Ensino Fundamental I e II e Educação Infantil. A frequência no CAP se tornou quinzenal e os encontros foram mantidos neste formato até o final do ano.

\subsubsection{Os conteúdos e planos da área}

Quanto aos conteúdos, os docentes da rede utilizam como parâmetros de orientação: o plano de ensino anual (dividido em bimestres), a proposta curricular e os cadernos de apoio pedagógico da disciplina para cada ano de ensino.

Por isto, realizamos um breve recorte de cada um desses documentos oficiais do município com vistas a delimitarmos o currículo com base no qual os professores desenvolvem a atividade profissional.

Anualmente são fixados pela rede municipal de Educação os planos de ensino. Ao professor, cabe preencher alguns dados e objetivos gerais. Estas propostas são elencados pela Secretaria Municipal de Educação a cada ano, com a validação de alguns professores de cada área (ver anexos $A$ e $B$ ).

\subsubsection{Proposta Curricular no Ensino Fundamental}

O Currículo de Língua Portuguesa do Ensino Fundamental de Barueri, publicado em 2010, está dividido em dois volumes. De acordo com o documento oficial, "visa a apoiar o projeto educativo existente nas unidades escolares municipais e nortear o processo de ensino e aprendizagem com referências teóricas e sugestões para a organização e elaboração de propostas didáticas desta disciplina"36.

\footnotetext{
${ }^{36}$ BARUERI, Plano de Referência para a educação básica: Língua Portuguesa. Barueri: Editora Traço, 2010. p.3.
} 
$\mathrm{Na}$ introdução, a proposta reforça a concepção de que o professor é "peça fundamental para o alcance de um ensino de qualidade", pelo fato de que é por sua mediação que o aluno construirá os conhecimentos.

Nesta base curricular, a linha pedagógica pauta-se pelos princípios orientadores dos PCNs e estabelece aos alunos atividades progressivas na oralidade, leitura e escrita para garantir a compreensão da realidade, acesso, compreensão das informações e uso dos meios de comunicação em seu contexto. Consta, na proposta, um quadro denominado "sugestão de gêneros", com textos orais e escritos do $1^{\circ}$ ao $9^{\circ}$ ano do Ensino Fundamental e indicações dos gêneros textuais para cada ano.

Optamos por um recorte do referido quadro, apenas nos anos inclusos em nossa pesquisa: o chamado "ciclo final" - $8^{\circ}$ e $9^{\circ}$ anos do Ensino Fundamental.

Durante todo o período letivo do $8^{\circ}$ ano são propostos os gêneros do jornalismo, sem menção ao publicitário. Em contrapartida, no $9^{\circ}$ ano, especificamente no $2^{\circ}$ bimestre, são sugeridos "textos publicitários", fato que constatamos ao verificar os Cadernos de Apoio Pedagógico $^{37}$.

\section{Sugestão de gêneros ${ }^{38}$ - Textos orais e escritos}

\begin{tabular}{|c|c|c|}
\hline & $8^{\circ}$ ANO & $9^{\circ}$ ANO \\
\hline $1^{\circ}$ BIMESTRE & $\begin{array}{l}\text { Notícia, Entrevista, Reportagem (gráficos e } \\
\text { tabelas). }\end{array}$ & Conto, Crônica. \\
\hline $2^{\circ}$ BIMESTRE & Carta Argumentativa, Editorial. & $\begin{array}{l}\text { Carta Argumentativa, Texto } \\
\text { Publicitário. }\end{array}$ \\
\hline $3^{\circ}$ BIMESTRE & $\begin{array}{l}\text { Crônica, Sinopse, Resenha ou Resumo } \\
\text { Crítico. }\end{array}$ & $\begin{array}{l}\text { Romance e Resenha. } \\
\text { Dissertação expositiva. }\end{array}$ \\
\hline $4^{\circ}$ BIMESTRE & Caricatura, Biografia, Cartum e Charge. & $\begin{array}{l}\text { Dissertação Argumentativa. } \\
\text { Texto instrucional. }\end{array}$ \\
\hline
\end{tabular}

\footnotetext{
${ }^{37}$ O material didático distribuído aos alunos da rede municipal, os chamados "Cadernos de Apoio", da disciplina de LP, segue a distribuição dos gêneros de acordo com o referido documento.

38 Recorte do quadro intitulado: "sugestão de gêneros (textos orais e escritos) do $1^{\circ}$ ao $9^{\circ}$ ano do Ensino Fundamental" estabelecido na Proposta Curricular de Língua Portuguesa, no Plano de Referência para a Educação Básica do município de Barueri.
} 
2.12.7 As novas tecnologias na escola na Proposta Curricular de Língua Portuguesa (LP)

Na proposta da disciplina, existe um tópico chamado de "novas tecnologias na escola", que discorre sobre o uso das tecnologias na organização do trabalho pedagógico. O texto cita José Manuel Moran (2007) em A educação que desejamos, novos desafios e como chegar lá sobre a importância do professor mediador no despertar da consciência dos alunos para que saibam que o ambiente virtual não garante qualidade, mas amplia imensamente as condições de aprender, de acesso, de intercâmbio e atualização.

A questão da interface entre Comunicação e Educação é abordada no documento:

Diante das novas tecnologias, com ampla utilização da imagem e dos meios de comunicação, exige-se um novo trabalho pedagógico e um novo papel do professor. Desde as décadas de 70 e 80 as Ciências da Comunicação pesquisam essa área de interface da Comunicação com a Educação, denominada de Educomunicação. (BARUERI, 2010:77)

De acordo com a proposta curricular de informática educacional de Barueri, desde a década de 90, o município começou a estabelecer algumas parcerias e projetos-piloto nas escolas municipais, bem como a projetar laboratórios de informática. Entre os anos 2000 e 2001 os professores e gestores passaram por capacitações, promovidas em parceria com a Escola do Futuro da Universidade de São Paulo (USP).

A partir de 2008, os coordenadores do material didático pedagógico da rede municipal, os "cadernos de apoio", passaram a apresentar uma proposta para incentivar o uso dos computadores e suas tecnologias na educação; este plano de ação continha as seguintes estratégias de atuação:

os cadernos de apoio pedagógico passam a contemplar as atividades a serem desenvolvidas no laboratório de informática com a utilização de recursos da internet, de forma articulada aos conteúdos tratados no material; o desenvolvimento de um portal pedagógico destinado à conexão entre professores, Centro de Aperfeiçoamento de Professores (CAP) e Secretaria Municipal de Educação; a estruturação de um espaço destinado à reflexão contínua sobre os usos das TICs no ambiente escolar. (BARUERI, 2010:09) 
O documento oficial menciona, ainda, que "os desafios são grandes, porém, o enfrentamento é necessário". Sob esta perspectiva, a redução do espaço da sala de aula a giz e lousa, em pleno século XXI:

é insuficiente para contemplar as expectativas e necessidades dos alunos, o que implica numa necessidade de ressignificação do espaço escolar. Sendo assim, o desenvolvimento de projetos transdisciplinares mediados pelas NTICs emerge como possibilidade viável à aplicação de uma prática pedagógica inovadora. (BARUERI, 2010:18)

\subsubsection{Material pedagógico}

O caderno de apoio pedagógico é elaborado na própria Secretaria de Educação, há cerca de seis anos. Este material é dividido em dois semestres letivos e contempla todas as disciplinas do currículo da rede municipal, sendo cada disciplina dividida em unidades de estudo. Essas unidades didáticas seguem, rigorosamente, a proposta do plano de ensino anual e, concomitantemente, a proposta curricular da área para o respectivo ano.

As unidades de estudo seguem uma ordem padronizada, em caixas de trabalho. No caso da Língua Portuguesa, seguem a seguinte orientação:

1. Texto (Apresentação inicial: o texto abre a unidade);

2. Vocabulário (palavras retiradas do texto);

3. Interpretação de texto;

4. Estudo do texto (explicitações sobre a estrutura do gênero abordado);

5. Gramática (contextualizada na temática do texto);

6. Ortografia (contextualizada no texto);

7. Produção Textual (produção do gênero proposto na unidade);

8. Informática Educacional (atividades sugeridas para o uso de laboratório de informática sobre o gênero estudado).

Estas caixas direcionam toda a unidade de estudo em Língua Portuguesa. O sistema educacional não fixa prazo ou obrigatoriedade para o uso do material, que é considerado mais um apoio aos docentes, porém, pelo fato de seguir a organização dos planos de ensino para a área, torna-se legitimado como referencial para o trabalho em sala de aula. 
Isso foi comprovado em nossas avaliações quando, muitas vezes, algum gênero de texto ou atividade proposta é solicitado, sem estar inserido no material de apoio, são geradas discussões e comentários entre os docentes. Isso foi observado em nossas avaliações, pois quando algum gênero de texto ou atividade era proposta sem constar no material de apoio, muitas vezes eram geradas discussões e comentários entre os docentes.

2.12.9 A avaliação externa como quesito de qualidade

A chamada avaliação externa da rede municipal é reflexo da hierarquização de conteúdos já destacada por Adilson Citelli, pois avalia qualitativa e quantitativamente o sistema.

O Decreto Municipal $\mathrm{n}^{\circ}$ 7.082, de 26 de abril de 2011, em seu capítulo I, sobre a avaliação dos alunos, "regulamenta o artigo $3^{\circ}$ da Lei $n^{\circ} 1.689$, de 13 de novembro de 2007" a Lei discorre, no inciso II, sobre os alunos anos/séries que serão avaliados "por intermédio de provas objetivas, de múltipla escolha, sendo que todas elas envolverão o conjunto de matérias desenvolvidas dentro da correspondente grade curricular, com ênfase nas disciplinas de língua portuguesa e matemática"39. Essas avaliações são aplicadas em duas etapas, uma em cada semestre do ano.

\subsubsection{A avaliação mensal in loco}

A chamada avaliação in loco ou de campo é realizada mensalmente em todas as escolas da rede municipal com o objetivo de analisar desde o ambiente escolar até os aspectos pedagógicos. Os pedagogos e psicopedagogos são os responsáveis pela verificação da evolução do quadro institucional e pedagógico da unidade escolar com a elaboração de um relatório diagnóstico que permita a leitura das necessidades de cada escola. Cada relatório diagnóstico atribui, mensalmente, a pontuação da escola e, ao final, os pontos obtidos serão somados para compor a "nota semestral".

\footnotetext{
${ }^{39}$ Decreto Municipal $n^{\circ} 7.082$, de 26 de abril de 2011.
} 


\section{HIPÓTESES}

A problemática teórica da pesquisa é a base para a formulação de suas hipóteses e a função das hipóteses é, de acordo com Lopes (2005:140), "fornecer uma conexão entre teoria e investigação, teoria e fato" para, então, abrir caminhos para uma estratégia de investigação. Acreditamos na importância de estabelecer as hipóteses centrais, mais abrangentes, e as secundárias, mais específicas.

\section{Hipóteses centrais:}

- O professor de Língua Portuguesa tem dificuldades de acesso e infraestrutura em sua prática pedagógica para trabalhar a diversidade da linguagem jornalística e publicitária, o que contribui para que as linguagens da comunicação da cultura escrita sejam preferidas.

- O professor de Língua Portuguesa, ao trabalhar com linguagens, acompanha as mudanças tecnológicas e as insere em suas aulas.

- O professor de Língua Portuguesa não faz observações quanto à questão da recepção e considera o perfil dos alunos adolescentes de maneira homogênea, sem perceber que as novas tecnologias e linguagens interferem na recepção das mensagens e na constituição de sentidos.

- O professor de Língua Portuguesa, ao utilizar o material de apoio pedagógico da rede municipal de Barueri, distribuído a todos os alunos, não faz uso de outras alternativas quanto à aplicação de atividades das linguagens jornalística e publicitária em sala de aula.

\section{Hipóteses secundárias:}

- A disponibilização dos "cadernos de apoio pedagógico" da rede municipal, a partir do $2^{\circ}$ semestre de 2011, apenas no ambiente virtual (Portal Pedagógico), é compreendida como uma estratégia importante para a prática pedagógica dos docentes de Língua Portuguesa quanto à utilização das linguagens da comunicação nos anos finais do Ensino Fundamental. 
- A proposta da migração do material pedagógico do suporte impresso para a tela é bem vista pelo professor de Língua Portuguesa. Ele vê a mudança como necessária para o trabalho em sala de aula com os adolescentes.

- As linguagens no suporte do impresso, jornalísticas e publicitárias, ainda são hegemônicas nas aulas dos professores de Língua Portuguesa no tocante à necessidade de aquisição da competência leitora e escritora dos alunos. 


\section{OBSERVAÇÃO DE DADOS}

Nosso projeto segue o modelo metodológico proposto por Maria Immacolata Vasallo de Lopes; como já anunciado, o processo de observação constitui a segunda fase da pesquisa, durante a qual o objetivo é a coleta de evidências e informações.

\subsection{Observação}

A observação está atrelada aos objetivos teóricos e práticos da investigação, em vista da necessidade de promover uma "integração metodológica entre o momento a ser realizado por meio de operações intelectuais de caráter técnico e o momento posterior da explanação a ser desenvolvida por operações intelectuais de caráter lógico” (LOPES, 2005:143). Estas operações referem-se à necessidade de integração "orgânica" entre a observação e a descrição e interpretação, o que exige do pesquisador uma estratégia de pesquisa.

A prática da chamada vigilância epistemológica, proposta por Pierre Bourdieu, é importante, considerando que por meio de técnicas, conceitos e questionamentos podemos verificar as validades das operações. Para Lopes, a observação abrange duas operações distintas: a amostragem e a coleta de dados.

\subsubsection{A amostragem}

Para delimitar o universo de investigação, utilizamos técnicas de amostragem; como enfatiza Lopes, é necessário pensar se "as técnicas de amostragem foram norteadas pelo objeto com sua problemática e as vantagens e desvantagens de cada uma" (LOPES, 2005:144).

Existem dois tipos de amostragem: a probabilística (baseada na aplicação de métodos de tratamento estatístico e métodos quantitativos de análise) e a não probabilística (a amostra é significativa e o tratamento é qualitativo). A utilização dos dois tipos é possível em uma mesma pesquisa. Com este pensamento, utilizamos a combinação das duas técnicas para abranger a dimensão da qualidade e da quantidade. A opção por essa consonância advém da necessidade de traduzir e validar os dados pesquisados para um universo amplo, no caso, o 
município. Este tipo de tratamento é importante ao abordarmos a Educação, relações humanas e sociais.

O corpus da pesquisa é formado pelas linguagens da comunicação (jornalística e publicitária) e pelos sujeitos da investigação - os professores de Língua Portuguesa dos últimos anos do Ensino Fundamental ( $8^{\circ}$ e $9^{\circ}$ anos) da rede municipal de educação de Barueri. Os dados secundários, provenientes do próprio sistema de ensino e do universo docente e discente, orientaram-nos e contribuíram para a análise e interpretação de dados.

A opção pelos especialistas de Língua Portuguesa, ou seja, licenciados em Letras com habilitação em Português/Inglês ou Português/Espanhol, dos últimos anos do ciclo final do Ensino Fundamental de Barueri foi intencional e motivada pelas exigências sobre a disciplina, em todas as esferas governamentais, e por sua importância na vida do indivíduo, responsabilidade pela construção das competências leitora e escritora dos alunos e suposta facilidade em estabelecer interfaces com as linguagens da comunicação.

A intenção inicial não era mensurar, na amostragem, a idade dos educadores para verificar a média etária e tempo de serviço dos mesmos, era de verificar como ocorre a abordagem das linguagens do circuito midiático no cotidiano profissional e, na sequência, investigar os gêneros mais utilizados e objetivos de seu uso, considerando o público a ser atingido: os adolescentes contemporâneos. Tais educandos teriam, a princípio, mais proximidade com a mídia e os recursos tecnológicos.

A população da pesquisa, na primeira etapa, contemplou 40 professores de Língua Portuguesa dos dois últimos anos do ciclo final do Ensino Fundamental ( $8^{\circ}$ e $9^{\circ}$ anos). Destes, 20 professores do $8^{\circ}$ ano e 20 do $9^{\circ}$ ano, ou seja, 40 professores do universo de 195 docentes de Língua Portuguesa ativos na rede educacional em questão.

Optamos por abranger mais de um ano escolar para estabelecer comparações e também porque o número de professores da referida disciplina no $9^{\circ}$ ano $\left(8^{a}\right.$ série $)$ construiria uma amostragem muito pequena para a pesquisa. Por isso, ampliamos o universo da pesquisa e incluímos, também, os docentes do $8^{\circ}$ ano. Por isto, foi necessário delimitar critérios e técnicas, os quais serão apresentados a seguir. 


\subsection{As técnicas de coleta de dados}

As operações de dados são verdadeiros instrumentos para a coleta de informações. De acordo com Lopes, "elas são propriamente técnicas de observação ou de investigação (questionário, entrevista, história de vida), as quais se diferenciam das técnicas de análise no caso de tabulação e classificação que se sucedem" (LOPES, 2005:146).

Para Bourdieu (1999), quanto menos consciente for a teoria implícita numa prática, teoria do conhecimento do objeto e teoria do objeto, tanto maior a possibilidade de não ser controlada e, portanto, de ser inadequada ao objeto em sua especificidade. Como é comum acontecer, ao se chamar de metodologia, o que não é senão um decálogo de preceitos tecnológicos, escamoteia-se a questão metodológica propriamente dita: a operação entre as ações.

Uma vez escolhidas, as técnicas conferem um significado epistemológico ao tratamento do objeto e um significado teórico aos problemas que se apresentam ao objeto (LOPES, 2005:146).

A etapa de observação pode ser realizada de forma direta (o investigador manipula estrategicamente sua posição e efetua o registro sistemático dos fatos ou observação participante) ou indireta (questionário, formulário, entrevista e história de vida); essas são as principais técnicas de coleta da pesquisa empírica.

Para a realização de nossa pesquisa, utilizamos a observação indireta com dois instrumentos, questionário e entrevista, que foram aplicados aos docentes e discentes.

Certamente, quando pensamos nas técnicas escolhidas, procuramos romper com o "olhar viciado" do senso comum, como exposto por Lopes, e seguir rumo a um fazer científico com base no entendimento, pois é ilusão pensarmos em uma observação neutra e sem nenhuma interferência da relação entre sujeito e objeto.

Michel Thiollent destaca que é preciso "levar em conta as pré-teorias disponíveis para construir modelos explicativos ou interpretativos a serem testados por diversos procedimentos de pesquisa" (1980:21).

Thiollent cita Bachelard quanto à crítica metodológica, pois este considerava, como critério epistemológico, que toda técnica é uma "teoria em atos". Neste sentido, cada técnica contém instrumentos particulares que requisitam pressupostos teóricos. Uma das técnicas que utilizamos em nosso trabalho, como já anunciado, é o questionário. 
De acordo com Thiollent, a aplicação de questionário obedece a regras diferentes das da entrevista aberta. "O questionário é aplicado a um conjunto de pessoas escolhidas por diversos critérios de representatividade" (THIOLLENT, 1980:33). Eles são diversificados podem conter perguntas abertas e fechadas. Outras perguntas propõem diversas alternativas entre as quais o respondente pode escolher, "segundo o procedimento de escolha múltipla" (LOPES, 2005:33). Já a pergunta aberta não tem resposta definida. A combinação de diversos tipos de pergunta está diretamente ligada aos objetivos desta pesquisa.

Após a aplicação dos questionários, percebemos a importância de também utilizarmos outra técnica de observação indireta: a entrevista. Para tanto, delimitamos um universo formado por 20 docentes e estabelecemos alguns critérios definidores na seleção dos professores para as entrevistas: o primeiro é que, dos 20 professores de Língua Portuguesa, 10 lecionassem para o $8^{\circ}$ ano e 10 para o $9^{\circ}$ ano do Ensino Fundamental.

Sobre a condução dos trabalhos por meio da técnica da entrevista, recorremos ao argumento de Michel Thiollent (1980:33) sobre o uso em profundidade:

Quando o assunto é muito aberto, o questionário é substituído por um simples roteiro de entrevista, ou, no caso da entrevista não-diretiva, por uma instrução ou tema-chave a partir do qual o respondente falará sem responder a perguntas predeterminadas. Nestes últimos casos, trata-se da entrevista propriamente dita. A diferença entre o questionário (eventualmente aplicado em entrevista dirigida) e as entrevistas semi-estruturadas e não-diretivas reside na extensividade do primeiro (grande número de pessoas e fechamento das perguntas) e na intensividade da segunda (pequeno número de pessoas e grande abertura das perguntas para maior profundidade).

De acordo com nossa problemática, a técnica da entrevista permite essa intensividade e profundidade na investigação.

O segundo critério é que os docentes deveriam pertencer às seguintes unidades escolares: 1) escolas de período integral; 2) escolas que também ofereçam o ciclo inicial do Ensino Fundamental; 3) escolas que tenham o $8^{\circ}$ ano e $9^{\circ}$ ano do Ensino Fundamental; 4) unidades escolares com laboratório de informática. 


\subsection{Relato sobre a coleta de dados}

A pesquisa de campo foi realizada em duas etapas: aplicação de questionários e realização de entrevistas presenciais. A abordagem, nos dois casos, foi diferenciada. Para a aplicação dos questionários, iniciamos o contato por meio de uma carta aberta dirigida aos gestores de cada escola solicitando a colaboração dos docentes de Língua Portuguesa dos $8^{\circ}$ e $9^{\circ}$ anos e, a estes, enviamos uma mensagem sobre os motivos do trabalho e a importância da participação deles para legitimá-lo. Em linhas gerais, o questionário possuía quatro objetivos definidos:

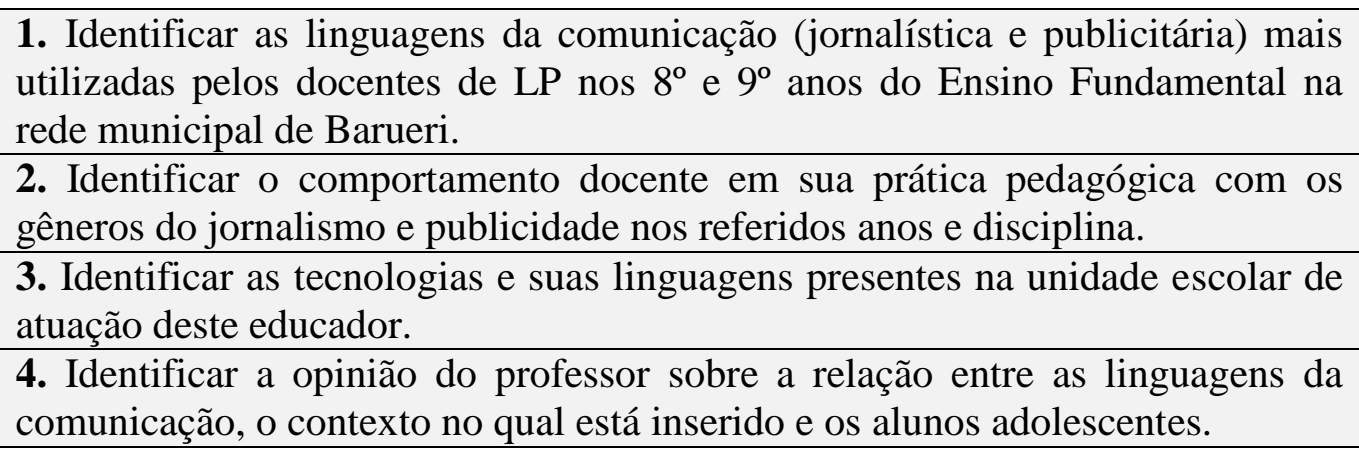

A primeira etapa aconteceu sem a presença física da investigadora, estratégia encontrada para garantir mais autonomia aos professores em suas respostas neste contato inicial, afinal, o exercício da função na Secretaria de Educação poderia intimidá-los. Após a coleta de dados, os gestores devolveram os questionários respondidos e, a partir deste instante, fizemos as análises e tabulações das informações coletadas.

Com os gráficos prontos, observamos as dúvidas, lacunas e informações incompletas, geradoras de outros pontos de vista e/ou outras perguntas causadoras de investigações acerca de nosso objeto.

Partimos, então, para a segunda fase de nosso trabalho: realizamos as entrevistas presenciais, durante os intervalos dos encontros dos docentes no Centro de Aperfeiçoamento de Professores (CAP), local em que, quinzenalmente, realizam a chamada a Hora de Atividades Coletiva (HAC).

A entrevista seria realizada nas unidades escolares, porém, os professores consultados citavam o CAP como melhor local, por conta do bom espaço físico e, sobretudo, pelo tempo disponível para tal. 
Os educadores foram solícitos e, devido à fase anterior, demonstraram interesse na temática. A resistência temida, em virtude da função profissional exercida pela pesquisadora, não ocorreu e, talvez por certa familiaridade, os educadores puderam expor as situações de forma natural, até aquelas nas quais se sentiam desprestigiados pelo sistema.

Durante as entrevistas, percebemos que o pertencimento à área educacional e a formação na área da comunicação se tornaram um item facilitador, já que em muitas entrevistas havia momentos em que comentavam: "você é da área e entende o que falo" (referindo-se à pesquisadora).

Em relação aos alunos, após as entrevistas com os docentes, aplicamos esta técnica com eles e consideramos utilizamos também outra técnica da observação indireta: os questionários. 


\section{A DESCRIÇÃO DE DADOS}

A descrição é a terceira fase da pesquisa empírica. Ela "faz a ponte entre a fase de observação dos dados e a fase da interpretação e, por isso, combina igualmente em suas operações técnicas e métodos de análise" (LOPES, 2005:149).

Para Lopes, ela é desenvolvida por meio da operação de análise realizada em dois passos: manipulação dos dados e procedimentos analíticos. Esta etapa só é possível a partir das inferências obtidas pela tabulação anterior, que permite ver o fenômeno de forma organizada e sintética: “(...) o fenômeno deixa de ser percebido como algo caótico e ininteligível e passa a ser visto em seus atributos essenciais e interdependentes, isto é, sob uma forma sintética" (2005:149).

Ao tratar dos procedimentos de organização, crítica e classificação dos dados coletados, a autora (2005) ressalta: a) a necessidade do tratamento estatístico, ou seja: elaborar tabulações para encontrar concentrações, frequências e tendências na documentação coletada; exame multivariado para efetuar relações e cruzamentos; a categorização para encontrar campos de sentido; b) assegurar o "domínio" sobre a massa de informações, pois permite identificar e selecionar fatos relevantes ao tratamento analítico ulterior; c) conseguir um conhecimento prévio das possibilidades da documentação em relação aos objetivos teóricos e práticos.

Nesta direção, inicialmente, a partir da apuração dos questionários e conteúdo, estabelecemos um recorte das temáticas mais pertinentes com base na comparação dos resultados.

A partir deste levantamento, elaboramos um roteiro de entrevistas semi-estruturadas e delimitamos o número de professores a serem entrevistados. Dessa forma, poderíamos verificar se o perfil da amostra obtido por meio dos questionários, sem a presença do pesquisador, condizia com as respostas da segunda etapa, com a presença dele.

A seguir, indicamos as principais percepções dos docentes pesquisados acerca das linguagens comunicacionais. 


\section{Tabulação de Dados: questionários}

\section{A questão da faixa etária e dos anos de magistério}

Conseguimos mensurar a média de idade e tempo de magistério dos professores pesquisados para fins de direcionamento da próxima etapa. Foi tabulado um item que não estava incluso na pesquisa, no primeiro momento, mas que acabou despertando nosso interesse por indicar algo relevante: tanto os professores do $8^{\circ}$ quanto os do $9^{\circ}$ ano da rede municipal de Barueri possuem, em média, a mesma idade e tempo de serviço.

\section{Professores de LP do $9^{\circ}$ ano do Ensino Fundamental de Barueri}

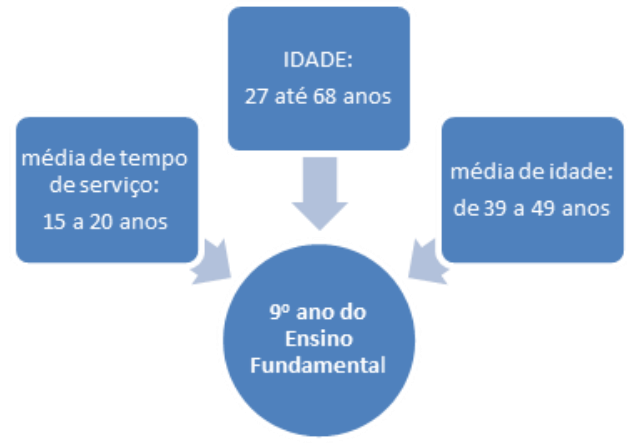

\section{Professores de LP do $8^{\circ}$ ano do Ensino Fundamental de Barueri}

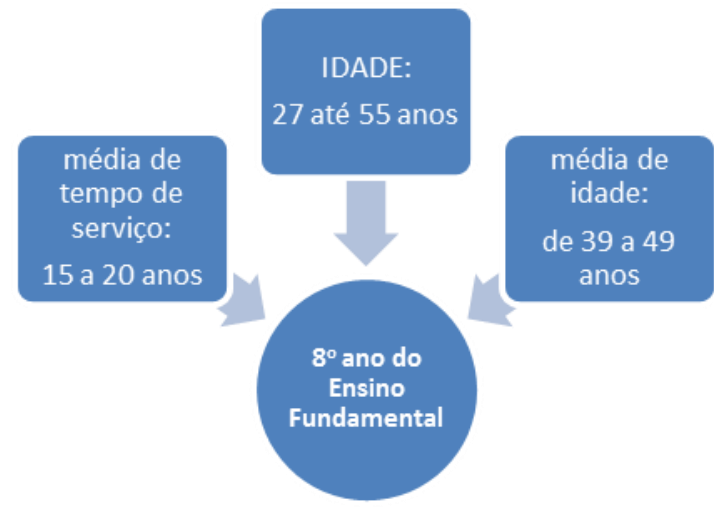

Observamos que a média de idade dos pesquisados está entre 39 e 49 anos e o tempo de magistério entre 15 e 20 anos. 


\section{Questões abertas $(15,16,17,29$ e 30)}

O questionário (ver anexo) foi composto de 30 questões, sendo cinco perguntas abertas opinativas $(15,16,17,29$ e 30), as quais não foram mensuradas na primeira etapa da pesquisa, mas foram incluídas na etapa posterior: as entrevistas.

Fizemos um recorte ${ }^{40}$ inicialmente para mensuração dos dados, ação essencial ao prosseguimento da fase de observação. Ressaltamos que várias questões aplicadas aos docentes utilizaram uma expressão pensada anteriormente à sua execução: "gêneros da comunicação impressa". Neste aspecto, em diálogos com a orientação adotamos o termo linguagens da comunicação, substituindo o anterior, por sua abrangência.

Apresentaremos a seguir o resultado da coleta dos dados, obtidos com as respostas e comentários dos professores. As porcentagens revelam a somatória das respostas dos 40 especialistas de Língua Portuguesa, também com especificidades dos anos pesquisados: $8^{\circ}$ ano (20 docentes) e $9^{\circ}$ ano (20 docentes) do Ensino Fundamental.

Em relação às perguntas fechadas realizamos a divisão de forma a contemplar as seguintes temáticas: recursos audiovisuais e tecnológicos (de 1 a 4); suportes textuais em sala de aula (5, 6 e 7); linguagens (gêneros) do jornalismo e publicidade (8 e 9); o uso e a leitura de imagens (10 e 11); material pedagógico (13); plano de ensino de Língua Portuguesa (14 e 15) e, por fim, leitura, Educomunicação e gêneros do jornalismo e publicidade (16, 17 e 18). A tabulação dos gráficos segue a sequência exposta.

\section{Equipamentos audiovisuais e tecnológicos}

\section{(Gráficos 1, 2, 3 e 4)}

Sobre os equipamentos que as unidades escolares possuem, os docentes citaram, na sequência (gráfico 1): televisão, rádio, aparelho de CD, DVD, data show e câmera digital.

Apesar do domínio dos aparelhos de TV, os dados abaixo revelam a existência de número considerável de data shows, aparato citado por $11 \%$ dos professores e que facilita a ação pedagógica com os alunos por meio de dispositivos tecnológicos.

\footnotetext{
${ }^{40}$ Este recorte de dados serve apenas para direcionamento dos objetivos de nossa pesquisa, os gráficos não seguem necessariamente a ordem apresentada nos questionários. Foram contempladas nesta amostra questões que diretamente contribuem com a pesquisa.
} 


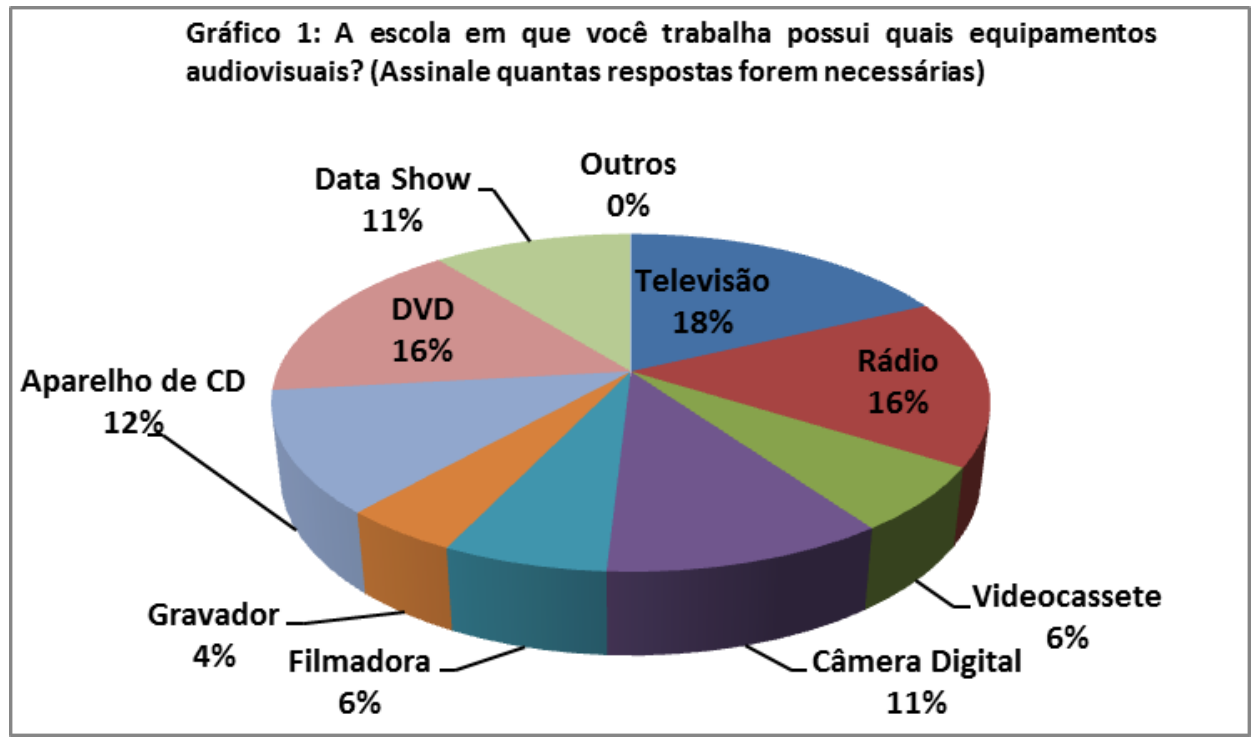

O fato de $11 \%$ dos professores citarem um equipamento de alto custo, aparentemente não tão utilizado na prática cotidiana docente, além de estar localizado, no município pesquisado, em salas específicas (laboratórios de informática, sala dos professores e até bibliotecas) provocou-nos estranheza durante a análise e nos levou a investigar novamente o dado na etapa posterior da coleta; nesta fase, os professores confirmaram a existência e o uso do aparato em $90 \%$ das escolas, devido a diversos aspectos observados, o principal deles a ausência do material impresso para os alunos.

É importante ressaltar que na rede de Barueri os chamados laboratórios de informática são tratados como espaços para utilização dos computadores pelos alunos. Ainda que várias escolas possuam computadores, data-shows, em outros espaços, oficialmente é naqueles espaços que são didaticamente localizados para uso discente. 


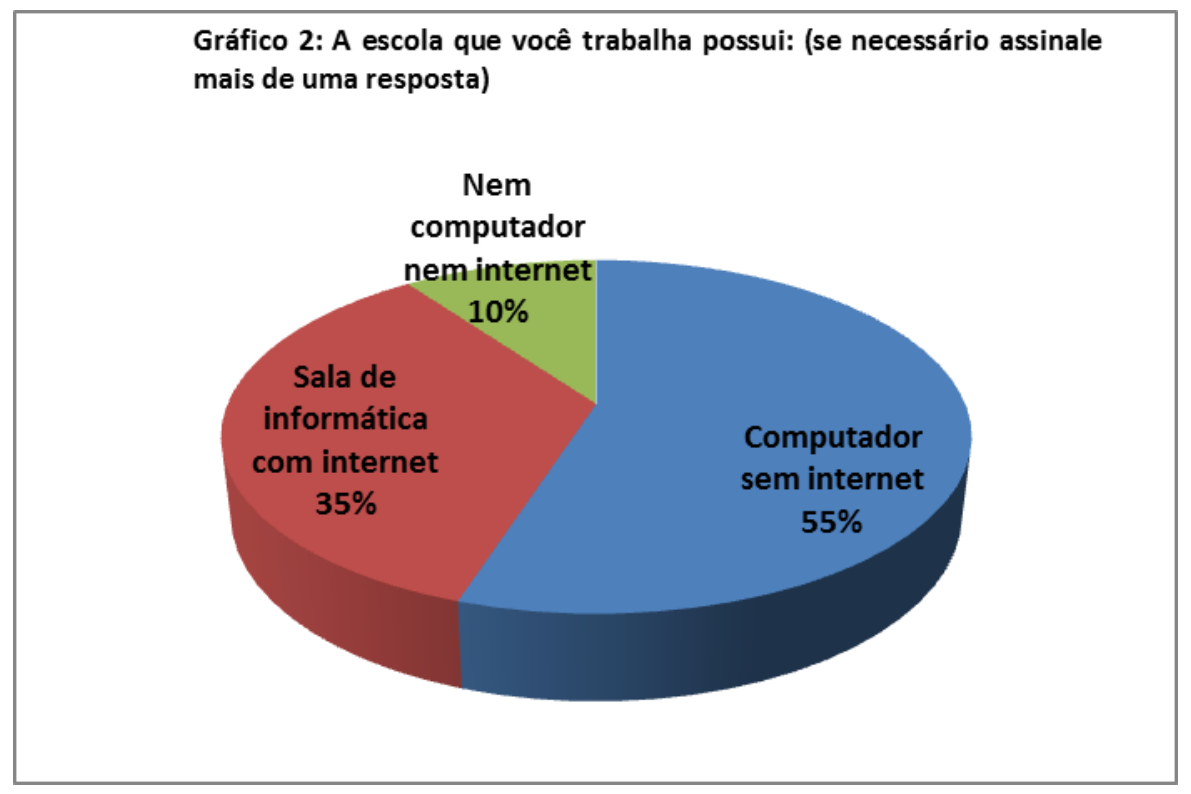

O gráfico 2 aponta que, das instituições nas quais os pesquisados atuam, ou seja, 14 unidades, mais da metade (55\%) possui computador (não necessariamente nos laboratórios), ao passo que $35 \%$ dos docentes afirmam a existência de tais salas, inclusive com internet.

Outro fato a ser considerado neste gráfico é que $10 \%$ dos professores apontaram a inexistência destas máquinas nas unidades escolares. Nas entrevistas (a serem apresentadas), investigamos se o fato de existir tal sala é garantia do uso pelos docentes de Língua Portuguesa em atividades com os alunos.

Acrescentamos a consideração de um fato atípico: a partir dos meses de fevereiro, março e abril de 2012, foram chamados, pelo departamento de Recursos Humanos da prefeitura, novos professores de informática, classificados em concurso, os quais possuem a função específica de trabalhar com os alunos neste espaço, proporcionando de certa maneira nestas instituições maiores acesso dos alunos ao espaço específico, bem como ações pedagógicas. 


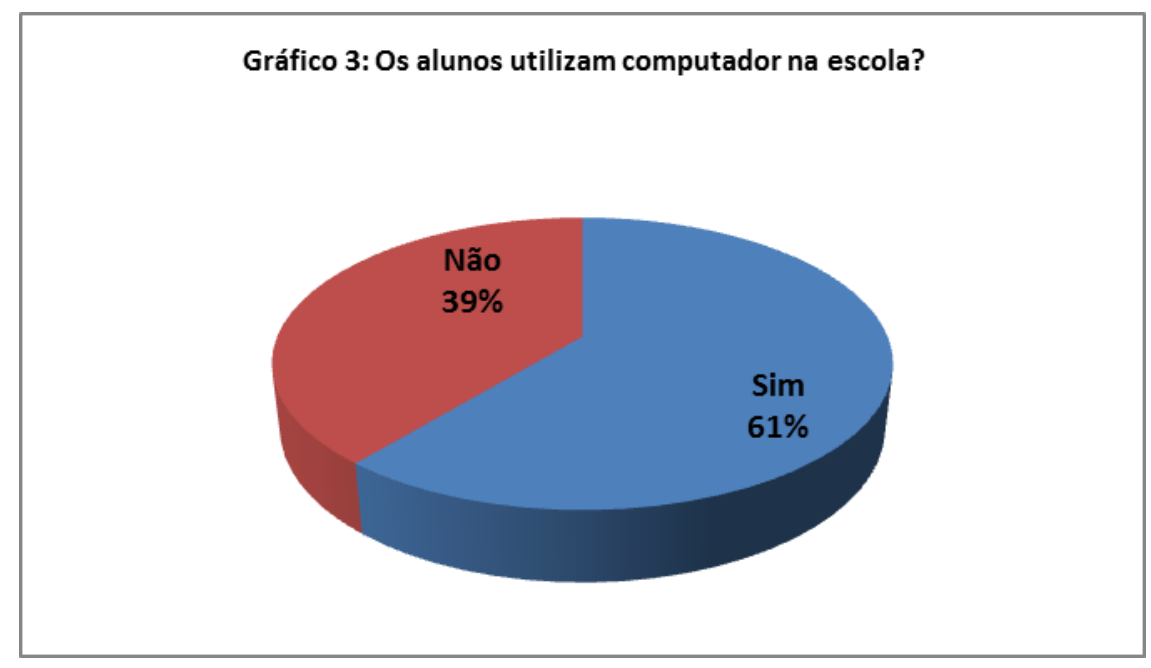

O gráfico 3 demonstra que, de acordo com os docentes, $61 \%$ dos alunos usam o computador na escola enquanto os outros 39\% não o utilizam. Estas informações, se comparadas com os dados do gráfico anterior sobre $35 \%$ das unidades escolares possuírem laboratório de informática com internet, proporcionaram o levantamento das seguintes questões: Quais seriam os reais motivos que levam os adolescentes, na visão dos docentes, a não utilizarem este equipamento? Seriam aspectos de infraestrutura ou de metodologia?

As respostas a estes questionamentos foram fornecidas pelas entrevistas; em síntese, de acordo com os professores, aspectos de infraestrutura são importantes, mas a metodologia e a disponibilização de programas atuais também o são. Na opinião dos entrevistados, não basta apenas levar os discentes até a sala, é preciso estar com um planejamento adequado e com subterfúgios capazes de chamar a atenção (motivar estes jovens) para o interesse em atividades com as linguagens comunicacionais neste espaço. 


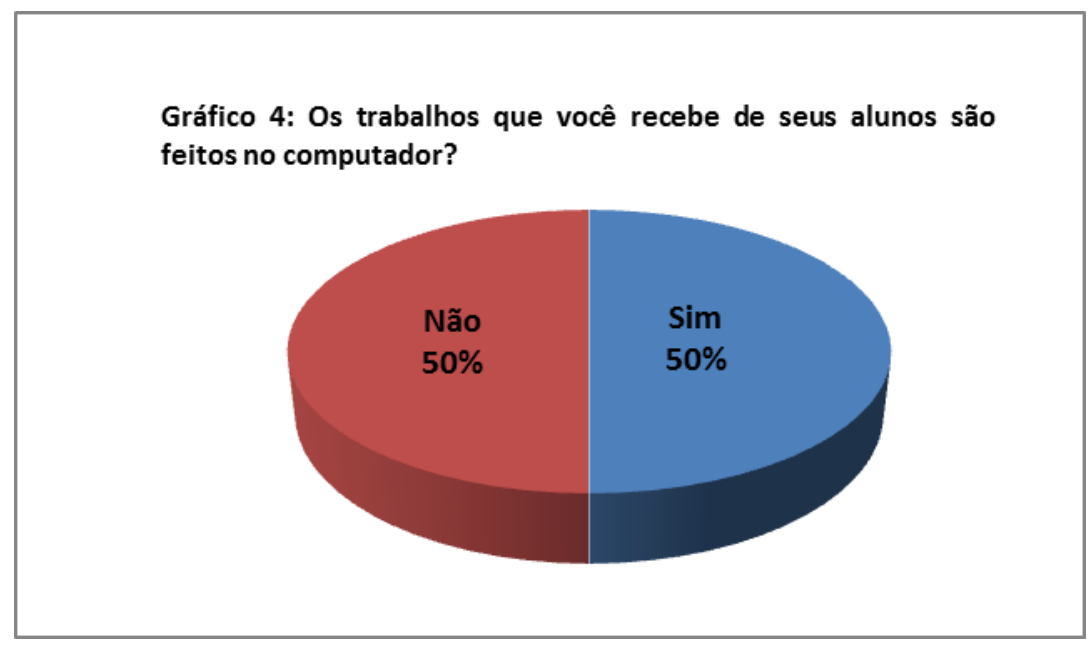

O gráfico 4 aponta um suposto empate técnico entre atividades realizadas em computador ou não pelos alunos. Nas entrevistas, esta questão foi elucidada e envolve o processo metodológico do educador. Alguns docentes de Língua Portuguesa afirmaram exigir dos alunos trabalhos manuscritos devido ao plágio, o famoso "recorte e cole", segundo eles tão comuns nas pesquisas em internet feitas pelos adolescentes.

\section{Os suportes de texto em sala de aula (Gráficos 5, 6 e 7)}

No gráfico 5, a indicação dos suportes mais utilizados pelos professores em Língua Portuguesa revela a hegemonia do material impresso, considerando os $65 \%$ que afirmam utilizá-los em suas aulas. Na época, havia ainda a opção do material de apoio pedagógico municipal distribuído aos discentes.As telas, por não havermos delimitado se de televisão ou de computador, aparecem com $20 \%$.

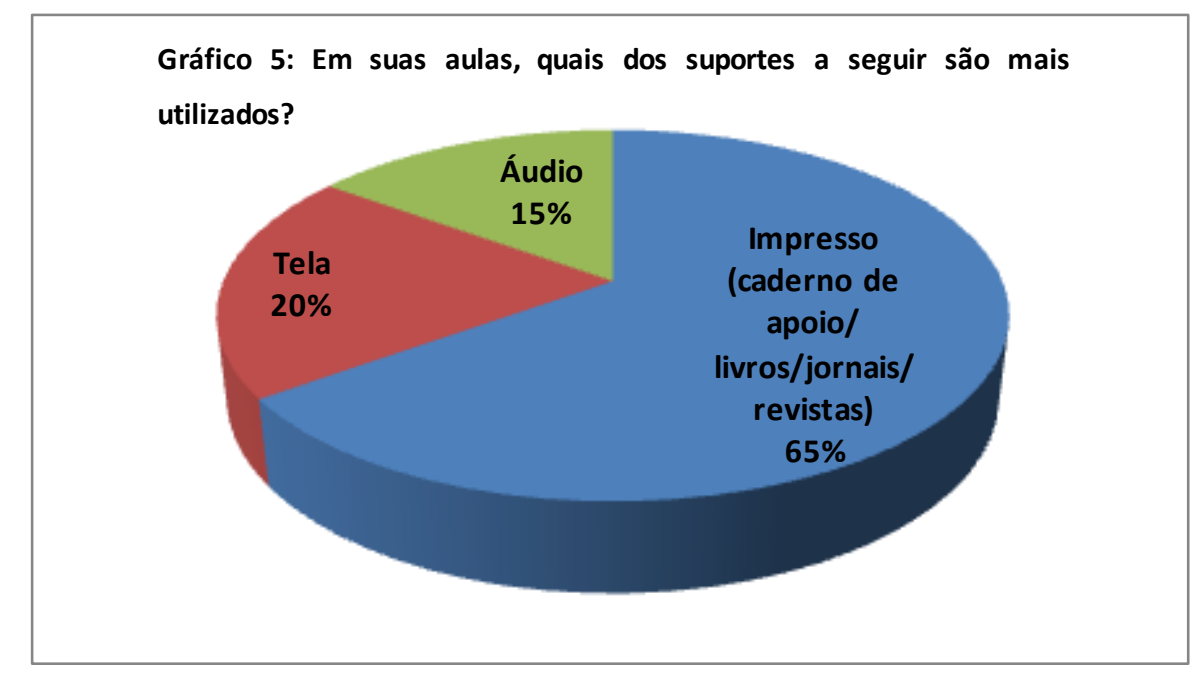




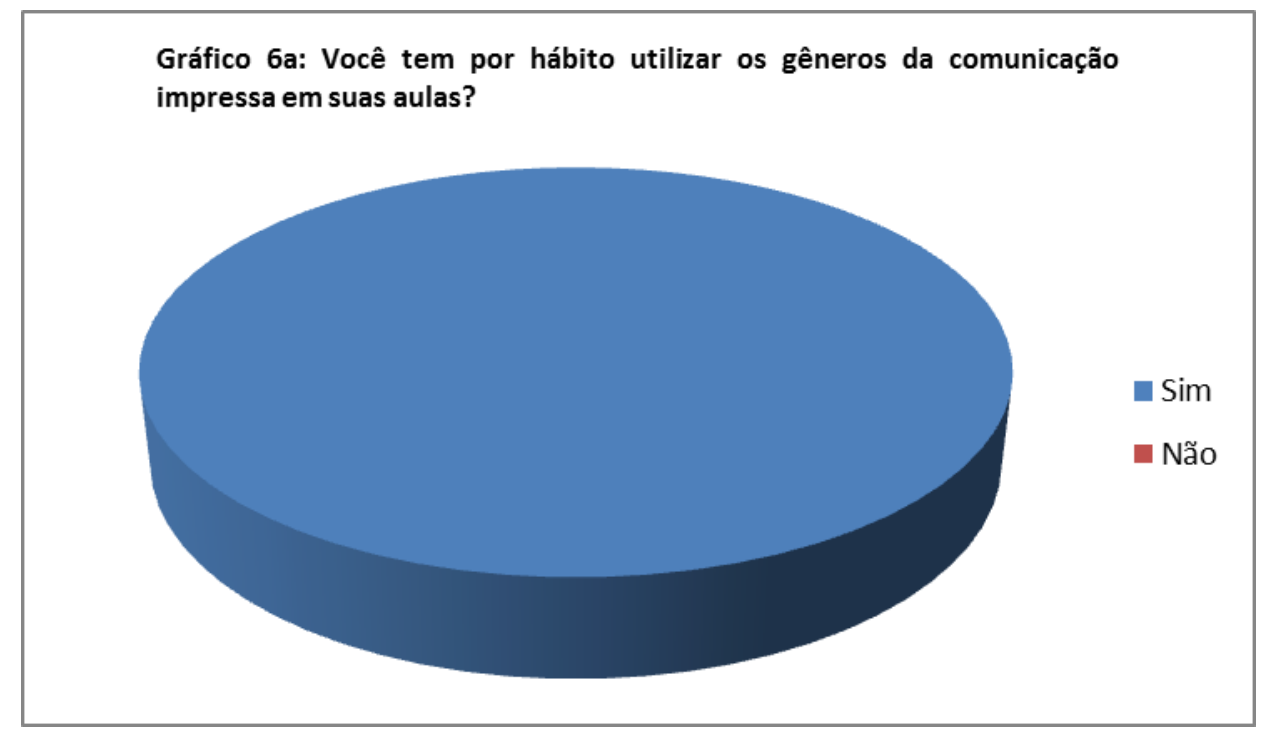

Gráfico $6 \mathrm{~b}$ : Em caso positivo, com que frequência?

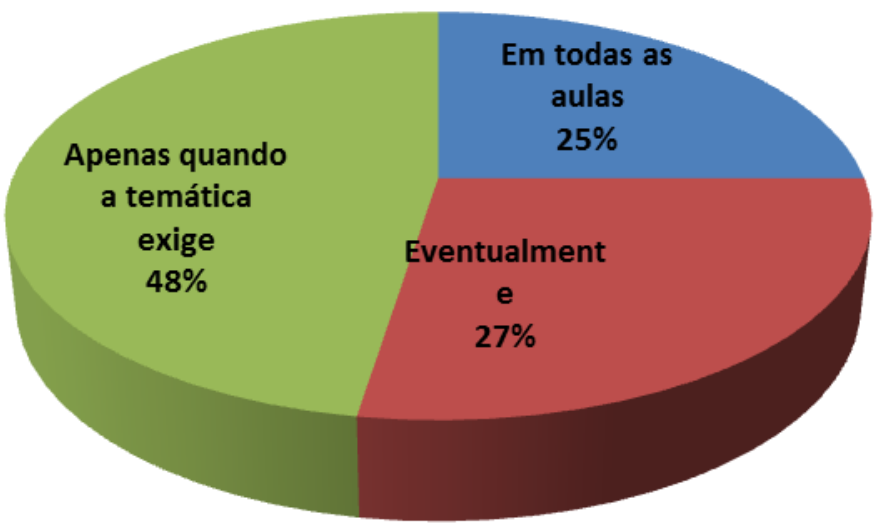

Nos gráficos $6(a ; b)$, após a mensuração, observamos que o primeiro aponta que $100 \%$ dos docentes usam com frequência os gêneros da comunicação impressa. O segundo questionamento é dúbio, já que a expressão "tem por hábito" sugere atividade diária. Porém, observamos nas respostas que $48 \%$ dos docentes disseram utilizar os gêneros do impresso "apenas quando a temática exige", $25 \%$ em todas as aulas (não desconsiderando o material pedagógico) e os outros $27 \%$ eventualmente.

A análise torna necessários alguns apontamentos: se os "cadernos de apoio" do município são o suporte mais utilizado por 65\% dos professores (gráfico 5), deduzimos, $a$ priori, que estes professores sentem-se na "obrigação", mesmo que indiretamente, de utilizálos, e não apenas quando uma temática requisita, afinal este material pedagógico é elaborado com base no plano de ensino anual da área. O fato será analisado com mais zelo nas entrevistas. 


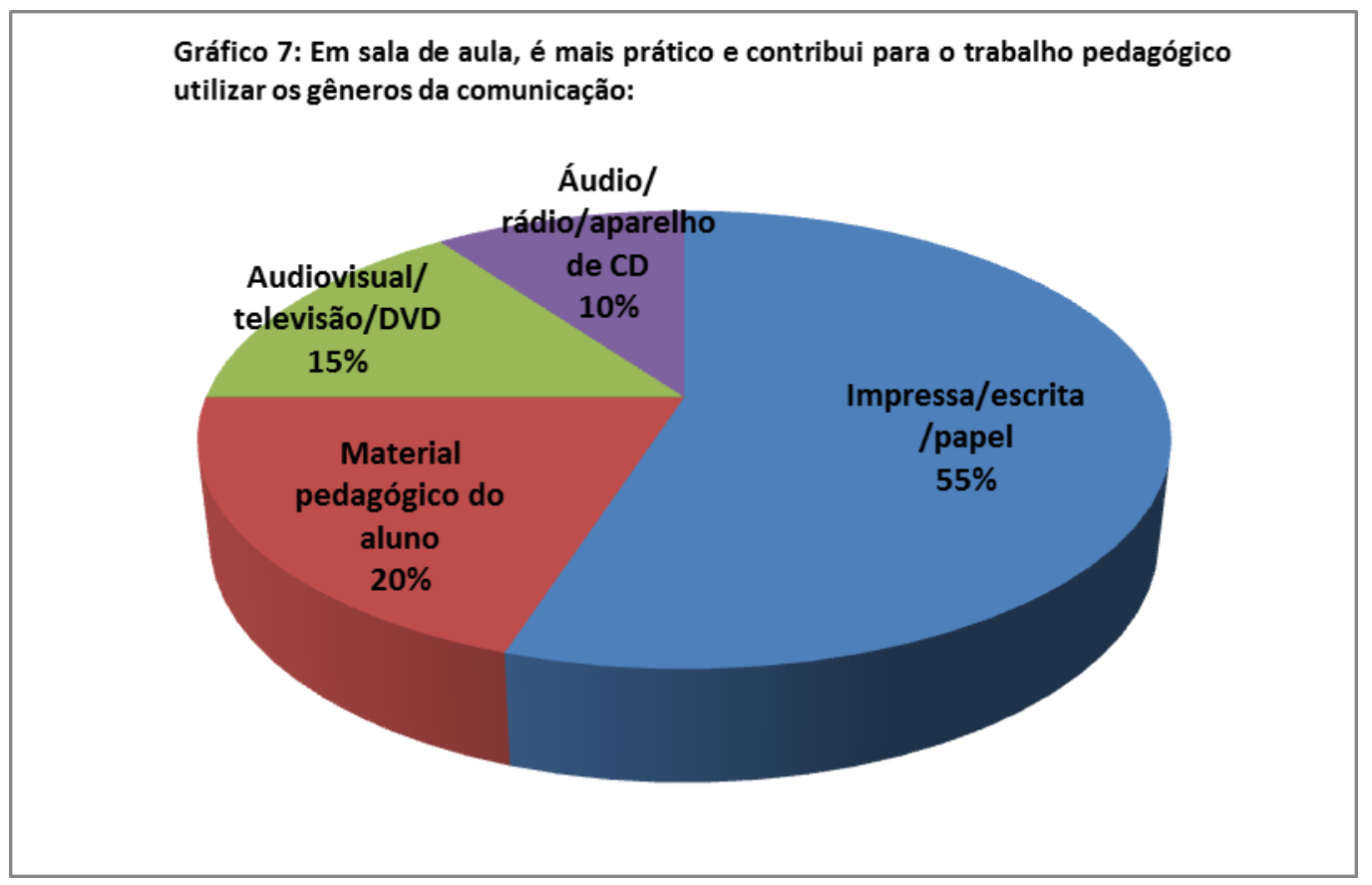

O gráfico 7 demonstra que as linguagens do suporte do impresso estão fortemente presentes em sala de aula: 55\% dos professores acreditam ser mais prático realizar atividades com estes gêneros na prática didática, dado que reforça a nossa hipótese de que a disciplina também colabora para esta preferência.

Nas entrevistas ficou evidenciado que o impresso é preferido pelos docentes para o uso e ações pedagógicas com os adolescentes. Embora admitam a necessidade de momentos com textos do mundo digital, ainda preferem um equilíbrio entre o uso do impresso e estes, mesmo quando a temática se relaciona às linguagens dos meios de comunicação.

A questão se modifica ao considerarmos que, na época da aplicação dos questionários, julho de 2011, 20\% dos docentes de Língua Portuguesa apontavam a praticidade do uso do material pedagógico impresso dos alunos no tratamento com os gêneros do jornalismo e da publicidade em sala de aula. $\mathrm{O}$ fator se torna conflituoso, pois desde meados do $2^{\circ}$ semestre de 2011 este material impresso não é mais disponibilizado aos alunos dos $8^{\circ}$ e $9^{\circ}$ anos $\left(7^{\mathrm{a}}\right.$ e $8^{\mathrm{a}}$ série) da rede municipal, cabendo ao professor valer-se de outros recursos e métodos em sua prática. Trataremos especificamente do material pedagógico no gráfico 13. 


\section{As linguagens (gêneros) do jornalismo e da publicidade (Gráficos 8 e 9)}

As respostas dos questionários quanto ao item direcionaram novas perguntas nas entrevistas neste contexto. Para tanto foi preciso analisar quais gêneros do jornalismo são mais utilizados se comparados aos publicitários, apresentados no gráfico 8.

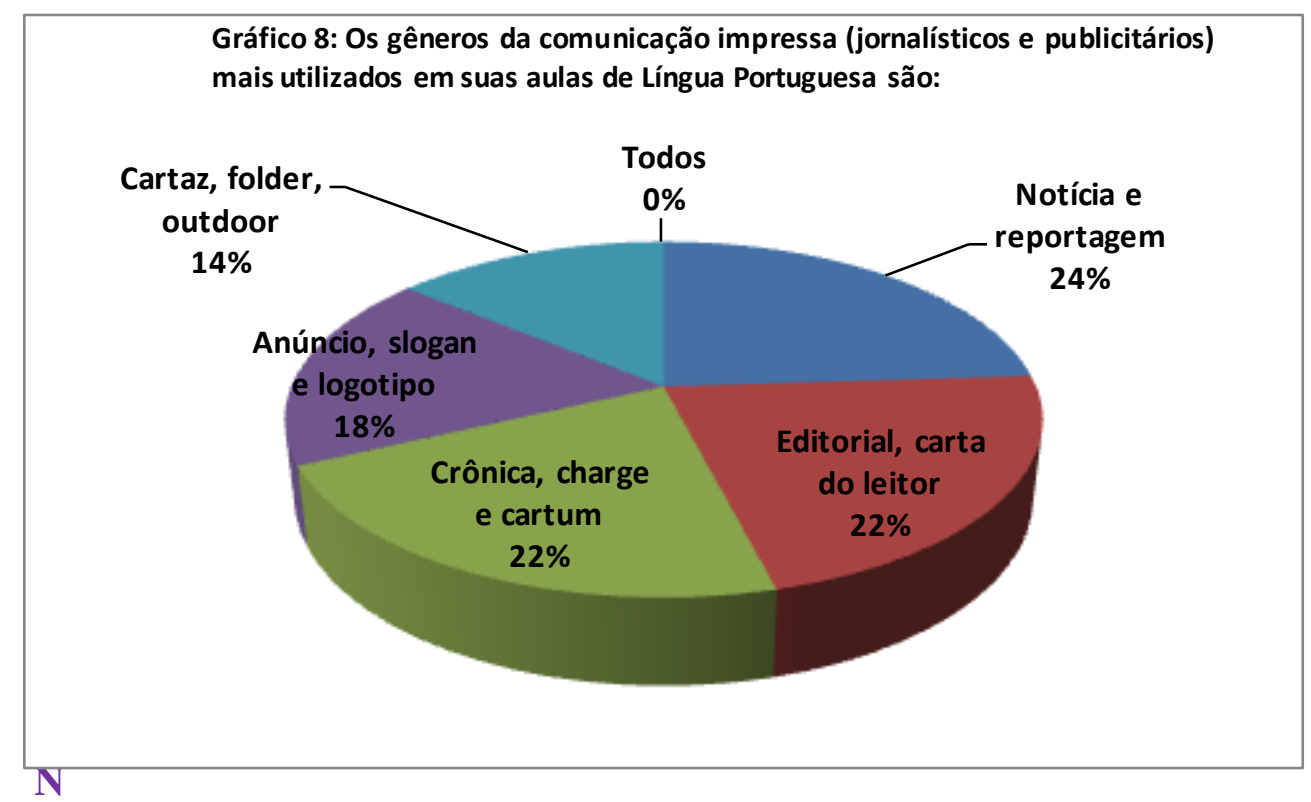

Os gêneros do jornalismo: notícia, reportagem, editorial e carta do leitor são preferidos, tanto para os professores do $8^{\circ}$ ano quanto para os do $9^{\circ}$ ano do Ensino Fundamental. Nesta amostragem apresentamos a somatória dos anos envolvidos.

A partir destes dados, apuramos também que tanto a linguagem como os textos jornalísticos são mais utilizados pelos docentes, embora a questão imagética junto aos adolescentes requeira dos professores o uso de imagens e mensagens que abordem estes recursos, tais como: charge, cartum, caricatura, bem como os publicitários.

No que diz respeito à linguagem publicitária, verificamos que gêneros como anúncio e folder, entre outros, são mais utilizados no $9^{\circ}$ ano, etapa em que o plano de ensino documentado contempla o uso dessa linguagem. 
Abaixo, o gráfico 9 revela que estes textos são muito utilizados para estudo da estrutura, conteúdo e suporte de texto (50\%) e também para provocação de comentários sobre determinada temática em sala (50\%).

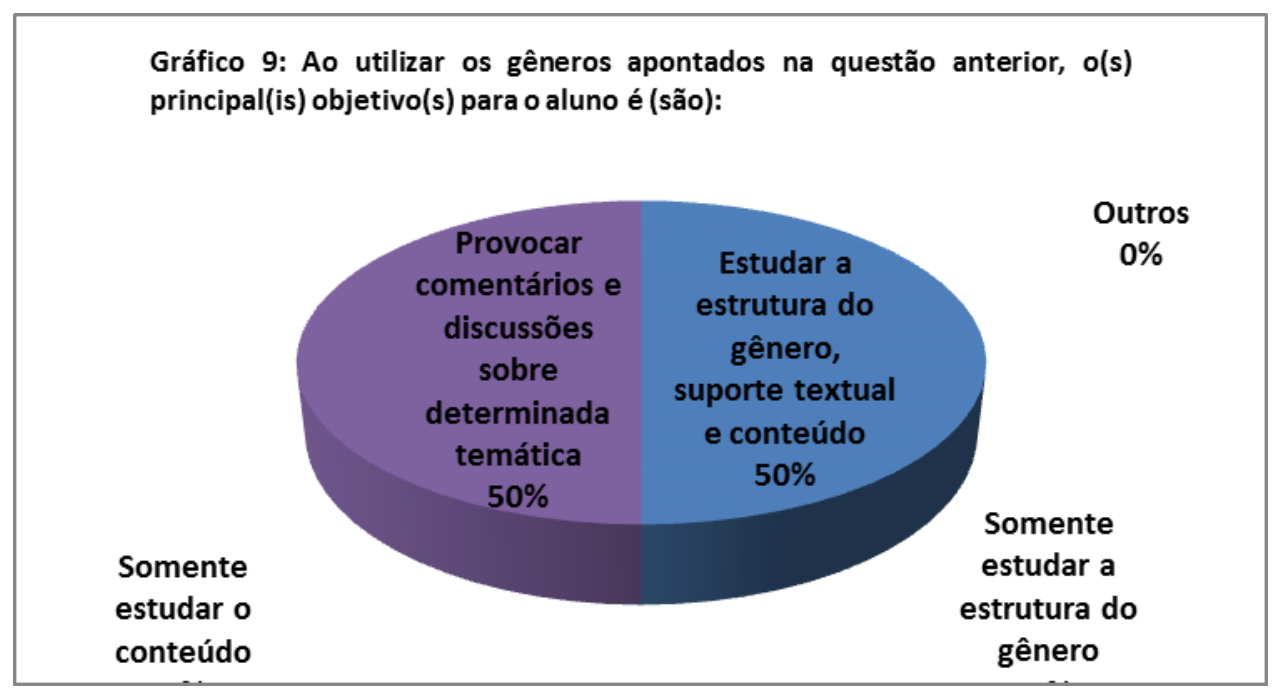

De acordo com os professores, a discussão da estrutura requer, primeiramente, uma motivação acerca da temática; por se tratar de público adolescente, os assuntos desses gêneros devem abarcar este universo e o jornalismo e a publicidade são colaborativos neste sentido, sobretudo quando inserem mensagens não verbais.

\section{O uso e a leitura de imagens (Gráficos 10 e 11)}

Gráfico 10: Você costuma trabalhar com a leitura de imagens em suas aulas?
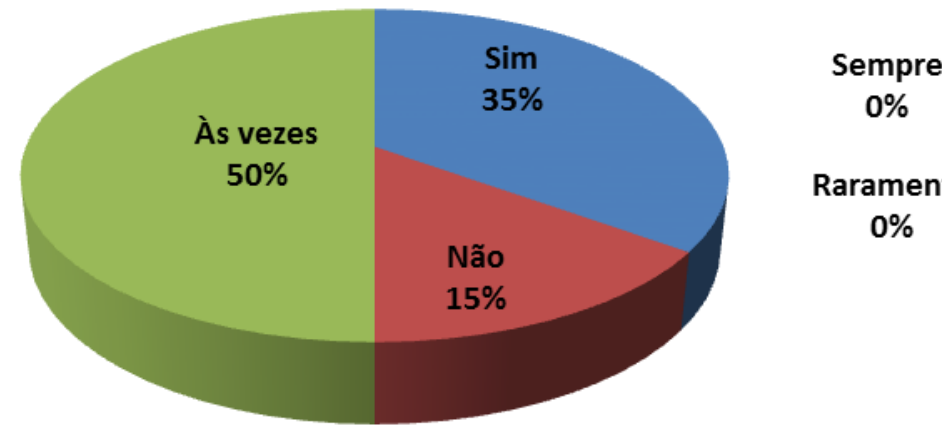

Raramente

$0 \%$

Cerca de 35\% dos docentes de Língua Portuguesa afirma usar recursos imagéticos em sala, contudo, $15 \%$ não os incluem em sua prática. Sendo assim, o gráfico 10 corrobora a 
assertiva de que, há professores resistentes a este estudo com os alunos, mesmo que estejam incluídos em atividades com outros gêneros que exijam este tipo de estudo, caso de alguns do jornalismo e a maioria dos publicitários.

Nas entrevistas, percebemos que as mensagens e símbolos (incluindo as imagens) são uma espécie de "requisito" para chamar a atenção dos alunos contemporâneos. Assim, por maiores que sejam as dificuldades encontradas, eles são cada vez mais introduzidos em sala de aula, principalmente com estes tipos de textos: anúncios, propaganda televisivas comerciais, charges, cartuns, caricaturas, reportagens etc.

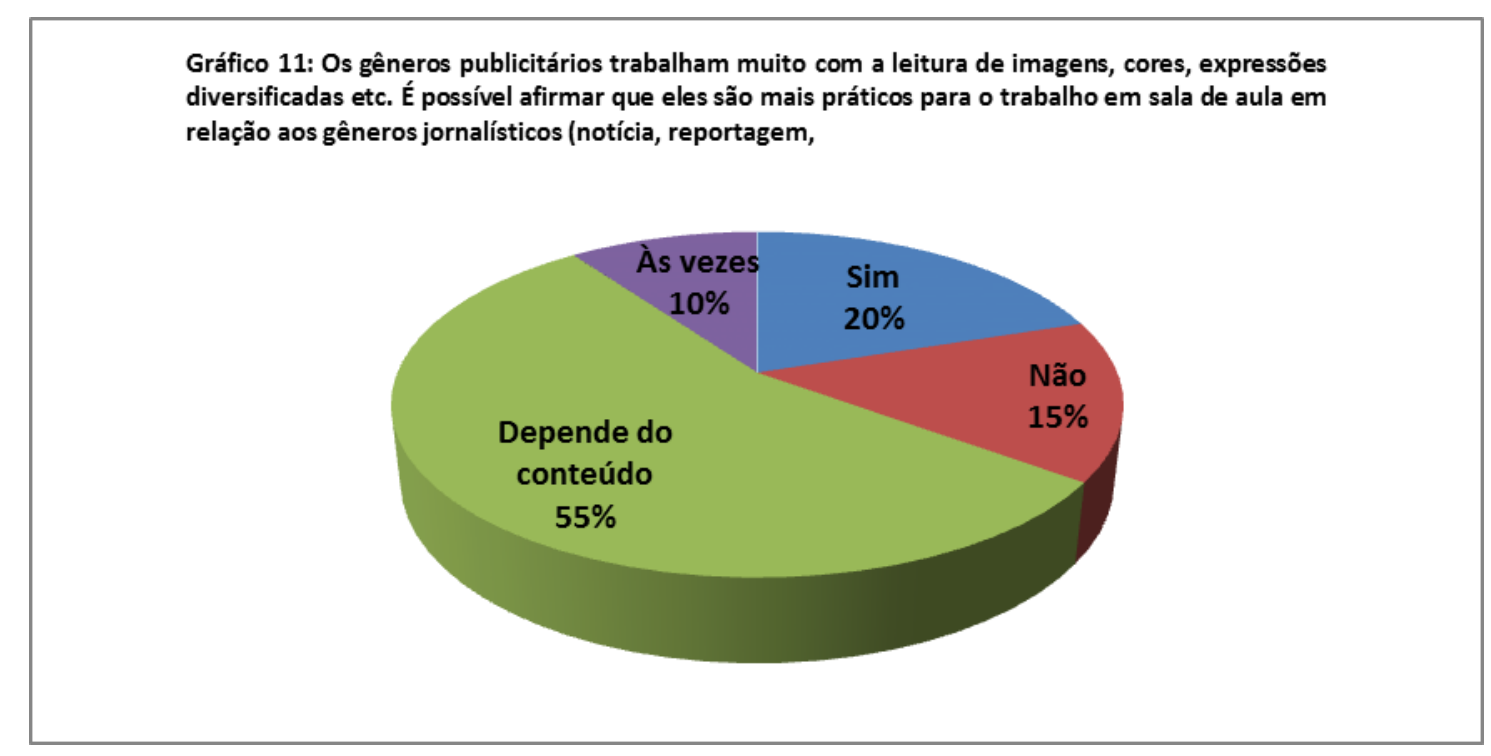

Quanto aos gêneros publicitários, de acordo com o gráfico 11, é fato sua aceitação pelos professores Porém, para 55\% deles a utilização depende do conteúdo a ser estudado. Diante deste fato, surgiu uma dúvida: a dependência é somente de conteúdo ou também de recursos e/ou metodologia?

O questionamento acima foi aprofundado na segunda fase da pesquisa. No papel de entrevistados, os professores se mostraram muito mais adeptos, hoje, aos referidos textos, por causa das necessidades da faixa etária dos alunos. Nesta etapa, mais à vontade, afirmaram se sentir "obrigados" a interagir com ações mais próximas dos adolescentes, em suas aulas, por isso optaram por linguagens com as quais estes alunos demonstram mais afinidade, tais como as midiáticas e digitais. 


\section{Outras linguagens}

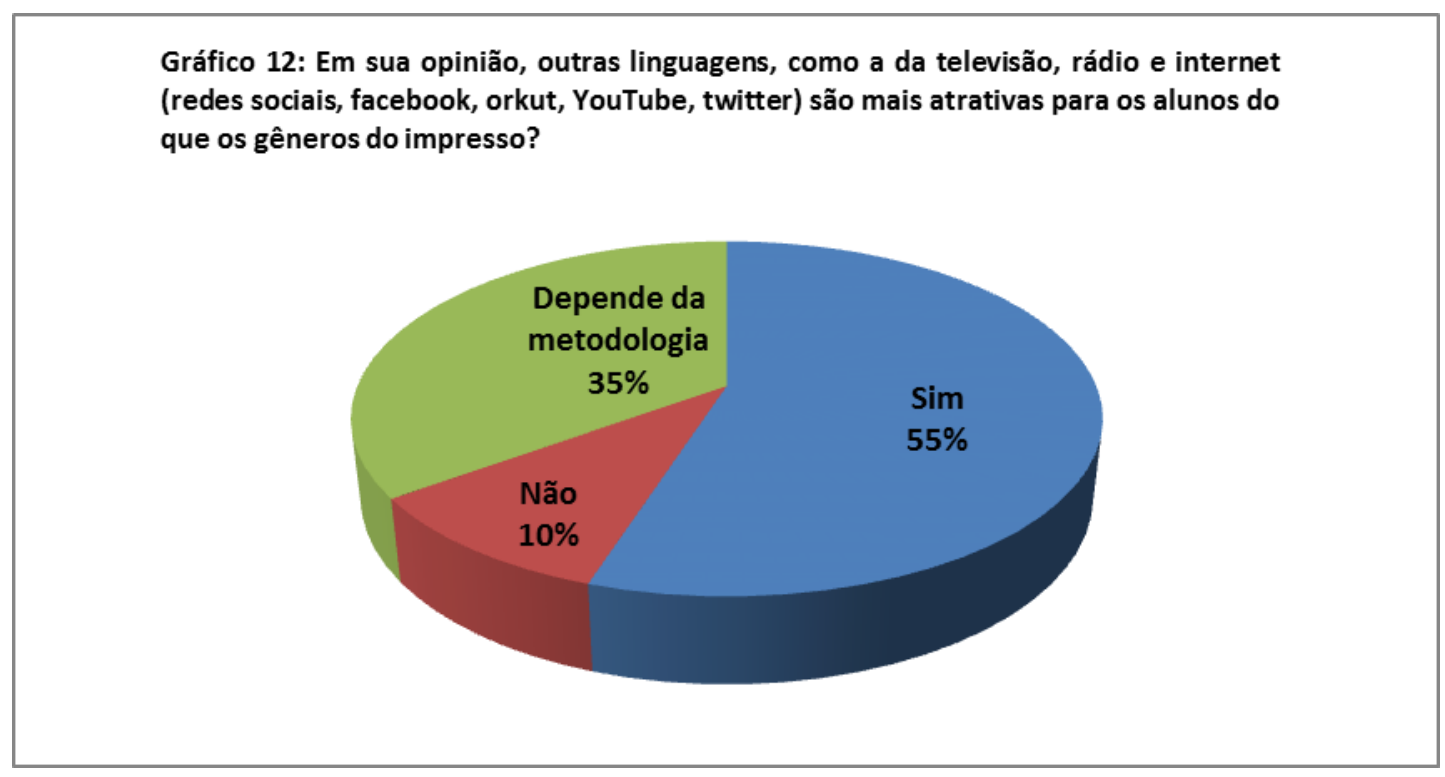

Quanto às linguagens e redes sociais digitais no âmbito da tradicional sala de aula, para 55\% dos docentes sem dúvida elas são mais atrativas do que os gêneros do impresso. Não obstante, para o mesmo número de pesquisados, como apontado no gráfico 7, é mais prático o uso destes textos comunicacionais em sala. Os dados constatam que o professor reconhece a preferência dos alunos, mas ainda mantém o fazer pedagógico centralizado na linguagem verbal.

\section{O material pedagógico (Gráfico 13)}

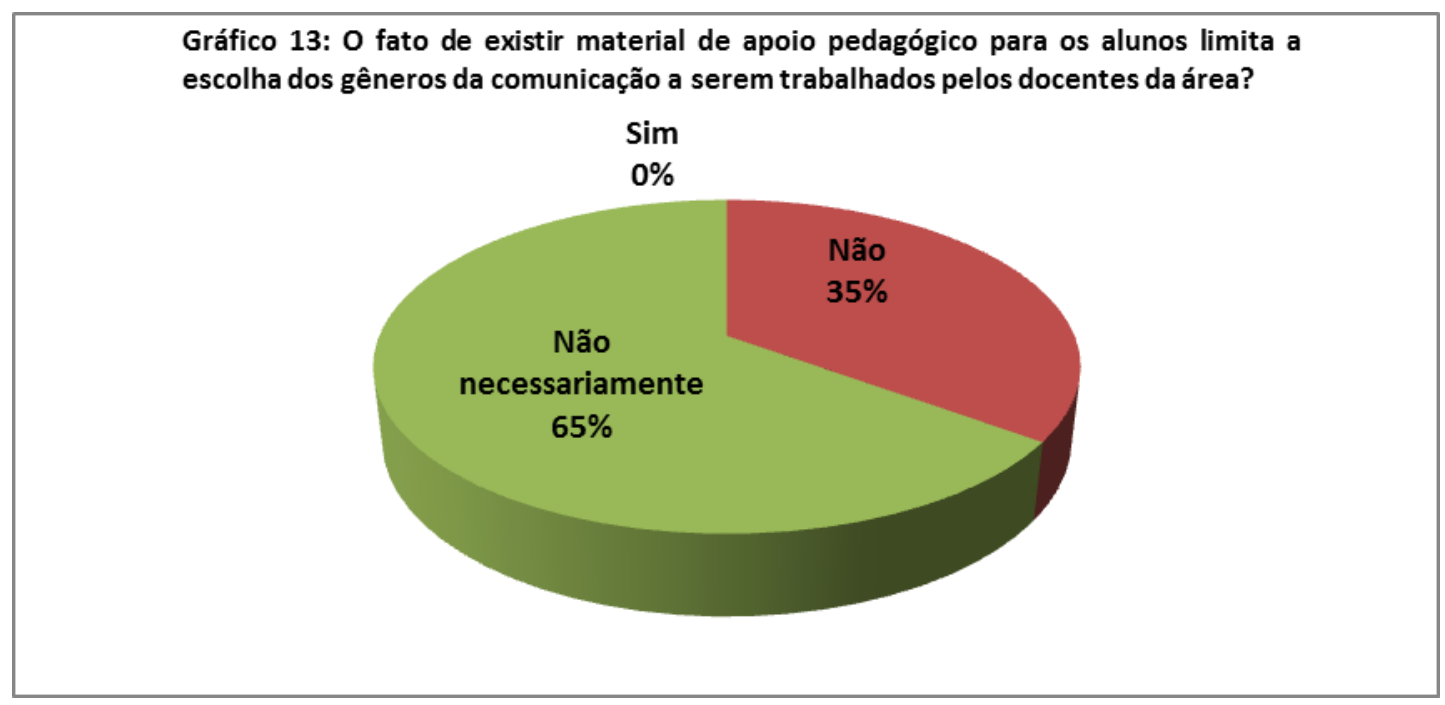


Os chamados cadernos de apoio pedagógico, que eram distribuídos aos alunos da rede municipal, não circulam mais no impresso desde o segundo semestre de 2011, por causa de problemas contratuais. A princípio foram retirados de circulação apenas os cadernos dos anos finais com a justificativa da migração para o universo digital. Conteúdo, no primeiro semestre de 2012 não circularam para todo o Ensino Fundamental. A alternativa disponibilizada pelo município foi a liberação dos cadernos para download, recurso que, segundo os docentes, não trouxe a comodidade e facilidade esperadas, afinal, apenas o professor acaba tendo a cópia do material e os alunos ficam sem a referência impressa, o que prejudica a ação pedagógica, sobretudo com os textos imagéticos. .

$\mathrm{Na}$ conversa com a pesquisadora, eles revelaram sentir muita falta do material, dificuldade que os levou a buscarem alternativas, como o maior uso do aparelho de data show e outros recursos.

$\mathrm{Na}$ visão dos pesquisados, os gêneros comunicacionais elencados no planejamento e, consequentemente, inseridos no conteúdo por conta de imagens e ícones, foram os que tiveram o uso mais prejudicado, tais como charge, cartum, caricatura, reportagens etc.

\section{O Plano de Ensino de LP (Gráficos 14 e 15)}

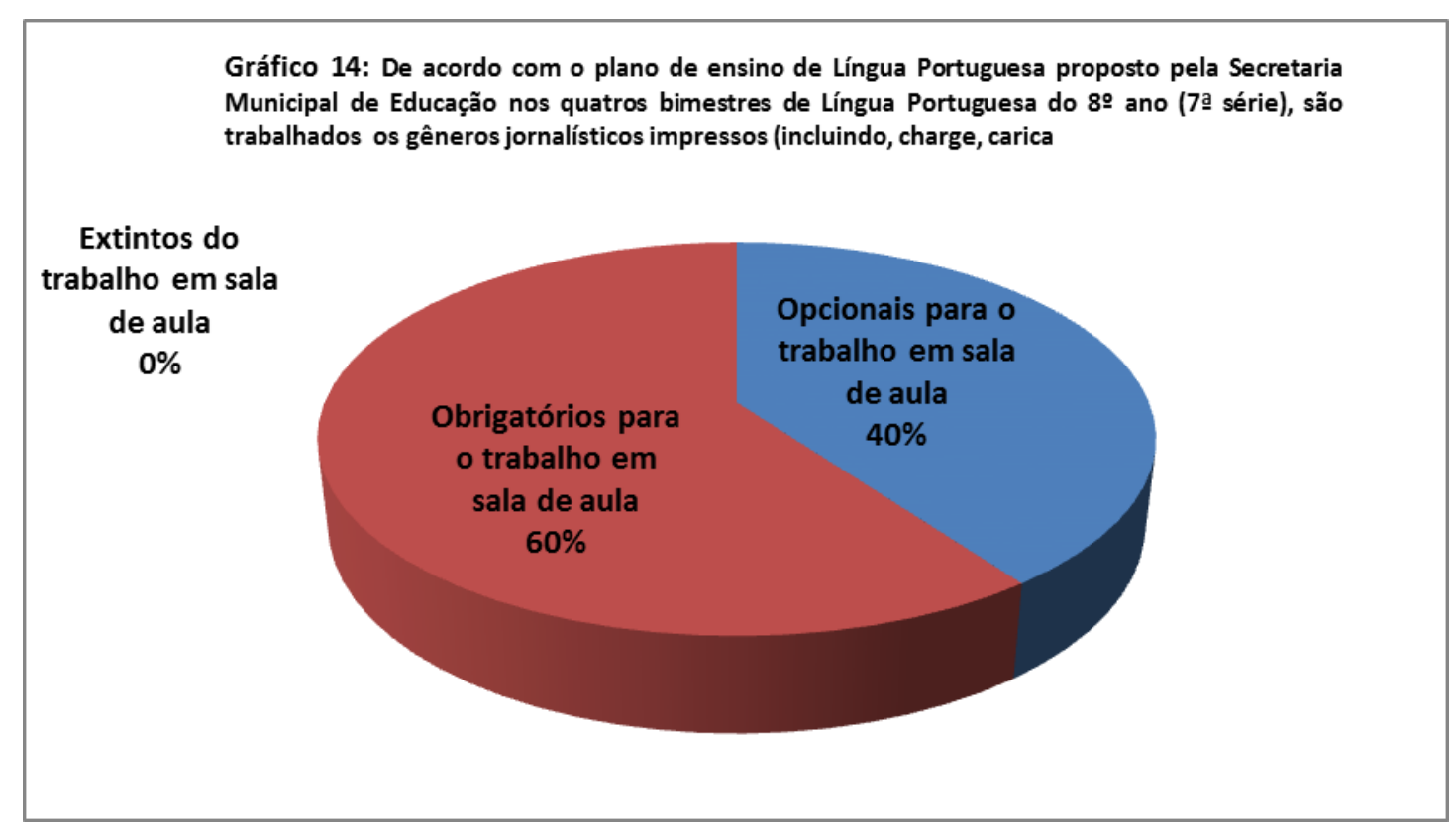

O gráfico 14 apresenta o questionamento dos docentes quanto à opção ou obrigatoriedade dos gêneros do jornalismo e publicidade no plano de ensino de Língua Portuguesa nos anos finais do Ensino Fundamental. 
Nos questionários, $60 \%$ dos docentes pesquisados apontaram que os textos da comunicação devem, obrigatoriamente, ser trabalhados no Ensino Fundamental. Um número significativo, cerca de $40 \%$, respondeu que poderiam ser opcionais. Vale ressaltar que esta pergunta contém uma informação equivocada, pois os gêneros jornalísticos também possuem estrutura narrativa, não apenas o romance e o conto, como afirmado na questão. Os docentes revelaram que estes tipos de textos são fundamentais para o trabalho com os adolescentes.

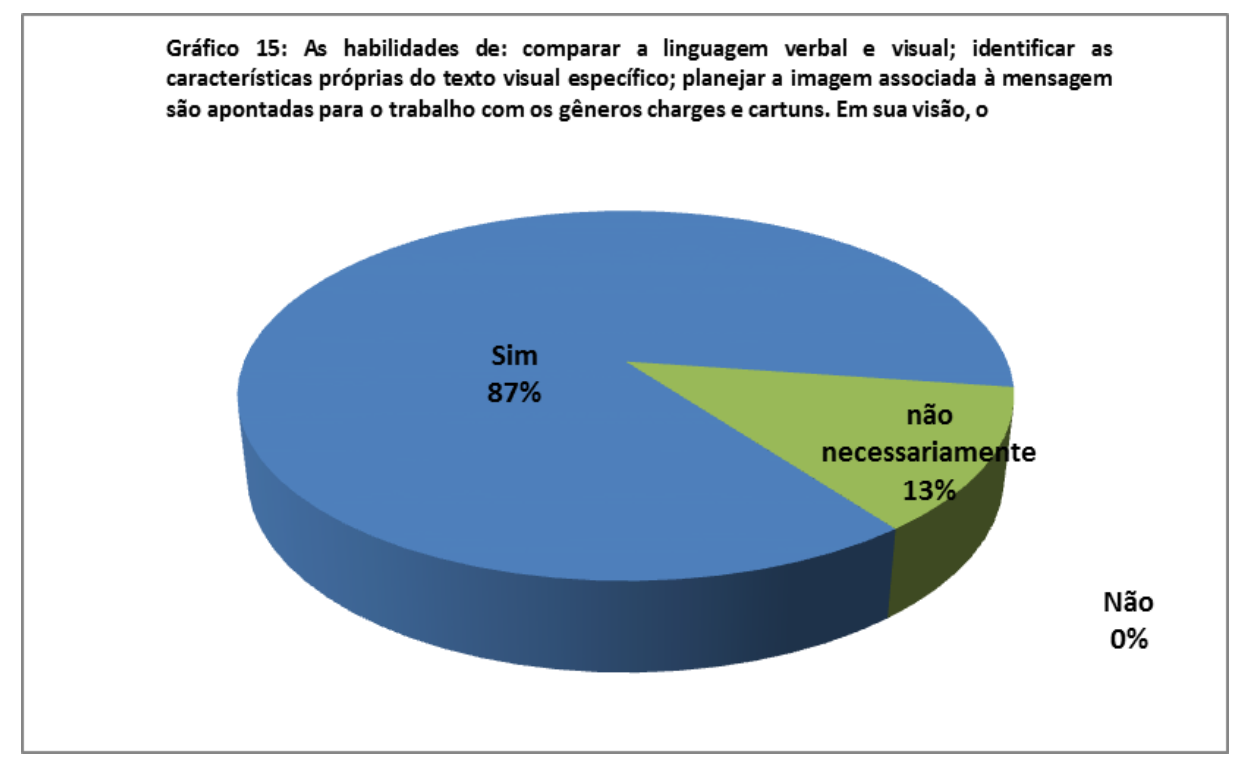

Algumas habilidades elencadas no planejamento pareceram desconhecidas da leitura dos docentes, mas inseridas na prática em sala de aula, demonstrada no gráfico 15. $\mathrm{O}$ questionamento refere-se se as habilidades no trabalho com charges e cartuns, na visão dos docentes, poderiam ser acrescidas no $9^{\circ}$ ano no tratamento dos textos publicitários.

\section{Leitura, Educomunicação e gêneros do jornalismo e publicidade (Gráficos 16, 17 e 18)}

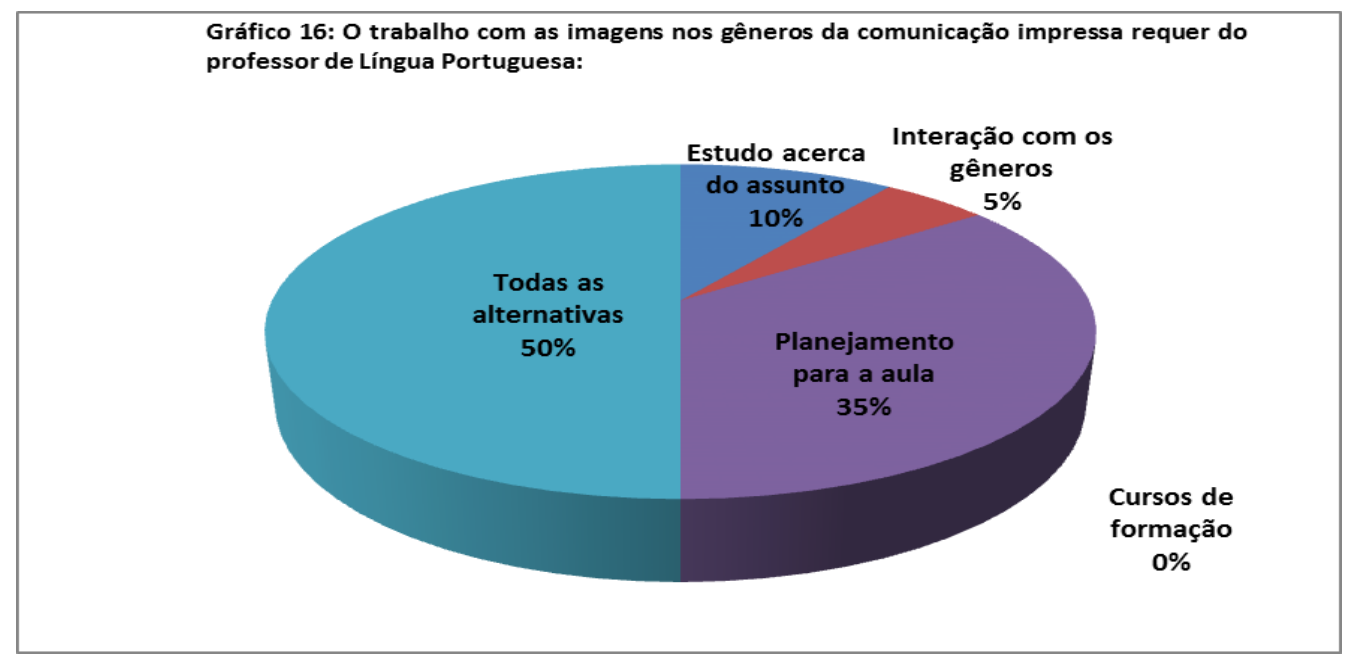


O gráfico 16 demonstra que o professor (35\%) considera necessário "planejar" suas aulas para o uso da imagem. Acreditamos que este ato esteja diretamente ligado a um estudo maior do assunto. Outro número revelador diz respeito aos cursos de formação continuada - é unanimidade o fato de serem desnecessários para o trabalho com as linguagens da comunicação.

Sendo assim, incluímos esta questão no roteiro de entrevistas e constatamos, a necessidade do professor de receber mais orientações quanto à linguagem digital nos cursos do Centro de Aperfeiçoamento de Professores. Em relação aos encontros do CAP, eles são divididos entre os chamados docentes polivalentes (PEB I), responsáveis pelo ensino do $1^{\circ}$ ao $5^{\circ}$ ano, e os especialistas de área (PEB II), que lecionam do $6^{\circ}$ ao $9^{\circ}$ ano do Ensino Fundamental. Os primeiros se reúnem em um auditório onde um professor/formador apresenta assuntos relacionados às dificuldades de aprendizagens nos anos iniciais, enquanto os demais, de acordo com a disciplina, ficam em salas com educadores das próprias áreas.

A abordagem de aspectos referentes à interface comunicação e educação e ações pedagógicas na sala de aula relativas ao campo midiático e linguagens é constantemente solicitada pelos pesquisados.

\section{A Educomunicação}

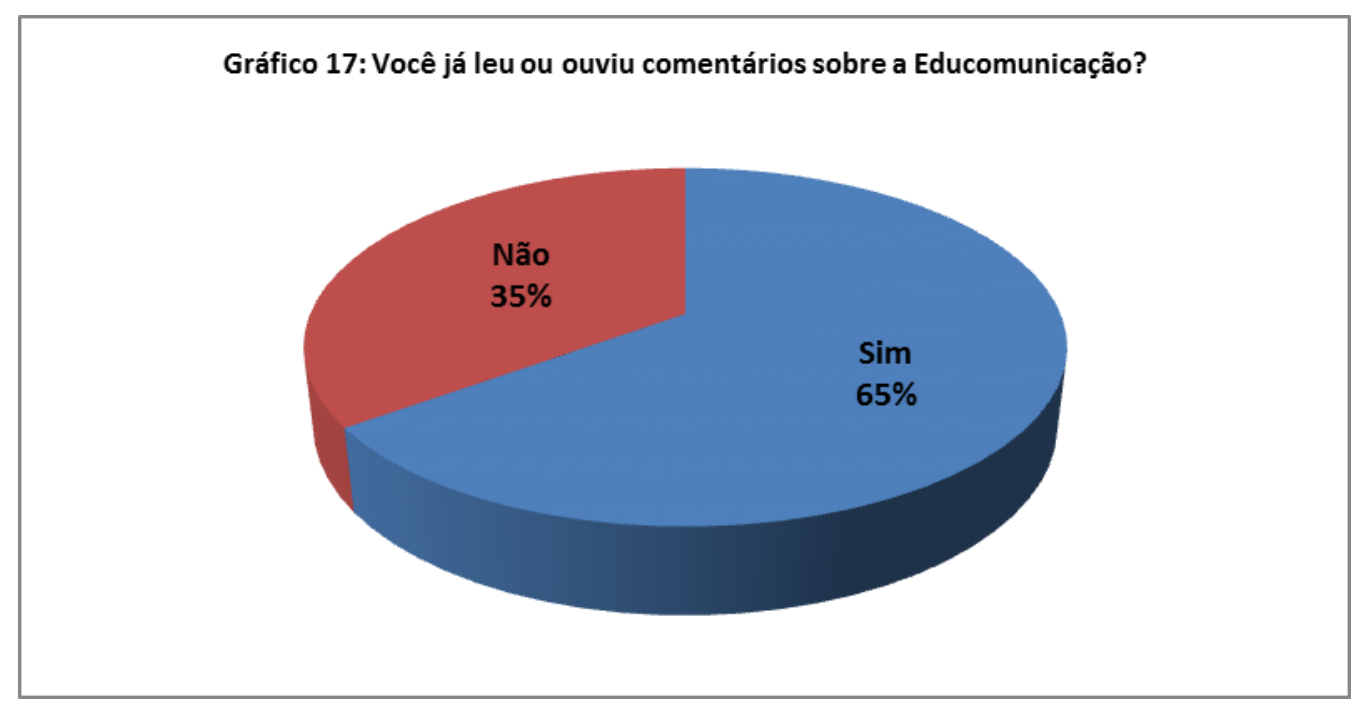

A Educomunicação não é um assunto totalmente desconhecido pelos professores de Língua Portuguesa, pois na própria proposta curricular o termo é citado, ainda que superficialmente. A ideia do trabalho com os meios comunicacionais não é novidade para os professores; nos diálogos com a pesquisadora, eles revelaram, hoje, ser um processo cada vez 
mais natural e incorporado ao ambiente educacional dos adolescentes, cabendo aos professores se atualizarem da melhor forma possível sobre as linguagens e ações didáticas das mensagens midiáticas.

\section{Os gêneros do jornalismo e publicidade}

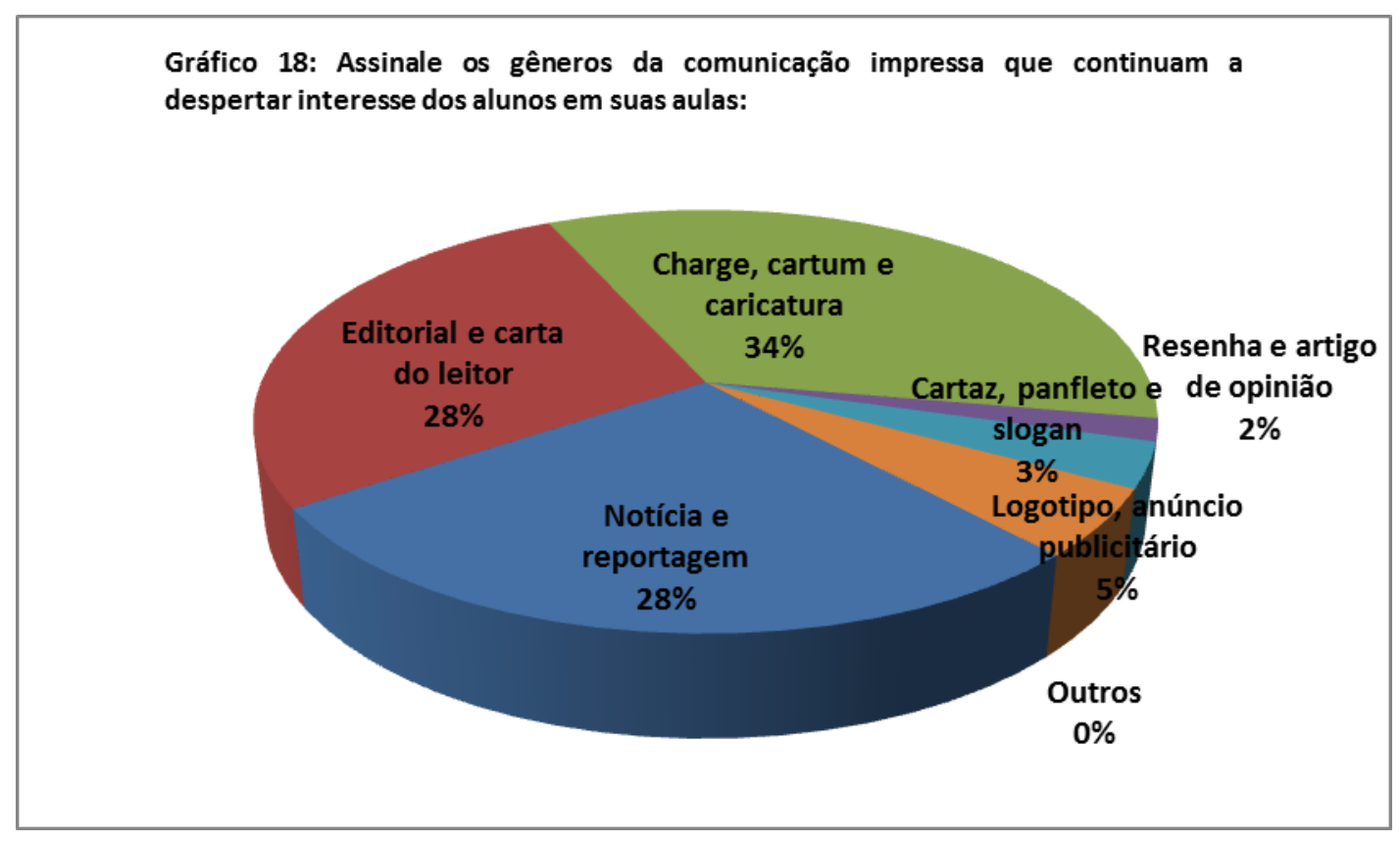

Entendemos que a questão do gráfico 18 é muito importante, uma referência para o aprofundamento da pesquisa, por estar diretamente relacionada ao nosso objeto. Na visão docente, revelado nas entrevistas a serem apresentadas, é bastante presente a ideia de atrair o interesse do público adolescente, sobretudo por meio de gêneros como cartuns e charges, ou seja, linguagem não verbal. Entretanto, nos questionários estes textos não foram os mais indicados pelos professores como os mais utilizados em sala. Adiantamos que, nas entrevistas, a situação sofreu alterações, pois os pesquisados relataram diversas práticas nas quais os próprios alunos reivindicam atividades com mensagens imagéticas.

\section{Considerações sobre a análise descritiva}

$\mathrm{Na}$ primeira etapa da pesquisa empírica, consideramos a amostra probabilística por meio de dados indicativos percentuais, com vistas a garantir um levantamento acerca do contexto educacional, ações didáticas dos professores de Língua Portuguesa e recursos disponibilizados pelo município de Barueri, fatores capazes de interferir no uso das linguagens da comunicação em sala de aula. 
A tabulação foi dividida em temáticas, o que possibilitou o aprofundamento das respostas e elaboração de novas questões direcionadoras ao roteiro de entrevistas.

Neste momento, de acordo com a organização dos dados, foram verificados oito tópicos: 1) Equipamentos audiovisuais e tecnológicos; 2) Suportes textuais em sala de aula; 3) As linguagens jornalísticas e publicitárias; 4) O uso e a leitura de imagens; 5) Outras linguagens; 6) Material pedagógico; 7) O plano de ensino de Língua Portuguesa; 8) Leitura, educomunicação e gêneros do jornalismo e publicidade.

Em relação aos aparatos e recursos de tecnologia das 14 unidades escolares pesquisadas, constatamos que os aparelhos (televisão, rádio, DVD, câmera digital e até o extinto videocassete) existem. Não foram mensuradas as condições de uso, conservação e quantidades, entretanto, infraestrtura e currículo, caso das escolas integrais, contribuem para a utilização e presença física dos equipamentos. Tais instituições possuem um currículo próprio (ver anexo $C$ ) e diferenciado em relação à disciplina de Língua Portuguesa, com duas aulas a mais que outras do município - são direcionadas, exclusivamente, para orientação de leitura (OLP).

O item mais relevante desse item se refere à inserção gradual do aparelho data show nas práticas didáticas, devido às exigências do público de adolescentes necessitados de mais atrativos para participação nas aulas.

Ainda sobre o tema, destacamos que $10 \%$ dos docentes apontaram a inexistência de laboratórios de informática nas escolas. Soubemos, posteriormente, que no $2^{\circ}$ semestre de 2011 foram feitas reformas para implantação de espaços para esta atividade e/ou da internet, no caso das unidades que já possuíam o laboratório.

A discussão elencada perpassa inúmeros aspectos e não se restringe apenas à estrutura física e elaboração de atividades de uma àrea específica, pois os princípios metodológicos e o planejamento interferem sobremaneira nas ações docentes, mesmo nas unidades escolares que possuem professores (instrutores) de informática para lecionar neste espaço. Sob este enfoque, ressaltamos o empate técnico entre as atividades realizadas por meio da digitação e as manuscritas, esta últimas solicitadas como tentativa dos docentes de evitar possíveis plágios por parte dos adolescentes.

Apesar dos meios audiovisuais e tecnológicos despertarem o interesse nas práticas pedagógicas com as novas gerações, os professores evidenciaram, tanto nesta como na próxima fase da pesquisa, o material impresso como suporte hegemônico nas escolas.

No primeiro período de coleta de dados, os docentes ainda tinham à disposição o caderno pedagógico distribuído para toda a rede municipal. Entretanto, com a saída de 
circulação deste material, no $2^{\circ}$ semestre de 2011, os educadores de Língua Portuguesa dos anos finais ( $8^{\circ}$ e $9^{\circ}$ anos) viram-se "obrigados" a modificar a apresentação dos conteúdos em sala de aula, buscando em equipamentos como o data show possibilidades de mantê-los, sem alteração drástica, de acordo com o plano de ensino da área na rede educacional.

Nas observações destes professores, percebemos que muitos alegam, apesar das faixas etárias dos alunos, a necessidade de atividades "concretas", ou seja, do manuseio de jornais e revistas para localização, análise de estrutura e temática das mensagens a serem estudadas in loco. Sendo assim, apesar do amplo universo digital, eles ressaltam a busca pelo equilíbrio. Na visão deles, por exemplo: se o gênero é o editorial, é válido oferecer jornal impresso para a localização dos alunos, para que haja uma familiarização anterior ao processo de investigação na internet.

A notícia e a crônica foram as mais citadas na ação didática dos educadores quanto à linguagem jornalística. Em relação aos gêneros publicitários, o folder, slogan, marcas e campanhas publicitárias, por se valerem de imagens, são mais significativos na opinião de $60 \%$ dos pesquisados.

No plano de ensino da referida disciplina para o $9^{\circ}$ ano do Ensino Fundamental, está especificado um conjunto de habilidades com textos imagéticos junto aos discentes, tais como: a habilidade de estabelecer relação entre texto, contexto e suporte, o escrito (verbal) e os recursos gráficos (visuais), de reconhecer a intencionalidade de autoria, de analisar criticamente os contéudos das mensagens e as conotações que estas veiculam.

De acordo com as informações, houve a reafirmação de que o uso e a leitura de símbolos são interdependentes das atividades estudadas e que as redes sociais e os mensageiros instantâneos (facebook, orkut, twitter, $M S N$ ) e também meios como a televisão são mais atrativos. Contudo, os professores lembram que os textos comunicacionais, jornalísticos e publicitários, mesmo que impressos, são os que mais se aproximam da realidade atual dos alunos de 13 a 16 anos em sala de aula.

Em relação ao planejamento anual de Língua Portuguesa, especialmente no caso do $8^{\circ}$ ano ( $7^{\text {a }}$ série), são elecandos, durante todo o ano letivo, os seguintes gêneros: no primeiro bimestre - notícia, entrevistas, reportagens, gráficos e tabelas; no segundo - editorial e a carta do leitor (argumentativa); no terceiro - crônica, sinopse e resenha de filmes; no quarto cartum, charge, biografia e caricatura.

Segundo o referido plano, o jornalismo é o foco da disciplina nesta fase de ensino e não há espaço para os textos publicitários. Percebemos que esta preferência, na rede educacional, influencia a opinião dos educadores na escolha de tais textos. Já os referentes ao 
mundo da publicidade aparecem mais no $9^{\circ}$ ano ( $8^{\mathrm{a}}$ série), último do Ensino Fundamental, possivelmente porque o documento determina o trabalho com esta linguagem nos meses de maio e junho. Nas entrevistas, os educadores conseguem expor com mais profundidade as diferenças entre tais propostas, entretanto defendem que ambas são necessárias.

Quanto aos cursos de formação continuada no Centro de Aperfeiçoamento de Professores (CAP), a escolha dos temas são baseadas nas avaliações externas municipais e nas necessidades verificadas pela Coordenação do Ensino Fundamental em conjunto com o Secretário de Educação. Ressaltamos que várias alterações dos cronogramas de cursos ocorreram em função de solicitações dos próprios educadores do município.

Com relação à educomunicação, o conceito em si é desconhecido da grande maioria dos professores, porém as ações didáticas que tratam desta interface entre Comunicação e Educação são evidenciadas pelos próprios docentes nos questionários e, principalmente, nas entrevistas. 


\section{A INTERPRETAÇÃO DOS DADOS}

Esta é a etapa em que é realizada a chamada teorização dos dados empíricos, de acordo com a proposta metodológica adotada neste trabalho.

Maria Immacolata Vassallo de Lopes lembra que "a explicação ou interpretação é a segunda etapa da análise e é com ela que a pesquisa atinge a condição própria da cientificidade" (2005:151). Sobre os métodos, a autora destaca que devem ser fornecidos pelo quadro teórico de referência, assim os resultados são integrados numa totalidade que confere tanto o objeto empírico como o teórico.

Em relação a este tipo de análise, três observações se fazem necessárias: a primeira diz respeito ao objetivo de cada etapa, portanto, é preciso verificar se ele foi atingido; a segunda diz respeito ao estabelecimento da diferença entre levantamento ou sondagem (survey) e pesquisa social, sendo esta última o tipo indicado para o campo da Comunicação; a terceira se refere à possível dicotomia entre análise qualitativa e quantitativa, o que não deve ocorrer (LOPES, 2005:152-153).

Assim, com base no modelo proposto pela autora, realizamos a interpretação das informações, previamente organizadas, de forma atrelada às referências teóricas apresentadas para que as futuras conclusões tenham o embasamento necessário.

É neste processo interpretativo que as hipóteses são testadas, confirmadas ou rejeitadas (total ou parcialmente). Teremos, então, condições de avaliar se: na prática pedagógica, o professor de Língua Portuguesa, por dificuldades de infraestrutura e/ou acesso, limita o uso das linguagens do jornalismo e da publicidade somente ao suporte do impresso; o professor considera o perfil dos alunos adolescentes e percebe que as novas tecnologias e linguagens interferem na recepção das mensagens e na constituição de sentidos; os gêneros do jornalismo e da publicidade, no suporte do impresso, prevalecem nas aulas dos docentes da referida área, devido à necessidade de aquisição da competência leitora e escritora pelos alunos.

Em síntese, somos conscientes da importância desta fase, pois assim alcançaremos um patamar que permitirá atingir "organicamente teoria e pesquisa, operações técnicas, metodológicas, teóricas e epistemológicas, numa única experiência de investigação" (LOPES, 2005:152). 


\section{Tabela-síntese dos questionários Análise quantitativa (\%) das respostas dos docentes}

\begin{tabular}{|c|c|}
\hline $\begin{array}{l}\text { 1) A escola onde que você trabalha possui equipamentos audiovisuais? } \\
\text { Assinale quais. A televisão foi assinalada pela maioria. }\end{array}$ & $18 \%$ \\
\hline $\begin{array}{l}\text { 2) A sua escola possui computadores, com ou sem internet, e laboratório de } \\
\text { informática? A maioria assinalou ter computadores, sem internet, sem } \\
\text { especificar o local de uso. }\end{array}$ & $55 \%$ \\
\hline 3) Os alunos usam computador na escola? Sim, responderam. & $61 \%$ \\
\hline 4) Os t & $\mathbf{5 0 \%}$ \\
\hline 5) Os suportes textuais mais usados em sala são os impres & $65 \%$ \\
\hline 6) a) Usam os gêneros da comunicação impressos. & $100 \%$ \\
\hline b) Apenas quando a temática exige. & $48 \%$ \\
\hline 7) É mais prático o uso em sala de aula dos textos da comunicação imp & $55 \%$ \\
\hline $\begin{array}{l}\text { 8) Notícia e Reportagem são os textos comunicacionais mais usados na } \\
\text { disciplina de Língua Portuguesa. }\end{array}$ & $24 \%$ \\
\hline $\begin{array}{l}\text { 9) O estudo da estrutura do gênero, conteúdo, suporte e o despertar de } \\
\text { comentários são os principais objetivos do uso dos gêneros do jornalismo e da } \\
\text { publicidade. }\end{array}$ & $\mathbf{5 0 \%}$ \\
\hline $\begin{array}{l}\text { 10) Você desenvolve atividades com leitura de imagens em sala de aula? Sim, } \\
\text { às vezes. }\end{array}$ & $50 \%$ \\
\hline $\begin{array}{l}\text { 11) Os gêneros publicitários são mais práticos que os jornalísticos nas } \\
\text { atividades em sala de aula? Sim, depende do conteúdo. }\end{array}$ & $55 \%$ \\
\hline $\begin{array}{l}\text { 12) Em sua opinião, outras linguagens, como a da televisão, rádio e internet } \\
\text { (redes sociais, facebook, twitter etc.) são mais atrativas aos alunos? Sim. }\end{array}$ & $55 \%$ \\
\hline $\begin{array}{l}\text { 13) O fato de existir material de apoio pedagógico limita as escolhas dos } \\
\text { gêneros comunicacionais a serem utilizados? Sim. }\end{array}$ & $65 \%$ \\
\hline $\begin{array}{l}\text { 14) Os textos do jornalismo e da publicidade deveriam ser obrigatórios para o } \\
\text { trabalho em sala? Sim. }\end{array}$ & $60 \%$ \\
\hline $\begin{array}{l}\text { 15) Várias habilidades presentes nos gêneros cartum, charge e caricatura } \\
\text { (inseridos no plano de ensino de Língua Portuguesa) deveriam ser aplicadas } \\
\text { também aos textos publicitários? Sim. }\end{array}$ & $87 \%$ \\
\hline $\begin{array}{l}\text { 16) O trabalho com os gêneros da comunicação impressa (jornalismo e } \\
\text { publicidade) requer do professor de Língua Portuguesa: estudo, planejamento } \\
\text { de aula e interação com os textos. }\end{array}$ & $50 \%$ \\
\hline 17) Já ouviu comentários sobre a Educomunicação? Sim. & $65 \%$ \\
\hline $\begin{array}{l}18) \\
\text { alun }\end{array}$ & 3 \\
\hline
\end{tabular}

Com base nestes dados, elaboramos um roteiro de entrevistas semi-estruturadas, não probabilístico, para possibilitar a interpretação dos assuntos abordados nos questionários e a busca obtenção de respostas a novas perguntas. As interpretações foram dispostas em tópicos, com a inserção de recortes em forma de depoimentos, dos entrevistados, com o objetivo de 
facilitar os diálogos analíticos com nosso quadro teórico. Abaixo, a relação das escolas e dos entrevistados, bem como o desenvolvimento das interpretações.

\section{$\underline{\text { RELAÇÃO DOS ENTREVISTADOS E ESCOLAS }}$}

\begin{tabular}{|c|c|c|c|}
\hline ESCOLA & BAIRRO & $\begin{array}{l}\text { TIPO DE } \\
\text { ESCOLA }\end{array}$ & $\begin{array}{c}\text { DOCENTES } \\
\text { ENTREVISTADOS }\end{array}$ \\
\hline 1) EMEF Armando Cavazza & Engenho Novo & Compartilhada & $3(\mathrm{~A}, \mathrm{~B}, \mathrm{C})$ \\
\hline 2) EMEIEF Alfredo do Carmo & Jardim Belval & $\begin{array}{l}\text { Educação Infantil; } \\
\text { Ens. Fundamental }\end{array}$ & $2(\mathrm{~A}, \mathrm{~B})$ \\
\hline $\begin{array}{l}\text { 3) EMEF Suzete da Costa e } \\
\text { Silva }\end{array}$ & Jd. Maria Helena & Compartilhada & $2(\mathrm{~A}, \mathrm{~B})$ \\
\hline 4) EMEF Caio Prado Júnior & Jd. Califórnia & $1^{\circ}$ ao $9^{\circ}$ ano & $3(\mathrm{~A}, \mathrm{~B}, \mathrm{C})$ \\
\hline 5) EMEF Eizaburo Nomura & Jardim Paulista & $1^{\circ}$ ao $9^{\circ}$ ano & $2(\mathrm{~A}, \mathrm{~B})$ \\
\hline 6) EMEF Nestor de Camargo & Jardim Mutinga & Integral & $6(\mathrm{~A}, \mathrm{~B}, \mathrm{C}, \mathrm{D}, \mathrm{E}, \mathrm{F})$ \\
\hline 7) EMEF Ézio Berzaghi & Jardim Belval & Integral & $3(\mathrm{~A}, \mathrm{~B}, \mathrm{C})$ \\
\hline 8) EMEF Raposo Tavares & Centro & $1^{\circ}$ ao $9^{\circ}$ ano & $2(\mathrm{~A}, \mathrm{~B})$ \\
\hline $\begin{array}{l}\text { 9) EMEF Maria Elisa } \\
\text { Chaluppe }\end{array}$ & Centro & $1^{\circ}$ ao $9^{\circ}$ ano & $1(\mathrm{~A})$ \\
\hline 10) EMEF Ivani Maria Paes & Jd. dos Camargos & Compartilhada & $3(\mathrm{~A}, \mathrm{~B}, \mathrm{C})$ \\
\hline 11) EMEF Alayde C. Macedo & Jardim Silveira & Compartilhada & $3(\mathrm{~A}, \mathrm{~B}, \mathrm{C})$ \\
\hline
\end{tabular}

\subsection{Linguagens da comunicação e adolescentes: os desafios da docência}

Este tópico se refere à pergunta sobre os obstáculos existentes no relacionamento entre o professor de Língua Portuguesa e os alunos dos anos finais do Ensino Fundamental, no tratamento com os gêneros jornalísticos e publicitários, decorrentes da distância entre as faixas etárias. O objetivo foi a compreensão da relação entre gerações diferentes, no contexto escolar, por meio destes textos. Optamos por transformar as entrevistas em depoimentos, sem perder o foco quanto aos questionamentos levantados.

"A minha turma é participativa, trabalhamos o cartum, a charge e vou introduzir a propaganda, embora não seja rígida pelo plano de ensino deste ano, porque acho importante, afinal, ela está em todo o lugar. E o adolescente não tem consciência de que existe alguém que está querendo mudar o comportamento dele por meio desta mensagem. Eu quero deixar claro a eles sobre o poder do gênero, acerca da linguagem persuasiva, sedutora, com a intenção de modificar a opinião. E até que ponto eles vão mudar esta opinião, a favor da propaganda, nos 
outdoor, cartazes, painéis comerciais etc. A questão do consumo desenfreado que eles têm, são adolescentes, eles querem comprar o tempo todo." (Escola 1: Docente A - idade: 36 anos, 17 anos de magistério, $8^{\circ}$ ano)

Durante a entrevista, esta professora demonstrou grande afinidade com os gêneros jornalísticos e publicitários, preocupação com a ideologia, entendimento estrutural de conceitos do jornalismo, muitas vezes característico de um profissional da área. Ela afirmou preferir o trabalho com a linguagem visual, em detrimento da verbal, pela facilidade de utilizar os recursos audiovisuais e se envolver muito com eles, sobretudo nas temáticas televisivas que tratam dessa fase da vida. Em relação à publicidade, apesar de não estar elencada no conteúdo do referido plano, foi inserida, por conta própria, no planejamento da docente.

"Eu tenho certa dificuldade para lidar com estes alunos, digo desta faixa etária, porque eles só conhecem o vocabulário de rua (família, amigos etc.) sempre destaco a eles que, a língua você tem que adequá-la, de acordo com o ambiente. Você não vai à praia de calça, tênis e camiseta. Porque o ambiente não é adequado. É muito relevante esta interface comunicação e educação, porque em termos de linguagem, os adolescentes só utilizam o que chamo de 'internetês' das redes sociais (facebook, twitter, $M S N$ ), às vezes, é uma redação ou dissertação que solicito, uma narrativa, e eles escrevem os códigos deste universo digital (vc; tb; bjks), então, sempre tive que explicar que uma conversa no MSN é diferente de um trabalho acadêmico.” (Escola 2: Docente A - idade: 36 anos, 14 anos de magistério, $9^{\circ}$ ano)

"Eles são muito tímidos, por incrível que pareça. No trabalho com o jornal estabeleci como base os conteúdos estipulados no plano, os gêneros específicos. Então, por exemplo, o editorial, na escola tínhamos alguns jornais recebidos, semanalmente, resolvi utilizá-los. Cerca de 70 exemplares foram distribuídos na sala de aula, neste momento inicial não há lógica de tratar diretamente o gênero editorial, por isto ficamos no manuseio, a exploração, ou seja, uma aula dedicada apenas à observação. Somente na aula posterior é que fiz a introdução das características estruturais. Nas próximas aulas faço comentários e os oriento que este texto fica localizado na contra capa do jornal. Na verdade, o jornal é muito bem-vindo porque dá para se trabalhar com muitas coisas, desde a narrativa até a crônica, gênero este que explorei bastante. Durante estes manuseios, faço explanações sobre a estratégia do jornal de trazer a notícia e, na semana seguinte, uma crônica acerca do fato noticiado. Parece simples, mas os 
adolescentes adoram manusear o impresso e entender estas dinâmicas da comunicação.” (Escola 3: Docente A - idade: 38 anos, 12 anos de magistério, $8^{\circ}$ ano)

"Em relação ao $9^{\circ}$ ano ( $8^{\text {a }}$ série), além de trabalharmos a linguagem visual e os gêneros publicitários (slogans, logotipos etc.), acabamos inserindo a gramática - ensinei tempos e modos verbais. Especificamente nesta aula, o texto era uma propaganda comercial de uma câmera digital, famosa na televisão, que apelava demais ao pagamento facilitado. A partir disto, os alunos começaram a observar esta e outras propagandas de televisão, e perceberam que os verbos encontravam-se sempre no modo imperativo, tanto nos comerciais veiculados na TV como nos anúncios publicitários dos produtos. Após o estudo das cores na propaganda, eles conseguiram relacionar símbolos, por exemplo, a rede de fast food McDonald's foi muito estudada por nós em relação à intencionalidade das nuances, ícones e mensagens subliminares." (Escola 4: Docente A - idade: 41 anos, 20 anos de magistério, $9^{\circ}$ ano)

"Eu acho que, nas atividades em sala com adolescentes, as linguagens da comunicação devem ser as preferenciais, pois não adianta, ainda hoje, a televisão fascina e muito estes alunos e, agora, com a internet, redes sociais, é quase impossível não tratar algo dos textos da comunicação e destes suportes. As novelas, tipo Malhação, Rede Globo, ainda influenciam e muito estes jovens. Eles adoram, por exemplo, quando são orientados a desenvolver uma atividade na qual necessitam utilizar algum meio comunicacional e é grande o desafio ainda de atraí-los, pois são exigentes no trabalho. Tive que modificar meu planejamento, por conta de uma classe do $9^{\circ}$ ano que pediu que eu antecipasse todo o plano anual de Língua Portuguesa. Devido ao pedido, acabei fazendo adequações, de acordo com o interesse dos alunos. Em relação aos jornais, em qualquer suporte, impresso ou audiovisual, os gêneros notícia e reportagem são os mais envolventes, o interessante é que os alunos começavam a manuseá-los e somente depois desta etapa é que fizeram análises com a estrutura e, no final, eles ainda realizaram apresentações em formatos de telejornais, é uma experiência gratificante, eles ficaram nervosos quando erraram; por exemplo, elaboravam o lead da notícia e depois gravavam e colocavam o vídeo no YouTube." (Escola 5: Docente A - idade: 45 anos, 16 anos de magistério, $8^{\circ}$ ano)

Os depoimentos evidenciam que os docentes estão atentos à atual configuração histórica e social, época de uma nova condição comunicativa; como sustentado por John 
Thompson: do desenvolvimento da mídia, transformação espacial e temporal e, consequentemente, das novas maneiras de ação e interação entre os indivíduos.

Os adolescentes integram um mundo repleto de imagens, interpretações, reconstruções, distribuídas pelos meios de comunicação, mas, além disto, como o próprio Thompson aponta, o mundo da revolução digital.

De acordo com os depoimentos, os docentes "imigrantes digitais" encontram mais dificuldades para entender o comportamento dos "nativos digitais", expressões de Marc Prensky, do que para trabalhar com textos jornalísticos e publicitários junto a eles. Segundo o americano, estes jovens, que aprendem sozinhos com as tecnologias e as fazem uma verdadeira extensão de si mesmos, estão acostumados a usar celulares de bolso, enviarem mensagens instantâneas, a passarem a maior parte de suas vidas "conectados". Na visão do autor, além de processarem com maior velocidade as informações, os nativos dão primazia às imagens, ao contrário dos imigrantes, que preferem o texto. Sendo assim, os gêneros jornalísticos notícia e reportagem são os preferidos dos educadores por estes acreditarem que atraem mais a atenção dos discentes, independentemente dos suportes. Os gêneros informativos (nota, notícia, reportagem e entrevista) e opinativos (editorial, comentário, artigo, resenha, coluna, crônica, caricatura), classificação de José Marques de Melo, são os mais usados pelos professores dos anos finais do Ensino Fundamental.

Os textos publicitários também estão presentes por causa de seus recursos de imagem. Uma das docentes entrevistadas citou uma atividade com propaganda realizada em sala com o $9^{\circ}$ ano sobre a rede de fast food McDonald's.

Neste aspecto, retomamos Isleide Fontenelle, em $O$ nome da marca: McDonald's, fetichismo e cultura descartável, que trata da construção imagética, do jogo do faz de conta entre a linguagem publicitária e o lugar da marca, no caso da multinacional, na sociedade midiática (2002:266):

O desejo da marca de se fazer presente na "mídia-realidade", através de acontecimentos surpreendentes, vai ao encontro do funcionamento da mídia de notícias, em que se misturam, cada vez mais, informação e diversão. E os profissionais de marketing embaralham ainda mais essas fronteiras, em busca do tom da realidade, que precisam imprimir às suas marcas.

Constatamos, pelas entrevistas, que a televisão é o meio que mais atinge os adolescentes, de acordo com os professores, mais ainda do que a internet. As telenovelas 
juvenis, como "Malhação", da emissora Rede Globo, foram citadas várias vezes por atraírem e possibilitarem comentários, debates, leitura de notícias etc. Entendemos que, por mais "conectados" que possam estar, referência à linguagem digital, os jovens ainda se pautam pela televisão, bem como os próprios educadores.

Em sala, a utilização do jornalismo e publicidade coloca desafios e conflitos aos docentes, entre os mais explícitos: as lacunas culturais entre as gerações, a facilidade dos jovens na apropriação destas linguagens e dos dispositivos tecnológicos e, principalmente, a concorrência discursiva.

Ainda há descompassos - o discurso subterrâneo, como já apontado por Adilson Citelli (1999), continua presente no ambiente educacional: de um lado as formações discursivas oficializadas; de outro a explosão das linguagens dos mais diversos meios tendo os alunos como receptores/emissores (in) diretos.

A partir dessas informações, a investigação prosseguiu de forma a verificar outras questões ideológicas e conceituais na ação pedagógica, ou seja, a visão dos especialistas de Língua Portuguesa ao compartilharem as mensagens comunicacionais com os discentes.

\subsection{O jornalismo e a publicidade em Língua Portuguesa}

Na disciplina de Língua Portuguesa, a produção de textos jornalísticos se centraliza na linguagem verbal, sendo a notícia o seu grande filão. Esta constatação encontra sustentação na ideia de Ciro Marcondes Filho - para o autor, a utilidade deste gênero está em extrair somente o fato específico que a originou com disposição múltipla aos meios (impresso, TV, rádio e internet).

Quanto à recepção das informações noticiadas, inserida com frequência no discurso e ação pedagógicos, o estudioso alerta para o jogo psicológico que ela desencadeia uma mistura de alívio e preocupação, imperceptíveis na maioria dos casos. E explica (1986:14): "não as notícias isoladamente, via de regra, mas o conjunto delas, o noticiário como um todo, ou mesmo a programação noticiosa jogam com este duplo caráter da notícia. Trata-se da dialética da atemorização e da tranquilização, que compõe o fato noticioso”.

"A reportagem é um gênero que, geralmente, consegue levantar debates em sala de aula, por exemplo, o julgamento de Lindemberg Fernandes Alves, em fevereiro de 2012, pela morte do caso da jovem Eloá. Amplamente divulgado na mídia, o assunto tomou conta da sala, em várias aulas estudamos a estrutura do texto, depois eles chegaram a fazer gravações 
em vídeo e realizaram a apresentação em formato de telejornal. Depois do debate, ainda pensei em colocar orações coordenadas ou subordinadas, mas não dava, era o fim. Onde eu trabalho não tem data show - se tivesse seria ótimo, afinal, os meios nos ajudam muito. Por exemplo, tem um professor que possui data show e nos empresta. Então, houve uma aula na qual mostrei uns vídeos sobre as figuras de linguagem - procurei e baixei na internet e levei meu notebook. Na sala, eles ficaram maravilhados e me entenderam rapidamente." (Escola 3: Docente B - idade: 34 anos, 10 anos de magistério, $8^{\circ}$ ano)

Durante esta entrevista, a professora fez muitas colocações reivindicatórias, motivadas pelas carências materiais que afirmou existir em sua escola. A unidade escolar em que leciona é compartilhada, ou seja, o prédio é da rede estadual, que possui Ensino Médio (períodos manhã e noite) e o município fica com o Ensino Fundamental (manhã e tarde), mantendo-o com seus recursos e funcionários.

"Quando a apostila chegou, no primeiro bimestre, percebi que tratava de textos jornalísticos - pensei, em seguida, sobre como despertar o interesse por estes gêneros sem que a aula ficasse desinteressante, então, tive que pesquisar mais. Conversei com outros professores de Língua Portuguesa e com o professor de informática da escola para pensarmos em um projeto sobre o gênero jornalístico. Foi quando chegamos à ideia de um portal na web para que estes alunos produzissem notícias. A princípio, fiquei um pouco temerosa, mas bastou falar a eles que iriam aprender a produzir uma notícia e, sobretudo, que outros alunos da escola iriam ler a publicação que ficaram muito interessados. Então, o projeto começou a ganhar forma, iniciamos com o gênero notícia nas aulas de Língua Portuguesa dos $8^{\circ}$ e $9^{\circ}$ anos ( $7^{\mathrm{a}}$ e $8^{\mathrm{a}}$ séries) e, depois, nas duas aulas de informática semanais, os alunos redigiam a notícia e aprendiam a postá-la no site da escola, elaborado pelo professor de informática. $\mathrm{Ou}$ seja, assim que estudavam a estrutura do gênero, no caso, a notícia, eles a redigiam na sala de informática e me enviavam por e-mail. Éramos quatro professores da área envolvidos nesse projeto, cada um responsável pela correção dos textos de seus alunos. O impressionante foi quando um aluno escreveu uma notícia e ficou muito ansioso pela publicação desse material no portal. Na época, o professor de informática, morava no bairro e o jovem foi até a casa dele cobrar a postagem do texto no site." (Escola 6: Docente A - idade: 38 anos, 5 anos de magistério, $9^{\circ}$ ano) 
"O editorial foi o gênero mais difícil dos jornalísticos para o trabalho em sala. Para eles entenderem o que é um editorial, durante várias aulas levei jornais impressos para manuseio. Explicava a localização do texto e comentava acerca da responsabilidade da pessoa que o escrevia, bem como sobre sua função perante os leitores. Comentei também que sua função, geralmente, é uma crítica a alguma situação, um fato. Em seguida, após o trabalho com este gênero, entender os outros textos jornalísticos acabou sendo mais fácil para as atividades em sala com os alunos." (Escola 6: Docente B - idade: 45 anos, 08 anos de magistério, $8^{\circ}$ ano)

"Em minha opinião, o importante ao trabalhar com os textos comunicacionais é o seguinte: o aluno, quando produz um texto sem objetivo, não tem o seu interesse despertado. Agora, se ele, por exemplo, aprender gêneros, como: notícia, entrevista e/ou anúncio publicitário, com a intenção de produzi-los para a comunidade escolar, aí ele se identifica com a função social e enxerga nestas mensagens muita utilidade. Este processo é muito interessante, afinal, eles assumem também, por meio da produção destes, o seu papel na sociedade. E isto faz deles um cidadão, na acepção da palavra.” (Escola 1: Docente B - idade: 36 anos, 17 anos de magistério, $8^{\circ}$ ano)

“Eu trabalhei com anúncios publicitários priorizando a questão ideológica, os elementos persuasivos, os jogos de sedução propostos. Para tanto, utilizei a estratégia inicial com impressos, por meio de revistas e os orientei até a procura na internet de anúncios das grandes agências, mas centralizei as buscas, sobretudo, nas propagandas comerciais da televisão. Não adianta negar, pois este meio atrai muito os jovens, então, depois do estudo da estrutura, função textual, os alunos, por si só, acabam pesquisando em outros meios. No caso da TV, depois da pesquisa, alguns gravaram até vídeos caseiros e colocaram no YouTube Analisamos muitas propagandas e mantivemos o enfoque na linguagem publicitária, as características textuais e abordamos também as questões do consumo.” (Escola 7 : Docente A - idade: 39 anos, 17 anos de magistério, $9^{\circ}$ ano)

“A publicidade é sedutora aos alunos, sobretudo aqueles comerciais que veiculam na TV aberta. A partir da proposta curricular da área com este gênero, no $9^{\circ}$ ano o $2^{\circ}$ bimestre é dedicado a ele, resolvi trazer mais recursos do audiovisual em minhas aulas por conta disto. Afinal, mesmo que a mensagem da propaganda esteja impressa é necessário estudar a leitura de imagens e os recursos desde cores, símbolos, formas e ainda orientar sua leitura, pois os 
alunos já estão no último ano do Ensino Fundamental. Eu acredito que não adianta apresentar outras temáticas, pois as propagandas relacionadas ao esporte e marcas são preferenciais desta faixa etária, sem contar os modelitos dos atores das telenovelas e questões envolvendo relacionamentos amorosos. Com a intenção de usar estes textos, propus trabalhos em grupos, cada um analisou determinada propaganda com uma temática eleita pela sala: no caso, comerciais sobre marca e esporte; com o tema em mãos os alunos divididos analisaram as mensagens nos vários meios de comunicação. Um verdadeiro exercício de leitura dos conteúdos implícitos, os quais o adolescente, na maioria das vezes, não consegue perceber, e aproveitei para mostrar a importância da constituição dos sentidos por meio das linguagens não verbais." (Escola 6: Docente $\mathrm{C}$ - idade: 36 anos, 17 anos de magistério, $8^{\circ}$ ano)

Os gêneros reportagem, entrevista e crônica estão na lista de preferências dos textos midiáticos utilizados pelos professores.

Sobre o uso do impresso, os educadores ratificam as orientações propostas pela pesquisadora Maria Alice Faria quanto à inserção de uma série de atividades com o jornal, desde a inicial manipulação a outras atividades, atitudes comuns nas ações escolares, justificadas pela necessidade de manejo do material concretamente.

O telejornalismo também é um parâmetro audiovisual em sala e as (tele) novelas figuram como geradoras de modismos, gírias e entretenimento com este público de alunos.

Os entrevistados, em sua maioria, abordam em suas aulas temáticas assuntos apresentados em programas televisivos não houve, entretanto, relatos de educadores quanto aos recursos ideológicos persuasivos do jornal nas atividades em sala.

Ao tratarmos da televisão, independentemente do gênero, ela assume no ambiente educacional um caráter normativo, ainda que implícito, como exposto por Rosa Maria Bueno Fischer (2002) em O dispositivo pedagógico da mídia: modos de educar e na (e pela) TV, que nomeia este mecanismo de "dispositivo pedagógico da mídia".

Fischer trata da linguagem que nomeia como stricto sensu da mídia, particularmente da TV, do conceito de televisibilidade, com base em Beatriz Sarlo, a qual seleciona um grupo de categorias:

A autorreferência (o modo como a TV fala de si mesma através de diferentes produtos); a repetição (imagens e estruturas que retornam, propiciando tranquilidade, prazer e identificação); o aval de especialistas (para legitimação das verdades narradas); a informação didática (colocando o espectador na posição de quem deve ser cotidianamente ser ensinado); a 
opção por um vocabulário facilitado, traduzido, especialmente quando relacionado a termos técnicos etc. (FISCHER, 2002:156).

Percebemos que o telejornalismo e a telenovela, como já anunciado, são determinantes nos assuntos da disciplina de Língua Portuguesa e direcionadores de pesquisas na web pelos alunos. Assim, por mais adeptos que sejam às tecnologias digitais, os jovens ainda são pautados pelo conteúdo da TV na busca por informações e lazer. Inclusive, estes profissionais da educação ratificam esta constatação até nas escolhas de textos impressos, pelos quais optam em larga escala.

Os formatos jornalísticos televisivos são estudados em termos estruturais e, neste contexto, tornam-se motivadores de debates, comentários e outras ações orais e escritas.

Eugênio Bucci e Maria Rita Kehl, em Videologias (2004:41) discorrem sobre a natureza da televisão contemporânea:

Os programas de ficção cada vez mais buscam sustentar-se em argumentos da realidade (tanto que, no Brasil, a telenovela é tanto mais presente quanto mais consegue propor uma síntese do imaginário social); quanto aos programas de telejornalismo, estes precisam se adequar a uma narrativa mais ou menos melodramática (o andamento dos telejornais busca capturar o telespectador pelo desejo e pela emoção). Ou seja, ficção e realidade se invertem na (estética da) nova ordem.

Outro aspecto observado é a suposta neutralidade destes noticiários, como discorre Bucci: "a ilusão do discurso jornalístico é descrever a realidade sem nela interferir" (2004:30).

Contrariando a observação de Bucci, o discurso dos professores não apresentou relatos sobre verificações de caráter crítico quanto às manipulações implícitas. Em compensação, os docentes descrevem com grande frequência estas ações no trabalho com os gêneros publicitários, os quais são utilizados de forma a desenvolver análises aprofundadas sobre consumo e manipulação ideológica.

Para Eliana Nagamini (2000), a publicidade constrói seus discursos através do universo iconográfico, resgata aspectos do individual no coletivo. Analisar os mecanismos de sua construção discursiva é importante para a compreensão dos valores e comportamentos aceitos pela sociedade e enraizados em nossa cultura. Na visão da autora (2000:76): 
A publicidade, no entanto, é mais do que um mecanismo de estratégia de venda; ela é um reflexo da sociedade na medida em que espelha valores sociais e reconstrói arquétipos que estão no imaginário de todos. Precisa ser construída a partir de recursos sonoros/visuais/linguísticos capazes de tornar a mensagem atraente e memorável.

$\mathrm{Na}$ ação didática com o uso desses gêneros, os educadores se posicionaram de forma a serem mediadores destes trabalhos com apontamentos críticos acerca destes textos com os alunos. Ainda neste eixo temático, Gilles Lipovetsky defende que o desejo não é derivado da manipulação publicitária, pois o consumidor não é enganado, mas encantado por ela, “ ela não consegue fazer com que se deseje o indesejável" (2000:7).

O estudioso vai contra a corrente apocalíptica, entretanto, quando fala de consumidores refere-se a adultos. Quer dizer, na verdade, se refletirmos que os adolescentes ainda estão formando sua identidade, a partir dos valores transmitidos, perceberemos o porquê dos docentes citarem, várias vezes, a importância de direcionarem as atividades dos adolescentes com as mensagens publicitárias por conta das características dos recursos imagéticos e mensagens implícitas. Diante destas constatações, verificamos os reais motivos da opção dos professores por determinados gêneros em detrimento de outros, tópico a ser tratado logo a seguir.

\subsection{Os porquês da comunicação no uso pedagógico}

Existem fatores determinantes na escolha dos gêneros do jornalismo e da publicidade em Língua Portuguesa no Ensino Fundamental de Barueri. Elencamos dois que acreditamos importantes neste processo seletivo: o plano de ensino oficial da área, com orientações para uso da maioria dos gêneros jornalísticos ( $8^{\circ}$ ano) e também vários publicitários $\left(9^{\circ}\right.$ ano). Outro aspecto a ser levantado é a imposição da condição comunicativa contemporânea, pois consideramos o fato de se tratar de público adolescente, que convive com este universo de dispositivos, linguagens e tecnologias. Apresentamos os depoimentos dos docentes acerca desta temática e os objetivos pedagógicos quanto ao uso deste material. 
"Em sala, claro que o foco principal é fazer com que o aluno entenda o gênero, saiba identificá-lo e caracterizá-lo, mas também me preocupo muito com o fato dele conseguir ler, afinal, é um momento que eu posso reservar, já que na maioria das casas de meus alunos a leitura é muito escassa. Eu acredito que os textos comunicacionais possibilitam maior facilidade no tratamento com a leitura e escrita, visto que chamam a atenção do adolescente. Com estes textos, ele vai querer ler, entender, observar e recontar o que viu ou leu. Geralmente, eu peço para ele recontar a mensagem lida. Na notícia, eu queria que ele recontasse e preservasse o lead (onde, o quê, com quem?), assim observo as dificuldades com o gênero. Mas acho interessante, por exemplo, mostrar como o lead é item fundamental preservado em cada meio: digital, impresso, rádio, televisão, notícia é sempre notícia!" (Escola 10: Docente A - idade: 43 anos, 15 anos de magistério, $8^{\circ}$ ano)

"Quando verifiquei no plano de ensino que os bimestres continham gêneros do circuito midiático, já que leciono para os $8^{\circ}$ e $9^{\circ}$ anos, pensei, imediatamente, na possibilidade de, por meio destes textos, exigir mais habilidades em termos de leitura e escrita. Na verdade, quando proponho o estudo de uma notícia, reportagem, entrevista ou anúncios, penso que são focos atrativos para além da estrutura textual em si e também para avançarmos nas exigências de habilidades como a interpretação. É mais fácil chamar a atenção por conta dos meios, uma matéria jornalística veiculada na televisão possibilita uma série de estudos: desde debates, análises críticas, reescrita, sem falar que podemos explorá-la no impresso; na verdade, muitos de meus alunos, por conta própria, já buscam informações e comentários na internet, celular e redes sociais (Facebook e Orkut).” (Escola 1: Docente C - idade: 36 anos, 17 anos de magistério, $8^{\circ}$ ano)

“A crônica foi o gênero que mais explorei, talvez pela facilidade em encontrá-la nos meios e também por conter uma mensagem que eles gostam muito; tem cronistas que agradam os jovens como, por exemplo, o autor de novela Walcir Carrasco que, inclusive, possui artigos no material pedagógico municipal e meus alunos amavam. Carrasco possui uma característica que os adolescentes gostam: a mistura de assuntos do universo deles, desde o famoso namorar e ficar, até situações com a inserção de códigos da internet, blogs e celular. Os alunos buscam a informação, tanto pelo texto impresso como por outros meios, com isto, o trabalho com a análise de estrutura textual fica bem melhor. Sem contar que eles redigem usando muitos ícones e símbolos, em seus textos, o que aproveito na exploração dos sentidos, algo que o adolescente tem dificuldades de perceber. E a crônica jornalística possibilita a 
exploração de notícias, reportagens, entrevistas e até de propagandas." (Escola 11: Docente A - idade: 40 anos, 18 anos de magistério, $9^{\circ}$ ano)

"Além dos objetivos característicos, reconhecimento estrutural dos gêneros, a questão do ensino aos alunos de linguagens comunicacionais é válida. Gostei bastante do resultado das atividades com resenhas e sinopses de filmes. Aliás, nestas atividades foi possível o uso de recursos audiovisuais, no caso, a linguagem cinematográfica no material e até outras que eles quiseram ver. Então, primeiramente, analisamos a estrutura do gênero, vocabulários, leitura, interpretação e, posteriormente, a produção deles. Mas é interessante que, para elaborar a resenha do filme, no momento da elaboração os alunos buscaram muitas fontes, principalmente a internet. Eles trouxeram para a sala sinopses e resenhas de críticos famosos sobre o cinema. Foi um estudo interessante porque aliei linguagens de gêneros distintos." (Escola 5: Docente B - idade: 50 anos, 25 anos de magistério, $8^{\circ}$ ano)

Manuel Castells defende que, para a inclusão do indivíduo neste novo modelo comunicacional, é necessário falar de internet. Em entrevista ${ }^{41}$, Castells expõe que estamos vivendo em um sistema de comunicação duplo, em que os meios de comunicação não reinam sozinhos; surgiu o que chama de "autocomunicação de massa" - uma comunicação que nós mesmos selecionamos, entretanto, tem o potencial de chegar às massas, ou àqueles grupos definidos em nossas redes. Sobre o questionamento acerca da inexistência de uma pessoa sem estar na internet, é enfático, afirma que essa pergunta perdeu o sentido. De acordo com o sociólogo, não vivemos na internet, mas com ela. Ela é uma parte essencial de nossa vida, além de uma cultura de liberdade.

Em relação aos circuitos midiáticos, retomamos Adilson Citelli (2010b), quanto à presença dos meios em sala de aula, para quem perguntas com base em críticas estruturais, definições de funções e acerca dos porquês do uso, do entendimento de suas linguagens, são importantes para a sobrevivência dos indivíduos no atual modelo social. Vistas desta forma, são pertinentes e requisitadas por todos, não basta apenas a constatação de que são necessárias, assim, como Castells se referiu à internet, pois a importância de sua existência neste ambiente tornou-se óbvia.

\footnotetext{
${ }^{41}$ Entrevista de Manuel Castells, em janeiro de 2012, concedida ao programa Europa Abierta, da rádio e TV pública espanhola. Disponível em: <http://www.outraspalavras.net/2012/01/17/castells-debate-os-dilemas-dainternet/>. Acesso em 10/06/2012.
} 
Em nossa pesquisa, constatamos que as estratégias docentes relatadas estão interligadas às necessidades que os próprios alunos apresentam quanto às temáticas e conteúdos em sala. São questões propostas a partir de conteúdos midiáticos que transpassam o planejamento proposto e exigem novas buscas de informações pelo professor para atingir as expectativas dos alunos quanto às atividades.

Dando continuidade à nossa investigação, abordaremos questões relacionadas à dinâmica dos dispositivos (planos de ensino, currículo, material pedagógico, disciplina) conceito de Giorgio Agamben ${ }^{42}$.

\subsection{As implicações do material pedagógico no uso dos gêneros midiáticos}

Desde 2006, os cadernos de apoio pedagógico foram distribuídos aos alunos da Educação Infantil e Ensino Fundamental. Em 2012, este dispositivo gerou debates e reflexões.

Em relação a este tópico, observamos que, durante o processo de aplicação dos questionários aos professores, no primeiro semestre de 2011, a circulação do material ocorreu normalmente. A opinião dos docentes quanto à sua utilização se centralizava na redução de sua liberdade de planejamento.

Contudo, no segundo semestre daquele ano e nos primeiros meses de 2012, na ausência destes conteúdos impressos, visto que a circulação foi interrompida, constatamos que houve alterações na maneira de pensar o trabalho pedagógico com as linguagens comunicacionais em Língua Portuguesa.

Sendo assim, em busca do entendimento da assertiva acima, esboçaremos os pontos de vista dos educadores pesquisados, continuando os diálogos com nosso referencial teórico.

“Sim. O material pronto é limitante, mas eu não fiquei presa ao Caderno de Apoio. Quando o Caderno chegou, eu tinha que trabalhar os conteúdos elencados para a área e no $8^{\circ}$ ano ( $7^{\mathrm{a}}$ série) são elencados textos jornalísticos, nos quatro bimestres, ou seja, durante todo o ano letivo. Mas, por exemplo, a notícia que tinha lá era velha, de 2009 e 2010, já não chamava mais a atenção, aliás, era sobre vacinação de idosos, uma temática que para os adolescentes

\footnotetext{
42 Dispositivo, para Giorgio Agamben (com base em Foucault), "é qualquer coisa que tenha de algum modo a capacidade de capturar, orientar, determinar, interceptar, modelar gestos e os discursos dos seres viventes". Agamben divide o existente em dois grupos: de um lado, os seres viventes (ou substância) e, de outro, os dispositivos em que estes são incessantemente capturados.
} 
não é nada atrativa. Aproveito e registro aqui minha crítica, neste sentido, aos elaboradores. A estratégia que utilizei foi encontrar uma notícia atual, voltada a um assunto que chamasse a atenção deles. Na verdade, confesso, seguia rigorosamente a ordem dos gêneros apresentada neste caderno. Porém, em relação aos temas propostos, não. Então, recorria a informações do universo adolescente, senão o trabalho pedagógico perde a funcionalidade em sala." (Escola 2: Docente B - idade: 35 anos, 10 anos de magistério, $8^{\circ}$ ano)

"Antes, honestamente, pensava que o material de apoio municipal era muito fragmentado, fiz inúmeras críticas a ele. Contudo, com a adoção dos livros didáticos do Ministério da Educação (MEC) e a retirada de circulação daquele material do município, posso confessar: ai, que saudade do material impresso daqui, quero que ele volte logo! Digo isto porque, sinceramente, o livro do governo federal, o qual utilizo, eu vejo como fora da realidade dos alunos. Deixe-me explicar: os vocabulários, os enunciados e os gêneros textuais parecem distante demais destes jovens, pois priorizam contos e algumas crônicas, mas muito antigos, como: Contos da Terra, de Edgar Alan Poe, de 1800, e abordam muito pouco sobre os gêneros jornalísticos, os publicitários nem são trabalhados, excetos em alguns anúncios.” (Escola 4: Docente $\mathrm{C}$ - idade: 46 anos, 22 anos de magistério, $9^{\circ}$ ano)

Em suas falas, as referidas professoras demonstraram certa dicotomia acerca do uso dos cadernos, pois, de um lado, afirmaram que o material cerceava a ação pedagógica devido à "obrigatoriedade" de uso, implícita e até explícita, por parte de gestores, pais e comunidade escolar. De outro lado, com a disponibilização do planejamento anual, proposta curricular e o material na web, apontaram a sensação de vigilância e controle do ensino em sala de aula.

Em Barueri, no ciclo final, $8^{o}$ e $9^{\circ}$ anos do Ensino Fundamental ( $7^{\mathrm{a}}$ e $8^{\mathrm{a}}$ séries), os gêneros jornalísticos são predominantes, com espaço também aos publicitários, textos cujas mensagens suscitam posicionamentos, análises críticas e autonomia.

Por falar em autonomia, resgatamos Jacques Rancière em $O$ mestre ignorante: cinco lições sobre a emancipação intelectual (2002) que nos traz essa busca emancipatória ao retratar o método do professor Joseph Jacotot . Este por sua vez, entendia, portanto, que a relação mestre-aluno pautava-se pelos diálogos entre aquele que sabe e aquele que não sabe. Após, ser exilado, percebeu que é possível ensinar sim quem não sabe, pois em sua visão, temos condições iguais de inteligência, contudo precisamos de estímulos. 
Para Jacotot, segundo Rancière (2002) “o aluno será capaz de aprender qualquer coisa. Qualquer coisa pode aprender por si, utilizando o que sabe, observando o que está a sua frente, dizendo o que viu, verificando o que disseram". Neste método:

"O aluno deve ter tudo por ele mesmo, comparar incessantemente e sempre responder à tríplice questão: o que vês? $\mathrm{O}$ que pensas disso? $\mathrm{O}$ que fazes com isso? E assim até o infinito. Mas, esse infinito não é mais segredo do mestre, é marcha do aluno" (RANCIÈRE, 2002:44).

"Nós somos conhecedores da Língua e pelo contato, ou melhor, pela exigência social de entendermos melhor as mensagens dos meios de comunicação e seus gêneros, somos induzidos a aprofundar nossos conhecimentos acerca deles. No material da rede está explicitado, ainda que sucintamente, a estrutura destes textos, tais como a notícia, com base estrutural específica, o lead. Entretanto, é adaptada de acordo com o meio em que estará sendo emitida (impresso, televisão, rádio ou internet). Por isto, apesar de utilizar outros recursos com os gêneros do jornalismo e da publicidade, incluí também diferentes aparatos. Eu vou ser sincera, tomo por base alguns pontos do material, sim, e creio que, sobretudo os professores novatos e aqueles que não são tão ligados às mensagens do tipo não verbais, como as publicitárias, necessitam deste norteador. Sendo assim, observo como grande perda a sua retirada de circulação. Outro fator que acho importante neste aspecto é o fato do aluno ficar 'sem direcionamento', pois necessita ter o material concreto para visualização e manejo." (Escola 8: Docente B - idade: 52anos, 24 anos de magistério, $8^{\circ}$ ano)

"O lado bom do material é que ele segue, rigorosamente, o planejamento anual de Língua Portuguesa do município. Então, facilita o tratar dos textos jornalísticos e publicitários. E o fato de estar inserido nos cadernos dos alunos obriga-nos o seu estudo. Digo isto porque não adianta, o adolescente até vai para a internet buscar informações, mas precisa de estímulo e, geralmente, isto começa na sala com o impresso, passando pela televisão que o atrai ainda com a maior força, para depois ser direcionado para as redes sociais etc." (Escola :7 Docente B - idade: 36 anos, 17 anos de magistério, $8^{\circ}$ ano)

“Inicialmente, quando analisei o plano de ensino do $8^{\circ}$ ano, pensei, poxa vida, vou lecionar pela primeira vez para este público e vou tratar de gêneros do jornalismo o ano todo, como fazer isto? Mas, como os alunos ainda estavam com o material em mãos, percebi que seria mais fácil a elaboração das atividades. É óbvio que estes textos necessitam de 
atualização e formulações de novos contextos. Contudo, numa sala com 40 alunos, sem recursos tecnológicos e/ou material impresso, fica quase impossível fazer uma ação pedagógica qualitativa. A temática que o jornalismo e a publicidade trazem no cotidiano são muito dinâmicas e aproveito para apresentar e exigir habilidades tão cobradas em nossa disciplina: leitura, interpretação e produção textual." (Escola 9: Docente A - idade: 42 anos, 22 anos de magistério, $8^{\circ}$ ano)

Para analisar as entrevistas, recorremos à ordem discursiva de Michel Foucault, para quem a organização do que é dito ou não utiliza determinados mecanismos de controle; nas palavras do autor: "a produção do discurso é ao mesmo tempo controlada, selecionada, organizada e redistribuída por certo número de procedimentos que têm por função conjurar poderes e perigos, dominar seus acontecimentos aleatórios" (FOUCAULT, 2008:8-9).

$\mathrm{O}$ francês entende que o sistema educacional, com os saberes e poderes que traz consigo, é uma maneira de manter ou modificar a apropriação dos discursos. Sendo assim, instrumentos como currículo, proposta de área, plano de ensino e o material pedagógico, caso da rede de Barueri, tornam-se legitimadores dos poderes instituídos e são ratificados como dispositivos.

O que é afinal um sistema de ensino senão uma ritualização da palavra; senão uma qualificação e uma fixação dos papéis para os sujeitos que falam; senão a constituição de um grupo doutrinário ao menos difuso; senão uma distribuição e uma apropriação do discurso com seus poderes e seus saberes? (FOUCAULT, 2008:44-45)

Em outras palavras, Adilson Citelli, quanto os encadeamentos hierárquicos no ambiente educacional, elucida a construção da organização dos conteúdos em sua análise sobre como os documentos oficiais se tornam verdadeiros "manuais" com definição de objetivos, habilidades e avaliações.

Pela via da estrutura escolar, considerando sua lógica institucional presente, parece não existir outra forma de aprender senão tendo em mira os conteúdos como finalidades em si e que aliados a outros postos na mesma série terminariam por legitimar as unidades (de conhecimento) chamadas de disciplinas. (CITELLI, 2004a:109) 
Em relação às linguagens comunicacionais, constatamos críticas sobre a forma como são elencadas no material de apoio existente. Entretanto, com a retirada de circulação deste, abriu-se uma lacuna que provocou modificações no comportamento de muitos educadores quanto às próprias ações didáticas. De acordo com os relatos os docentes de Língua Portuguesa começaram, de maneira mais sistemática, a procurar novos recursos, meios e aparatos tecnológicos e pesquisar mais acerca da temática. Os alunos também perpetuam esta institucionalização, ainda que sob a leitura do "direito adquirido" forçado pelos pais e comunidade escolar.

Em contrapartida, a inserção dos textos de comunicação no currículo, ou seja, na proposta da disciplina de Língua Portuguesa pela Secretaria de Educação, é um processo que parece natural. Entendemos como natural algo que os professores admitem ser necessário e já foi incorporado ao cotidiano de suas práticas. Nas entrevistas, os docentes foram incisivos quanto às mensagens da mídia como objeto de estudo na disciplina, corroborando o que já afirmara Georges Snyders, ou seja, com esses textos fazendo parte dos conteúdos curriculares, é possível dar-lhes um tratamento crítico adequado, aprofundar o superficial e romper com o que houver de generalização e preconceito.

O pedagogo aponta para a distância entre a escola, leia-se também professores, e o mundo, com o dia-a-dia dos alunos, o que, na visão de Snyders, parece ser a verdadeira vida.

Para investigar o distanciamento entre professores, alunos e instituição, apontado por Snyders, incluímos em nosso roteiro de entrevista perguntas sobre a infraestrutura e a tecnologia no tratamento com os meios comunicacionais e suas linguagens, considerando a área de atuação dos sujeitos e o contexto físico das escolas municipais.

Abaixo, os depoimentos sobre a temática investigada.

\subsection{Infraestrutura e recursos tecnológicos}

A importância do aspecto estrutural, inserido no discurso docente, remete-nos às condições e dificuldades encontradas nas ações didáticas com atividades relacionadas as linguagens da comunicação nas unidades escolares de Ensino Fundamental. Afinal, essas instituições possuem diversificadas condições socioeconômicas, com índices de variação, que influenciam na aplicação de atividades que requisitam os meios comunicacionais e suportes tecnológicos. Sendo assim, o desenvolvimento de práticas pedagógicas que se apropriam do 
jornalismo e publicidade esbarra em necessidades relacionadas à existência física dos laboratórios de informática, acesso à internet e dispositivos digitais. Estes itens foram citados pelos professores, cujos depoimentos apresentaremos a seguir, legitimando a referida assertiva.

“O que acontece é a discrepância etária dos professores mais antigos que não têm tanto contato com a tecnologia. Eu, por exemplo, não sei mexer no programa Photoshop ${ }^{43}$, me considero da geração intermediária, mas consigo acompanhar estes adolescentes. Hoje é praticamente impossível falarmos em comunicação sem relacionarmos à internet. Então, o fato de existir condições na escola na qual leciono, de período integral, como um laboratório equipado de informática, com computador para cada aluno, uma sala de vídeo com data show, uma biblioteca equipada, espaço físico para atividades, me incentiva a buscar novas didáticas que alcancem com maior precisão este público. Bem diferente da outra escola em que leciono, da rede estadual, que, por falta de material e espaço, me obriga, muitas vezes, a limitar-me no material impresso que, por sinal, sou eu quem tem que fornecer, empobrecendo, de certa maneira, o trabalho em sala e não motivando a atenção dos jovens do Ensino Médio.” (Escola 6: Docente D - idade: 38 anos, 15 anos de magistério, $9^{\circ}$ ano)

"Antes de começar a falar, quero deixar claro que a unidade escolar em que leciono no município é compartilhada, ou seja, divide espaço físico com alunos do Ensino Médio da rede estadual. Digo isto porque ela não possui laboratório de informática, o que existe é do estado e a biblioteca também é do estado. Não possui data show, o que dificulta quando, por exemplo, quero trabalhar conteúdos relacionados aos gêneros da publicidade e do jornalismo tais como as charges, os cartuns e as caricaturas, que eles gostam muito, e sem estes recursos eles não se interessam tanto. Ainda quando tínhamos os cadernos de apoio pedagógico, estes conteúdos eram coloridos e conseguia me virar em sala despertando um pouco o interesse deles. Porque não é fácil, eles têm tantos recursos, o celular, apesar da proibição do uso em sala, às vezes, falamos algo que eles vão pesquisar via celular e já vêm com as respostas imediatamente.” (Escola 10: Docente B - idade: 41 anos, 12 anos de magistério, $8^{\circ}$ ano)

"A minha escola é compartilhada com o Estado, existe uma sala de informática do município, mas, sinceramente é preferível que o aluno não vá até lá, pois são três alunos por

\footnotetext{
43 Adobe Photoshop é um software lançado em 1996 caracterizado como editor de imagens bidirecionais, desenvolvido pela Adobe Systems.
} 
computador e aqueles micros de lá estão praticamente sucateados. Não tem acesso à internet, os programas são ultrapassados e os jovens já não se interessam mais, então, é melhor que fiquem na sala de aula mesmo. Por isto, em se tratando dos gêneros do jornalismo, no planejamento durante o ano todo no $8^{\circ}$ ano, prefiro o impresso (jornal e revista) e trato, a partir deles, os editoriais, notícias, reportagens e crônicas. Utilizo a biblioteca da escola, que me ajuda na inserção de projetos com o jornalismo." (Escola 3: Docente B - idade: 39 anos, 11 anos de magistério, $9^{\circ}$ ano)

Ela faz parte de um grupo de docentes de Língua Portuguesa da unidade escolar que realizou um projeto de jornalismo em parceira com a Revista Época (Editora Globo) no qual, por meio de reportagens publicadas fornecidas aos alunos, a editora estabelecia uma temática para o estudo da estrutura do gênero e sua produção, para exposição mensal na escola, bem como nas feiras semestrais abertas à comunidade. Este projeto contou com visitas à editora e passeios que enfocaram os assuntos abordados pelas matérias jornalísticas em sala de aula.

"Em minha escola existe um laboratório de informática, mas, geralmente, eu o uso como finalização das unidades de estudo propostas. Sou adepto de usar o data show em sala de aula (levo meu notebook) e direcioná-la de acordo com o gênero a ser estudado. Fiz um trabalho com publicidade no qual apresentei diversos slogans e marcas e eles, em grupos, pesquisavam em casa e apresentavam aos colegas em sala o que encontraram e as características da mensagem. Neste caso, alguns alunos até levaram um notebook para a apresentação, nossa, a aula foi enriquecedora. Não vejo vantagem em levá-los ao laboratório e fazer pesquisa anteriormente, acho importante direcionar a busca e estudar o gênero primeiro em sala para, então, solicitar a pesquisa fora da escola e depois realizarmos a exposição grupal a todos." (Escola 8: Docente A - idade: 34 anos, 15 anos de magistério, $9^{\circ}$ ano)

"Eu sou do tipo que, apesar da idade, já estou com 52 anos, acompanho as transformações dos adolescentes, acredita? Gosto desta faixa etária justamente porque ela nos obriga a buscar o novo, diariamente. Não é possível estagnar com estes alunos, eles amam o mundo digital. Então, quando resolvi buscar com eles crônicas jornalísticas, eles me sugeriram os $b \log s^{44}$. Por isto, solicitei a pesquisa em casa, mas, como muitos não possuem

\footnotetext{
${ }^{44}$ Blog (contração do termo inglês web log, que significa diário na web): site cuja estrutura permite a atualização rápida a partir da inserção de informações, comentários ou notícias particulares, funcionando como um diário on line.
} 
acesso à internet, resolvi usar o laboratório de informática da escola. Como vários discentes já haviam encontrado blogs de crônicas famosos, foi mais fácil o trabalho, cronistas como Luís Fernando Veríssimo, Arnaldo Jabor, foram os mais procurados, a justificativa é que eles tratam de assuntos que os alunos já assistiram em notícias ou programas de televisão." (Escola 6: Docente E - idade: 52 anos, 27 anos de magistério, $8^{\circ}$ ano)

Com base nos depoimentos, é possível visualizar que a razão instrumental continua sendo um desafio permanente, como destacou Hugo Assmann (2000); no tocante à aprendizagem e ao conhecimento, lembra que chegamos a uma transformação sem precedentes de ecologias $\operatorname{cognitivas}^{45}$, tanto das internas da escola como das que lhe são externas, mas que interferem profundamente nela.

Os docentes pesquisados se encontram em locais nos quais a infraestrutura institucional interfere nas metodologias aplicadas em sala, sobretudo ao tratarmos dos textos midiáticos. Entretanto, este aspecto não pode ser considerado somente de forma negativa, pois eles mesmos declararam que, muitas vezes, são "obrigados" a modificarem sua prática por conta dos recursos materiais disponíveis. Ainda discursam como se a tecnologia e os próprios meios comunicacionais fossem recursos e suportes, demonstrando que não romperam totalmente com o conceito instrumental e que muitas vezes não se percebem como mediadores deste aspecto.

Inspirado em Paulo Freire, Moacir Gadotti (2003) acredita que o compromisso do professor emancipador é dar sentido ao ensino e à sua função na sociedade. Para o autor, depende exclusivamente do docente buscar um novo posicionamento de organizador do conhecimento.

Durante as entrevistas, muitos dos educadores se mostraram preocupados com as modificações ocorridas socialmente e afirmaram não estar tão preparados para as alterações comunicativas e tecnológicas ocorridas nas últimas décadas. Destaque dado aos gêneros digitais, que estão presentes em sala de aula pela exigência do público de alunos, ou seja, os adolescentes, por estarem imersos neste mundo, levam à sala estas composições textuais e não apenas forçam, de certa maneira, a alteração do planejamento dos docentes, mas também

\footnotetext{
${ }^{45} \mathrm{O}$ conceito é de Pierre Lévy, definido como o estudo das dimensões técnicas e coletivas da cognição. "O meio ecológico no qual as representações se propagam é composto por dois grandes conjuntos: as mentes humanas e as redes técnicas de armazenamento, de transformação e de transmissão das representações. A aparição de tecnologias intelectuais como a escrita ou a informática transformam o meio no qual se propagam as representações." (Lévy, 1993, p. 138)
} 
configuram estas mensagens no cotidiano das aulas, um processo que se torna cada vez mais natural.

Portanto, além dos recursos materiais e físicos, questões de cunhos pedagógicos e da interface foram muito presentes nos conteúdos das entrevistas, bem como discursos acerca de ações que legitimam uma prática nem tão libertária quanto se presume. Apresentamos, a seguir, depoimentos sobre estes itens.

\subsection{Interface, formação continuada e currículo}

Ao tratarmos da formação docente em serviço e da interligação entre Comunicação e Educação em sala de aula, os professores colocaram questões pertinentes acerca dos cursos disponibilizados no Centro de Aperfeiçoamento de Professores (CAP), espaço localizado na Secretaria Municipal da Educação, dos currículos dos cursos de graduação em Letras e do conceito de Educomunicação.

"Sinto falta das formações dos últimos dois anos. Deixe-me explicar, de cursos voltados ao mundo digital, pois preciso de orientações para o adentrar num laboratório de informática e desenvolver atividades com estes gêneros digitais. Contudo, por outro lado, reconheço que os cursos de Letras também têm sua parcela de culpa, afinal, não trazem disciplinas que estudem mais a fundo a comunicação e seus textos. Creio que isto necessita mudar, olhe o nosso público de alunos, de que adianta disciplinas sem valores na prática?" (Escola 7: Docente C - idade: 40 anos, 11 anos de magistério, $9^{\circ}$ ano)

"Particularmente, acho que neste ano de 2011, a formação melhorou muito, pois temos um direcionamento específico para a nossa área, o professor/formador é ótimo e estamos estudando as teorias sobre os gêneros textuais. Por mais que se fale acerca deste assunto, sinceramente, temos muito ainda que atualizar. Ainda sinto falta de formações voltadas ao mundo digital, na medida em que essas novas linguagens que os adolescentes gostam tanto, os blogs, as conversas instantâneas (MSN) predominam nos diálogos dos discentes em sala. Quanto ao conceito de Educomunicação, já ouvi falar, superficialmente, é algo relacionado ao uso de textos midiáticos em sala de aula. Ultimamente, devido ao plano de ensino municipal, eu os incorporei de vez em meu planejamento semanal, até porque com a faixa etária que 
leciono é necessário algo que desperte o interesse deles, senão nada flui." (Escola 10: Docente C - idade: 43 anos, 20 anos de magistério, $8^{\circ}$ ano)

"Sinceramente, por mais que a formação continuada seja específica para a nossa área, creio que poderia ser muito melhor. Acho que se direcionem no CAP um professor/formador para nós que utilizasse o laboratório de informática com atividades voltadas ao uso dos chamados gêneros da internet, seria ótimo. Em Língua Portuguesa, estes textos do mundo midiático são prioritários com este público. Não que os contos e outros gêneros não o sejam, mas a realidade com que, por exemplo, uma notícia televisiva atinge esses jovens, não tem igual. Em relação ao currículo, eu acho que a formação acadêmica tem muito mais que se modificar do que a continuada, porque nós que estudamos Letras temos muitas disciplinas que não colaboram em nada com a prática pedagógica. Faz falta disciplinas que estudem essas questões comunicacionais. Eu tive um professor que chegou a tratar questões da interface comunicação e educação com um livro do professor Adilson Citelli. É preciso uma revisão curricular, desde a graduação. Quanto ao conceito de Educomunicação, desconheço o seu significado, entretanto, em relação aos livros do Citelli, acho importante a interface entre as duas áreas. Outro ponto que acho fundamental é que é preciso considerar o engessamento que temos em relação ao sistema." (Escola 11: Docente B - idade: 45 anos, 21 anos de magistério, $9^{\circ}$ ano)

"Fico observando meus alunos serem tão dispostos à comunicação que sinto a defasagem que tenho, desde minha formação acadêmica. Sinceramente, quando saí da faculdade não estava preparada para lidar com estas novas gerações. Existem lacunas que nós devemos correr atrás e nos atualizarmos. Os cursos de formação continuada sempre colaboram, tenho minhas críticas, afinal, poderiam contribuir e muito nesta temática da comunicação. Necessito de atividades práticas e que me orientem no trabalho com os gêneros midiáticos de forma a auxiliá-los no processo crítico destes. O adolescente é facilmente levado pelas propagandas. Em relação ao conceito de Educomunicação, eu o vi na proposta curricular municipal. Já tinha ouvido antes falar dela com uma palestra do professor Ismar Soares porque minha prima estudou na ECA/USP. Mas, acho que antes de pensarmos numa nova área, como ele propõe, é necessário o aprofundamento da interface ao menos nos ambientes formais de ensino. Barueri precisa de cursos voltados a esta interface." (Escola 6: Docente C - idade: 41 anos, 15 anos de magistério, $9^{\circ}$ ano) 
“Eu gostei muito da formação que ocorreu em 2009, era do Ministério da Educação (MEC), o GESTAR ${ }^{46}$ Nossa, foi um ano muito gratificante, estudamos somente os gêneros textuais com oficinas práticas, inclusive, dos textos da mídia. Nestes momentos, eu entendi a necessidade da interface comunicação e educação, e acredito que o diálogo entre as áreas é fundamental, já que os alunos de hoje estão imersos neste mundo totalmente comunicacional. Sinto muita responsabilidade no desenvolvimento da autonomia de meus alunos, tanto que achei importante a inserção dos gêneros do jornalismo no plano de ensino de Barueri. Afinal, por ser formada em Letras, às vezes acho que deveria sempre ter um comunicador envolvido na elaboração destes materiais, porque eles têm uma visão mais aberta, às vezes questiono se eu não deveria ter feito Jornalismo em vez de Letras." (Escola 11: Docente C - idade: 48 anos, 26 anos de magistério, $8^{\circ}$ ano)

Reconhecer, como propõe Adilson Citelli (2011), a linguagem como presença dinamizadora básica para todo o processo comunicacional e educativo é compreender o admitir a sua nobre função entre as áreas. Sendo assim:

\begin{abstract}
Afirmada a ideia do papel relevante que a linguagem desempenha para viabilizar todo o processo comunicacional e, certamente, o da educação, do ensino- aprendizagem, evidencia-se um óbvio nível de recorrência entre os dois componentes, motivo pelo qual a expressão educomunicação vem sendo invocada como reveladora de um fenômeno de inter-relação, interfaces e cruzamentos que envolvem os presentes mecanismos de produção, circulação e recepção do conhecimento.” (CITELLI, 2011:196-19)
\end{abstract}

As atuais condições comunicacionais, legitimadas, em sua maioria, pelos alunos, exigem novas estratégias e o uso dos meios e recursos do audiovisual e digital, o que interfere

\footnotetext{
46 O Programa Gestão de Aprendizagem Escolar (GESTAR) do Ministério da Educação oferece formação continuada em Língua Portuguesa e Matemática aos professores (do sexto ao nono anos) do Ensino Fundamental em exercício nas escolas públicas.

Disponível em:

$<$ http://portal.mec.gov.br/index.php?option=com_content\&view=article\&id=12380\&Itemid=649>. Acesso em 10/06/2012.
} 
na ação do professor em sala. Exigem, também, profundas reflexões, como exposto por Costa $(2011: 1)^{47}$ :

As mediações tecnológicas quando interpretadas para além dos conteúdos, e quando a temática requer análise da linguagem dos meios e a constituição de sentidos, portanto, ajuizadas no campo estético e da produção de conhecimento, adquirem particular significado; o de observar se a apropriação dos suportes midiáticos se dá na perspectiva de emancipação ou numa outra que é instrumental, que tende a não perceber a relação entre objeto/meio tecnológico e a racionalidade que permeia o mundo industrial e a administração do saber.

A investigação realizada diante desta colocação apresenta um caráter dicotômico entre os docentes de Língua Portuguesa pesquisados, pois, de um lado, encontramos um grupo de professores, não necessariamente com menor faixa etária, que acompanha as mudanças e segue objetivos específicos em prol da autonomia do alunos e de si mesmos, apesar dos mecanismos existentes para cerceá-los. De outro, educadores ainda presos discursivamente e didaticamente à concepção instrumental e que não identificam a relação objeto e meio tecnológico.

Em relação à formação acadêmica, a dissertação A formação do professor na universidade para a inter-relação comunicação/educação, de Gabriela Felippe Rodrigues Metzker, defendida em 2010 na ECA/USP, mostra resultados que confirmam as queixas manifestas pelos docentes de Língua Portuguesa.

A pesquisadora analisou os cursos de graduação em Letras e Pedagogia da Universidade de São Paulo (USP) e da Universidade Cruzeiro do Sul (Unicsul). Constatou que o futuro professor não recebe, ou recebe de forma periférica, uma formação voltada para trabalhar a inter-relação comunicação/educação em sala de aula. Os cursos de pedagogia, à época, ofereciam disciplinas voltadas a esta temática, mas de caráter optativo. Entretanto, em relação a Letras, nenhuma das instituições apresentou no currículo matérias que estudassem a interface.

Resgatamos a noção de vontade da verdade, de Michel Foucault, para a abordagem do currículo e da proposta pedagógica disciplinar, traduzida neste pensamento (2008:17):

\footnotetext{
${ }^{47}$ Citação do professor Dr. Belarmino César Guimarães Costa em exame de qualificação deste trabalho, no dia 03/11/2011, na ECA/USP, redigido em relatório entregue à aluna.
} 
Ora, essa vontade da verdade, como os outros sistemas de exclusão, apoia-se sobre um suporte institucional: é ao mesmo tempo reforçada e reconduzida por todo um compacto conjunto de práticas como a pedagogia, é claro, como o sistema dos livros, da edição, das bibliotecas, como as sociedades de sábios outrora, os laboratórios hoje. Mas, ela é também reconduzida, mais profundamente sem dúvida, pelo modo como o saber é aplicado em uma sociedade, como é valorizado, distribuído, repartido e de certo modo atribuído.

Os modos de distribuição do discurso institucional, no aspecto geral, indo desde a elaboração das leis e documentos orientadores até a recepção do aluno e o caminhar para a sociedade, ainda conotam mais a dependência do que a educação autônoma, tão apregoada. Em relação aos educandos se posicionam cada vez mais em favor de sua autonomia, a seguir dados e depoimentos que corroboram na assertiva.

\subsection{Os alunos (receptores/emissores)}

O objetivo da aplicação da técnica de observação indireta (questionários e entrevistas) com os discentes foi investigar aspectos apontados pelos professores, considerando os alunos como sujeitos receptores/emissores destas ações didáticas com as linguagens da comunicação. Consideramos, neste sentido, a reflexão de Mauro Wilton de Sousa (2006:138):

O que se observa na escola é a chegada de um aluno que vê, olha, ouve, sente, sonha, ri e chora, percebe, fala e aprende de forma drasticamente distinta daquela prestigiada pela escola, de um jeito bem articulado com essas tecnologias e códigos da imagem e do som. Um aluno bem pouco familiarizado com a cultura escrita, racional, abstrata e lógica e, no entanto, bem mais à vontade com a narratividade veloz do audiovisual, com sua sensorialidade emocional e sua fragmentação instantânea, tudo isso tocado muitas vezes pelo próprio ritmo da sociedade de consumo que caracteriza os das atuais. 
A partir desta concepção de alunos contemporâneos, aplicamos questionários nas unidades escolares contendo 9 questões, respondidas por um total de 50 alunos dos anos finais, sendo 25 do $8^{\circ}$ ano ( $7^{\mathrm{a}}$ série) e 25 do $9^{\circ}$ ano ( $8^{\mathrm{a}}$ série) do Ensino Fundamental de Barueri.

Em relação à faixa etária, os discentes de $8^{\circ}$ ano possuem, em sua maioria, 13 anos de idade, e os de $9^{\circ}$ ano se encontram na faixa dos 14. Elencamos seis unidades escolares onde os professores foram pesquisados e que continham as duas séries: 1) EMEF Alayde Couto Macedo; 2) EMEF Ivani Maria Paes; 3) EMEF Armando Cavazza - as três escolas compartilhadas (município e estado); 4) EMEF Nestor de Camargo (período integral); 5) EMEF Eizaburo Nomura (1 $1^{\circ}$ ao $9^{\circ}$ ano); 6) EMEF Suzete da Costa e Silva (compartilhada).

À medida que acompanhávamos este processo, observávamos os diálogos dos jovens, apresentados após a exibição das tabelas. Estas, por sua vez, pontuam quantitativamente um breve levantamento de aspectos tecnológicos e comunicacionais dos adolescentes.

A escolha dos sujeitos entrevistados partiu dos próprios adolescentes, nos intervalos das aulas - diante dos grupos, eles se manifestavam sobre participar da conversa. Sentávamos em um local sem barulho e as conversas aconteciam em grupo, para não intimidá-los. Observamos que não eram todos os alunos que estavam dispostos a conversar, como apontado pela investigação dos docentes. Longe do grupo, vários se mostraram tímidos frente às perguntas. Sendo assim, totalizamos 12 depoimentos democráticos e espontâneos dos alunos. Na sequência a tabulação das questões, seguidas do perfil e depoimentos dos discentes.

\section{A) Equipamentos tecnológicos}

\begin{tabular}{|c|c|c|}
\hline $\begin{array}{l}\text { 1) Quais aparelhos tecnológicos você } \\
\text { possui? }\end{array}$ & $\mathbf{8}^{\mathbf{o}}$ ano & $\mathbf{9}^{\mathbf{0}}$ ano \\
\hline a) Celular. & 25 & 25 \\
\hline b) iPhone. & 2 & 2 \\
\hline c) Computador. & 19 & 22 \\
\hline d) Notebook. & 5 & 5 \\
\hline
\end{tabular}




\begin{tabular}{|l|c|c|}
\hline 2) Quais são os seus preferidos? & $\mathbf{8}^{\mathbf{0}}$ ano & $\mathbf{9}^{\mathbf{0}}$ ano \\
\hline a) Celular e computador. & 25 & 25 \\
\hline b) Celular e iPhone. & 24 & 23 \\
\hline c) notebook, celular e \\
$\begin{array}{l}\text { computador. } \\
\text { d) Outros. }\end{array}$ & 19 & 22 \\
\hline
\end{tabular}

\begin{tabular}{|c|c|c|}
\hline $\begin{array}{l}\text { 3) Na escola, você usa o computador } \\
\text { para fazer pesquisas escolares no: }\end{array}$ & $8^{\circ}$ ano & $9^{\circ}$ ano \\
\hline a) Laboratório de informática. & 20 & 21 \\
\hline b) Sala de aula. & 0 & 2 \\
\hline c) Biblioteca. & 5 & 3 \\
\hline $\begin{array}{l}\text { d) Não usa computador porque não existe } \\
\text { sala e estes equipamentos na escola. }\end{array}$ & 0 & 0 \\
\hline
\end{tabular}

\section{Observações:}

Os celulares e os computadores tradicionais são dispositivos usados pela maioria dos discentes, se não em casa, na unidade escolar. O uso do laboratório pelos jovens independe da ida ou não do professor. Com os professores de informática, existe a possibilidade de terminar atividades que antes afirmaram não conseguir sem a sua presença, pois é necessário um professor responsável pelos alunos neste espaço.

B) Informações, linguagens e rede sociais.

\begin{tabular}{|c|c|c|}
\hline $\begin{array}{l}\text { 4) Quais atividades você realiza } \\
\text { diariamente: }\end{array}$ & $8^{\circ}$ ano & $9^{\circ}$ ano \\
\hline $\begin{array}{l}\text { a) Entrar na internet e postar em redes } \\
\text { sociais (facebook, twitter, Orkut). }\end{array}$ & 25 & 25 \\
\hline b) Bater papo no MSN Messenger. & 24 & 22 \\
\hline c) Procurar vídeos no YouTube. & 2 & 6 \\
\hline d) Nenhuma das alternativas. & 0 & 0 \\
\hline
\end{tabular}




\begin{tabular}{|l|c|c|}
\hline 5) Você costuma receber informação por: & $\mathbf{8}^{\mathbf{0}}$ ano & $\mathbf{9}^{\mathbf{0}}$ ano \\
\hline a) Internet. & 10 & 15 \\
\hline b) Televisão. & 5 & 2 \\
\hline c) Rádio. & 0 & 0 \\
\hline d) Celular. & 15 & 8 \\
\hline
\end{tabular}

\begin{tabular}{|c|c|c|}
\hline $\begin{array}{l}\text { 6) Qual professor usa mais os recursos } \\
\text { tecnológicos: }\end{array}$ & $\mathbf{8}^{\mathbf{0}}$ ano & $\mathbf{9}^{\mathbf{0}}$ ano \\
\hline a) Geografia. & 2 & 3 \\
\hline b) História. & 2 & 3 \\
\hline c) Língua Portuguesa. & 6 & 2 \\
\hline d) Informática. & 15 & 18 \\
\hline
\end{tabular}

\section{Observações:}

Os alunos confirmaram o conceito de "nativos digitais" - afirmam entrar diariamente em redes sociais (facebook), enviar mensagens pelo twitter e conversar via MSN Messenger. Em depoimentos, demonstraram que isto é uma ação cotidiana e natural. Quanto aos gêneros do jornalismo e da publicidade, de acordo com o planejamento docente estabelecido, os alunos do $8^{\mathbf{0}}$ ano, por terem textos jornalísticos durante todo o ano letivo, afirmaram que os especialistas de Língua Portuguesa os utilizam mais (notícias, reportagens, editorial e crônica); o mesmo ocorre com os textos publicitários, citados pela maioria dos alunos do $9^{\circ}$ ano, corroborando o plano de ensino da rede educacional.

\section{C) Ações pedagógicas e gêneros do jornalismo e da públicidade}

\begin{tabular}{|c|c|c|}
\hline $\begin{array}{l}\text { 7) Em sala de aula, o professor de Língua } \\
\text { Portuguesa realiza mais atividades com: }\end{array}$ & $\mathbf{8}^{\mathbf{0}}$ ano & $\mathbf{9}^{\mathbf{0}}$ ano \\
\hline $\begin{array}{c}\text { a) Notícias, reportagens, editorial e } \\
\text { crônica. }\end{array}$ & 22 & 8 \\
\hline \begin{tabular}{l} 
b) $\begin{array}{l}\text { Folder, cartazes, anúncios e } \\
\text { propagandas. }\end{array}$ \\
\hline c) Charge, cartum, biografia e caricatura.
\end{tabular} & 2 & 10 \\
\hline d) Todas as alternativas. & 0 & 2 \\
\hline
\end{tabular}




\begin{tabular}{|c|c|c|}
\hline $\begin{array}{l}\text { 8) Quando você lê ou assiste a uma notícia, } \\
\text { qual assunto chama mais sua atenção: }\end{array}$ & $\mathbf{8}^{\mathbf{0}}$ ano & $\mathbf{9}^{\mathbf{0}}$ ano \\
\hline a) Esportes. & 2 & 2 \\
\hline b) Relacionamentos (Ficar/Namorar). & 0 & 0 \\
\hline c) Novela. & 10 & 12 \\
\hline d) Casos de polícia. & 12 & 10 \\
\hline e) Entrevistas e debates. & 1 & 1 \\
\hline
\end{tabular}

\begin{tabular}{|c|c|c|}
\hline $\begin{array}{l}\text { 9) Quanto às mensagens de propaganda, } \\
\text { você prefere estudar: }\end{array}$ & $\mathbf{8}^{\mathbf{0}}$ ano & $\mathbf{9}^{\mathbf{0}}$ ano \\
\hline a) Anúncios sobre venda de produto. & 1 & 22 \\
\hline $\begin{array}{c}\text { b) Anúncios de venda com ídolos de } \\
\text { esporte, novela, videogame. }\end{array}$ & 23 & 1 \\
\hline c) Não gosta deste tipo de texto. & 0 & 0 \\
\hline d) Anúncios comerciais de TV. & 2 & \\
\hline
\end{tabular}

\section{Observações:}

Sobre os educadores, obviamente os docentes/instrutores dos laboratórios são os mais citados pelos discentes como os que mais desenvolvem atividades neste espaço, pelos conhecimentos da tecnologia. Interessante foi observar que os programas televisivos policiais e as telenovelas são as preferências dos jovens desta faixa etária e que gostam de estudar, lhes desperta mais a atenção, por exemplo, um texto publicitário relacionado a algum ídolo da juventude.

\section{Perfil do adolescente dos anos finais}

Com base nas entrevistas, observamos características típicas de adolescentes da faixa etária pesquisada: possuem celular e computador, usam diariamente redes sociais e programas de mensagens instantâneas, como o MSN Messenger, têm acesso à internet, preferem assistir na televisão programas policiais e (tele) novelas. A força da referência de ídolos (do esporte, telenovela ou videogame) é motivo de grande interesse em estudar determinado gênero, como o anúncio publicitário, em sala de aula. 
As ações e gostos destes discentes ratificam o pensamento de Marc Prensky (2006), para quem, hoje, os educandos (nativos digitais) são multifacetados, inserem-se e aceitam facilmente a novidade tecnológica, proliferando as mudanças em todos os aspectos, pesquisam de modo diferente e recorrem às informações da internet, local no qual partilham experiências, ideias, comentários.

\section{Os depoimentos}

As entrevistas, realizadas com 12 jovens dos anos finais de cada escola, serão apresentadas em depoimentos acerca das três temáticas dos questionários, incluindo, na visão destes alunos, a atuação dos docentes de Língua Portuguesa. Com vistas a nos aproximarmos dos jovens, realizamos essas conversas nos intervalos escolares, como já citado, de maneira a deixá-los bem à vontade para expressarem seus pensamentos.

"Eu gosto de usar o celular para tudo, a escola proíbe. Às vezes eu uso; por exemplo, eu acompanho a novela Avenida Brasil, da emissora Rede Globo, todos os dias antes de entrar na aula, pelo meu celular já verifico o capítulo do dia. Gosto de saber o que vai acontecer com o Tufão (personagem do ator Murilo Benício), na trama um ex-jogador de futebol. Daí a professora de Português vem querer falar de vacinação contra a gripe, daí eu acho um saco e quero falar da saída do Ronaldinho do Flamengo, ela não quer. Mas, não é notícia também?” (aluno 1, 13 anos, $8^{\circ}$ ano, EMEF Eizaburo Nomura)

“Eu amo escrever. Sonho em ser jornalista, então, com o projeto da professora com a Revista Época (Editora Globo) eu pude aprender a importância de escrever uma notícia, a diferença entre reportagem e entrevista. Nossa, assisto aquele jornal da televisão com a Ana Paula Padrão, ela é linda. E outra, nada como as ações e as imagens, por isto sou fã do jornal televisivo." (aluno 2: 14 anos, $8^{\circ}$ ano, EMEF Alayde Couto Macedo)

“O problema da maioria dos professores é serem atrasados, quer dizer, eles parecem que vivem no passado. Poxa vida, será que é tão difícil entrar no YouTube e salvar um vídeo de qualquer jornal e levar no laboratório, ou pedir aquele aparelho (referência ao data show) para nos mostrar? Vixi, ela fica insistindo com o texto impresso e agora, sem os cadernos de apoio pedagógico, ficou muito pior, eu não gosto dessa disciplina.” (aluno 3: 14 anos, $9^{\circ}$ ano, EMEF Armando Cavazza) 
"Cara, que saco, a professora trouxe uma notícia daquele cara famoso que fala e escreve bem a Língua, esqueci o nome. Então, o tal cara é o top do assunto, mas, em vez de discutirmos sobre ele, eu nem o conhecia. Ela já começou com a interpretação textual, sabe, puxa vida, que coisa chata!” (aluno 6: 14 anos, $9^{\circ}$ ano, EMEF Alayde Couto Macedo)

"O professor fez um concurso de anúncio publicitário, cada grupo teve que estudar os formatos, as características daquele texto, procurar na internet, assistir a uns vídeos comerciais no YouTube, entrar em sites de agências famosas, tipo aquela do Washington Olivetto. Mano, que divertido! E depois tivemos que apresentar, meu grupo gravou pelo celular e com o notebook de meu amigo apresentamos para a sala, show, véio, show." (aluno 5: 14 anos, $9^{\circ}$ ano, EMEF Nestor de Camargo)

"Amo a professora de Português, porque ela conseguiu nos mostrar alguns textos como as notícias, reportagens em vários locais desde impressos, televisão, rádio, revista e internet, demorou um bimestre, mas, ao menos ela deixou nós escolhermos a temática e pesquisarmos fora da escola. Quer dizer, a notícia tem detalhes de acordo com o meio, é tão gostoso estudá-la assim. Até porque as meninas ficaram com a novela das oito e os meninos com o programa esporte espetacular (Rede Globo)." (aluno 4: 13 anos, $8^{\circ}$ ano, EMEF Armando Cavazza)

"Eu adoro assistir programas policiais e leio notícias deste tipo, a professora disse que é muito violento, toda vez que eu falava que assistia àquele cara, o Datena, ela olhava feio para mim. Fui ficando irritado, até que um dia, eu falei: por que você não explica o que acha de errado neste programa, então? Fica aí falando que é sensacionalista, o que significa isto? Aí, ela ficou brava, tudo. Mas, acredita que na outra aula de Língua Portuguesa, ela trouxe dois vídeos com os dois programas que o Datena faz, que são diferentes, e ela explicou tudo?! Eu continuo assistindo, mas, sei que ele é sensacionalista, que quer audiência, então fico esperto." (aluno 7: 14 anos, $9^{\circ}$ ano, EMEF Eizaburo Nomura)

“O tema era entrevista. Então, pensei no Jô Soares ou Marília Gabriela. E teve um grupo que escolheu o povo do programa Pânico (Rede Bandeirantes), tipo o Ceará, o Vesgo entrevistando, ah, é brincadeira, e a professora aceitou. Aí estudamos como deve ser uma entrevista, e quem disse que o Pânico é um programa de entrevista, ele é humorístico, mas, a 
professora deixou o grupo se apresentar, vou só bagunça, conclusão, quem está certo?” (aluno 8: 13 anos, $8^{\circ}$ ano, EMEF Ivani Maria Paes)

"Estudamos a notícia, entrevista, artigo de opinião, editorial, reportagens, em cada veículo de comunicação, no final, fomos divididos em grupo e cada um ficava com um gênero do jornalismo em determinado meio (impresso, rádio, televisão, internet). Depois cada um apresentou para a sala. Foi muito legal, o grupo que apresentou o telejornal colocou o vídeo no YouTube, muito show." (aluno 9: 13 anos, $8^{\circ}$ ano, EMEF Nestor de Camargo)

"Outro dia a professora veio com uma conversa que a gente tava falando muito errado. E trouxe uma conversa do $M S N$ para observarmos, ela explicou que não podemos abreviar as palavras daquela forma, somente naquele ambiente. Cara, que saco eu fiquei com mania de escrever tudo abreviado. Aí ela vem com aquela história de elaborar uma charge, como gosto de desenhar, foi legal, eu fiz duas garotas em frente ao computador, e várias abreviaturas, demonstrando que estavam falando pelo MSN, fui super elogiada pelo desenho (risos)." (aluno 10: 14 anos, $9^{\circ}$ ano, EMEF Suzete da Costa e Silva)

"Era para pesquisar uma reportagem e ela disse para assistirmos ao programa Globo Repórter, é demais. Ela pode até gostar deste tipo de programa, mas ainda, se fosse uma Malhação, uma série tipo Casseta e Planeta, ah, eu não quis, ninguém gostou. Daí o pessoal foi assistir a aquele programa do Caco Barcellos, Profissão Repórter, acredita, aprendi o que é reportagem com ele, mas, não conta para a minha professora, tá (risos)." (aluno 11: 13 anos, $8^{\circ}$ ano, EMEF Nestor de Camargo)

"Eu estou adorando sem os cadernos de apoio, é coisa para as crianças menores. A professora de Língua Portuguesa ficava seguindo tudo o que estava lá e não deixava muito espaço para discussões, debates. Agora, que não tem mais, nossa, ela mudou, ficou mais legal, porque está deixando nós falarmos sobre os temas que gostamos. Estudamos as reportagens, já tínhamos visto notícias, mas, agora, ela resolveu nos levar ao laboratório de informática, lá tem internet para pesquisar, pela primeira vez achei esta disciplina mais legal, porque comecei a entender o que é uma verdadeira reportagem." (aluno 12: 13 anos, $8^{\circ}$ ano, EMEF Suzete da Costa e Silva) 


\section{Considerações}

Entre os relatos dos professores, já apresentados, e os depoimentos dos discentes encontramos conflitos. O pano de fundo perpassa a questão do uso tecnológico na escola e as ações pedagógicas com o jornalismo ou publicidade em sala de aula. Observamos um aspecto cada vez mais emergente: a necessidade de diálogos entre gerações de contextos sóciohistóricos diferentes. Se, de um lado, encontra-se um docente que, quer seja pelo sistema, currículo ou vontade, perpetua uma prática didática que não considera a chamada tecnicidade junto aos infanto-juvenis, que resiste à noção, tal como postula Jesús Martín-Barbero (2006), de que o computador nos coloca frente a um novo tipo de textualidade, com escritas e suportes que facilitam a oralidade e a leitura dos mais jovens, Martín-Barbero mesmo nos lembra que, de outro, estão os jovens, sedentos por atividades pedagógicas que contribuam cada vez mais com este universo digital nos quais estão imersos.

Cita (2006:7):

É nas novas gerações que essa cumplicidade opera mais fortemente, não porque os jovens não saibam ler ou leiam pouco, mas, sim, porque sua leitura já não tem o livro como eixo e centro da cultura. Deste modo é a própria noção de leitura que está em questão, obrigando-nos a pensar a desordem estética que as escritas eletrônicas e a experiência audiovisual introduzem.

Não é possível ignorar, estas alterações de linguagem, escrita, leitura e concepção estética advindas com os movimentos da internet. Essas experimentações, tão comuns às crianças e adolescentes, estão cada vez mais presentes em sala de aula, obrigando os educadores a repensarem seus métodos. 


\section{TESTE DAS HIPÓTESES}

A interpretação dos dados nos permitiu testar as hipóteses inicialmente levantadas de forma a verificar se elas foram confirmadas ou rejeitadas, total ou parcialmente.

Consideramos confirmadas as seguintes hipóteses:

- O professor de Língua Portuguesa tem dificuldades de acesso e infraestrutura em sua prática pedagógica para trabalhar a diversidade das linguagens jornalística e publicitária, o que contribui para que as linguagens da comunicação da cultura escrita sejam preferidas.

As dificuldades que os professores encontram para a inserção cotidiana dos gêneros do jornalismo e publicidade estão ligadas a três variáveis: acesso, infraestrutura e interesse. A primeira é complexa porque envolve questões pessoais e profissionais relacionadas aos ambientes doméstico e escolar, ou seja, muitos possuem acessibilidade aos recursos tecnológicos e audiovisuais em casa, outros somente na escola. Em relação à estrutura organizacional, existem grandes variações diretamente dependentes do prédio, espaços físicos, gestão pedagógica, localização geográfica e recursos disponíveis. E, por último, o aspecto fundamental, o interesse do educador pelo uso destes textos. Quanto à cultura escrita, priorizam as mensagens de suportes do impresso, tais como notícias e propagandas comerciais, os mais requisitados pela facilidade de lidar com este material e pelo conhecimento de estratégias didáticas. Apesar da faixa etária dos discentes, na visão dos docentes, há necessidade de manusear o material concreto para possibilitar, posteriormente, o trabalho com outros tipos de suportes.

Houve relatos do desconhecimento de ações em sala de aula com os meios audiovisuais, sobretudo do universo digital. Vários entrevistados demonstraram que os formatos do telejornalismo e as propagandas do tipo McDonald's e outras grandes redes são muito analisados nas aulas de Língua Portuguesa pelo fato de atraírem a atenção dos jovens e possibilitarem o estudo de mensagens verbais e não-verbais para a construção de sentidos. Em relação aos gêneros jornalísticos e publicitários do universo digital, os educadores relataram a falta de cursos de formação que os orientem, apesar do reconhecimento de sua necessidade cotidiana e da facilitação que ocasionam na interação com os adolescentes. 
- As linguagens no suporte do impresso, jornalísticas e publicitárias, ainda são hegemônicas nas aulas dos professores de Língua Portuguesa no tocante à aquisição da competência leitora e escritora dos alunos.

As linguagens do impresso são dominantes nas aulas de Língua Portuguesa: concorrem com outros recursos tecnológicos e meios audiovisuais, tais como televisão, DVD e data show, na unidade escolar ou salas-ambientes, no caso das escolas integrais, e, assim, desafiam os professores na busca de novas estratégias didáticas. Os docentes entrevistados reafirmaram, por diversas vezes, a preferência pela cultura escrita impressa em virtude das exigências da área e suas responsabilidades. Apesar de não admitirem, demonstram estar mais familiarizados com este suporte por causa das dificuldades com os meios digitais. Entretanto, reconhecem a importância de um equilíbrio entre o uso de diversos meios e aparatos, porque percebem não ser mais possível lecionar para os adolescentes sem ideias atrativas à faixa etária.

Nas unidades escolares de período integral, com melhor infraestrutura tecnológica, encontramos vários projetos com as linguagens jornalísticas e publicitárias no universo digital, entretanto, por se tratar especificamente da referida disciplina, também existe a recorrência aos textos do impresso por conta das habilidades relacionadas à leitura e escrita. Houve entrevistas nas quais os docentes relataram a preferência por atividades manuscritas não apenas pelo receio de plágio, muito comum junto às pesquisas por meio da internet, mas devido à necessidade de leitura, interpretação e produção escrita dos discentes.

Em análise das habilidades elencadas no plano de ensino do $8^{\circ}$ ano ( $7^{\mathrm{a}}$ série), encontramos ações como: identificar, diferenciar, ler, interpretar e comparar informações nos textos e suportes de circulação das mensagens, o que justifica a opção dos educadores. Em relação ao $9^{\circ}$ ano ( $8^{\text {a }}$ série), a compreensão de sentido e intencionalidade textual, a expressão da opinião por meio da escrita, as relações entre o verbal e os recursos gráficos (visuais), a revisão e a reescrita são as habilidades que contribuem para a opção pelos gêneros do jornalismo e publicidade impressos.

Consideramos parcialmente confirmadas as seguintes hipóteses:

- O professor de Língua Portuguesa, ao trabalhar com linguagens, acompanha as mudanças tecnológicas e as insere em suas aulas. 
Há variáveis quanto ao acompanhamento, inserção dos aparatos e estudo das linguagens comunicacionais em sala, os quais, em sua maioria, requisitam o seguimento docente das alterações ocorridas socialmente quanto ao uso dos dispositivos e gêneros do jornalismo e da publicidade, sobretudo do espaço digital. As principais variáveis são a disposição, disponibilidade e busca do educador em verificar as necessidades de sua turma e as possibilidades materiais apresentadas pela unidade escolar, respeitando, principalmente, as temáticas do universo adolescente. Nas entrevistas, os professores de Língua Portuguesa revelam perceber a inovação como uma das exigências sociais contemporâneas, o que pressupõe, em atividades com gêneros como notícia, entrevista, reportagem, cartum e caricatura, a abordagem destas mensagens pelos meios audiovisuais; entretanto, o tratamento dos referidos textos não garante o uso dos mecanismos tecnológicos em sala.

- A disponibilização dos "cadernos de apoio pedagógico" da rede municipal apenas no ambiente virtual (Portal Pedagógico), a partir do $2^{\circ}$ semestre de 2011, é compreendida como uma estratégia importante para a prática pedagógica dos docentes de Língua Portuguesa quanto à utilização das linguagens da comunicação nos anos finais do Ensino Fundamental.

A princípio, a retirada de circulação do material impresso "cadernos de apoio pedagógico" provocou ou até mesmo "obrigou" a reestruturação das estratégias dos professores do ciclo final do Ensino Fundamental ( $8^{\circ}$ e $9^{\circ}$ anos), bem como mudanças de comportamento de ambos os lados, afinal, os adolescentes demonstravam não valorizarem tanto o material, de acordo com relatos da Secretaria de Educação. Institucionalizado há seis anos, o material, que tinha o escopo de ser apenas mais um auxílio para os docentes, foi incorporado como uma verdadeira apostila. No final de 2011, a inexistência desse conteúdo impresso, disponível apenas no ambiente virtual, dificultou consideravelmente as atividades propostas, principalmente em relação a determinados gêneros textuais que utilizam a linguagem não verbal e abusam do uso de imagens. É o caso, por exemplo, dos publicitários. Em contrapartida, os educadores tiveram que buscar novas ações didáticas em seu cotidiano para abordar gêneros jornalísticos como os cartuns, que permaneceram no plano de ensino e pelos quais os alunos se sentem mais atraídos. Não percebemos uma dicotomia propriamente dita, mas uma angústia dos professores diante da necessidade de trabalhar diversificadamente com estes textos, e em decorrência da qual se sentem "obrigados" a modificar, estudar e até pedir auxílio aos instrutores de informática quanto ao manejo de alguns aparatos/suportes, com vistas a agradar estes jovens e melhorar a qualidade da apresentação das aulas. 
O fato é que não houve a impressão gráfica destes cadernos a todos os anos do Ensino Fundamental da rede de Barueri no $1^{\circ}$ semestre de 2012, o que causou bastante apreensão nos professores. Muitos recorreram aos livros didáticos disponíveis e outros permaneceram seguindo o material que já utilizavam.

Consideramos parcialmente rejeitada a seguinte hipótese:

- O professor de Língua Portuguesa, quanto à questão da recepção, considera o perfil dos alunos adolescentes de maneira homogênea, sem perceber que as novas tecnologias e linguagens interferem na recepção das mensagens e na constituição de sentidos.

De forma alguma os participantes da pesquisa consideram a recepção do aluno de maneira homogênea: eles percebem que a produção de sentidos é uma construção dependente do contexto e de elementos mediativos. O professor de Língua Portuguesa reconhece a existência de novas formas de conhecimento e que estas interferem no processo de aprendizagem dentro da escola. No entanto, não consideramos a hipótese totalmente rejeitada, porque muitos pesquisados, ao falarem da recepção fora da instituição escolar, demonstram uma análise unidirecional e homogênea do sentido, acreditando que a televisão tem impacto direto no jovem receptor, sem considerar as mediações que interferem na construção do significado.

Consideramos rejeitadas as seguintes hipóteses:

- O professor de Língua Portuguesa, ao utilizar o material de apoio pedagógico da rede municipal de Barueri distribuído aos alunos, não faz uso de alternativas quanto à aplicação de atividades de linguagens jornalística e publicitária em sala de aula.

Afirmar que o docente não faz opções por outros recursos pedagógicos no uso do jornalismo e publicidade em sala seria admitir que estes profissionais não desenvolveram opinião própria e análise crítica e, ainda, que são descontextualizados da realidade na qual estão inseridos. $\mathrm{O}$ fato ocorrido durante o percurso de nossa pesquisa - a retirada de circulação deste material - provocou, em grande parte dos educadores, a busca por outros materiais. Esta ação governamental provocou modificações no comportamento de muitos professores, que procuraram, sim, outras alternativas, incluindo recursos materiais e tecnológicos, para suprir 
esta ausência. Demonstraram certa acomodação ao uso do material como um manual de ensino junto aos alunos, considerando que sua elaboração foi de acordo com o plano de ensino da disciplina, o que também contribui para esta atitude de estagnação.

- A proposta de transferência do material pedagógico do suporte impresso para a tela é bem vista pelo professor de Língua Portuguesa, que percebe a mudança como necessária para o trabalho em sala de aula com os adolescentes.

Ainda em relação aos cadernos de apoio pedagógico, agora no espaço digital, não houve uma visão positiva dos professores por conta de questões estruturais de acesso a eles, em tempo real, pelos alunos. Na visão dos docentes, isto seria possível se as aulas dos alunos fossem no laboratório de informática. Outro fator a ser levado em conta é que a maioria dos professores justifica o uso de materiais impressos baseados na suposta necessidade concreta dos alunos, e não, em muitos casos, pelas dificuldades pessoais do próprio profissional no trato com as novas tecnologias com os gêneros do jornalismo e publicidade no espaço digital. 


\section{CONSIDERAÇÕES FINAIS}

Ao estabelecer um ponto final para a pesquisa, embora o método qualitativo abra um amplo campo de análises, consideramos que cumprimos os objetivos iniciais propostos. Verificamos de que forma os gêneros jornalísticos e publicitários são legitimados pelos docentes de Língua Portuguesa nos anos finais do Ensino Fundamental em Barueri.

Em relação ao jornalismo, identificamos que ele é predominante quanto aos textos comunicacionais em sala; da notícia ao editorial, são estudos propostos aos alunos de forma a direcionar a aprendizagem de suas estruturas, variando de acordo com a metodologia do profissional docente. Nas atividades em sala de aula, questões relacionadas a aspectos ideológicos e críticos destas mensagens parecem menos presentes, comparado as publicitárias, confirmando o que Eugênio Bucci afirma sobre a suposta neutralidade do discurso (tele) jornalístico. A assertiva é confirmada para maioria dos entrevistados, mas sofre alterações de acordo com o meio de comunicação escolhido. Por exemplo, se a mensagem for veiculada pela televisão, possui um tratamento diferenciado quando comparado ao impresso, rádio ou internet. Apesar da última estar presente o tempo todo nos discursos e ações cotidianas dos discentes, a TV ainda é prevalente. Conquanto haja desconfiança por parte dos professores em relação ao impacto dos conteúdos televisivos sobre os educandos, com maior ênfase aos gêneros da publicidade, concomitantemente há também disposição para o trabalho com seus textos.

Quanto às mensagens publicitárias, há mais estudos comparativos sobre seu caráter persuasivo, sedutor e acerca do consumo, principalmente com os discentes dos $9^{\circ}$ anos. Nas comparações entre as linguagens, a publicidade parece ser introduzida nas atividades para além do simples estudo estrutural, pois, em sua utilização, são acoplados outros recursos que permitem maior amplitude de sua dimensão, e até a inserção de aparatos tecnológicos por conta disto.

Apesar das necessidades apresentadas, verificamos que a cultura escrita continua hegemônica na preferência docente para ações pedagógicas com a comunicação, orientados pelos planos de ensino e objetivos da disciplina; entretanto, apesar desta predominância, há concorrência com as outras linguagens (audiovisual, digital) neste espaço, inseridas em larga escala pelos alunos.

Percebemos ao longo da investigação que, entre os meios, a preferência é pelos assuntos da TV para a escolha de temas, debates e comentários em aula, fato ratificado pelos 
educadores. Neste ínterim, houve demonstração do entendimento da função de mediadores deste processo de ensino e aprendizagem pela maioria dos sujeitos pesquisados, nas questões referentes à manipulação, entretenimento e ideologias; contudo, atribuem parcela de culpa aos meios. Por isto, demonstraram, muitas vezes, uma visão unidirecional em relação à comunicação, o entendimento de um receptor passivo.

No âmbito digital, observamos um discurso pedagógico que valoriza a sua importância no cotidiano de suas práticas, mas, nos momentos em que acontece a aplicação destas ações, ainda existem desconfianças, atribuídas, pelos educadores, à falta de orientação sobre a melhor forma de utilizá-los. Percebemos que esta lacuna é, em parte, responsável pelos desconfortos nesta relação, pois, na maioria dos depoimentos, observamos um educando bem articulado com este mundo, ao ponto de explicar detalhadamente ao próprio mestre a função destas mensagens.

A idade dos discentes (média de 13 a 15 anos) provoca uma dicotomia no comportamento dos professores: de um lado, eles se veem obrigados a modificar sua prática e a se apropriar mais dos dispositivos, meios comunicacionais e recursos tecnológicos e, de outro, mostram-se inseguros na tentativa de agradar um público cujas características comportamentais e facilidades no manuseio dos aparatos acabam gerando conflitos e resistências.

Estes jovens da chamada geração Z (indivíduos que nasceram a partir de 1989) se mostram exigentes, individualistas, consumistas e absolutamente digitais. Soma-se a isso o conjunto de características próprias da faixa etária, entre elas a busca pela independência e a forte necessidade de ter a referência dos colegas de grupo. Ressaltamos que este perfil foi percebido nos diálogos com os alunos da rede educacional de Barueri. Apesar de todas essas evoluções, eles ainda não são adultos, são dependentes de orientação docente no ambiente educacional e esbarram em várias dificuldades por terem experiências interativas muito constantes, se comparados à geração de educadores pesquisados com média etária de 39 a 49 anos de idade (10 a 15 anos de magistério).

Diante destas implicações, lembramos-nos de Moacir Gadotti (2003), sobre o papel do educador quanto à procura pelo "sentido", de um caminho não percorrido, portanto, de um sonho, utopia, do desejo de atingir os objetivos propostos. Entretanto, a realidade é diferente e requer deste profissional um esforço para se tornar o que o autor chama de organizador de aprendizagens. Gadotti reitera a ideia de que o êxito no ensino não depende tanto do conhecimento docente, mas de criar espaços para que a aprendizagem ocorra. $\mathrm{Na}$ visão do 
pedagogo, estes locais devem ser sedutores, atraentes, motivadores, conter emoção, como dizia Paulo Freire, para que os jovens possam realizar a sua própria leitura de mundo.

$\mathrm{Na}$ relação com as tecnologias, encontramos o perigo do distanciamento, a frieza, a falta de sensibilidade e afetividade no relacionamento humano. Com o termo "reencantar", utilizado por Hugo Assmann (2000), com conotação freiriana, ao se referir ao processo educacional, vem à tona a ideia de colocar ternura e considerar a relação homem-máquina com uma visão humanista, evitando os perigos de um determinismo tecnológico.

É a tecnicidade de que trata Jésus Martín-Barbero (2009) - como o autor enfatiza, em frente à tela do computador não estamos apenas diante de uma máquina, mas estabelecemos uma relação diferente de todas as anteriores, vínculos entre informações e cérebro por meio da linguagem sonora, visual, escrita e multimídia.

O lugar das tecnologias é um dos desafios a serem enfrentados na inter-relação entre comunicação e educação que deve ser pensado com vistas a favorecer emancipação dos alunos, como apontado por Adilson Citelli (2010b). Ainda no quesito tecnológico, outro item a ser considerado é a dimensão discursiva quanto aos textos (não) verbais, o hipertexto, pois permite a construção de ideias, valores e conceitos que circulam pelos suportes comunicacionais, circulação esta não tão adequada do ponto de vista pedagógico, mas que resultam em novas leituras e interpretações das mensagens, como citado nos depoimentos dos alunos.

Constatamos, nas entrevistas docentes, a existência de dois projetos de escolas municipais envolvendo a comunidade local e escolar que estão dentro das chamadas ações educomunicativas: o primeiro é o portal desenvolvido na EMEF Nestor de Camargo, de período integral; o outro é realizado com a Revista Época (Editora Globo) por meio de estudos do gênero reportagem, em uma escola compartilhada a EMEF Suzete da Costa e Silva. As duas atividades, por si só, proporcionariam outras investigações pertinentes ao campo da Educomunicação, como proposto pelo professor Ismar de Oliveira Soares. Elas mobilizam todo o corpo da escola, direta e indiretamente, e atingem o entorno da instituição, promovendo ações benéficas de expressão do conhecimento por meio das linguagens jornalísticas. Assim, auxiliam nas habilidades de leitura e escrita e promovem uma verdadeira gestão comunicativa, oferecendo aos docentes e discentes a oportunidade de atuarem socialmente.

Os educadores pesquisados mostraram disponibilidade para instituir atividades que possibilitem novas estratégias educomunicacionais, já que são unânimes ao apontar que as linguagens (casos do jornalismo e publicidade) aproximam os alunos e ajudam a estabelecer 
um processo comunicativo em sala de aula. No entanto, também foi apontada por eles a necessidade de uma formação docente continuada que os oriente sobre o uso dos circuitos midiáticos, conforme apontado por Citelli (2010).

O sistema educacional, as propostas curriculares, os planos de ensino, os materiais pedagógicos, bem como a palavra de autoridade institucional, compõem os jogos discursivos existentes em torno da prática docente e perpetuam formatos procedimentais que ratificam a "vontade de verdade", conceito de Michel Foucault, por meio de seleção, controle e redistribuição de determinadas ações.

Dando sequência à ideia foucaultiana, no que se refere aos currículos (entendidos como dispositivos) dos cursos de graduação de Letras, os docentes revelaram sentir a ausência de disciplinas com objetivos práticos e a necessidade de ações concretas que viabilizem a utilização dos meios e das tecnologias - sobretudo quanto aos textos midiáticos digitais. O controle de caráter disciplinar que conserva discursivamente o que pode ser realizado ou não, o que está incluso no planejamento, encontra-se presente nos depoimentos dos professores pesquisados.

Outro item que provoca interferência na rede organizacional e nas ações pedagógicas em sala é a infraestrutura das unidades escolares municipais. Durante a pesquisa, identificamos quatro modelos de escolas de Ensino Fundamental: 1) a de período integral; 2) a compartilhada; 3) a normal; 4) a chamada EMEIEF (Escola Municipal de Educação Infantil e Ensino Fundamental). Nas quatro integrais, os alunos permanecem 8 horas por dia. Elas apresentam diversos recursos materiais e tecnológicos, além de currículo diversificado, que contém duas aulas de orientação à leitura (OLP); duas delas possuem piscinas semiolímpicas. Constatamos, inclusive, que uma destas escolas é a que desenvolve um dos projetos citados acima, organizado pelos professores de Língua Portuguesa e informática junto aos alunos dos anos finais.

Em outro extremo, as chamadas unidades compartilhadas (município e estado) apresentam mais dificuldades de acesso aos espaços e suportes que contribuiriam para a prática dos professores, o que não invalida a aplicação dos textos comunicacionais em sala, mas dificulta os caminhos pedagógicos para o seu tratamento neste espaço.

Dentro do contexto, o município de Barueri, pelos índices verificados, apresenta condições (educacionais, culturais e econômicas) para implementar ações voltadas à interface comunicação e educação. Neste sentido, a investigação apontou algumas indicações, tais como: a melhoria dos cursos de formação docente continuada, reflexões sobre a estrutura 
curricular e orientações didáticas para o uso dos gêneros jornalísticos e publicitários da esfera digital, entre outras.

Para além das contradições físicas estruturais e metodológicas, da instituição governamental até a escolar parece que o mundo editado pelos meios comunicacionais se sobrepõem à dita realidade - não basta reduzirmos a aspectos quantitativos o tratamento educacional. O impasse já colocado por Edgar Morin (2002) é vivenciado na prática: não se pode reformar a instituição sem uma prévia reforma das mentes, mas não se podem reformar as mentes sem uma prévia reforma das instituições. Para o francês, a noção de um ensino educativo significa uma educação que favoreça o entendimento de uma cultura focada na condição para o pensar aberto e livre, e não no caráter transmissivo, aproximada à concepção brasileira freiriana para a busca do aprimoramento das capacidades intelectuais à autonomia do pensamento.

Nas telas da vida real municipal, temos desde os desacertos de valores societários e culturais interferindo no ambiente da sala de aula; das condições econômicas relativamente consideráveis, gerando meandros desiguais dentro do mesmo sistema; até composições físicas de primeiro mundo que permitem a execução de projetos com os circuitos midiáticos, por meio do uso de textos jornalísticos e publicitários nos mais variados suportes, com os recursos dos aparatos tecnológicos, o que possibilita ações cidadãs educomunicativas.

Como já exposto, no mesmo contexto observamos a falta de espaço e recursos que possibilitem a melhoria deste processo de interface entre Comunicação e Educação. É notória a existência de paradoxos que aproximam e distanciam a articulação dos fatores determinantes para a implantação de práticas didáticas com os textos comunicacionais em sala de aula. Os docentes intitulados de especialistas da língua ora se angustiam por não se libertar de um modo de ensinar que não preza a visão autônoma, ora se assustam ao perceber que os discentes já trilham seus caminhos de maneira a não depender deles.

As condições financeiras que direcionam os indicadores classificatórios do município não garantem a inexistência de dificuldades; estas são reais, quer estejam ligadas a aspectos culturais, econômicos, sócio-históricos ou de recursos humanos ou ainda à falta de formação (leia-se graduação e continuada) adequada à atitude pedagógica, que se torna um quesito essencial para a superação dos obstáculos referentes à inserção destes docentes na condição comunicativa do século XXI. O contexto atual delega a estes profissionais não apenas a mera transmissão de informações, porque isto os meios de comunicação fazem bem, o que se faz urgente é o famoso ensinar a viver (Morin) nesta sociedade comunicacional, e isto requer mais do que cifras monetárias, prédios luxuosos, espaços interessantes; isto exige atitudes, ou 
melhor, ajustes de projetos: desde políticas públicas que priorizem as necessidades desta época e que proporcionem condições dignas de vida, perpassando a adequação da estrutura educacional a este modelo social vigente, a reestruturação curricular, com amplas discussões entre os docentes, gestores e dirigentes acerca de cada área do conhecimento e contextos, além da consideração das necessidades destas jovens gerações discentes, às quais estão direcionadas expectativas de progresso e evolução, em todos os aspectos e esferas municipal, estadual e nacional.

Evocamos Theodor Adorno (1995) para quem a exigência de emancipação parece ser evidente numa democracia e acrescentamos, por meio desta dissertação: ela é imprescindível para este modelo societário no qual a comunicação possui função central. 


\section{REFERÊNCIAS BIBLIOGRÁFICAS}

ADORNO, Theodor; HORKHEIMER, Max. Dialética do Esclarecimento. Rio de Janeiro: Zahar, 1985.

. Educação e Emancipação. 4. ed. Rio de Janeiro: Paz e Terra, 1995.

A indústria cultural. In COHN, Gabriel (org.). Comunicação e Indústria Cultural. São Paulo: T. A. Queiroz, 1987.

AGAMBEN, Giorgio. O que é o contemporâneo? E outros ensaios. Santa Catarina: Argos, 2009.

ASSMANN, Hugo. A metamorfose do aprender na sociedade da informação. Ciência da Informação. Brasília, v. 29, nº 2, p. 7-15, maio/ago.2000.

BACCEGA, Maria Aparecida. Comunicação e linguagem: discurso e ciência. São Paulo: Moderna, 1998.

histórica. São Paulo: Paulinas, 2011.

Comunicação/Educação e a construção de nova variável

BAKHTIN, Mikhail. Marxismo e Filosofia da Linguagem. São Paulo: Hucitec, 1992.

Estética da Criação Verbal. São Paulo: Martins Fontes, 2000.

BARUERI, Prefeitura Municipal. Material Didático do Ensino Fundamental. Caderno de Apoio. $9^{\circ}$ ano $/ 8^{\mathrm{a}}$ série: $1^{\mathrm{o}}$ semestre 2011. Barueri: Editora Traço, 2010.

Material Didático do Ensino Fundamental. Caderno de Apoio. $8^{\circ}$ ano $/ 7^{\mathrm{a}}$ série: $1^{\mathrm{o}}$ semestre 2011. Barueri: Editora Traço, 2010.

Plano de Referência para a educação básica: Língua

Portuguesa. Barueri: Editora Traço, 2010.

BAUDRILLARD, Jean. A sociedade de consumo. Lisboa: Edições 70, 1991. 
BELTRÃO, Luiz. 1992. Iniciação à filosofia do jornalismo. São Paulo: Edusp, 1992.

BRANDÃO, Helena Nagamine (coord.). Gêneros do discurso na escola: mito, conto, cordel, discurso político e divulgação científica. 4. ed. São Paulo: Cortez, 2003.

BRASIL, Secretaria de Educação Fundamental. Parâmetros Curriculares Nacionais: terceiro e quarto ciclos do Ensino Fundamental Língua Portuguesa. Brasília: MEC/SEF, 1998.

BENJAMIN, Walter. Magia e técnica, arte e política. São Paulo: Brasiliense, 1987.

BOLLE, Willi. A ideia de formação na modernidade. In: GHIRALDELLI JÚNIOR, Paulo (org.). Infância, escola e modernidade. São Paulo: Cortez, 1997.

BOURDIEU, Pierre. A profissão de sociólogo. Petrópolis: Vozes, 1999.

BUCCI, Eugênio; KEHL, Maria Rita. Videologias: ensaios sobre a televisão. São Paulo: Boitempo, 2004.

CARVALHO, Nelly. Publicidade: a linguagem da sedução. São Paulo: Ática, 1996.

CASTELLS, Manuel. A galáxia da internet: reflexões sobre a internet, os negócios e a sociedade. Rio de Janeiro: Jorge Zahar, 2003.

Entrevista concedida ao programa Europa Abierta, da rádio e TV pública espanhola em jan. de 2012. Disponível em: <http://www.outraspalavras.net/2012/01/17/castells-debate-os-dilemas-da-internet/>. Acesso em 10 de jun. 2012.

CITELLI, Adilson Odair (coord.). Aprender e ensinar com textos não escolares. São Paulo: Cortez, 1997. 3 v.

Paulo: Senac, 2004a.

. Educação e Comunicação: a linguagem em movimento. São . Linguagem e Persuasão. São Paulo: Ática, 2004b. 
2006.

Palavras, meios de comunicação e educação. São Paulo: Cortez,

. Linguagens da comunicação e desafios educacionais: o problema da formação dos jovens professores. Revista Comunicação e Educação. São Paulo: CCCAECA-USP. Paulinas, ano XV, ${ }^{0} 1$, jan./abr. 2010a.

Comunicação e educação: convergências educomunicativas.

Revista Comunicação, mídia e consumo. São Paulo, v. 7, nº 19, p. 67-85, jul. 2010 b.

- Ensino a distância na perspectiva dos diálogos com a comunicação. Revista Comunicação, mídia e consumo. São Paulo, v. 8, nº 22, p. 187-209, jul. 2011.

CHARAUDEAU, Patrick. Le discours propagandiste. Le Français dans le Monde. Paris, Hachette/Larousse, nº 182,jan./1984, p.99-103.

CHAUÍ, Marilena. O discurso competente. In: Cultura e democracia. O discurso competente e outras falas. São Paulo: Moderna, 1981.

COSTA, Belarmino César Guimarães. Comunicação e Educação na era digital: reflexões sobre estética e virtualização. Revista Comunicação, mídia e consumo. São Paulo, v. 7, nº 19 , p. 87-103, jul. 2010.

DOLZ, Joaquim; SCHNEUWLY, Bernard. Gêneros orais e escritos na escola. Campinas: Mercado das Letras, 2004.

ESCOSTEGUY, Ana Carolina. Os Estudos Culturais. In HOHLFELDT, Antonio; MARTINHO, Luiz C.; FRANÇA,Vera Veiga. Teorias da comunicação. 3. ed. Vozes: Petrópolis, 2001.

FARIA, Maria Alice de O. Como usar o jornal em sala de aula. 11. ed. São Paulo: Contexto, 2011.

FISCHER, Rosa Maria B. O dispositivo pedagógico da mídia: modos de educar na (e pela) TV. Revista Educação e Pesquisa. São Paulo: v.28, nº 1, p.151-162, jan./jun. 2002.

Mídia, máquinas de imagens e práticas pedagógicas. Revista Brasileira de Educação. Rio de Janeiro, v.12, n 35, maio/ago. 2007. 
FONTENELLE, Isleide Arruda. O nome da marca: McDonald's, fetichismo e cultura descartável. São Paulo: Boitempo, 2002.

FREIRE, Paulo. Pedagogia do Oprimido. Rio de Janeiro: Paz e Vida, 1986.

Pedagogia da Esperança: um reencontro com a pedagogia do oprimido. Rio de Janeiro: Paz e Terra, 1992.

Pedagogia da autonomia: saberes necessários à prática educativa. São Paulo: Paz e Terra, 1996.

A importância do ato de ler em três artigos que se completam. 9. ed. São Paulo: Cortez, 2000.

FOUCAULT, Michel. A ordem do discurso. 16. ed. São Paulo: Loyola, 2008.

FUNDAÇÃO VICTOR CIVITA. Estudos e Pesquisas Educacionais, n ${ }^{0}$ 1. São Paulo, maio 2010.

GADOTTI, Moacir. Boniteza de um sonho: ensinar e aprender com sentido. Novo Hamburgo: Fevale, 2003.

GIDDENS, Anthony. As consequências da modernidade. São Paulo: Ed. Unesp, 1991.

GOHN, Maria da Glória. Educação não formal e cultura política. São Paulo: Cortez, 2008.

HABERMAS, Jürgen. Para a reconstrução do materialismo histórico. São Paulo: Brasiliense, 1983.

HALL, Stuart. Cultural Studies: two paradigms. In: STOREY, John (org.). What is Cultural Studies? A Reader, Londres: Arnold, 1996.

Editora, 1997.

A identidade cultural na pós-modernidade. 5 ed. Rio de Janeiro: DPS A 
HERNÁNDEZ, Fernando. Transgressão e mudança na educação: os projetos de trabalho. Porto Alegre: Artmed, 1998.

Alegre: Artmed, 2000.

Cultura visual, mudança educativa e projeto de trabalho. Porto

HOGGART, Richard. As utilizações da cultura: aspectos da vida cultural da classe trabalhadora. Lisboa: Editora Presença, 1973. 1 v.

JENKINS, Henry. Cultura da Convergência. São Paulo: Aleph, 2009.

LAGE, Nilson. Linguagem Jornalística. 7. ed. São Paulo: Ática, 2003.

LÉVY, Pierre. As tecnologias da inteligência:O Futuro do Pensamento na Era da Informática. Rio de Janeiro: Editora 34, 1993.

LIPOVETSKY, Gilles. Sedução, publicidade e pós-modernidade. Revista Famecos. Porto Alegre, $n^{\circ}$ 12. jun. 2000. Semestral.

LOPES, Maria Immacolata Vassallo de. Pesquisa de Comunicação. Revista Brasileira de Ciências da Comunicação. São Paulo: Volume XXVII, nº 1, jan./jun. 2004.

Loyola, 2005.

Pesquisa em Comunicação. 7 ed. São Paulo:

MARCONDES FILHO, Ciro. O capital da notícia: jornalismo como produção social de segunda natureza. São Paulo: Ática, 1986.

MARCUSCHI, Luiz Antônio; XAVIER, Antônio Carlos dos Santos (orgs.). Hipertexto e Gêneros Digitais. Rio de Janeiro: Lucerna, 2005.

MARTÍN-BARBERO, Jesús. Heredando El futuro. Pensar la educación desde la comunicación. Revista Nómadas. Bogotá: Fundación Universidad Central, 1996.

2. ed. Rio de Janeiro: UFRJ, 1997.

Dos meios às mediações: comunicação, cultura e hegemonia. 
América Latina e os anos recentes: o estudo da recepção em comunicação social. In: SOUSA, Mauro Wilton (org.). Sujeito, o lado oculto do receptor. São Paulo: Brasiliense, 2002.

Tecnicidades, identidades, alteridades: mudanças e opacidades da comunicação no novo século. In: MORAES, Dênis de (org.). Sociedade Midiatizada. Rio de Janeiro: Mauad, 2006.

Uma aventura epistemológica. Revista Matrizes. Revista do Programa de Pós-Graduação em Ciências da Comunicação da Universidade de São Paulo. São Paulo: Paulus. Ano 2. n 2. Primeiro semestre de 2009. p.151-152.

; REY, Germán. Os exercícios do ver: hegemonia audiovisual e ficção televisiva. São Paulo: Senac, 2001.

MELO, José Marques de. Jornalismo Opinativo: gêneros opinativos no jornalismo brasileiro. Campos do Jordão: Mantiqueira, 2003.

; ASSIS, Francisco de (org.). Gêneros Jornalísticos no Brasil. São Bernardo do Campo, Umesp, 2010.

MENDONÇA, Maria Luiza Martins. Comunicação e Cultura: um novo olhar. In SOUSA, Mauro W. (org.). Recepção mediática e espaço público: novos olhares. São Paulo: Paulinas, 2006.

METZKER, Gabriela Felippe Rodrigues. A formação do professor na Universidade para a inter-relação comunicaçãoleducação. Dissertação (Mestrado em Ciências da Comunicação). São Paulo: Universidade de São Paulo, Escola de Comunicações e Artes, São Paulo, 2010.

MORAN, José M. A educação que desejamos, novos desafios e como chegar lá. São Paulo: Papirus, 2007.

MORIN, Edgar. A cabeça bem-feita: repensar a reforma, reformar o pensamento. 7. ed. Rio de Janeiro: Bertrand Brasil, 2002.

NAGAMINI, Eliana. O discurso da publicidade no contexto escolar: a construção de pequenos enredos. In: CITELLI, Adilson Odair (coord.). Outras linguagens na escola: publicidade, cinema, TV, rádio, jogos, informática. Coleção aprender e ensinar com textos, v. 6. São Paulo: Cortez, 2000. 
OROZCO GÓMEZ, Guillermo. Recepción televisiva y mediaciones: la construción deestrategias por la audiencia. In: . (coord.). Televidencia: perspectivas para el analisis de los procesos de recepcion televisiva (Cuadernos de comunicacion y practicas sociales). Cidade do México: Iberoamericana, 1994.

Comunicação Social e mudança tecnológica: um cenário de múltiplos desordenamentos. In: MORAES, Dênis de (org). A sociedade midiatizada. Rio de Janeiro: Mauad, 2006.

Entre pantallas: nuevos roles comunicativos de las audiencias.

Curitiba: Congresso da Intercom, 2009.

PENTEADO, Heloísa Dupas. Televisão e Escola: Conflito ou Cooperação. São Paulo: Cortez, 1991.

PERRENOUD, Philippe. Construir as competências desde a escola. Porto Alegre: Artmed, 1999.

As competências para ensinar no século XXI: a formação dos professores e o desafio da avaliação. Porto Alegre: Artmed, 2002.

PRENSKY, Marc. Don't bother me, mom. I'm learning! How computer and video games are preparing your kids for 21st century success and how you can help! .St.Paul, Minessota: Paragon House, 2006.

. O aluno virou o especialista. Entrevista Revista Época. Editora Globo, edição 634, julho 2010. Disponível em: <www.revistaepoca.globo.com/Revista/Epoca/0,,EMI153918-15224,00-

MARC+PRENSKY+O+ALUNO+VIROU+O+ESPECIALISTA.html>. Acesso em 14 de jun. 2012.

RANCIÈRE, Jacques. $O$ mestre ignorante: cinco lições sobre a emancipação intelectual. Belo Horizonte: Autêntica, 2002.

RÜDIGER, Francisco. A escola de Frankfurt. In: HOHLFELDT, Antonio; MARTINO, Luiz C.; FRANÇA, Vera Veiga. Teorias da comunicação. 3. ed. Vozes: Petrópolis, 2001.

SANTOS, Boaventura Sousa. A gramática do tempo: para uma nova cultura política do tempo. São Paulo: Cortez, 2006. 4 v. 
SARESP, Sistema de Avaliação do Rendimento Escolar do Estado de São Paulo. Matrizes de Referência para Avaliação. Documento básico/Secretaria da Educação. Coordenação Geral: Maria Inês Fini. São Paulo: SEE, 2009.

SARLO, Beatriz. Cenas da vida pós-moderna - intelectuais, arte e vídeo-cultura na Argentina. Rio de Janeiro: UFRJ, 1997.

SNYDERS, Georges. Alunos felizes: reflexões sobre a alegria na escola. Rio de Janeiro: Paz e Terra, 1991.

SOARES, Ismar de Oliveira. Educomunicação: o conceito, o profissional, a aplicação. São Paulo: Paulinas, 2011.

SOUSA, Mauro Wilton de. Comunicação e Educação: entre meios e mediações. Cadernos de Pesquisa, n 106, p. 9-25, mar./1999.

Paulo: Paulinas, 2006. . (org.). Recepção mediática e espaço público: novos olhares. São

THIOLLENT, Michel J. M. Crítica metodológica, investigação social e enquete operária. São Paulo: Polis, 1980.

THOMPSON, Edward Palmer. A formação da classe operária inglesa. Rio de Janeiro: Paz e Terra, 1987.

THOMPSON, John Brookshire. A Mídia e a Modernidade: uma teoria social da mídia. Rio de Janeiro: Petrópolis, 2011.

VATTIMO, Gianni. A sociedade transparente. Lisboa: Ed. Relógio D’água, 1992.

WILLIAMS, Raymond. Cultura. Rio de Janeiro: Paz e Terra, 1992.

WITTGENSTEIN, Ludwig. Investigações Filosóficas. Bragança Paulista: Editora Universitária, São Francisco; Petrópolis: Vozes, 2005. 


\section{ANEXOS}

\section{ANEXO A - Plano de Ensino do $8^{\circ}$ ano}

PLANO DE ENSINO ANUAL

\begin{tabular}{|l|l|}
\hline Disciplina & Língua Portuguesa \\
\hline Professores & \\
\hline Ano/ Série & 8으o/7a Série \\
\hline Carga Horária & \\
\hline Ano letivo & \\
\hline
\end{tabular}

Justificativa da disciplina

Ementa 


\section{LÍNGUA PORTUGUESA 8 ANO 1 BIMESTRE}

\begin{tabular}{|c|c|c|}
\hline $\begin{array}{l}\text { Bloco de } \\
\text { conteúdo }\end{array}$ & Habilidades & Conteúdos \\
\hline 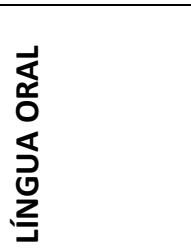 & $\begin{array}{l}\text { 1.1 Ler e comparar textos para conclusões e exposições de ideias. } \\
\text { 1.2 Analisar e inferir informações nos textos para troca de opiniões. } \\
\text { 1.3 Identificar elementos que caracterizam e diferenciam os gêneros. } \\
\begin{array}{c}\text { Tirar conclusões e fazer comentários a partir de } \\
\text { dados apresentados. }\end{array}\end{array}$ & $\begin{array}{l}\text { l. Notícias, entrevistas, reportagens, gráficos } \\
\text { e tabelas. }\end{array}$ \\
\hline \multirow{4}{*}{ 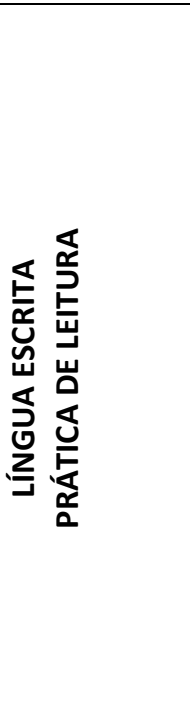 } & $\begin{array}{l}\text { 2.1 Reconhecer traços característicos do gênero e da estrutura notícia. } \\
\text { 2.2 Reconhecer diferenças e semelhanças entre gêneros da mesma } \\
\text { tipologia. } \\
2.3 \text { Identificar valores culturais e sociais em notícias de jornais. } \\
\text { 2.4 Analisar e comparar diferentes notícias sobre o mesmo assunto em } \\
\text { diferentes suportes de circulação. }\end{array}$ & 2. Notícias de diferentes revistas e jornais. \\
\hline & $\begin{array}{l}\text { 3.1 Reconhecer traços característicos do gênero entrevista. } \\
\text { 3.2 Estabelecer relações entre o texto e os conhecimentos prévios. }\end{array}$ & 3. Entrevistas de diferentes revistas e jornais. \\
\hline & $\begin{array}{l}\text { 4.1 Reconhecer elementos organizacionais e estruturais característicos do } \\
\text { gênero. } \\
4.2 \text { Identificar diferentes suportes de circulação de uma mesma reportagem. } \\
4.3 \text { Compreender critérios de organização das informações distribuídas em } \\
\text { parágrafos. } \\
\text { 4.4 Diferenciar os gêneros notícia, entrevista e reportagem e suas } \\
\text { estruturas. }\end{array}$ & 4. Reportagens. \\
\hline & $\begin{array}{l}\text { 5.1 Reconhecer informações a partir de gráficos e tabelas. } \\
5.2 \text { Tirar conclusões de dados parciais a partir de dados observados e } \\
\text { analisados em pesquisas. }\end{array}$ & 5. Gráficos e tabelas. \\
\hline \multirow{2}{*}{ 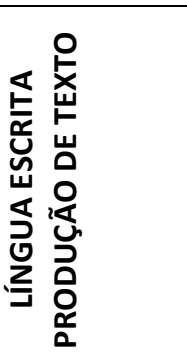 } & $\begin{array}{l}\text { 6.1 Construir tabelas e gráficos a partir de informações coletadas. } \\
\text { 6.2 Transformar dados em textos coerentes e coesos. }\end{array}$ & 6. Construção de gráficos e tabelas. \\
\hline & $\begin{array}{l}\text { 7.1 Produzir texto fazendo uso dos mecanismos de coerência e coesão. } \\
\text { 7.2 Escrever parágrafos organizados, utilizando conhecimentos adquiridos } \\
\text { de acordo com o contexto e a situação de comunicação. } \\
\text { 7.3 Revisar e reescrever o texto de acordo com os conteúdos linguísticos } \\
\text { estudados. }\end{array}$ & 7. Notícias, entrevistas e reportagens. \\
\hline \multirow{5}{*}{ 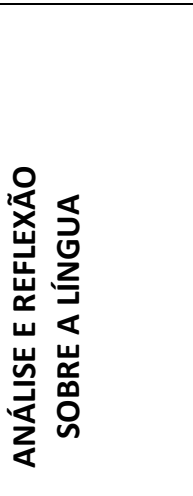 } & 8.1 Utilizar corretamente o hífen nas palavras compostas. & 8. Fonética - uso do hífen. \\
\hline & $\begin{array}{l}\text { 9.1 Revisar os conceitos gerais das classes gramaticais: verbo, substantivo, } \\
\text { adjetivo, numeral, pronome, preposição, interjeição e artigo. }\end{array}$ & $\begin{array}{l}\text { 9. Morfologia - revisão das classes gramaticais - } \\
\text { verbo, substantivo, adjetivo, numeral, pronome, } \\
\text { preposição, interjeição e artigo. }\end{array}$ \\
\hline & $\begin{array}{l}\text { 10.1 Identificar o sujeito da oração e sua relação de sentido com o } \\
\text { predicado. } \\
10.2 \text { Identificar os verbos de ligação e sua função na oração. } \\
\text { 10.3 Reconhecer os tipos de predicado. } \\
\text { 10.4 Reconhecer e estabelecer relações entre o predicativo do sujeito e o } \\
\text { sujeito da oração. }\end{array}$ & $\begin{array}{l}\text { 10. Sintaxe - sujeito - conceito geral e tipos de sujeito; } \\
\text { verbo de ligação; predicado - conceito geral e tipos de } \\
\text { predicado; predicativo do sujeito. }\end{array}$ \\
\hline & 11.1 Grafar corretamente as palavras com sons iguais ou parecidos. & $\begin{array}{l}\text { 11. Ortografia - uso de U e L; C, Ç e SS; E e I; Z e S; U } \\
\text { e O; X. }\end{array}$ \\
\hline & 12.1 Revisar e reescrever textos. & 12. Revisão e reescrita de textos. \\
\hline
\end{tabular}




\section{LÍNGUA PORTUGUESA $8 \cong$ ANO 2 BIMESTRE}

\begin{tabular}{|c|c|c|}
\hline $\begin{array}{l}\text { Bloco de } \\
\text { conteúdo }\end{array}$ & Habilidades & Conteúdos \\
\hline \multirow{2}{*}{ 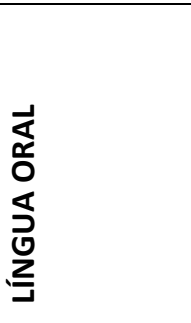 } & $\begin{array}{l}\text { 1.1 Identificar em textos de jornais e revistas a função social. } \\
\text { 1.2 Desenvolver o senso crítico e expor o seu ponto de vista. } \\
\text { 1.3 Comparar textos diferentes e comentar sobre os argumentos } \\
\text { percebidos. } \\
\text { 1.4 Reconhecer as particularidades e estrutura dos gêneros. } \\
\text { 1.5 Comparar cartas argumentativas sobre um mesmo assunto em } \\
\text { diferentes veículos de comunicação. }\end{array}$ & $\begin{array}{l}\text { 1. Editorial e carta argumentativa - identificação do } \\
\text { suporte, do portador, do emissor e do destinatário; } \\
\text { contextualização do gênero; estrutura e } \\
\text { desenvolvimento da dissertação. }\end{array}$ \\
\hline & $\begin{array}{l}\text { 2.1 Expor seus pontos de vista embasados em argumentos e respeitar as } \\
\text { situações de interlocução e pontos de vista diferentes do seu. }\end{array}$ & 2. Debates. \\
\hline \multirow{2}{*}{ 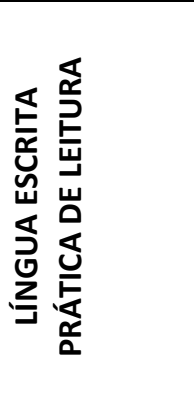 } & $\begin{array}{l}\text { 3.1 Reconhecer as particularidades e a estrutura do gênero. } \\
\text { 3.2 Identificar argumentos e elementos de persuasão presentes nos textos. } \\
\text { 3.3 Compreender a intencionalidade e o ponto de vista dos jornais e revistas } \\
\text { nos editoriais. }\end{array}$ & $\begin{array}{l}\text { 3. Editorial - identificação do emissor e destinatário; } \\
\text { contextualização do gênero; estrutura e } \\
\text { desenvolvimento da dissertação; estruturação dos } \\
\text { parágrafos; elementos de coesão e coerência. } \\
\text { 3. }\end{array}$ \\
\hline & $\begin{array}{l}\text { 4.1 Identificar o emissor e os possíveis destinatários das cartas } \\
\text { argumentativas. } \\
\text { 4.2 Estabelecer conexões entre os textos e os conhecimentos prévios. } \\
\text { 4.3 Identificar o tema e o assunto dos textos. } \\
\text { 4.4 Relacionar o gênero ao contexto de produção e suporte de circulação } \\
\text { original. }\end{array}$ & $\begin{array}{l}\text { 4. Carta argumentativa - estrutura e elementos } \\
\text { constituintes do gênero; elementos da comunicação: } \\
\text { emissor, destinatário, mensagem, canal, contexto. }\end{array}$ \\
\hline \multirow{2}{*}{ 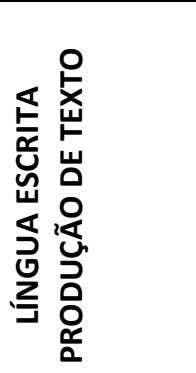 } & $\begin{array}{l}\text { 5.1 Planejar o texto a partir de informações e opiniões. } \\
\text { 5.2 Produzir o texto estruturando-o de acordo com o tema e o gênero. } \\
\text { 5.3 Utilizar argumentos para defender um ponto de vista. } \\
\text { 5.4 Organizar parágrafos coesos e coerentes. } \\
\text { 5.5 Revisar e reescrever o texto de acordo com a reflexão da língua. }\end{array}$ & $\begin{array}{l}\text { 5. Editorial - produção de texto com elementos } \\
\text { argumentativos e persuasivos. }\end{array}$ \\
\hline & $\begin{array}{l}\text { 6.1 Planejar o texto a partir de informações e opiniões. } \\
\text { 6.2 Escrever um texto curto estruturado de acordo com o tema e o gênero. } \\
\text { 6.3 Utilizar recursos linguísticos adequados para carta argumentativa. } \\
\text { 6.4 Revisar e reescrever o texto elaborado, antes da versão final. }\end{array}$ & $\begin{array}{l}\text { 6. Carta argumentativa - produção de carta } \\
\text { argumentativa de acordo com o canal de } \\
\text { comunicação. }\end{array}$ \\
\hline \multirow{4}{*}{ 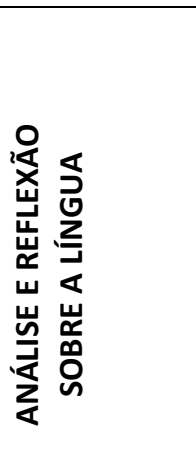 } & $\begin{array}{ll}\text { 7.1 } & \text { Reconhecer as desinências nominais e verbais. } \\
\text { 7.2 } & \text { Reconhecer e utilizar corretamente os verbos e suas flexões. } \\
\text { 7.3 } & \text { Reconhecer e utilizar corretamente as locuções verbais. }\end{array}$ & $\begin{array}{l}\text { 7. Morfologia - desinências nominais e verbais; } \\
\text { radical; vogal temática; verbos auxiliares; vozes } \\
\text { verbais; locução verbal; verbos: regulares, irregulares } \\
\text { e defectivos. }\end{array}$ \\
\hline & $\begin{array}{l}\text { 8.1 Identificar, classificar e diferenciar os termos integrantes da oração. } \\
8.2 \text { Reconhecer e estabelecer relação entre o predicativo do sujeito e o } \\
\text { sujeito. } \\
8.3 \text { Reconhecer e estabelecer relação entre o predicativo do objeto e o } \\
\text { objeto. }\end{array}$ & $\begin{array}{l}\text { 8. Sintaxe - termos integrantes da oração: objeto } \\
\text { direto, objeto indireto; objeto direto e indireto; } \\
\text { complemento nominal; complemento verbal; } \\
\text { predicativo do sujeito; predicativo do objeto. }\end{array}$ \\
\hline & $\begin{array}{l}\text { 9.1 Grafar corretamente as palavras de acordo com som ou escrita } \\
\text { parecidas. }\end{array}$ & $\begin{array}{l}\text { 9. Ortografia - uso da letra x com variação de } \\
\text { fonemas. }\end{array}$ \\
\hline & 10.1 Revisar e reescrever textos. & 10. Revisão e reescrita de textos. \\
\hline
\end{tabular}


Habilidades e Conteúdos: 3ำ Bimestre

\section{LÍNGUA PORTUGUESA 8 ANO 3 BIMESTRE}

\begin{tabular}{|c|c|c|}
\hline $\begin{array}{l}\text { Bloco de } \\
\text { conteúdo }\end{array}$ & Habilidades & Conteúdos \\
\hline \multirow{2}{*}{ 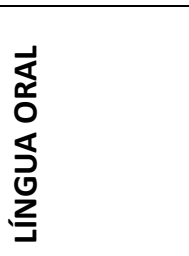 } & $\begin{array}{l}\text { 1.1 Perceber as características narrativas nas crônicas. } \\
\text { 1.2 Identificar o papel social das crônicas publicadas em jornais e revistas. } \\
\text { 1.3 Comparar situações ficcionais com situações reais e expor suas ideias. }\end{array}$ & $\begin{array}{l}\text { 1. Crônica - elementos e estrutura da narrativa; } \\
\text { crônicas jornalísticas; comparação com outros } \\
\text { gêneros de texto. }\end{array}$ \\
\hline & $\begin{array}{l}2.1 \text { Discutir sobre as situações vivenciadas pelos personagens dos filmes e } \\
\text { descrevê-los oralmente. }\end{array}$ & $\begin{array}{l}\text { 2. Filmes - análise de personagens, enredo, } \\
\text { descrição de tempo, espaço, narrador; descrição } \\
\text { objetiva e subjetiva; sinopse, resenha e resumo. }\end{array}$ \\
\hline \multirow{2}{*}{ 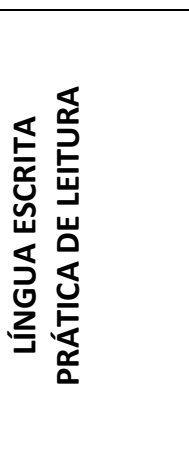 } & $\begin{array}{l}\text { 3.1 Identificar as características do gênero. } \\
\text { 3.2 Estabelecer relações entre o texto e os conhecimentos prévios. } \\
\text { 3.3 Inferir informações pressupostas ou subentendidas no texto (humorística } \\
\text { e argumentativa). } \\
\text { 3.4 Relacionar o texto ao seu contexto de produção e suporte de circulação } \\
\text { original. } \\
\text { 3.5 Identificar situações de ficção e realidade. } \\
\text { 3.6 Reconhecer estrutura da crônica e seu papel social. }\end{array}$ & $\begin{array}{l}\text { 3. Crônica - elementos e estrutura da narrativa; } \\
\text { crônicas jornalísticas; comparação com outros } \\
\text { gêneros de texto. }\end{array}$ \\
\hline & $\begin{array}{l}\text { 4.1 Comparar os elementos e a estrutura da narrativa em filmes com } \\
\text { situações da vida real. } \\
4.2 \text { Descrever de forma objetiva ou subjetiva de acordo com a } \\
\text { intencionalidade. }\end{array}$ & $\begin{array}{l}\text { 4. Filmes - análise de personagens, enredo, } \\
\text { descrição de tempo, espaço, narrador; descrição } \\
\text { objetiva e subjetiva; sinopse, resenha e resumo. }\end{array}$ \\
\hline 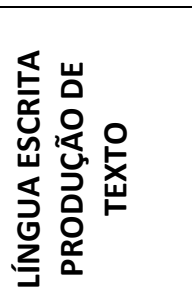 & $\begin{array}{l}\text { 5.1 Planejar o texto a partir de informações e opiniões. } \\
\text { 5.2 Planejar a resenha/ sinopse de filme para produzi-la levando em conta o } \\
\text { gênero, o contexto de produção e garantindo a relevância das partes para } \\
\text { representar o todo (tema). } \\
\text { 5.3 Produzir o texto estruturando-o de acordo com o gênero. } \\
\text { 5.4 Produzir resumo a partir da interpretação e compreensão do texto. } \\
\text { 5.5 Revisar e reescrever o texto elaborado, antes da versão final. }\end{array}$ & $\begin{array}{l}\text { 5. Sinopse e resenha de filmes; resumo de } \\
\text { crônicas; análise de personagens. }\end{array}$ \\
\hline \multirow{6}{*}{ 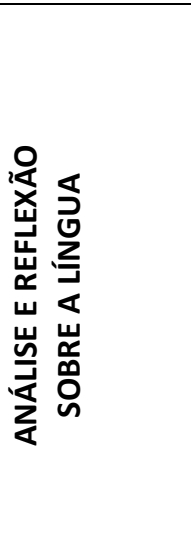 } & $\begin{array}{l}\text { 6.1 Reconhecer o uso do acento diferencial e utilizá-lo corretamente de } \\
\text { acordo com as regras do acordo ortográfico. }\end{array}$ & $\begin{array}{l}\text { 6. Fonética - regras do acordo ortográfico: acento } \\
\text { diferencial. }\end{array}$ \\
\hline & $\begin{array}{l}\text { 7.1 Compreender o uso adequado dos advérbios e locuções adverbiais e } \\
\text { suas funções nas orações, classificando-os corretamente. } \\
7.2 \text { Reconhecer a função do aposto e vocativo. }\end{array}$ & $\begin{array}{l}\text { 7. Morfologia - advérbio; locução adverbial; } \\
\text { aposto; vocativo. }\end{array}$ \\
\hline & $\begin{array}{l}\text { 8.1 Identificar e classificar os adjuntos adnominais e adverbiais. } \\
\text { 8.2 Identificar o agente da passiva: vozes verbais - ativa, passiva e reflexiva. } \\
\text { 8.3 Organizar as orações de acordo com a norma culta, observando as regras } \\
\text { de concordância verbal e nominal. }\end{array}$ & $\begin{array}{l}\text { 8. Sintaxe - adjunto adnominal; adjunto adverbial; } \\
\text { agente da passiva; concordância nominal e } \\
\text { concordância verbal. }\end{array}$ \\
\hline & $\begin{array}{l}\text { 9.1 Empregar corretamente palavras no sentido denotativo e conotativo de } \\
\text { acordo com o contexto. }\end{array}$ & 9. Semântica - conotação e denotação. \\
\hline & 10.1 Grafar corretamente palavras. & 10. Ortografia - uso de S, SS, SC, C e Ç. \\
\hline & 11.1 Revisar e reescrever textos. & 11. Revisão e reescrita de textos. \\
\hline
\end{tabular}




\section{Habilidades e Conteúdos: 4ํㅗimestre}

\section{LÍNGUA PORTUGUESA $8 \cong$ ANO 4 ㅇ BIMESTRE}

\begin{tabular}{|c|c|c|}
\hline $\begin{array}{l}\text { Bloco de } \\
\text { conteúdo }\end{array}$ & Habilidades & Conteúdos \\
\hline 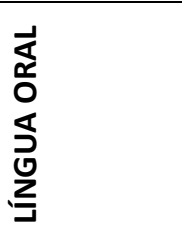 & $\begin{array}{l}\text { 1.1 Observar cartuns, charges, biografia, caricaturas e expressar } \\
\text { opiniões sobre os textos. } \\
\text { 1.2 Associar conteúdos com imagens. } \\
\text { 1.3 Relacionar os textos com acontecimentos do cotidiano. } \\
\text { 1.4 Reconhecer a intencionalidade do autor. }\end{array}$ & $\begin{array}{l}\text { 1. Cartum, charge, biografia e caricatura - linguagem } \\
\text { verbal e visual; características e elementos dos } \\
\text { gêneros; intertextualidade e interdiscursividade. }\end{array}$ \\
\hline 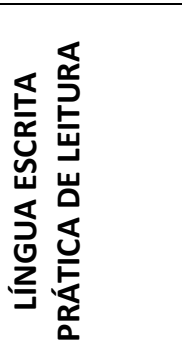 & $\begin{array}{l}\text { 2.1 Identificar as características do gênero. } \\
\text { 2.2 Estabelecer relações entre o texto e os conhecimentos prévios. } \\
\text { 2.3 Relacionar os textos aos seus contextos de produção. } \\
\text { 2.4 Identificar características próprias de texto visual específico (cartum, } \\
\text { charge e caricatura). } \\
\text { 2.5 Comparar as linguagens visual e verbal de diferentes autores. } \\
\text { 2.6 Relacionar os textos ao seu contexto de produção e suporte de } \\
\text { circulação. } \\
\text { 2.7 Reconhecer marcas de intertextualidade e interdiscursividade presentes } \\
\text { no texto. }\end{array}$ & $\begin{array}{l}\text { 2. Cartum, charge, biografia e caricatura - linguagem } \\
\text { verbal e visual; características e elementos } \\
\text { constituintes do gênero; intertextualidade e } \\
\text { interdiscursividade. }\end{array}$ \\
\hline 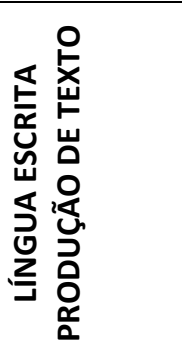 & $\begin{array}{l}\text { 3.1 Planejar o texto a partir de informações obtidas; } \\
\text { 3.2 Planejar a imagem relacionada à mensagem; } \\
\text { 3.3 Produzir o texto estruturando-o de acordo com o gênero e suas } \\
\text { características; } \\
\text { 3.4 Revisar o texto elaborado, antes da versão final. }\end{array}$ & $\begin{array}{l}\text { 3. Cartum, charge e caricatura - intertextualidade e } \\
\text { interdiscursividade; elementos visuais e verbais. }\end{array}$ \\
\hline \multirow{5}{*}{ 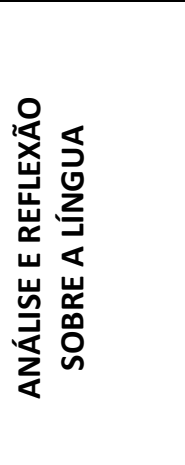 } & $\begin{array}{l}\text { 4.1 Compreender o emprego de palavras homônimas, homófonas e } \\
\text { homógrafas e suas diferenças de sentido na organização e construção de } \\
\text { orações. }\end{array}$ & $\begin{array}{l}\text { 4. Fonética - palavras homógrafas, homófonas e } \\
\text { homônimas. }\end{array}$ \\
\hline & $\begin{array}{l}\text { 5.1 Reconhecer as conjunções coordenativas e os pronomes relativos e suas } \\
\text { relações de sentido na oração. } \\
5.2 \text { Identificar e compreender o processo de formação de palavras, radicais e } \\
\text { afixos. }\end{array}$ & $\begin{array}{l}\text { 5. Morfologia - conjunções coordenativas; pronomes } \\
\text { relativos; estrutura das palavras: radicais e afixos. }\end{array}$ \\
\hline & $\begin{array}{l}\text { 6.1 Empregar corretamente os pronomes oblíquos. } \\
6.2 \text { Identificar e classificar os períodos compostos por coordenação. }\end{array}$ & $\begin{array}{l}\text { 6. Sintaxe - colocação pronominal: próclise, mesóclise } \\
\text { e ênclise; período composto por coordenação. }\end{array}$ \\
\hline & 7.1 Grafar corretamente as palavras. & 7. Ortografia - uso de G e J; X e CH. \\
\hline & 8.1 Revisar e reescrever textos. & 8. Revisão e reescrita de textos. \\
\hline
\end{tabular}




\section{Avaliação}

Portaria SE 04/09, de 06 de maio de 2009 que dispõe sobre a sistemática de avaliação para as escolas de ensino fundamental da Rede Municipal de Ensino. 
ANEXO B - Plano de Ensino do $9^{\circ}$ ano

PLANO DE ENSINO ANUAL

\begin{tabular}{|l|l|}
\hline Disciplina & Língua Portuguesa \\
\hline Professores & \\
\hline Ano/ Série & 9o Ano/8a Série \\
\hline Carga Horária & \\
\hline Ano letivo & \\
\hline
\end{tabular}

Justificativa da disciplina 
Habilidades e Conteúdos: 10 Bimestre

\section{LÍNGUA PORTUGUESA 9 ANO}

\begin{tabular}{|c|c|c|}
\hline $\begin{array}{l}\text { Bloco de } \\
\text { conteúdo }\end{array}$ & Habilidades & Conteúdos \\
\hline 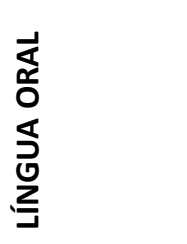 & $\begin{array}{l}\text { 1.1 Compreender o sentido e a intencionalidade do texto. } \\
\text { 1.2 Comentar e justificar opiniões. } \\
\text { 1.3 Reconhecer características dos gêneros. } \\
\text { 1.4 Respeitar as variantes linguísticas. } \\
\text { 1.5 Confrontar diferentes impressões e interpretações sobre o modo de } \\
\text { escrever do autor. }\end{array}$ & $\begin{array}{l}\text { 1. Contos, crônicas e biografias - características dos } \\
\text { gêneros; elementos constituintes e estruturas. }\end{array}$ \\
\hline 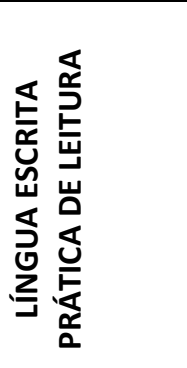 & $\begin{array}{l}\text { 2.1 Identificar as características dos gêneros. } \\
\text { 2.2 Relacionar texto ao seu contexto de produção e suporte de circulação } \\
\text { original. } \\
\text { 2.3 Estabelecer relações entre os textos e os conhecimentos prévios. } \\
\text { 2.4 Compreender o papel do conflito gerador nos episódios narrados. } \\
\text { 2.5 Recuperar informações explícitas e inferir informações implícitas. } \\
\text { 2.6 Interpretar a posição do autor, o ponto de vista das personagens e do } \\
\text { narrador. } \\
\text { 2.7 Conhecer a biografia e a alguns trabalhos do autor como sugestão de } \\
\text { leitura. }\end{array}$ & $\begin{array}{l}\text { 2. Contos e crônicas - elementos e estrutura dos } \\
\text { gêneros; conotação e denotação; biografias de } \\
\text { autores. }\end{array}$ \\
\hline 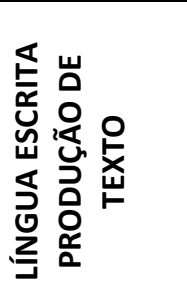 & $\begin{array}{l}\text { 3.1 Planejar textos respeitando as características e as estruturas dos } \\
\text { gêneros. } \\
\text { 3.2 Produzir textos estruturando-os de acordo com o gênero. } \\
\text { 3.3 Revisar e reescrever os textos de acordo com a análise e reflexão sobre a } \\
\text { língua. }\end{array}$ & 3. Contos e crônicas. \\
\hline \multirow{6}{*}{ 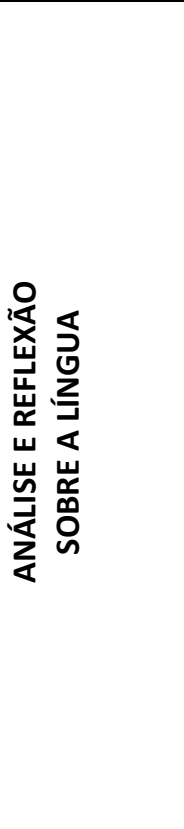 } & $\begin{array}{l}\text { 4.1 Reconhecer e utilizar corretamente as regras de acentuação do acordo } \\
\text { ortográfico. }\end{array}$ & 4. Fonética: regras de acentuação. \\
\hline & $\begin{array}{l}\text { 5.1 Identificar a estrutura das palavras - radicais e afixos. } \\
5.2 \text { Conhecer o processo de formação das palavras - derivação e } \\
\text { composição. }\end{array}$ & $\begin{array}{l}\text { 5. Morfologia - estrutura das palavras: radical e afixo; } \\
\text { processo de formação das palavras - derivação e } \\
\text { composição. }\end{array}$ \\
\hline & $\begin{array}{l}\text { 6.1 Reconhecer as pessoas do discurso e examinar o uso de primeira ou } \\
\text { terceira pessoa de acordo com a intenção da escrita. } \\
\text { 6.2 Utilizar corretamente os sinais de pontuação. } \\
\text { 6.3 Conhecer e utilizar adequadamente as desinências nominais e verbais. } \\
\text { 6.4 Reconhecer e diferenciar o período simples do período composto por } \\
\text { coordenação. } \\
\text { 6.5 Reconhecer o valor semântico das orações coordenadas. }\end{array}$ & $\begin{array}{l}\text { 6. Sintaxe - tipos de discurso; sinais de pontuação; } \\
\text { desinência verbal e nominal; período simples e período } \\
\text { composto por coordenação. }\end{array}$ \\
\hline & $\begin{array}{l}7.1 \text { Empregar corretamente palavras no sentido denotativo e conotativo de } \\
\text { acordo com o contexto. }\end{array}$ & 7. Semântica - Conotação e denotação. \\
\hline & $\begin{array}{l}\text { 8.1 Refletir sobre o uso da linguagem, utilizar adequadamente os conceitos } \\
\text { adquiridos e estabelecer diferenças entre palavras e ideias parecidas. }\end{array}$ & $\begin{array}{l}\text { 8. Ortografia: Uso de a par e ao par; ao encontro e de } \\
\text { encontro. }\end{array}$ \\
\hline & 9.1 Revisar e reescrever textos. & 9. Revisão e reescrita de textos. \\
\hline
\end{tabular}


Habilidades e Conteúdos: 2ํㅗㄹ Bimestre

\section{LÍNGUA PORTUGUESA $9^{\circ}$ ANO}

\begin{tabular}{|c|c|c|}
\hline & Habilidades & Conteúdos \\
\hline \multirow{2}{*}{ 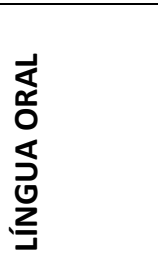 } & $\begin{array}{l}\text { 1.1 Comparar textos e expressar opiniões. } \\
\text { 1.2 Expressar opinião, expor argumentos pertinentes ao gênero e defender } \\
\text { oralmente seu ponto de vista. }\end{array}$ & $\begin{array}{l}\text { 1. Carta argumentativa - estrutura e elementos } \\
\text { constituintes do gênero; elementos da comunicação: } \\
\text { emissor, destinatário, mensagem, canal, contexto. }\end{array}$ \\
\hline & $\begin{array}{l}\text { 2.1 Perceber a intenção do texto publicitário. } \\
\text { 2.2 Reconhecer a linguagem e os recursos persuasivos do gênero. } \\
\text { 2.3 Realizar apresentação oral adequada à situação de interlocução. }\end{array}$ & $\begin{array}{l}\text { 2. Texto publicitário - elementos constituintes do gênero; } \\
\text { objetivos e recursos da linguagem. }\end{array}$ \\
\hline \multirow{2}{*}{ 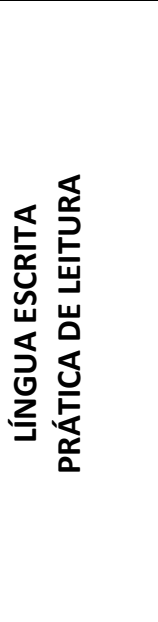 } & $\begin{array}{l}\text { 3.1 Identificar as características do gênero. } \\
\text { 3.2 Identificar elementos internos específicos do gênero: introdução com a } \\
\text { tese, apresentação de dados, nova tese com opinião do autor. } \\
\text { 3.3 Relacionar o texto ao seu contexto de produção e suporte de circulação } \\
\text { original. } \\
\text { 3.4 Estabelecer relações entre o texto e seus conhecimentos prévios. } \\
\text { 3.5 Interpretar a posição do autor em relação ao texto. } \\
\text { 3.6 Observar e analisar as características da situação de argumentação } \\
\text { descrevendo-as. } \\
\text { 3.7 Inferir informações implícitas. }\end{array}$ & $\begin{array}{l}\text { 3. Carta argumentativa - estrutura e elementos } \\
\text { constituintes do gênero; elementos da comunicação: } \\
\text { emissor, destinatário, mensagem, canal, contexto. }\end{array}$ \\
\hline & $\begin{array}{l}\text { 4.1 Relacionar texto ao seu contexto de produção e suporte de circulação } \\
\text { original; } \\
4.2 \text { Estabelecer relações entre o texto escrito (verbal) e os recursos gráficos } \\
\text { (visuais). } \\
4.3 \text { Identificar a posição e intenção do autor em relação ao texto. } \\
4.4 \text { Analisar criticamente os conteúdos das mensagens identificando os } \\
\text { valores e as conotações que veiculam. }\end{array}$ & $\begin{array}{l}\text { 4. Texto publicitário - elementos constituintes do gênero; } \\
\text { objetivos e recursos da linguagem. }\end{array}$ \\
\hline \multirow{2}{*}{ 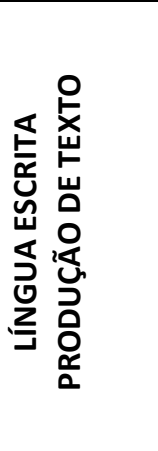 } & $\begin{array}{l}\text { 5.1 Planejar o texto a partir de informações e opiniões. } \\
\text { 5.2 Produzir texto estruturando-o de acordo com o gênero. } \\
\text { c.3 Expressar sua opinião através da escrita e defender seu ponto de vista } \\
\text { com argumentos persuasivos. } \\
\text { 5.4 Reconhecer a clareza no texto e utilizar articuladores sintáticos } \\
\text { adequados ao contexto da situação comunicativa. }\end{array}$ & 5. Produção de carta opinativa. \\
\hline & $\begin{array}{l}\text { 6.1 Compreender o sentido e a intencionalidade do texto. } \\
\text { 6.2 Produzir mensagens próprias, interagindo com o meio. } \\
\text { 6.3 Construir estratégias publicitárias e utilizá-las como recursos persuasivos } \\
\text { na construção do texto. } \\
\text { 6.4 Produzir o texto fazendo uso da coerência e de mecanismos de coesão } \\
\text { próprios do gênero. }\end{array}$ & 6. Produção de textos publicitários. \\
\hline \multirow{5}{*}{ 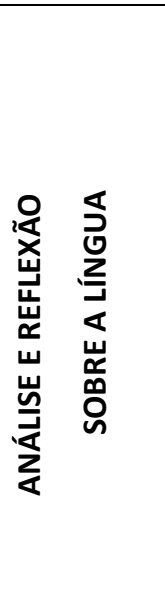 } & $\begin{array}{l}\text { 7.1 Refletir sobre o uso da linguagem, utilizar adequadamente os conceitos } \\
\text { adquiridos e estabelecer diferenças entre palavras e ideias parecidas. }\end{array}$ & 7. Semântica - uso dos porquês; onde / aonde. \\
\hline & $\begin{array}{l}\text { 8.1 Examinar e utilizar corretamente as formas nominais e o modo } \\
\text { imperativo de acordo com a intenção do texto. } \\
8.2 \text { Identificar as conjunções subordinadas e suas funções dentro da oração. }\end{array}$ & $\begin{array}{l}\text { 8. Morfologia - verbos: tempos, modos e formas nominais } \\
\text { (imperativo); conjunções. }\end{array}$ \\
\hline & $\begin{array}{l}\text { 9.1 Fazer a concordância nominal e verbal de acordo com a norma culta da } \\
\text { língua. } \\
\text { 9.2 Construir conceitos referentes ao período composto por subordinação. } \\
\text { 9.3 Classificar as orações subordinadas estabelecendo relação de sentido } \\
\text { entre os períodos. }\end{array}$ & $\begin{array}{l}\text { 9. Sintaxe - concordância nominal e concordância verbal; } \\
\text { período Composto por subordinação; orações subordinadas } \\
\text { substantivas. }\end{array}$ \\
\hline & 10.1 Grafar corretamente as palavras. & 10. Ortografia - uso de G e J; S, SS, SC, X e XC. \\
\hline & 11.1 Revisar e reescrever textos. & 11. Revisão e reescrita de textos. \\
\hline
\end{tabular}




\section{LÍNGUA PORTUGUESA $9^{\circ}$ ANO}

\begin{tabular}{|c|c|c|}
\hline $\begin{array}{l}\text { Bloco de } \\
\text { conteúdo }\end{array}$ & Habilidades & Conteúdos \\
\hline 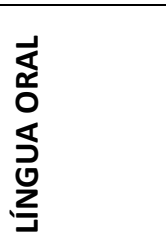 & $\begin{array}{l}\text { 1.1 Trocar impressões e confrontar opiniões. } \\
\text { 1.1 } 1.2 \text { Reconhecer argumentações que sustentam a opinião do autor. } \\
1.2 \quad 1.3 \text { Identificar o posicionamento do autor e descrever seu } \\
\text { posicionamento, seu ponto de vista sobre o tema tratado. } \\
1.3 \quad 1.4 \text { Escolher e classificar argumentos que sejam favoráveis ou } \\
\text { contrários à defesa do ponto de vista. } \\
1.4 \quad 1.5 \text { Respeitar opiniões contrárias ao seu ponto de vista. }\end{array}$ & 1. Romance/ Resenha crítica - dissertação expositiva. \\
\hline 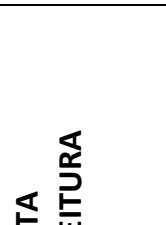 & $\begin{array}{l}\text { 2.1 Identificar as características do gênero do texto. } \\
2.2 \text { Estabelecer relações entre o texto e os conhecimentos prévios. } \\
2.3 \text { Identificar o posicionamento do autor e os argumentos que sustentam o } \\
\text { ponto de vista. } \\
2.4 \text { Inferir o uso de palavras do texto com sentido conotativo. } \\
2.5 \text { Comparar obras e reconhecer a intertextualidade. }\end{array}$ & $\begin{array}{l}\text { 2. Romance/ Resenha crítica - resumo; análise da obra; } \\
\text { temática; conceitos de valor; comparação de obras e } \\
\text { autores; intertextualidade. }\end{array}$ \\
\hline 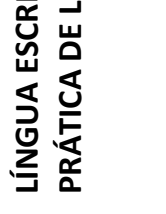 & $\begin{array}{l}\text { 3.1 Identificar as características do gênero. } \\
\text { 3.2 Estabelecer relações entre o texto e conhecimentos prévios. } \\
\text { 3.3 Comparar opiniões e argumentos que sustentam o texto de acordo com } \\
\text { a situação de comunicação. }\end{array}$ & $\begin{array}{l}\text { 3. Dissertação expositiva - pesquisa, exposição e } \\
\text { interpretação de ideias, posicionamento baseado em } \\
\text { argumentos; temática; referências bibliográficas; } \\
\text { referências do autor etc. }\end{array}$ \\
\hline 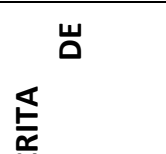 & $\begin{array}{l}\text { 4.1 Estruturar o texto de acordo com o gênero. } \\
\text { 4.2 Produzir texto fazendo uso dos mecanismos de coesão e coerência. } \\
\text { 4.3 Escrever parágrafos argumentativos utilizando conhecimentos } \\
\text { adquiridos de acordo com o contexto da situação de comunicação. }\end{array}$ & 4. Resenha crítica de filmes, artigos e livros. \\
\hline 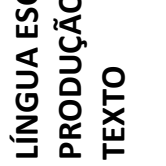 & $\begin{array}{l}\text { 5.1 Escrever texto expressando suas ideias e seu ponto de vista apoiados em } \\
\text { argumentos. } \\
5.2 \text { Revisar e reescrever texto de acordo com os conteúdos linguísticos } \\
\text { estudados. }\end{array}$ & $\begin{array}{l}\text { 5. Dissertação expositiva sobre temas abordados em } \\
\text { filmes, artigos e livros. }\end{array}$ \\
\hline \multirow{6}{*}{ 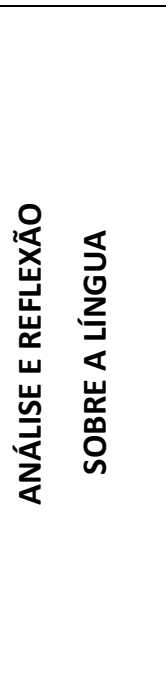 } & $\begin{array}{l}\text { 6.1 Acentuar corretamente palavras com os ditongos abertos "ei e oi" } \\
\text { seguindo as regras do acordo ortográfico. }\end{array}$ & $\begin{array}{l}\text { 6. Fonética - estudo das regras de acentuação dos } \\
\text { ditongos abertos "ei e oi". }\end{array}$ \\
\hline & 7.1 Conhecer as conjunções subordinadas adjetivas. & 7. Morfologia - conjunções subordinativas adjetivas. \\
\hline & $\begin{array}{l}\text { 8.1 Diferenciar o período simples do período composto. } \\
8.2 \text { Construir conceitos linguísticos referentes às orações subordinadas } \\
\text { adjetivas e suas relações de sentido. } \\
8.3 \text { Utilizar corretamente os pronomes oblíquos e a colocação pronominal } \\
\text { de acordo com a norma culta. }\end{array}$ & $\begin{array}{l}\text { 8. Sintaxe - período composto; orações subordinadas } \\
\text { adjetivas; colocação pronominal. }\end{array}$ \\
\hline & 9.1 Grafar corretamente as palavras. & 9. Ortografia - uso de S, SS, SC, X, XC; uso de G e J. \\
\hline & $\begin{array}{l}\text { 10.1 Identificar e classificar as figuras de linguagem e sua função dentro do } \\
\text { texto. } \\
10.2 \text { Identificar os vícios de linguagem e reconhecer recursos estilísticos que } \\
\text { auxiliam na construção de um texto com qualidade. }\end{array}$ & $\begin{array}{l}\text { 10. Estilística - figuras de linguagem: figuras de palavras; } \\
\text { de construção; de pensamento; vícios de linguagem; } \\
\text { qualidades da boa linguagem. }\end{array}$ \\
\hline & 11.1 Revisar e reescrever textos. & 11. Revisão e reescrita de textos. \\
\hline
\end{tabular}


Habilidades e Conteúdos: 4ํㅗㄹ Bimestre

\section{LÍNGUA PORTUGUESA $9^{\circ}$ ANO}

\begin{tabular}{|c|c|c|}
\hline $\begin{array}{l}\text { Bloco de } \\
\text { conteúdo }\end{array}$ & Habilidades & Conteúdos \\
\hline \multirow{2}{*}{ 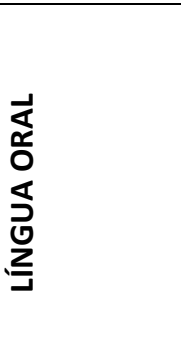 } & $\begin{array}{l}\text { 1.1 Compreender a intencionalidade do autor. } \\
\text { 1.2 Comentar e justificar opiniões. } \\
\text { 1.3 Analisar sequência de ações para um determinado resultado. } \\
\text { 1.4 Tirar conclusões a partir das ações. }\end{array}$ & $\begin{array}{l}\text { 1. Texto instrucional e prescritivo - manual de } \\
\text { instrução; bulas de remédio; receitas culinárias, } \\
\text { regulamentos, artigos de leis etc. }\end{array}$ \\
\hline & 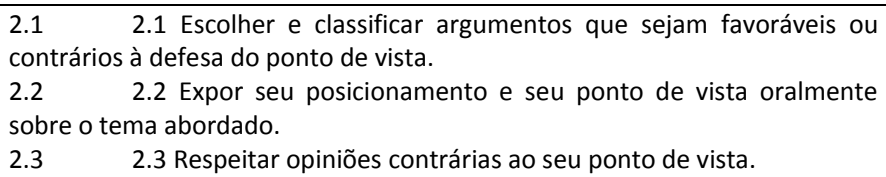 & $\begin{array}{l}\text { 2. Dissertação argumentativa - comparação de } \\
\text { textos. }\end{array}$ \\
\hline \multirow{2}{*}{ 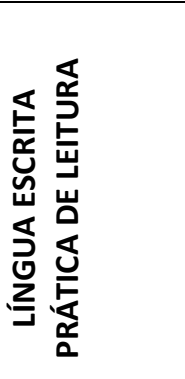 } & $\begin{array}{l}\text { 3.1 Reconhecer organização própria do gênero instrucional. } \\
\text { 3.2 Estabelecer relações entre o texto e os conhecimentos prévios. } \\
\text { 3.3 Relacionar texto ao seu contexto de produção e suporte de circulação } \\
\text { original. } \\
\text { 3.4 Comparar textos instrucionais com outros gêneros de textos e analisar as } \\
\text { diferenças quanto ao uso da linguagem denotativa, sua função e } \\
\text { importância no texto. }\end{array}$ & $\begin{array}{l}\text { 3. Texto instrucional e prescritivo - manual de } \\
\text { instrução; bulas de remédio; receitas culinárias, } \\
\text { regulamentos, artigos de leis etc. }\end{array}$ \\
\hline & $\begin{array}{l}\text { 4.1 Identificar as características do gênero. } \\
\text { 4.2 Estabelecer relações entre o texto e conhecimentos prévios. } \\
\text { 4.3 Comparar opiniões e argumentos que sustentam o texto de acordo com } \\
\text { a situação de comunicação e o ponto de vista do autor. }\end{array}$ & $\begin{array}{l}\text { 4. Dissertação argumentativa }- \text { pesquisa, } \\
\text { interpretação de ideias, temática; referências do } \\
\text { autor etc. }\end{array}$ \\
\hline \multirow{2}{*}{ 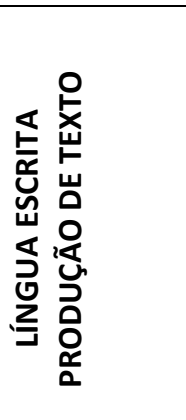 } & $\begin{array}{l}\text { 5.1 Planejar textos de acordo com o gênero proposto. } \\
\text { 5.2 Organizar sequência de ações para produção de texto com orientação. } \\
\text { 5.3 Produzir texto claro, coeso e coerente tendo em vista um objetivo } \\
\text { específico. } \\
\text { 5.4 Comparar textos instrucionais e registrar conclusões. }\end{array}$ & $\begin{array}{l}\text { 5. Texto instrucional - elementos e estrutura do } \\
\text { gênero. } \\
\text { 1. }\end{array}$ \\
\hline & $\begin{array}{l}\text { 6.1 Estruturar seu texto com base em argumentos favoráveis ou contrários } \\
\text { em defesa de seu ponto de vista. } \\
\text { 6.2 Manter a estrutura e as características do gênero dissertação } \\
\text { argumentativa. } \\
\text { 6.3 Utilizar conceitos adquiridos na análise e reflexão sobre a língua e } \\
\text { elementos de coesão e coerência. }\end{array}$ & 6. Dissertação argumentativa - produção de texto. \\
\hline \multirow{3}{*}{ 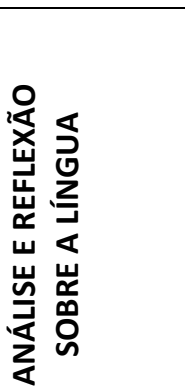 } & $\begin{array}{l}7.1 \text { Reconhecer as conjunções subordinativas adverbiais e suas funções } \\
\text { dentro das orações. }\end{array}$ & $\begin{array}{l}\text { 7. Morfologia - conjunções subordinativas } \\
\text { adverbiais. }\end{array}$ \\
\hline & $\begin{array}{l}\text { 8.1 Analisar as orações subordinadas adverbiais e a suas relações de sentido } \\
\text { na oração. } \\
\text { 8.2 Refletir sobre o uso da linguagem e utilizar corretamente a regência } \\
\text { verbal. } \\
\text { 8.3 Refletir sobre o uso da linguagem e utilizar corretamente a regência } \\
\text { nominal. } \\
\text { 8.4 Utilizar corretamente a crase e compreender a sua função na oração. }\end{array}$ & $\begin{array}{l}\text { 8. Sintaxe - orações subordinadas adverbiais; } \\
\text { regência verbal; regência nominal; uso da crase. }\end{array}$ \\
\hline & 9.1 Revisar e reescrever textos. & 9. Revisão e reescrita de textos. \\
\hline
\end{tabular}


Portaria SE 04/09, de 06 de maio de 2009 que dispõe sobre a sistemática de avaliação para as escolas de ensino fundamental da Rede Municipal de Ensino.

\section{Referencial Teórico}


ANEXO C - Grade curricular da escola de período integral

\section{Quadro Curricular 2011}

Ensino Fundamental

EMEF:

CODIGO CIE:

CEP:

ENDEREÇO:

BAIRRO:

E-mail:

CURSO:

ANO:

1800HORAS/ ANO

40 SEMANAS COM 40 HORAS/AULA DE 50'

200 dias letivos com 09 horas diárias de permanência do aluno na escola

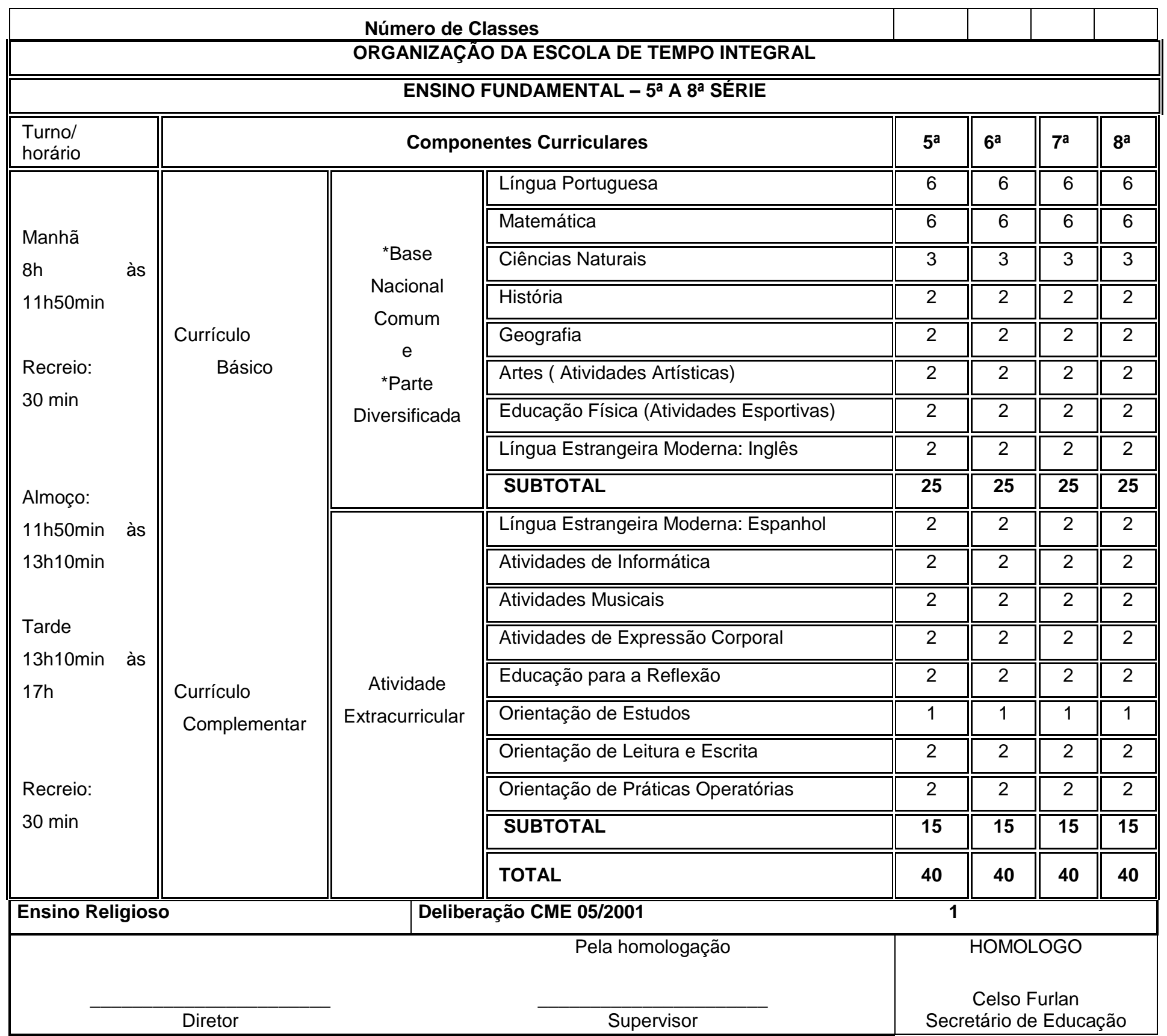

